NBER WORKING PAPER SERIES

\title{
TAX CUTS FOR WHOM? HETEROGENEOUS EFFECTS OF INCOME TAX CHANGES ON GROWTH AND EMPLOYMENT
}

\author{
Owen M. Zidar \\ Working Paper 21035 \\ http://www.nber.org/papers/w21035 \\ NATIONAL BUREAU OF ECONOMIC RESEARCH \\ 1050 Massachusetts Avenue \\ Cambridge, MA 02138 \\ March 2015 \\ Revised February 2017
}

I am grateful to Alan Auerbach, Dominick Bartelme, Alex Bartik, Marianne Bertrand, David Card, Gabe Chodorow-Reich, Austan Goolsbee, Ben Keys, Pat Kline, Attila Lindner, Zachary Liscow, Neale Mahoney, Atif Mian, John Mondragon, Enrico Moretti, Matt Notowidigdo, Christina Romer, David Romer, Jesse Rothstein, Emmanuel Saez, Jim Sallee, Andrew Samwick, Amir Sufi, Laura Tyson, Johannes Wieland, Dan Wilson, Danny Yagan, and Eric Zwick for helpful comments and Dan Feenberg for generous help with TAXSIM. I am especially thankful to Amir Sufi as well as Marianne Bertrand and Adair Morse for generously sharing data with me. This project grew out of an undergraduate research project that I worked on with Daniel Cohen, and I am grateful to him and Jim Feyrer for input on the paper at its inception. Stephanie Kestelman, Stephen Lamb, Francesco Ruggieri, Karthik Srinivasan, and John Wieselthier provided excellent research assistance. This work is supported by the Kathryn and Grant Swick Faculty Research Fund at the University of Chicago Booth School of Business. The latest version of this paper can always be found at http://faculty.chicagobooth.edu/owen.zidar/. The views expressed herein are those of the author and do not necessarily reflect the views of the National Bureau of Economic Research.

NBER working papers are circulated for discussion and comment purposes. They have not been peer-reviewed or been subject to the review by the NBER Board of Directors that accompanies official NBER publications.

(C) 2015 by Owen M. Zidar. All rights reserved. Short sections of text, not to exceed two paragraphs, may be quoted without explicit permission provided that full credit, including () notice, is given to the source. 
Tax Cuts For Whom? Heterogeneous Effects of Income Tax Changes on Growth and Employment Owen M. Zidar

NBER Working Paper No. 21035

March 2015, Revised February 2017

JEL No. E32,E62,H2,H20,H31,N12

\section{ABSTRACT}

This paper investigates how tax changes for different income groups affect aggregate economic activity. I construct a measure of who received (or paid for) tax changes in the postwar period using tax return data from NBER's TAXSIM. I aggregate each tax change by income group and state. Variation in the income distribution across U.S. states and federal tax changes generate variation in regional tax shocks that I exploit to test for heterogeneous effects. I find that the positive relationship between tax cuts and employment growth is largely driven by tax cuts for lower-income groups, and that the effect of tax cuts for the top $10 \%$ on employment growth is small.

Owen M. Zidar

University of Chicago

Booth School of Business

5807 South Woodlawn Avenue

Chicago, IL 60637

and NBER

owen.zidar@chicagobooth.edu 
There are two ideas of government. There are those who believe that if you just legislate to make the well-to-do prosperous, that their prosperity will leak through on those below. The Democratic idea has been that if you legislate to make the masses prosperous their prosperity will find its way up and through every class that rests upon it.

-William Jennings Bryan (July, 1896)

The consequences of changing tax policy for different groups are fiercely debated. Some policy makers maintain that tax changes for high-income earners "trickle down" and are the most effective way to affect prosperity. They argue that higher marginal tax rates for top-income taxpayers lead to large distortions in labor supply, investment, and hiring, so tax cuts for top-income taxpayers most effectively increase aggregate economic activity. Others, however, contend the opposite. They argue that lower-income groups have higher marginal propensities to consume and disincentives to work from means-tested benefits, so tax cuts for lower-income groups generate sizable consumption and labor supply responses, and thereby, more overall activity. Do tax changes for high-income earners "trickle down?" Would these effects be larger if the tax changes were less targeted at the top?

Variation in income tax policy in the U.S. can help us answer these questions and inform the debate on "trickle down" versus "bottom up" economics. In the early 1980s and 2000s, the largest tax cuts as a share of income went to top-income taxpayers. In the early 1990s, topincome earners faced tax increases while taxpayers with low to moderate incomes received tax cuts. This paper investigates how the composition of tax changes affects subsequent economic activity. The possibility that the impact of tax changes depends not only on how large the changes are, but also on how they are distributed has important implications for understanding macroeconomic activity, designing countercyclical policy, and assessing the consequences of many redistributive policies.

The main contribution of this paper is to use new data and a novel source of variation to quantify the importance of the distribution of tax changes for their overall impact on economic activity. I find that tax cuts that go to high-income taxpayers generate less growth than similarly-sized tax cuts for low and moderate income taxpayers. In fact, the positive relationship between tax cuts and employment growth is largely driven by tax cuts for lower-income groups and the effect of tax cuts for the top $10 \%$ on employment growth is small.

Establishing this result requires overcoming three empirical difficulties. First, many tax changes happen in response to current or expected economic conditions. Second, tax changes for low- and high-income taxpayers often occur at the same time, so separately identifying the 
effects of low- and high-income tax cuts is difficult. Third, the number of data points and tax changes in the postwar period is limited.

This paper uses variation in the regional impact of national tax shocks to overcome these empirical difficulties. Variation in the income distribution across U.S. states lead to heterogeneous regional impacts of federal income tax changes. For instance, Connecticut, whose share of top-income taxpayers is nearly twice that of the typical state, faced relatively larger shocks to high-income earners after the Omnibus Budget Reconciliation Act of 1993, which raised topincome tax rates. I focus on a subset of federal tax changes that are not related to the current state of the economy according to the classification approach of Romer and Romer (2010). ${ }^{1}$ The interaction of (1) regional heterogeneity and (2) exogenous federal tax changes produces plausibly exogenous regional tax shocks, differently-sized shocks for different income groups, and more data on the economic consequences of tax changes.

I use individual tax return data from NBER's TAXSIM to quantify these tax shocks. For each tax change, I construct a measure of who received (or paid for) the tax change. The measure of the tax change is based on three things for every individual return: income and deductions in the year prior to an exogenous tax change, the old tax schedule, and the new tax schedule. For example, consider a taxpayer in 1992 whose income was $\$ 180,000$. Based on her 1992 income and deductions, she would have paid $\$ 50,500$ in taxes according to the old 1992 tax rate schedule and $\$ 54,000$ according to the new 1993 tax rate schedule. My measure assigns her a $\$ 3,500$ tax increase for 1993. I use the prior year's tax data to avoid conflating behavioral responses and measured changes in tax liabilities. I then aggregate these mechanical tax changes for each taxpayer in a state by income group, such as the bottom $90 \%$ and top $10 \%$ of national AGI respectively.

With these year-state-income group level tax shock measures, I investigate how responsive employment growth and economic activity are to tax shocks for different income groups. I estimate the dynamic effects of tax changes for different groups using event studies, distributed lag models, and more parsimonious two-year changes. Since federal tax changes differ in their progressivity, the tax shock from a given federal tax change differs regionally based on each

\footnotetext{
${ }^{1}$ They use the historical record (such as congressional records, economic reports and presidential speeches) to identify tax changes that were taken for more exogenous reasons such as pursuing long run growth or deficit reduction. Doing so reinforces my ability to overcome endogeneity concerns. Appendix Table A1 lists each tax change and how it is classified.
} 
location's income distribution. These regional differences in tax shocks enable me to identify the effects of tax shocks for both low- and high-income groups. For example, I identify the impact of high-income tax changes by comparing the responsiveness of employment growth in states like Connecticut to responsiveness in states with less exposure to high-income shocks. The empirical analysis has three components: (1) evidence of heterogeneous effects, (2) research design validation, (3) mechanisms and discussion.

First, I find that state employment growth and economic activity are substantially more responsive to tax shocks for lower-income groups than to equally-sized tax shocks for top earners. In particular, a $1 \%$ of state GDP tax cut for the bottom $90 \%$ results in roughly 3.4 percentage points of employment growth over a two-year period. The corresponding estimate for the top $10 \%$ is 0.2 percentage points and is statistically insignificant. Other measures of state economic activity, such as state GDP, payrolls, and net earnings, respond similarly, in that they are very responsive to tax changes for the bottom $90 \%$ and unresponsive to tax changes for the top $10 \%$.

Second, I provide several pieces of evidence to support the validity of these estimates. I build and use new state-level microsimulation models of social insurance programs (AFDC, TANF, SNAP, SSI, and Medicaid) to show that the impacts of tax changes for lower-income groups do not reflect policy changes in social insurance programs. Event study evidence shows that tax shocks are not disproportionately favoring states that are doing poorly relative to how fast they normally grow. Similarly, differential state cyclicality as well as contemporaneous oil price shocks, interest rate shocks, or regional trends are not driving the results.

Third, in terms of mechanisms, I show how tax changes for different groups impact labor market outcomes and consumption. Tax changes for the bottom $90 \%$ have much greater impact on both the extensive margin and intensive margin of labor supply than tax changes for the top $10 \%$. Specifically, a $1 \%$ of state GDP tax increase for the bottom $90 \%$ lowers labor force participation rates by 3.5 percentage points and hours by roughly $2 \%$. Tax changes of the same size for the top $10 \%$ have no detectable impact on these margins. State-level consumption also shows larger impacts for bottom $90 \%$ tax changes. These estimates on labor market outcomes and consumption are reduced-form effects on equilibrium outcomes that reflect changes in both changes in supply and demand. I find that real wages increase after tax changes for lowerincome groups. While the estimates are imprecise, they suggest that labor supply responses are an important mechanism for the results. 
The empirical literature on these mechanisms - consumption and labor supply - is consistent with the possibility of heterogeneous aggregate effects of tax changes. One strand of evidence relates to heterogeneous consumption responses. ${ }^{2}$ Many studies provide evidence that lowerincome households tend to have higher marginal propensities to consume (McCarthy, 1995; Parker, 1999; Dynan et al., 2004; Johnson et al., 2006; Jappelli and Pistaferri, 2010; Parker et al., 2013). ${ }^{3}$ A second strand of evidence relates to tax policy and labor supply responses of different income groups. On the extensive margin for lower-income groups, Eissa and Liebman (1996) and Meyer and Rosenbaum (2001) show that the Earned Income Tax Credit has strongly increased labor force participation. ${ }^{4}$ For high-income earners, there is some evidence that the costs of raising taxes on top-income taxpayers in terms of labor supply and other margins may be limited (Saez et al., 2012; Romer and Romer, 2014) and largely reflect shifting in the timing or form of income (Goolsbee, 2000; Auerbach and Siegel, 2000). By focusing on the overall impacts of tax changes for different groups, this paper not only incorporates the effects of heterogeneous consumption responses, but also provides evidence on the heterogeneous effects of supply side policies that often do not assess the efficacy of tax changes for low- versus high-income groups.

The estimates in this paper build on the regional multiplier literature, which was recently surveyed by Ramey (2011). In particular, the empirical approach in this paper resembles that of Nakamura and Steinsson (2014), but for taxes (with heterogeneity) rather than government spending. ${ }^{5}$ This regional approach complements the approach of Mertens and Ravn (2013) who

\footnotetext{
${ }^{2}$ Many macro papers, which often have consumption responses as a key channel, also support the notion that heterogeneity matters in the context of fiscal policy. Monacelli and Perotti (2011) use an incomplete markets model with borrowing constraints to show that lump sum redistribution from savers to borrowers is expansionary when nominal prices are sticky. The main intuition is that while both borrowers and savers optimize inter-temporally, redistribution to borrowers also relaxes their borrowing constraint and results in a level of consumption that exceeds the amount that savers reduced their consumption. This higher level of aggregate consumption raises output and employment. Similarly, Heathcote (2005) finds that temporary tax cuts can have large real effects in simulated models with heterogeneous agents and incomplete markets. Galí et al. (2007) show that macro models with some cash-on-hand agents and sticky prices do a better job explaining observed aggregate consumption patterns than representative-agent models.

${ }^{3}$ Note that not all papers, e.g., Shapiro and Slemrod (1995), find significant differences in spending responses as a function of income. More broadly, Chetty et al. (2014) estimate that approximately $85 \%$ of individuals are rule-of-thumb spenders. Saez and Zucman (2016) also show total savings among the bottom $90 \%$ is roughly zero and has been flat since the 1980s.

${ }^{4}$ While evidence based on bunching (Heckman, 1983; Saez, 2010) suggests that intensive margin responses are small, other work, such as Kline and Tartari (2016), provides evidence that tax policy changes can lead to nontrivial intensive margin responses among low-income groups. Kosar and Moffitt (2016) provide evidence on the cumulative marginal tax rates of low-income households.

${ }^{5}$ See Suárez Serrato and Wingender (2011) for a paper estimating how high- and low-skilled workers respond to different types of government spending shocks. Chodorow-Reich et al. (2012) and Hausman (2016) use similar methods to analyze two important fiscal policy episodes - Medicaid payments to states in the Great Recession
} 
investigate differences for personal income and corporate taxes as well as Mertens (2013) for top-income groups using a time series approach with national data on tax rates. Constructing a new measure of changes in tax liabilities based on micro tax return data also contributes to this literature because measurement error can partly explain large differences in the estimated effects of fiscal policy (Mertens and Ravn, 2014). In addition, the regional approach provides more power and variation in tax shocks for different groups, which enables me to separate and identify their effects on economic activity.

\section{Data on Tax Changes and Economic Activity}

\section{$1.1 \quad$ Tax Data}

This section describes how I construct a national time-series of tax changes by income group from 1950-2011. The following section then shows how this national series is distributed across U.S. states.

\subsubsection{National Tax Changes by Income Group}

I use tax measures from NBER when possible and rely on the Statistics of Income (SOI) tables to calculate changes before $1960 .{ }^{6}$ To calculate tax changes occurring after 1960, I use NBER's Tax Simulator TAXSIM, which is a program that calculates individual tax liabilities for every annual tax schedule since 1960 and stores a large sample of actual tax returns. I construct my measure of tax changes by comparing each individual's income and payroll tax liabilities in the year preceding a tax change to what their tax liabilities would have been if the new tax schedule had been applied. For instance, consider the 1993 Omnibus Budget Reconciliation Act. For every taxpayer, my measure subtracts how much she paid in 1992 from how much she would have paid in 1992 if the 1993 tax schedule had been in place. ${ }^{7}$ When calculating tax liabilities, TAXSIM takes into account every individuals' deductions and credits and their treatment under both the 1992 and 1993 tax schedules, resulting in a highly detailed measure of the mechanical,

and payments to veterans in 1936, respectively. Important contributions also include Clemens and Miran (2012); Shoag (2010); Wilson (2012).

${ }^{6}$ See appendix A.1.1 for a description of how I calculate the four pre-NBER tax changes, which affected tax liabilities in 1948, 1950, 1954, and 1960. This approach is similar to that of Barro and Redlick (2011), who focus on marginal rate changes rather than tax liability changes.

${ }^{7}$ See appendix A.1.2 for a more detail on the 1993 example tax change calculation. 
policy-induced change in tax liability at the individual tax return level. ${ }^{8}$ After calculating a change in tax liability for each taxpayer, I collapse the data by averaging it for every income percentile of AGI.

Figure 1 shows the results for four recent, prominent tax changes. Based on this measure of tax changes, 1993 taxpayers below median AGI received a modest tax cut of less than one percent of AGI and only the highest-income taxpayers faced higher taxes. A similar pattern emerges in 1991 under George H.W. Bush. In contrast, high-income taxpayers received the largest cuts in 1982 and 2003 under Reagan and Bush, respectively.

To compute total changes in income and payroll taxes in a given year, I multiply the average change in liability for each percentile by the number of returns in that percentile and then sum up each percentile's aggregate tax changes to obtain total tax changes for the bottom $90 \%$ and top $10 \%$ groups. I define tax shocks as a share of GDP, i.e., $T_{t}^{g} \equiv \frac{\text { Tax Liability Change }{ }_{t}^{g}}{G D P_{t}}$, where Tax Liability Change $\mathrm{e}_{t}^{g}$ is the sum of mechanical changes in tax liability for those in income group $g \in\{$ Bottom 90, Top 10\} in year $t$. As a robustness check, I compare my measure, i.e., the sum of tax changes for the bottom $90 \%$ and top 10\%, to the Romer and Romer (2010) total tax change measure. They are quite similar. ${ }^{9}$ Differences between my aggregate measure and their measure are partially due to tax changes that did not affect income or payroll taxes, such as corporate income tax changes, and are defined accordingly: $T_{\text {NONINC }} \equiv T_{R O M E R}-\sum_{g} T_{t}^{g}$.

Exogenous tax changes occurred in thirty-one years of the postwar period. ${ }^{10}$ In exogenous years, the average income and payroll tax change was $-0.16 \%$ of GDP, or roughly $\$ 25$ billion in 2011 dollars. It was $-0.075 \%$ overall in the entire sample. On average, in exogenous years in which the top $10 \%$ taxpayers did not see a tax increase, the size of the tax cut for the bottom $90 \%$ and the top $10 \%$ was roughly the same size. In exogenous years in which the top $10 \%$ did see tax increases, the size of the tax increase as a share of output was an order of magnitude

\footnotetext{
${ }^{8}$ Note that this method avoids bracket creep issues in the period before the Great Moderation since the hypothetical tax schedule applies to the old tax form data. Since inflation has been low during the Great Moderation, measurement error induced by this approach (due to inflation indexing) is quite small in magnitude. Also, it is not obviously correct to weight old tax data by CPI since median income growth has stagnated. As such, adjusting for the mild inflation of the Great Moderation may exacerbate measurement error rather than reduce it.

${ }^{9}$ Appendix Figure A7 plots both series by year. The Romer tax change measure is at a quarterly frequency, so I sum their measure to construct an annualized version.

${ }^{10}$ Exogenous is defined as a year in which Romer and Romer (2010) show a nonzero tax change where more than half the revenue was from an exogenous change. Stricter definitions of exogenous, i.e., ways to categorize years in which there were both exogenous and endogenous changes occurring in that year, produced very similar results. For non-exogenous years, the tax change measure is set to zero. Appendix Table A1 lists exogenous tax changes used in this paper.
} 
larger for the top $10 \%$ than for the bottom $90 \%$. On average, tax changes have been negative for both groups, meaning that tax cuts as a share of output tend to be larger than tax increases as a share of output.

Panel A of Figure 2 shows how income and payroll taxes have changed by AGI quintile since 1960. There are a few notable features. First, tax changes for different income groups often happen simultaneously. ${ }^{11}$ Second, the magnitudes of tax changes for the top $10 \%$ are larger in share of output terms since their income share is large and has been increasing. Third, tax increases have been rare since the 1980s, especially on the bottom four quintiles. Fourth, the earlier tax increases on the bottom 90\% mostly came through payroll tax increases before 1980.

\subsubsection{State Tax Changes by Income Group}

National tax changes have disparate impacts across regions of the United States due to substantial variation in the income distribution across states. Panel B of Figure 2 shows the average share of taxpayers who have incomes in the top 10\% nationally from 1980-2007. Based on this measure, a taxpayer in Connecticut is roughly three times more likely to be in the top $10 \%$ than a taxpayer in Maine.

Similar to the national changes, I define state tax shocks as a share of state GDP, i.e., $T_{s, t}^{g} \equiv \frac{\text { Tax Liability Change } e_{s, t}^{g}}{G D P_{s, t}}$, where Tax Liability Change is the sum of mechanical changes in tax liability for all the residents in state $s$ and group $g$ in year $t$. Note that the income groups are defined on a national basis, so top 10\% means a taxpayer's adjusted gross income is in the top $10 \%$ of national taxpayers (as opposed to a measure relative to others in their state). I am able to aggregate by state since TAXSIM has a variable indicating the state of residence for nearly all tax returns. However, taxpayers with AGI above $\$ 200,000$ in nominal dollars have the state identifier removed in the IRS data. ${ }^{12}$ This data limitation causes the first measure of tax changes to be approximated within TAXSIM for very high incomes at the state level. ${ }^{13}$

\footnotetext{
${ }^{11}$ Based on Frisch and Waugh (1933) logic, a tax change that provides atypical changes to a given income group will influence estimates more strongly than proportionate tax changes. Appendix Figure A9 shows this point explicitly - years like 2003 provided disproportionately larger tax cuts to the top $10 \%$ given the size of the tax change for the bottom $90 \%$.

${ }^{12}$ In 1975 , the first year with state data available, the price level was roughly $25 \%$ of the 2010 level, so this cutoff amounts to roughly $\$ 800,000$ of AGI. Put another way, $\$ 200,000$ was between the $99.9 \%$ and $99.99 \%$ income cutoff in the 1975 AGI distribution. In 2010, an AGI of $\$ 200,000$ is still well above the $95^{\text {th }}$ income percentile (the cutoff is roughly $\$ 150,000$ ).

${ }^{13}$ Due to the $\$ 200,000$ censoring, I have to extrapolate part of the state shares for the top-income group. I determine the total number of income earners whose incomes exceed the $\$ 200,000$ cutoff every year and allocate
} 


\section{$1.2 \quad$ Non-Tax Data}

\subsubsection{Non-Tax Data at the State Level}

The main measures of economic activity are employment and income. I use two measures of employment - the employment-to-population ratio and the number of people employed. ${ }^{14} \mathrm{I}$ also use two measures of state income: state GDP and net earnings. Net earnings (which is state personal income less personal government transfers and dividends, interest, and rents) provides a measure of income that nets out components that are less related to regional tax shocks.

A limitation of the income measures, however, is that they are in nominal terms and converting them into real terms is difficult because state-level price indexes are imperfect. My preferred state price index is $P_{s, t}^{A C C R A}$, which is the average price index from the American Chamber of Commerce Researchers Association on cost of living in a state-year. It has been used in the local labor markets literature, e.g., Moretti (2013), to construct regional price indexes and is available for the full panel of states since 1980. I supplement this price index with $P_{s, t}^{M o r e t t i}$, which follows the approach from Moretti (2013) to create a local price index based on state house prices and national CPI. ${ }^{15}$

To better understand mechanisms, I also analyze several labor market outcomes from the Current Population Survey (CPS) at the state level: labor force participation, hours, wages, and real wages. ${ }^{16}$ I focus on labor force participation to analyze extensive margin responses, and on hours among full-time employed residents aged 25 to 60 to isolate intensive margin responses. Wages are wage income divided by hours among full-time workers. Finally, to remove the influence of compositional changes of labor market participants on average wages, I also construct composition-constant wages. ${ }^{17}$ Appendix A.2 provides additional detail on

them according to extrapolated state shares for that year. I assume that each state's share of the total number of U.S. income earners just below the cutoff (from $\$ 150,000$ to $\$ 200,000$ ) is the same as its share of national income earners whose incomes exceed $\$ 200,000$. Very little extrapolation is required in the early years, in which more than $99 \%$ of incomes fall below the censoring cutoff. In 2010, more than $95 \%$ of income earners still earned less than $\$ 200,000$.

${ }^{14}$ I use the Current Population Survey (CPS) to construct employment-to-population ratios, the Bureau of Labor Statistics (BLS) for employment, and Bureau of Economic Analysis (BEA) for GDP at the state level.

${ }^{15}$ Moretti (2013) uses a local price index based on rental payments and national CPI, but rental payments are only available in 1980, 1990, and the 2000s, so I use state house prices from FHFA in place of rental payments. Since house prices are asset prices that are forward-looking, I prefer the $P_{s, t}^{A C C R A}$ measure, but show results using $P_{s, t}^{M o r e t t i}$ as well as $P_{s, t}^{B L S}$, which is a price index based on BLS city price indexes but is only available for roughly twenty cities. See data appendix A.2 for details.

${ }^{16}$ I also provide supplemental evidence on payrolls, which are from the County Business Patterns, as well as employment rates. The employment rate is the share of people in the labor force who are employed.

${ }^{17}$ I follow the approach of Busso et al. (2013) and Suárez Serrato and Zidar (2016) to construct composition- 
variable sources and definitions. Real wages and real composition-constant wages are these nominal series divided by a price index, which is $P_{s, t}^{A C C R A}$ unless otherwise specified.

There are two main sets of controls. First, I include controls on oil prices and real interest rates from Nakamura and Steinsson (2014). Second, I use controls for contemporaneous policy and spending changes. I construct microsimulation models to measure social insurance policy changes in an analogous way to my tax shocks. ${ }^{18}$ Specifically, I develop a state-specific, formula-driven mechanical change in spending for Aid to Families with Dependent Children (AFDC), Temporary Assistance for Needy Families (TANF), the Supplemental Nutrition Assistance Program (SNAP), Supplemental Security Income (SSI), and Medicaid. I then divide each mechanical spending change by state GDP. To supplement these controls, I also control directly for several other policy parameters that are enumerated in data appendix A.3.

\subsubsection{Non-Tax Data at the National Level}

Aggregate macroeconomic outcome variables come from the BEA. In particular, real GDP, consumption, investment, and government data are the chain-type quantity indexes from the Bureau of Economic Analysis' National Income and Product Accounts Table 1.1.3; the nominal GDP data come from the National Income and Product Accounts Table 1.1.5.

\section{Econometric Methods}

This section describes how I estimate the relationship between changes in taxes for different groups and subsequent economic activity. First, I fit distributed lag models and direct projections to look at the dynamic relationship between (i) tax changes by income group and (ii) subsequent changes in economic activity at the state level. I then consider a more parsimonious specification that estimates the relationship between (i) two-year changes in taxes by income group and (ii) two-year changes in economic activity. Second, I study these relationships at the national level using a specification that is similar to that of Romer and Romer (2010), but has tax changes that are decomposed by income group. The national approach, while inherently noisy and suggestive due to limited data, supplements the state results by quantifying aggregate effects.

constant wages.

${ }^{18}$ Appendix $\mathrm{C}$ provides more detail on these microsimulation models. 


\subsection{State-level Effects of Tax Changes for Different Income Groups}

\subsubsection{Distributed Lag Model of Tax Changes for Different Income Groups}

In a given state $s$ and year $t$, changes in the outcome $y_{s, t}$ between year $t-1$ and $t$ are decomposed into a state component $\mu_{s}$, a time component $\delta_{t}$, the effects of current and lagged tax shocks $T_{s, t}^{g}$ for income group $g$, an index of time-varying state-characteristics $\mathbf{X}_{s, t}^{\prime} \boldsymbol{\Lambda}$, and a residual component $\varepsilon_{s, t}$ :

$$
y_{s, t}-y_{s, t-1}=\sum_{g}\left(\sum_{m=\underline{m}}^{\bar{m}} \beta^{g, m} T_{s, t-m}^{g}\right)+\mathbf{X}_{s, t}^{\prime} \mathbf{\Lambda}+\mu_{s}+\delta_{t}+\varepsilon_{s, t},
$$

where $g \in\{$ Bottom 90, Top 10$\}$ indexes the income groups and the time index $m$ for the lags of tax changes range from $\underline{m}=0$ and $\bar{m}=2$ in the baseline specification. ${ }^{19} T_{s, t}^{B 90}$ is an exogenous tax shock as a share of state GDP for taxpayers who are in the bottom $90 \%$ of AGI nationally and $T_{s, t}^{T 10}$ is defined analogously. Tax shocks are expressed as a share of state GDP to facilitate comparisons over time.

For OLS to identify the parameters of interest, tax shocks need to be exogenous conditional on fixed effects and controls, i.e., $\mathbb{E}\left(\varepsilon_{s, t} \mid T_{s, t}^{B 90}, T_{s, t}^{T 10}, \mathbf{X}_{s, t}, \mu_{s}, \delta_{t}\right)=0$. Intuitively, this identifying assumption is that national tax shocks, which Romer and Romer (2010) define as exogenous, are not disproportionately favoring states that are doing poorly relative to how fast they normally grow. The validity of comparing outcomes of states with different income distributions relies on three key assumptions: (1) state tax shocks are exogenous, (2) targeted tax shocks are unrelated to targeted spending shocks, and (3) outcomes from less exposed states provide a reasonable counterfactual in the absence of the tax shock.

Since I control for state and year fixed effects in equation 1, the first assumption maintains that federal policymakers are not systematically setting tax policy to respond to idiosyncratic state shocks. Relying on variation from federal tax changes that Romer and Romer (2010) classify as exogenous makes it less likely policymakers are responding to idiosyncratic state shocks since the Romer and Romer (2010) changes are due to concerns about long-run aggregate growth and inherited budget deficits. ${ }^{20}$

\footnotetext{
${ }^{19}$ Similar results with different lead and lag structures are also presented in the appendix.

${ }^{20}$ To support the exogeneity assumption by income group, I show that these federal tax shocks for each income group pass the Favero and Giavazzi (2012) orthogonality test, which amounts to showing that the raw series of tax shocks by group are similar to these series after partialling out macro aggregates.
} 
Even if state tax shocks are exogenous, they may occur at the same time as other progressive policy changes. If progressive tax and spending policy systematically occur at the same time and both increase growth, then $\beta^{B 90}$ would reflect both the true effect of tax changes for the bottom $90 \%$ and the effects of spending policies, resulting in upwardly-biased estimates. To address this concern, I directly control for government transfer payments as well as specific policy parameters. I first control for a comprehensive measure of total government spending on transfer programs, but this amount of spending responds to economic conditions. To isolate changes in policy parameters from changes in economic conditions, my preferred approach is to control for mechanical policy-induced changes in social insurance program spending. I include the mechanical policy-induced spending changes of several key transfer programs in the vector of controls $\mathbf{X}_{s, t}$ in the baseline specification, and then present estimates that control for additional policy parameters in robustness specifications.

I provide several pieces of evidence to support the third assumption that outcomes from less exposed states provide a reasonable counterfactual in the absence of the tax shock. I consider the possibility that states that disproportionately benefit from a given tax change may be generally more cyclical. I do so by replacing year fixed effects $\delta_{t}$ in equation 1 with $\delta_{q(s), t}$ where $\delta_{q(s), t}$ is each state's cyclicality-quintile-specific year fixed effect. The function $q(s):\{A L, A K, \ldots, W Y\} \rightarrow\{1, \ldots, 5\}$ gives the quintile of the state's sensitivity to national changes in economic conditions. I present a few ways to measure how cyclically-sensitive each state is, but the baseline approach follows the $\beta$-differencing approach of Blanchard and Katz (1992), which regresses changes in state economic activity on national changes in economic activity to estimate the state's average responsiveness to national shocks. ${ }^{21}$ The resulting groupby-year fixed effect $\delta_{q(s), t}$ measures common year shocks in the 10 states with similar levels of cyclicality. Additionally, I consider regional trends as well as other controls used in the regional multiplier literature (e.g., state-specific trends and state-specific interest rate and oil price sensitivity). I provide further support for the third assumption by examining the path of economic activity preceding tax shocks for bottom- and top-income groups.

\footnotetext{
${ }^{21}$ See appendix B.1 for details. I also show results using deciles instead of quintiles and using quintiles of each state's standard deviation in real GDP per capita $\sigma_{s, 1963-1979}$ in the years preceding the sample period 1980-2007.
} 


\subsubsection{Direct Projections of Tax Changes for Different Income Groups}

To examine how the path of economic activity evolves before and after tax shocks for bottomand top-income groups, I run a series of direct projection regressions for different horizons $h \in\{-4,-3, \ldots, 5\}:$

$$
y_{s, t+h}-y_{s, t-1}=\alpha_{h}^{B 90}\left(T_{s, t}^{B 90}\right)+\alpha_{h}^{T 10}\left(T_{s, t}^{T 10}\right)+\mathbf{X}_{s, t}^{\prime} \boldsymbol{\Lambda}_{h}+\mu_{s, h}+\delta_{t, h}+\varepsilon_{s, t, h},
$$

where $s$ and $t$ index state and year, $y_{s, t+h}-y_{s, t-1}$ is a measure of growth in economic activity at horizon $h$, and $\mu_{s, h}$ and $\delta_{t, h}$ are horizon-specific state and year fixed effects. ${ }^{22}$ The path of economic activity around the tax shocks for bottom and top-income groups is described by the sequences of coefficients $\left\{\alpha_{h}^{B 90}\right\}_{h=-4}^{h=5}$ and $\left\{\alpha_{h}^{T 10}\right\}_{h=-4}^{h=5}$, which quantify the impacts of these shocks on economic activity over different horizons. As noted by Jorda (2005); Stock and Watson (2007); Auerbach and Gorodnichenko (2013), using direct projections of tax shocks on outcomes is attractive because it does not impose dynamic restrictions on the estimates at different horizons. I use these specifications to estimate average outcomes before tax shocks to determine if tax shocks for different groups occur soon after unusually good or bad economic times. The direct projection approach also shows how the effects of tax changes vary over time and can potentially reveal anticipatory effects, which may vary by income group.

\subsubsection{Two-Year Effects of Tax Changes for Different Income Groups}

While the direct projection specifications are useful for examining how economic activity evolves around a tax change, I fit more parsimonious models that use two-year changes to show the cumulative effects of tax changes on employment and income for different income groups. ${ }^{23}$ The two-year specification follows a similar specification to Nakamura and Steinsson (2014), but for tax shocks (by income group) rather than for government spending shocks:

\footnotetext{
${ }^{22}$ In the baseline specification, I use cyclicality-quintile year fixed effects described in the prior section, i.e., $\delta_{q(s), t}$ formed using the $\beta$-differencing approach of Blanchard and Katz (1992), which are indexed by the horizon, i.e., $\delta_{q(s), t, h}$. I also include the mechanical policy-induced spending changes of several key transfer programs in the vector of controls $\mathbf{X}_{s, t}$ in the baseline specification as well. Specifically, the 5 distinct policy controls are the mechanical changes in AFDC, TANF, SNAP, SSI, and Medicaid spending as a percentage of state GDP.

${ }^{23}$ Note that each of the elements of the tax shock are normalized by the initial level of state GDP (i.e., $Y_{s, t-2}$ ). There is nothing special about two-year changes per se other than that this duration is somewhat standard in this literature (e.g., Nakamura and Steinsson (2014)).
} 


$$
\frac{Y_{s, t}-Y_{s, t-2}}{Y_{s, t-2}}=b^{B 90}\left(\sum_{m=0}^{2} T_{s, t-m}^{B 90}\right)+b^{T 10}\left(\sum_{m=0}^{2} T_{s, t-m}^{T 10}\right)+\mathbf{X}_{s, t}^{\prime} \mathbf{\Lambda}+a_{s}+d_{t}+e_{s, t} .
$$

In this case, the year fixed effects $d_{t}$ absorb common aggregate macroeconomic shocks and the state-fixed effects effectively control for different state trends in the outcome. An advantage of this specification is that the average effects of tax changes are captured by one parameter for each income group (rather than a parameter for each lag of each income group). I use $d_{q(s), t}$ instead of $d_{t}$ in the baseline specification (where $d_{q(s), t}$ is each state's cyclicality-quintile-specific year fixed effect) and also control for mechanical policy-induced spending changes.

\subsection{National Effects of Tax Changes for Different Income Groups}

I also fit specifications similar to equation 1 at the national level:

$$
y_{t}-y_{t-1}=\sum_{m=\underline{m}}^{\bar{m}}\left(\gamma^{B 90, m} T_{t-m}^{B 90}+\gamma^{T 10, m} T_{t-m}^{T 10}+\mathbf{X}_{t-m}^{\prime} \boldsymbol{\Gamma}_{m}\right)+\nu_{t}
$$

where $\gamma^{B 90, m}$ and $\gamma^{T 10, m}$ are the effects of changes in taxes as a share of GDP at lag $m$ and the time index $m$ for the lags of tax changes range from $\underline{m}=0$ and $\bar{m}=2$ in the baseline specification. $T_{t}^{B 90}$ is an exogenous tax shock as a share of national GDP for taxpayers who

are in the bottom $90 \%$ of AGI nationally and $T_{t}^{T 10}$ is defined analogously. $\mathbf{X}_{\mathbf{t}}=\left[T_{\text {NONINC, }}\right]$ includes non-income and non-payroll tax changes that Romer and Romer (2010) classify as exogenous (e.g., corporate tax changes). One way to interpret equation 4 is that it decomposes the Romer and Romer (2010) exogenous tax change measure into three mutually exclusive and collectively exhaustive components: $T_{t}^{B 90}, T_{t}^{T 10}$, and the non-income and non-payroll portion, i.e., $T_{N O N I N C, t}$.

\section{Effect of Tax Changes for Different Income Groups}

This section provides results on the effects of tax changes for different income groups on economic activity. Section 3.1 provides evidence on the effects of tax changes for different groups on employment and income growth. Section 3.2 provides results for mechanisms and highlights supplemental national results. Section 3.3 discusses the estimates and relates them to existing 
evidence. Finally, section 3.4 briefly describes additional support for the validity of the estimates and robustness tests.

\subsection{Impacts on State Economic Activity}

Figure 3 shows the evolution of the state employment-to-population ratio and state employment relative to the year before a tax change for different income groups. Panel A shows that the employment-to-population ratio exhibits little trend prior to tax changes and then gradually falls in the years following a tax change for the bottom 90\%. Specifically, the estimates for the impact of tax changes in year $h$ for the bottom $90 \%, \hat{\alpha}_{h}^{B 90}$ from equation 2, and those for the top $10 \%, \hat{\alpha}_{h}^{T 10}$, are shown in blue and red respectively. The employment-to-population ratio is roughly 4 percentage points lower three years after a 1\% of state GDP tax change for the bottom $90 \%$ relative to the employment-to-population ratio the year before the tax change (i.e., $\hat{\alpha}_{3}^{B 90} \approx 4$ ). After four years, on average, the ratio improves slightly to be roughly 3 percentage points below the level prior to the tax change. Panel B shows similar patterns for state employment. State employment tends to be $2 \%$ lower in the year after the tax change for the bottom $90 \%$, falls to $4 \%$ two years after the change, and then recovers somewhat to be roughly $2 \%$ lower four years after the tax change. Tax changes for the top $10 \%$, in contrast, have no detectable impact on the state employment-to-population ratio and state employment in the eight-year window around tax changes.

Figure 4 shows the evolution of the state income and prices. Panel A shows that nominal state GDP sharply declines following tax changes for the bottom $90 \%$ and is roughly 8 percent lower than the year before the tax change. These declines are very large. ${ }^{24}$ However, panel B shows prices also fall by roughly 6 percent. This price decline estimate is noisy, but indicates that the GDP declines are smaller in real terms. Panels $\mathrm{C}$ and D show results for real GDP using the ACCRA price index $P_{s, t}^{A C C R A}$ and a home-price-based index $P_{s, t}^{H P I}$. The real series show smaller impacts, especially three and four years after the tax changes for the bottom $90 \%$. In terms of estimates from tax changes for the top 10\%, estimates for both measures of income in nominal and real terms provide no evidence that tax changes for high-income earners materially impact economic activity over a business cycle frequency. ${ }^{25}$

\footnotetext{
${ }^{24} \mathrm{I}$ discuss the magnitudes and relate them to existing literature in section 3.3.

${ }^{25}$ While it is possible that the effects show up further into the future, detecting such effects is inherently difficult. See Romer and Romer (2014) for some historical evidence on longer-term effects.
} 
Table 1 presents the main regression estimates of state employment and income. Panel A shows estimates of the distributed lag specification using equation 1 as well as the sum of effects $\sum_{m=0}^{2} \beta^{g, m}$ of tax changes for each group $g \in\{$ Bottom 90, Top 10\}. Panel B shows estimates from the more parsimonious two-year change specification using 3. For each panel, the baseline specification is a rich set of controls: mechanical policy changes in spending as a share of state GDP on social insurance programs (AFDC, TANF, SNAP, SSI, and Medicaid) as well as state and cyclicality-quintile by year fixed effects. Employment declines roughly $3.5 \%$ in both specifications following a tax change of 1\% of state GDP for the bottom 90\%, and top tax changes have no impact in either specification. Panel B also reports the p-value for the test that $b^{B 90}=b^{B 90}$, i.e., that the impacts on two-year employment growth from tax changes for both groups are equal. This test is rejected with $94 \%$ confidence in column 1 . The employment-topopulation ratio also shows similar patterns but is less precise over a two-year window relative to three and four years after the tax change as shown in Figure 3. The next three columns show estimates for nominal and real state GDP. The impacts are very large for the bottom $90 \%$ and not for the top 10\%. Although the point estimates for state GDP are less stable and range from $5.3 \%$ to $9.2 \%$, the qualitative pattern of nearly all responsiveness from lower-income groups and small impacts from top groups is very robust. ${ }^{26}$ Each specification rejects the null hypothesis of equal impacts from tax changes for the bottom $90 \%$ and top $10 \%$ with more than $99 \%$ confidence.

\subsection{Mechanisms}

The results in section 3.1 show large employment and income declines after tax changes affecting lower-income taxpayers. These employment and income results are reduced-form estimates that reflect changes in both the supply and demand for labor following a tax change. This section discusses impacts on labor market outcomes and on consumption, the relative importance of supply and demand changes at the state level, and effects on aggregate investment.

Figure 5 shows the impacts of tax changes for different groups on extensive and intensive labor market responses, real wages, and consumption. On the extensive margin, Panel A shows that labor force participation rates decline roughly 3 percentage points three and four years

\footnotetext{
${ }^{26}$ Appendix Tables A8 and A9 show robustness tests for nominal state GDP. Appendix Tables A10 and A11 show robustness tests for real state GDP.
} 
after a tax change for the bottom 90\%. On the intensive margin, hours of workers who work at least 48 weeks decline by roughly 2 percent soon after the tax change but return to the levels before the tax change. ${ }^{27}$ Panel $\mathrm{C}$ shows that real wages increase following tax changes for the bottom $90 \%{ }^{28}$ These real wage results, though imprecise, reveal the relative importance of supply and demand changes in the labor market. The increase in real wages suggests that supply-side responses are important and may exceed demand-side responses to tax changes for the bottom $90 \%$.

In terms of aggregate mechanisms, Table 4 shows national results for real GDP and its components. Real GDP decreases 3.8\% following tax changes for the bottom $90 \%$ and decreases $1.1 \%$ following tax changes for the top $10 \%$. These point estimates are noisy - the standard error for the top $10 \%$ estimate is $4.6 \%$ at the national level - but could be consistent with impacts of tax changes from the top $10 \%$ that spillover to other states. That said, the impacts on the top $10 \%$ are statistically indistinguishable from zero and 2.7 percentage points lower than the aggregate estimate for the bottom $90 \%$. The components of GDP are also noisy. ${ }^{29}$ Other than the impacts on investment, which are much more responsive to tax changes for the bottom $90 \%$ and are weakly significant statistically, there is not enough variation in the time series to pin down heterogeneous effects on macro aggregates. ${ }^{30}$ The investment responses and the overall real GDP point estimates, however, suggest that the effects of additional economic growth from tax changes for the bottom $90 \%$ tend to exceed the effects from income changes among those who are more likely to save.

\footnotetext{
${ }^{27}$ Results are similar for hours of workers who work on average at least 35 hours per week and at least 48 weeks per year.

${ }^{28}$ Nominal wages tend to be roughly flat but then increase following tax changes for the bottom $90 \%$. Panel $\mathrm{C}$ uses the ACCRA price index $P_{s, t}^{A C C R A}$ as a deflator and adjusts wages holding constant the composition of workers, which indicates that the real wage increases are reflecting actual increases rather than compositional shifts in labor supply. Results using other deflators and raw average wages are similar and presented in appendix Figure A14.

${ }^{29}$ Given the limited number of tax changes events in the postwar period, the possibility of coincidental trends in income inequality, for example, suggests caution when interpreting the national results and provides another reason why evidence from the state-level analysis, especially when the analysis accounts for regional trends, may be more informative.

${ }^{30}$ The consumption results are somewhat mixed. Although durable good consumption is much more responsive to bottom $90 \%$ tax changes, the non-durable consumption estimates work in the opposite direction, leading to similar overall consumption impacts. The similarity in consumption impacts is inconsistent with the literature on MPCs and the state-level results in Figure 4 which show much larger responses from the bottom $90 \%$ on consumption.
} 


\subsection{Discussion of Results}

Quantitatively, the main reduced-form results in this paper are large, but within a range that is consistent with existing cross-sectional evidence. In particular, the $3.4 \%$ estimate for the increase in state employment from a 1\% of GDP tax cut for the bottom $90 \%$ translates to roughly $\$ 31,500$ per job. ${ }^{31}$ These cost-per-job estimates are consistent with those reported in Ramey (2011): $\$ 25,000$ in Wilson (2012), roughly $\$ 28,600$ in Chodorow-Reich et al. (2012), \$30,000 in Suárez Serrato and Wingender (2011), and \$35,000 in Shoag (2010). ${ }^{32}$ My estimates for the impact of tax cuts for the top $10 \%$ on employment are statistically and economically indistinguishable from zero, so the corresponding cost-per-job estimate is much higher. Therefore, given my estimates by income group, the overall impact of a tax cut of $1 \%$ of GDP that goes half to the bottom $90 \%$ and half to the top $10 \%$ will have roughly a $\$ 63,000$ cost-per-job.

The estimates for impacts on real income, however, are larger than most papers in this literature. ${ }^{33}$ First, the variation that I am exploiting could potentially yield stronger effects than prior studies. Second, the confidence intervals are large, so one cannot rule out smaller effects. Third, in terms of point estimates, the average output multiplier in a recent survey by ChodorowReich (2017) is 2.1, though some studies estimate sizable cumulative output multipliers (e.g., Leduc and Wilson (2015) estimate a cumulative multiplier of 6.6). The estimated impact on real income from the bottom $90 \%$ depends on the specification, but is roughly $7 .{ }^{34}$ The impact from the top $10 \%$ is roughly zero, so the overall multiplier on real income, computed as the average of the group-specific multipliers, is roughly 3.5. It is important to emphasize that these estimates are regional multipliers, which can differ from national multipliers to the extent that time fixed effects absorb general equilibrium forces (e.g., countercyclical monetary policy). ${ }^{35}$ Since state

\footnotetext{
${ }^{31}$ Using 2011 numbers, the cost of a 1\% of GDP tax cut is roughly $\$ 150$ billion and a $3.4 \%$ increase in employment on a base of 140 million is 4.76 million. Therefore, the cost-per-job is $\frac{\$ 150,000 M}{4.76 M}=\$ 31,513$.

${ }^{32}$ Note that Wilson (2012) and Chodorow-Reich et al. (2012) focus on effects during a recession, which likely results in lower cost-per-job estimates. There are also estimates of smaller multipliers (e.g., Clemens and Miran (2012)). See Chodorow-Reich (2017) for a recent survey.

${ }^{33}$ Nakamura and Steinsson (2014), for example, find output multipliers from government spending of 1.32 to 4.79 in their Table 3 and roughly similar estimates for output multipliers in real terms.

${ }^{34}$ See, for example, Figure 4 panels $\mathrm{C}$ and $\mathrm{D}$ or the real income estimates in Table 1 or appendix Tables A6 and A7. Other measures of income, e.g., total personal income from CPS, increase by roughly $5 \%$ as shown in appendix Figure A21, but these estimates are noisy.

${ }^{35}$ Although regional multipliers are generally believed to be larger than national multipliers, the relative size of regional and national multipliers is an active area of research (Chodorow-Reich, 2017). It is also worth noting that common national shocks like countercyclical monetary policy are not likely to be fully absorbed by time fixed effects given regional heterogeneity and the possibility of heterogeneous impacts of monetary policy changes.
} 
GDP, particularly in real terms, is measured with error, ${ }^{36}$ my preferred interpretation of these results is that the point estimates for real income are more variable and thus less reliable than the employment estimates, but impacts on both outcomes provide robust evidence that economic activity is substantially more responsive to tax changes for the bottom $90 \%$ than to those for the top 10\%. Okun's law suggests that employment and GDP are closely related, so putting emphasis on the better measured of the two seems advantageous.

In terms of mechanisms and the relative importance of consumption and labor supply responses, rationalizing the large responses in economic activity through consumption responses alone is not persuasive. First, the traditional multiplier of $\frac{M P C}{1-M P C}$ would require marginal propensities to consume that are larger than most MPCs estimated in the literature, e.g., Johnson et al. (2006) and Parker et al. (2013). Second, in terms of heterogeneous MPCs by income group, the initial impact on consumption could be sizable, ${ }^{37}$ but the subsequent rounds do not feed back exclusively to lower-income groups, so the MPCs in subsequent rounds are not the MPCs of lower-income consumers, but economy-wide average MPCs. Third, to the extent some of the initial spending is on durable goods, which are often traded, the impacts from increased consumption may not be especially concentrated in the states where tax change recipients live (other than through spillovers to the consumption of complementary non-tradables). Substantial labor supply responses, therefore, are likely an important mechanism, which is consistent with the evidence presented on labor force participation, hours, and real wages.

One may find these results surprising from the perspective of the theoretical literature. Although the employment estimates are comparable to those in the empirical literature on regional multipliers, it may be somewhat surprising from the perspective of the theoretical literature that tax cuts for lower-income earners are more effective than government spending. ${ }^{38}$ Farhi and Werning (2016), however, show that externally-financed regional multipliers with

\footnotetext{
${ }^{36} \mathrm{BEA}$ relies on measures from a range of sources when computing state GDP, many of which are from the economic census. The economic census is compiled every five years and in non-benchmark years, state GDP estimates involve "interpolation and extrapolation techniques using indicator series that mirror the movement in the GDP by state component being estimated." See https ://www . bea.gov/regional/pdf/gsp/GDPState.pdf.

37 Aaronson et al. (2012) show that household spending increases by roughly $\$ 700$ per quarter following a $\$ 250$ per quarter income increase due to minimum wage increases. This $\frac{700}{250} \approx 3 X$ impact on spending among low-income earners comes from a small number of households that make large durable purchases following the income shock. Similar spending behavior following tax shocks for lower-income earners could generate sizable impacts on economic activity.

${ }^{38} \mathrm{MPC}$ estimates are typically smaller than 1 and the traditional government spending multiplier is $\frac{1}{1-M P C}$, so the traditional tax multiplier is smaller than the traditional government spending multiplier, i.e., $M P C<1$ implies that $\frac{M P C}{1-M P C}<\frac{1}{1-M P C}$.
} 
redistribution and non-Ricardian agents can be larger than traditional multipliers. Additionally, other channels, such as extensive margin labor supply responses with heterogeneous agents, are often not incorporated and can impact conclusions about multipliers.

The results may also be surprising in terms of Ricardian equivalence. Ricardian agents will increase expenditures based on the annuity value of the tax change, which may be zero if they expect to finance the tax change in the future. ${ }^{39}$ However, there are a few reasons why Ricardian equivalence may fail, especially when considering tax changes for lower-income groups in a spatial setting. First, agents may consider tax changes a transfer if the tax change is (i) financed contemporaneously by other agents (from other locations or from other income groups) or (ii) if they expect others to pay for it in the future. Second, agents may be liquidity constrained. Third, agents may be myopic. These considerations may also help explain why there are different impacts for different income groups.

\subsection{Threats to Validity and Robustness}

There are three key threats to the validity of the estimates: endogenous tax changes, prior economic conditions and differential trends, and concomitant progressive government spending changes. First, I assess the concern that the composition of tax shocks may be endogenous by appealing to an orthogonality test used by Favero and Giavazzi (2012). This test compares the federal tax change series before and after partialling out macro aggregates. Appendix Figure A8 shows that the raw tax shock series and the orthogonalized tax shock series are very similar for each income group, supporting the compositional exogeneity assumption. ${ }^{40}$

Tables 2 and 3 present distributed lag estimates for a wide range of robustness tests to address the second and third concerns, respectively. Table 2 shows impacts of tax changes on state employment growth. ${ }^{41}$ The first five columns present different ways to account for statespecific cyclicality; (1) presents the baseline specification with cyclicality-quintile by year fixed effects, (2) presents year effects, (3) presents cyclicality-quintile by year fixed effects where the

\footnotetext{
${ }^{39}$ This discussion of Ricardian equivalence draws from the discussion of Ricardian equivalence and regional multipliers in Chodorow-Reich (2017).

${ }^{40}$ More generally, tax changes could be endogenous by income group, year, and state. I address concerns with respect to the timing and location of tax changes by using only tax changes Romer and Romer (2010) classify as exogenous and by exploiting regional variation in the income distribution.

${ }^{41}$ Appendix Tables A8 and A9 show results for nominal state GDP. Appendix Tables A10 and A11 show results for real state GDP.
} 
quintiles are defined based on the standard deviation in state GDP per capita, (4) cyclicalitydecile by year fixed effects, and (5) cyclicality-quintile by year fixed effects that group states only using the years before the sample (i.e., before 1980). The next five columns show controls for state-specific sensitivity to other shocks and trends; (6) controls for oil price interacted with state dummies, (7) controls for real interest rate interacted with state dummies, (8) and (9) add region fixed effects to (6) and (7), and (10) includes state-specific trends. The specific point estimates for the impact on employment growth from tax changes for the bottom $90 \%$ depend on the specification, are almost always significant statistically, and tend to be within a one percentage point range of the baseline estimates. Similar patterns emerge in Table 3, which shows results for a wide range of policy parameters and controls for government spending. Panel $\mathrm{B}$ of both tables show the same controls using the two-year change specification for additional measures of economic activity and show similar patterns. For example, Table 3 shows that two-year employment growth following a tax change for the bottom $90 \%$ ranges between 3.2 percent to 3.6 percent across 11 different policy controls. Overall, the general patterns are quite robust. Almost all the impact on economic activity from tax changes comes from tax changes from the bottom $90 \%$.

\section{Conclusion}

This paper quantifies the importance of the distribution of tax changes for their overall impact on economic activity. I construct a new data series of tax changes by income group from tax return data. I use this series and variation from the income distribution across states and federal tax shocks to estimate the effects of tax changes for different groups. I find that the stimulative effects of income tax cuts are largely driven by tax cuts for the bottom $90 \%$ and that the empirical link between employment growth and tax changes for the top $10 \%$ is weak to negligible over a business cycle frequency. These effects are not confounded by changes in progressive spending, state trends, or prior economic conditions. The effects seem to come from labor supply responses as well as increased consumption and investment.

These results are important for characterizing central equity-efficiency tradeoffs in tax policy. If policy makers aim to increase economic activity in the short to medium run, this paper strongly suggests that tax cuts for top-income earners will be less effective than tax cuts for 
lower-income earners. While it is possible that tax cuts for top-income earners have sizable long-run impacts through different channels such as human capital investment, firm creation, or innovation, ${ }^{42}$ much more compelling evidence on these channels is needed to support topincome tax cuts on efficiency grounds, especially given the magnitude of resources devoted to these tax policy changes. Overall, the results not only suggest some skepticism for "trickle down" economics, but they also provide evidence that supply-side tax policies should do more to consider the relative efficacy of tax cuts targeted lower in the income distribution. Finally, as a note of caution, the estimates in this paper come from modest changes in tax rates that have been executed in the post-war period; using these estimates to evaluate the likely impacts of large tax changes on high-income earners requires extrapolation beyond the observed variation in the data.

\footnotetext{
${ }^{42}$ Extending the analysis to study medium- and longer-term effects of tax changes, such as new firm creation or patent activity, is a good topic for future research.
} 


\section{References}

Aaronson, Daniel, Sumit Agarwal, and Eric French, "The Spending and Debt Response to Minimum Wage Hikes," American Economic Review, 2012, 102 (7), 3111-3139.

Auerbach, Alan and Jonathan Siegel, "Capital-Gains Realizations of the Rich and Sophisticated," American Economic Review, 2000, 90 (2), 276-282.

Auerbach, Alan J. and Yuriy Gorodnichenko, "Output Spillovers from Fiscal Policy," American Economic Review, May 2013, 103 (3), 141-46.

Autor, David H., Alan Manning, and Christopher L. Smith, "The Contribution of the Minimum Wage to US Wage Inequality over Three Decades: A Reassessment," American Economic Journal: Applied Economics, January 2016, 8 (1), 58-99.

Barro, Robert J. and Charles J. Redlick, "Macroeconomic Effects from Government Purchases and Taxes," The Quarterly Journal of Economics, 2011, 126 (1), 51-102.

Blanchard, Olivier Jean and Lawrence F. Katz, "Regional Evolutions," Brookings Papers on Economic Activity, 1992, 1992 (1), 1-75.

Busso, Matias, Jesse Gregory, and Patrick Kline, "Assessing the Incidence and Efficiency of a Prominent Place Based Policy," American Economic Review, September 2013, 103 (2), 897-947.

Chetty, Raj, John N. Friedman, Sren Leth-Petersen, Torben Heien Nielsen, and Tore Olsen, "Active vs. Passive Decisions and Crowd-Out in Retirement Savings Accounts: Evidence from Denmark," The Quarterly Journal of Economics, 2014, 129 (3), 1141-1219.

Chodorow-Reich, Gabriel, "Geographic Cross-Sectional Fiscal Multipliers: What Have We Learned?," Harvard University Working Paper, 2017.

_, Laura Feiveson, Zachary Liscow, and William Gui Woolston, "Does State Fiscal Relief During Recessions Increase Employment? Evidence from the American Recovery and Reinvestment Act," American Economic Journal: Economic Policy, 2012, 4 (3), 118-145.

Clemens, Jeffrey and Stephen Miran, "Fiscal Policy Multipliers on Subnational Government Spending," American Economic Journal: Economic Policy, 2012, 4 (2), 46-68.

Dynan, Karen, Jonathan Skinner, and Stephen Zeldes, "Do the Rich Save More?," Journal of Political Economy, 2004, 112 (2), 397-444.

Eissa, Nada and Jeffrey B. Liebman, "Labor Supply Response to the Earned Income Tax Credit," The Quarterly Journal of Economics, 1996, 111 (2), 605-637.

Farhi, Emmanuel and Ivàn Werning, "Fiscal Multipliers: Liquidity Traps and Currency Unions," Handbook of Macroeconomics, forthcoming, 2016, 2, 2417-2492.

Favero, Carlo and Francesco Giavazzi, "Measuring Tax Multipliers: The Narrative Method in Fiscal VARs," American Economic Journal: Economic Policy, 2012, 4 (2), 69-94. 
Frisch, Ragnar and Frederick V. Waugh, "Partial Time Regressions as Compared with Individual Trends," Econometrica, 1933, 1 (4), 387-401.

Galí, Jordi, J. David López-Salido, and Javier Vallés, "Understanding the Effects of Government Spending on Consumption," Journal of the European Economic Association, 2007, 5 (1), 227-270.

Goolsbee, Austan, "What Happens When You Tax the Rich? Evidence from Executive Compensation," Journal of Political Economy, 2000, 108 (2), 352-378.

Hausman, Joshua K., "Fiscal Policy and Economic Recovery: The Case of the 1936 Veterans' Bonus," American Economic Review, 2016, 106 (4), 1100-1143.

Heathcote, Jonathan, "Fiscal Policy with Heterogenous Agents and Incomplete Markets," Review of Economic Studies, 2005, 72 (1), 161-188.

Heckman, James J., "Comment," in "Behavioral Simulation Methods in Tax Policy Analysis," University of Chicago Press, 1983, pp. 70-82.

Jappelli, Tullio and Luigi Pistaferri, "The Consumption Response to Income Changes," Annual Review of Economics, 2010, 2, 479-506.

Johnson, David S., Jonathan A. Parker, and Nicholas S. Souleles, "Household Expenditure and the Income Tax Rebates of 2001," American Economic Review, 2006, 96 (5), 1589-1610.

Jorda, Oscar, "Estimation and Inference of Impulse Responses by Local Projections," American Economic Review, 2005, 95 (1), 161-182.

Kline, Patrick and Melissa Tartari, "Bounding the Labor Supply Responses to a Randomized Welfare Experiment: A Revealed Preference Approach," American Economic Review, 2016, 106 (4), 972-1014.

Kosar, Gizem and Robert A. Moffitt, "Trends in Cumulative Marginal Tax Rates Facing Low-Income Families, 1997-2007," Working Paper 22782, National Bureau of Economic Research 2016.

Leduc, Sylvain and Daniel Wilson, "Are State Governments Roadblocks to Federal Stimulus? Evidence from Highway Grants in the 2009 Recovery Act," Federal Reserve Bank of San Francisco Working Paper, 2015.

McCarthy, Jonathan, "Imperfect Insurance and Differing Propensities to Consume Across Households," Journal of Monetary Economics, 1995, 36 (2), 301-327.

Mertens, Karel, "Marginal Tax Rates and Income: New Time Series Evidence," NBER Working Paper 19171, 2013.

- and Morten O. Ravn, "The Dynamic Effects of Personal and Corporate Income Tax Changes in the United States," American Economic Review, 2013, 103 (4), 1212-1247.

_ and _, "A Reconciliation of SVAR and Narrative Estimates of Tax Multipliers," Journal of Monetary Economics, 2014, 68, S1-S19. 
Meyer, Bruce and Dan T. Rosenbaum, "Welfare, the Earned Income Tax Credit, and the Labor Supply of Single Mothers," The Quarterly Journal of Economics, 2001, 116 (3), $1063-1114$.

Monacelli, Tommaso and Roberto Perotti, "Tax Cuts, Redistribution, and Borrowing Constraints," Technical Report, Bocconi University May 2011.

Moretti, Enrico, "Real Wage Inequality," American Economic Journal: Applied Economics, 2013, 5 (1), 65-103.

Nakamura, Emi and Jón Steinsson, "Fiscal Stimulus in a Monetary Union: Evidence from US Regions," American Economic Review, 2014, 104 (3), 753-792.

Parker, Jonathan, "The Reaction of Household Consumption to Predictable Changes in Social Security Taxes," American Economic Review, 1999, 89 (4), 959-973.

Parker, Jonathan A., Nicholas S. Souleles, David S. Johnson, and Robert McClelland, "Consumer Spending and the Economic Stimulus Payments of 2008," American Economic Review, 2013, 103 (6), 2530-2553.

Ramey, Valerie A., "Can Government Purchases Stimulate the Economy?," Journal of Economic Literature, 2011, 49 (3), 673-685.

Romer, Christina D. and David H. Romer, "The Macroeconomic Effects of Tax Changes: Estimates Based on a New Measure of Fiscal Shocks," American Economic Review, 2010, 100 (3), 763-801.

_ and _ , "The Incentive Effects of Marginal Tax Rates: Evidence from the Interwar Era," American Economic Journal: Economic Policy, 2014, 6 (3), 242-281.

Ruggles, Steven, Katie Genadek, Ronald Goeken, Josiah Grover, and Matthew Sobek, "Integrated Public Use Microdata Series: Version 5.0 [dataset]," Minneapolis: University of Minnesota 2010.

Saez, Emmanuel, "Do Taxpayers Bunch at Kink Points?," American Economic Journal: Economic Policy, 2010, 2 (3), 180-212.

_ and Gabriel Zucman, "Wealth Inequality in the United States since 1913: Evidence from Capitalized Income Tax Data," The Quarterly Journal of Economics, 2016, 131 (2), 519-578.

_, Joel Slemrod, and Seth H. Giertz, "The Elasticity of Taxable Income with Respect to Marginal Tax Rates: A Critical Review," Journal of Economic Literature, 2012, 50 (1), 3-50.

Serrato, Juan Carlos Suárez and Owen Zidar, "Who Benefits from State Corporate Tax Cuts? A Local Labor Markets Approach with Heterogeneous Firms," American Economic Review, 2016, 106 (9), 2582-2624.

Shapiro, Matthew D. and Joel Slemrod, "Consumer Response to the Timing of Income: Evidence from a Change in Tax Withholding," American Economic Review, March 1995, 85 (1), 274-283. 
Shoag, Daniel, "The Impact of Government Spending Shocks: Evidence on the Multiplier from State Pension Plan Returns," Working Paper, Harvard University 2010.

Stock, James and Mark Watson, "Why has U.S. Inflation Become Harder to Forcast?," Journal of Money, Banking and Credit, 2007, 39, 3-33.

Suárez Serrato, Juan Carlos and Philippe Wingender, "Estimating Local Fiscal Multipliers," Working Paper, U.C. Berkeley 2011.

Wilson, Daniel J., "Fiscal Spending Jobs Multipliers: Evidence from the 2009 American Recovery and Reinvestment Act," American Economic Journal: Economic Policy, 2012, 4 (3), 251-282.

Yagan, Danny, "Is the Great Recession Really Over? Longitudinal Evidence of Enduring Employment Impacts," Unpublished Manuscript, 2016. 
Figure 1: Selected Historical Tax Changes for Each AGI Percentile

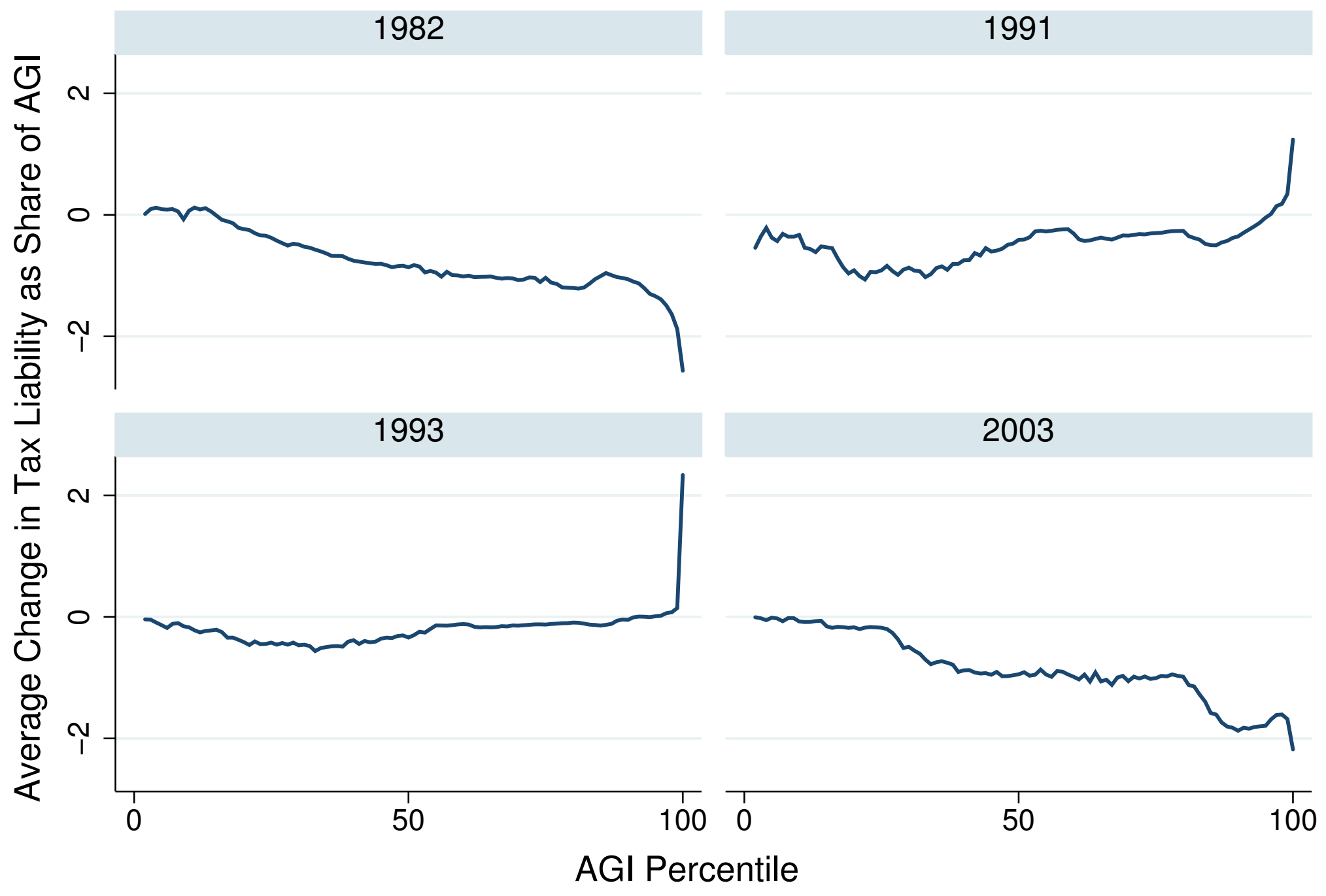

Graphs by Year

Notes: This figure displays the average mechanical change in income and payroll tax liability for each tax return in TAXSIM from tax schedule changes as a share of adjusted gross income (AGI) by AGI percentile for 1993 and for three other prominent years. For display purposes, it does not show results for the smallest AGI percentile (since the smallest income group result is amplified by a small denominator). 
Figure 2: Federal Tax Changes by Income Group and Heterogeneous High-Income Shares

\section{A. Federal Income and Payroll Tax Changes by AGI Quintile}

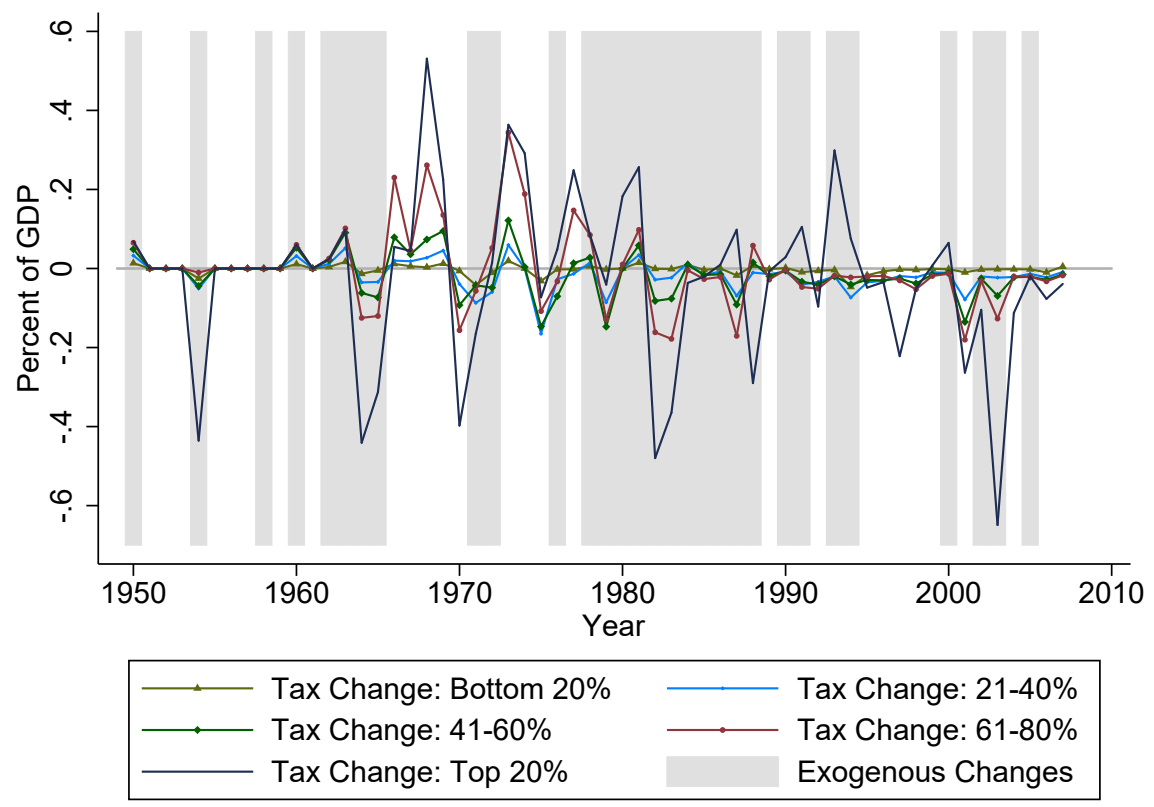

\section{B. Share of High-Income Taxpayers}

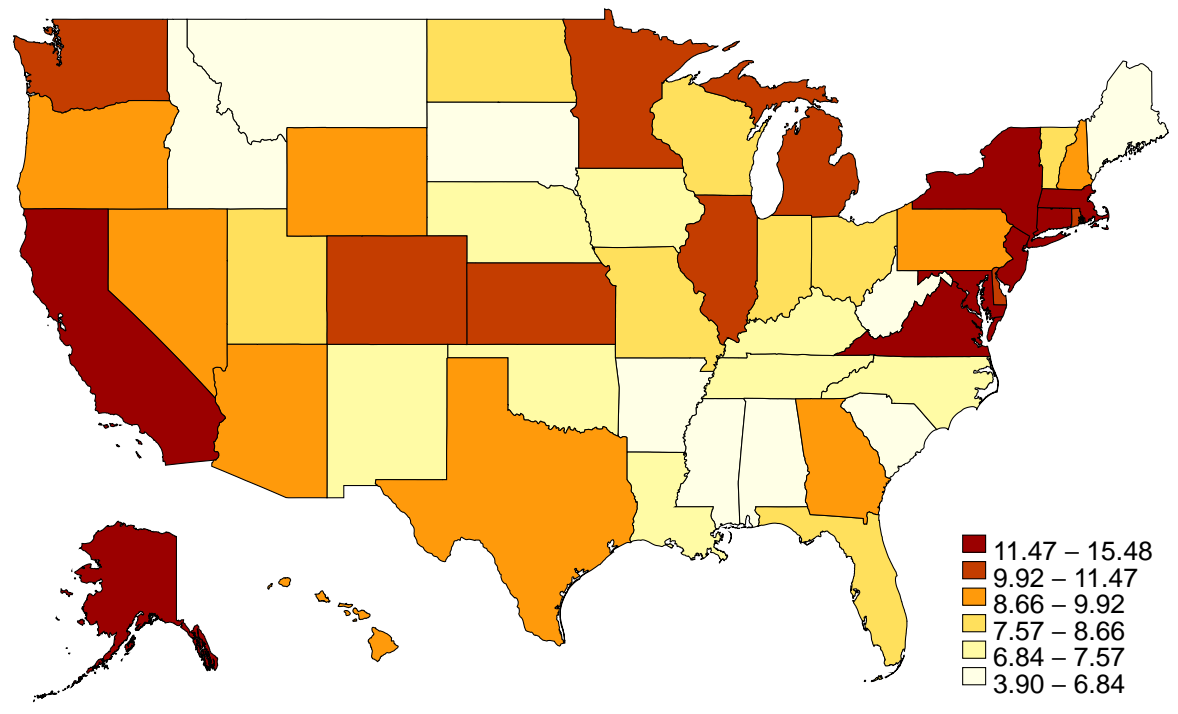

Notes: This figure shows that there is both time-series and cross-sectional variation in tax changes by income group. Panel A displays changes in individual income and payroll tax liabilities by income quintile as a share of GDP from 1950 to 2007. Tax returns from TAXSIM are used to construct a tax change measure. The period from 2008-2011 has no exogenous tax changes so those years are coded as zero exogenous change for each AGI quintile throughout the paper. Both exogenous and endogenous tax changes are shown in the figure (Appendix Table A1 shows how each tax change is classified). Panel B shows that there is substantial geographic variation in the location of households in the top-income decile. For instance, 12.4\% of households filing from Virginia are in the top $10 \%$ of AGI nationally on average from 1980-2007. The data plotted are the average shares of households filing from a given state for the years 1980-2007 who are in the top 10\% nationally in that year. 
Figure 3: Cumulative Growth in State Employment-to-Population Ratio and Employment

A. Employment-to-Population Ratio
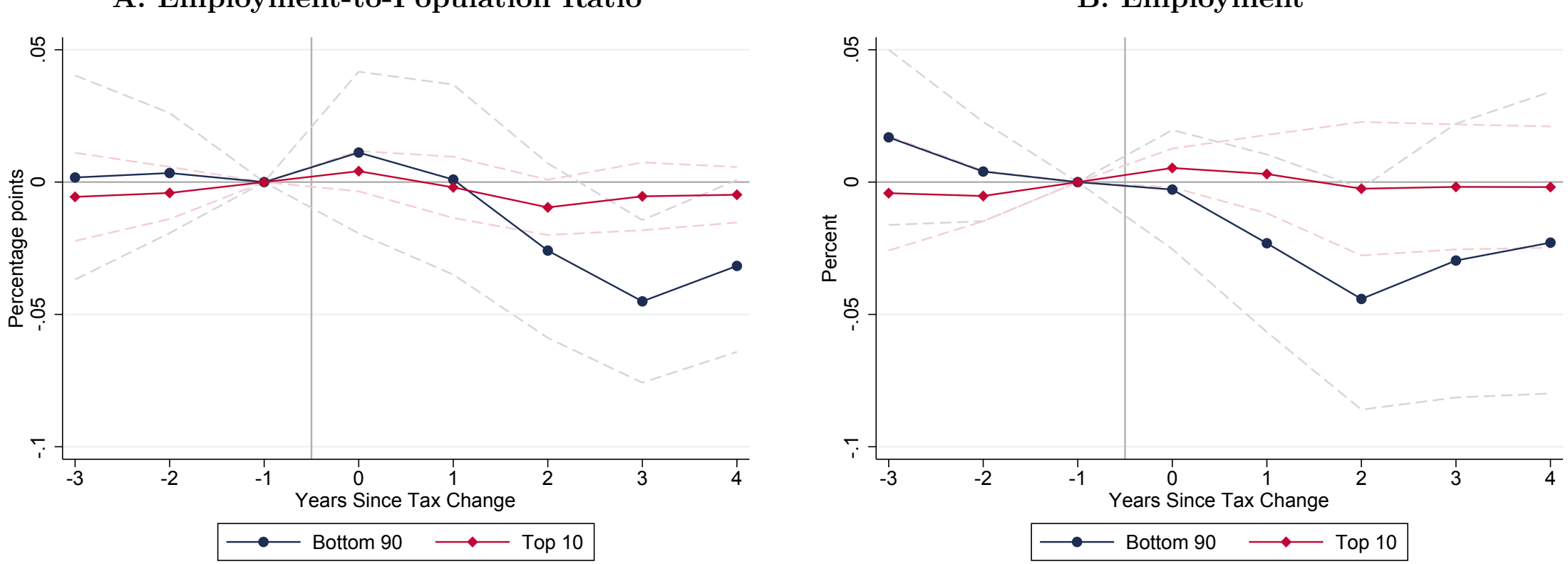

Notes: This figure shows event studies of a $1 \%$ of GDP tax increase on the state employment-to-population ratio and employment for those with AGI in the bottom $90 \%$ nationally in blue and for those with AGI in the top $10 \%$ nationally in red. Specifically, the figure plots the estimates from the baseline specification of equation 2 for the impact of tax changes in year $h$ for the bottom $90 \%, \hat{\alpha}_{h}^{B 90}$, and the top $10 \%, \hat{\alpha}_{h}^{T 10}$. The baseline specification includes controls for mechanical changes in AFDC, TANF, SNAP, SSI, and Medicaid spending as a percentage of state GDP, as well as cyclicality-quintile year fixed effects. See section 2 for details. Standard errors are robust and clustered by state; $95 \%$ confidence intervals are shown as dotted lines. The sample period is $1980-2007$. 
Figure 4: Cumulative Growth in State Economic Activity
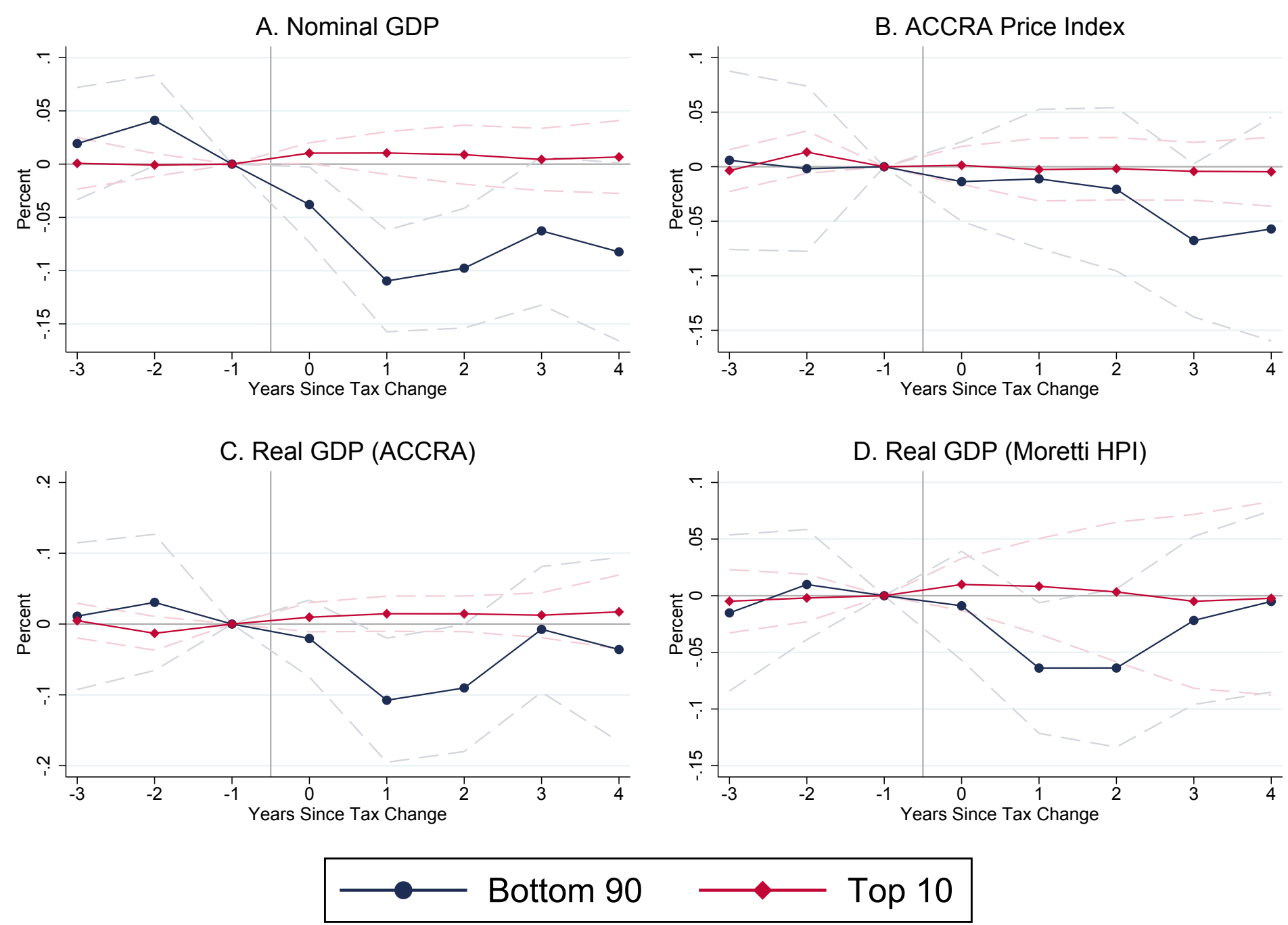

Notes: This figure shows event studies of a $1 \%$ of GDP tax increase on outcomes for those with AGI in the bottom $90 \%$ nationally in blue and for those with AGI in the top $10 \%$ nationally in red. These outcomes are (a) nominal state GDP, (b) the ACCRA state price index $P_{s, t}^{A C C R A}$, (c) real state GDP using $P_{s, t}^{A C C R A}$, and (d) real state GDP using $P_{s, t}^{M o r e t t i}$. Specifically, the figure plots the estimates from the baseline specification of equation 2 for the impact of tax changes in year $h$ for the bottom $90 \%, \hat{\alpha}_{h}^{B 90}$, and the top $10 \%, \hat{\alpha}_{h}^{T 10}$. The baseline specification includes controls for mechanical changes in AFDC, TANF, SNAP, SSI, and Medicaid spending as a percentage of state GDP, as well as cyclicality-quintile year fixed effects. See section 2 for details. Standard errors are robust and clustered by state; 95\% confidence intervals are shown as dotted lines. The sample period is 1980-2007. 
Figure 5: Cumulative Growth in State Labor Market Outcomes and Consumption
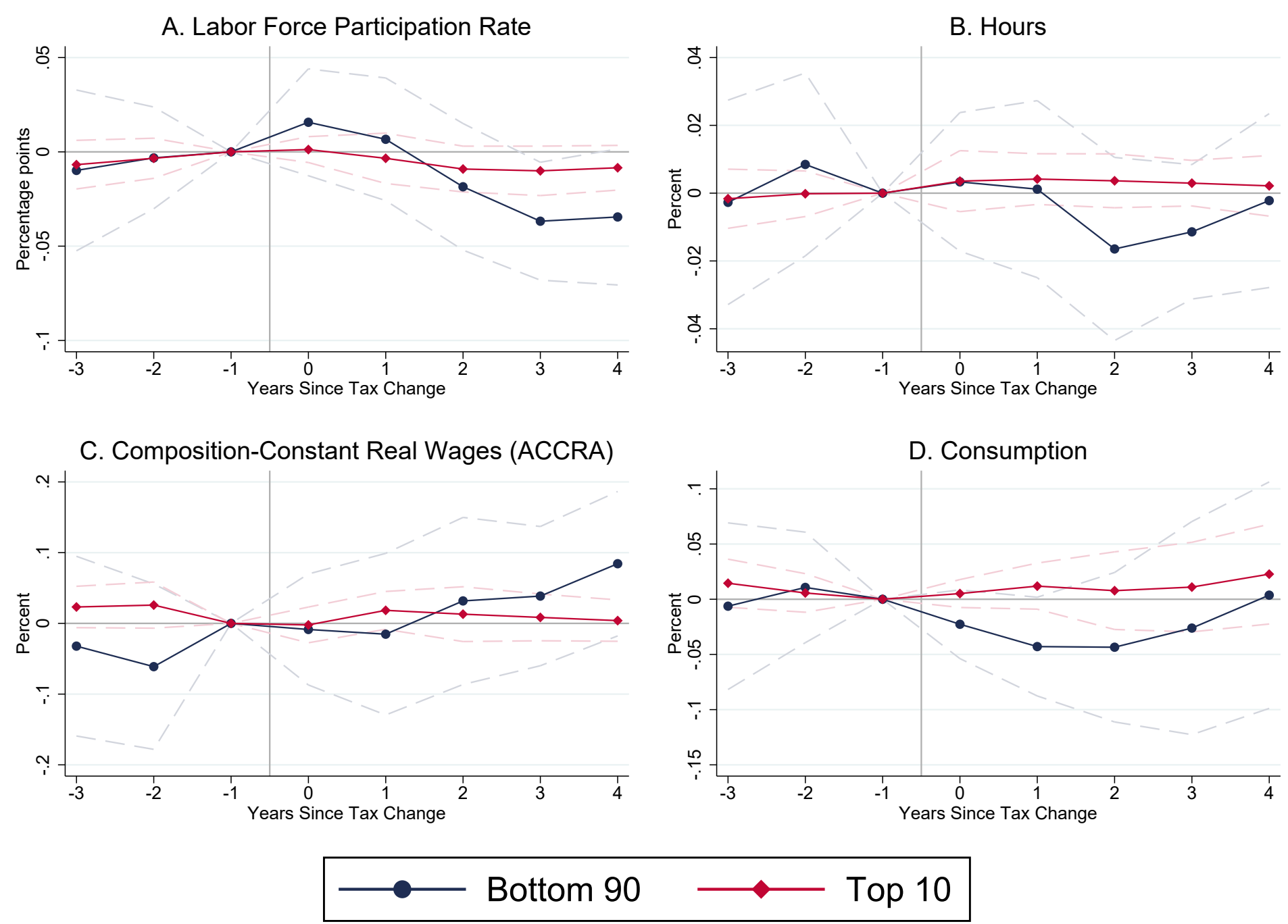

Notes: This figure shows event studies of a $1 \%$ of GDP tax increase on outcomes for those with AGI in the bottom 90\% nationally in blue and for those with AGI in the top $10 \%$ nationally in red. These outcomes are (a) labor force participation rate (in percentage points), (b) mean hours worked among those that have worked at least 48 weeks in the past year, (c) real composition-constant average wages using $P_{s, t}^{A C C R A}$, and (d) state consumption. Specifically, the figure plots the estimates from the baseline specification of equation 2 for the impact of tax changes in year $h$ for the bottom $90 \%$, $\hat{\alpha}_{h}^{B 90}$, and the top $10 \%, \hat{\alpha}_{h}^{T 10}$. The baseline specification includes controls for mechanical changes in AFDC, TANF, SNAP, SSI, and Medicaid spending as a percentage of state GDP, as well as cyclicality-quintile year fixed effects. See section 2 for details. Standard errors are robust and clustered by state; $95 \%$ confidence intervals are shown as dotted lines. The sample period is 1980-2007 for (a)-(c). However, state consumption is only available since 1997, so the sample period for (d) is 1997-2007. 
Table 1: State-level Effects of Tax Changes for Different Income Groups

\begin{tabular}{|c|c|c|c|c|c|}
\hline \multicolumn{6}{|c|}{ Panel A: Distributed Lag Model of Tax Changes for Different Income Groups } \\
\hline & Employment & Emp/Pop & Nominal GDP & Real GDP (ACCRA) & Real GDP (Moretti) \\
\hline \multirow[t]{2}{*}{ B90 } & 0.33 & 0.97 & -2.05 & -0.29 & 0.86 \\
\hline & $(1.22)$ & $(1.59)$ & $(2.18)$ & $(2.83)$ & $(2.79)$ \\
\hline \multirow[t]{2}{*}{ B90 1-Year Lag } & $-1.87^{* *}$ & -1.23 & $-7.39 * * *$ & $-8.40 * * *$ & $-5.96 * * *$ \\
\hline & $(0.89)$ & $(1.34)$ & $(1.34)$ & $(2.85)$ & $(1.87)$ \\
\hline \multirow[t]{2}{*}{ B90 2-Year Lag } & -1.98 & $-2.48^{*}$ & 0.25 & 2.11 & -0.17 \\
\hline & $(1.25)$ & $(1.35)$ & $(1.44)$ & $(2.11)$ & $(2.05)$ \\
\hline \multirow[t]{2}{*}{$\mathrm{T} 10$} & 0.52 & 0.47 & $1.05^{*}$ & 0.91 & 1.00 \\
\hline & $(0.45)$ & $(0.40)$ & $(0.58)$ & $(0.99)$ & $(1.08)$ \\
\hline \multirow[t]{2}{*}{ T10 1-Year Lag } & -0.24 & -0.66 & 0.10 & 0.88 & -0.11 \\
\hline & $(0.60)$ & $(0.41)$ & $(0.70)$ & $(0.61)$ & $(1.25)$ \\
\hline T10 2-Year Lag & -0.61 & -0.80 & -0.12 & -0.12 & -0.41 \\
\hline \multirow[t]{2}{*}{ B90 Sum: $\beta_{t}+\beta_{t-1}+\beta_{t-2}$} & -3.52 & -2.74 & $-9.19 * * *$ & -6.59 & -5.27 \\
\hline & $(2.28)$ & (1.68) & $(3.40)$ & $(4.97)$ & $(4.44)$ \\
\hline \multirow{2}{*}{ T10 Sum: $\beta_{t}+\beta_{t-1}+\beta_{t-2}$} & -0.33 & -0.99 & 1.03 & 1.67 & 0.48 \\
\hline & $(1.57)$ & $(0.65)$ & $(1.56)$ & $(1.33)$ & $(3.41)$ \\
\hline \multirow[t]{2}{*}{ Bottom - Top: } & -3.19 & -1.74 & $-10.22^{* *}$ & -8.26 & -5.75 \\
\hline & $(3.14)$ & $(1.87)$ & $(3.96)$ & $(5.10)$ & $(4.57)$ \\
\hline \multicolumn{6}{|c|}{ Panel B: Two-Year Changes } \\
\hline \multirow{3}{*}{ Bottom 90} & Employment & Emp/Pop & $\underline{\text { Nominal GDP }}$ & Real GDP (ACCRA) & Real GDP (Moretti) \\
\hline & $-3.42^{* *}$ & -1.53 & $-11.98 * * *$ & $-9.70^{* * *}$ & $-7.00^{* *}$ \\
\hline & $(1.54)$ & $(0.96)$ & $(2.21)$ & $(3.46)$ & $(2.88)$ \\
\hline \multirow[t]{2}{*}{ Top 10} & 0.22 & -0.24 & 0.75 & $1.44^{*}$ & 0.56 \\
\hline & $(0.90)$ & $(0.33)$ & $(0.96)$ & $(0.85)$ & $(2.17)$ \\
\hline P-Value (Bottom $90=$ Top 10) & 0.06 & 0.23 & 0.00 & 0.00 & 0.03 \\
\hline
\end{tabular}

Notes: Panel A presents estimates of the effects of tax changes for different income groups $g \in$ \{Bottom 90, Top 10\} at different lags $m$ from the following specification: $y_{s, t}-y_{s, t-1}=\alpha_{s}+\delta_{q(s), t}+$ $\sum_{g}\left(\sum_{m=0}^{2} \beta^{g, m} T_{s, t-m}^{g}\right)+\mathbf{X}_{s, t}^{\prime} \boldsymbol{\Lambda}+\varepsilon_{s, t}$, where $y_{s, t}$ is the log outcome (for all outcomes other than the employmentto-population ratio, which is measured in percentage terms), $\alpha_{s}$ is a state-fixed effect, $\delta_{q(s), t}$ is each state's cyclicality-quintile-specific year fixed effect where $q(s):\{A L, A K, \ldots, W Y\} \rightarrow\{1, \ldots, 5\}$ to be the quintile of the state's sensitivity to national changes in economic conditions (see section 2.1.1 or appendix B.1 for details), $T_{s, t}^{B 90}$ is an exogenous tax shock as a share of state GDP for taxpayers who are in the bottom $90 \%$ of AGI nationally, $T_{s, t}^{T 10}$ is defined analogously, and $\mathbf{X}_{s, t}$ includes controls for mechanical changes in AFDC, TANF, SNAP, SSI, and Medicaid spending as a percentage of state GDP with the same lag structure as the tax changes (i.e., current values, one year lags, and two year lags). Similarly, Panel B presents estimates of the effects of tax changes for the bottom $90 \%, b^{B 90}$, and the top $10 \%, b^{T 10}$, from the following specification: $\frac{Y_{s, t}-Y_{s, t-2}}{Y_{s, t-2}}=a_{s}+d_{q(s), t}+b^{B 90}\left(\sum_{m=0}^{2} T_{s, t-m}^{B 90}\right)+b^{T 10}\left(\sum_{m=0}^{2} T_{s, t-m}^{T 10}\right)+\mathbf{X}_{s, t}^{\prime} \mathbf{\Lambda}+e_{s, t}$, where $Y_{s, t}$ is the level of the outcome, $\frac{Y_{s, t}-Y_{s, t-2}}{Y_{s, t-2}}$ is two-year growth in the outcome, $a_{s}$ is a state-fixed effect, $d_{q(s), t}$ is each state's cyclicality-quintile-specific year fixed effect, $\left(\sum_{m=0}^{2} T_{s, t-m}^{g}\right)$ is the change in taxes over the last two years, and $\mathbf{X}_{s, t}$ includes controls for mechanical changes in AFDC, TANF, SNAP, SSI, and Medicaid spending as a share of state GDP defined analogously as the tax shocks. For the Employment-to-Population ratio, the outcome is the simple difference, i.e., $Y_{s, t}-Y_{s, t-2}$. P-values for the null hypothesis that the effects of tax changes for the bottom $90 \%$ and top $10 \%$ are the same, i.e., $b^{B 90}=b^{T 10}$, are presented in the last row of Panel B. Standard errors are clustered by state $\left(* * * \mathrm{p}<0.01,{ }^{* *} \mathrm{p}<0.05,{ }^{*} \mathrm{p}<0.1\right)$. Data are at the state-year level from 1980-2007. See appendix A.2 for data definitions and sources. 
Table 2: State-level Effects of Tax Changes by Income Group on Employment: Cyclical Robustness

\begin{tabular}{|c|c|c|c|c|c|c|c|c|c|c|c|c|}
\hline & $(1)$ & $(2)$ & $(3)$ & $(4)$ & $(5)$ & (6) & (7) & (8) & $(9)$ & $(10)$ & $(11)$ & $(12)$ \\
\hline \multicolumn{13}{|c|}{ Panel A: Distributed Lag Model of Tax Changes for Different Income Groups } \\
\hline \multirow{2}{*}{$T_{s, t}^{B 90}$} & 0.33 & 1.01 & 0.40 & 0.36 & 1.22 & 0.89 & 0.40 & 1.10 & 0.44 & -0.17 & -0.33 & -0.50 \\
\hline & $(1.22)$ & $(0.87)$ & $(0.72)$ & $(1.26)$ & $(0.93)$ & $(0.90)$ & $(0.78)$ & $(1.10)$ & (1.03) & $(1.23)$ & $(1.42)$ & $(1.29)$ \\
\hline \multirow{2}{*}{$T_{s, t-1}^{B 90}$} & $-1.87^{* *}$ & $-2.07^{* *}$ & $-1.71^{* *}$ & $-1.91^{* *}$ & $-1.41^{*}$ & $-2.14 * *$ & $-2.27 * * *$ & $-1.98^{* *}$ & $-2.37 * * *$ & $-2.22^{* *}$ & $-2.41 * * *$ & $-2.49^{* *}$ \\
\hline & $(0.89)$ & $(0.78)$ & $(0.67)$ & $(0.78)$ & $(0.76)$ & $(0.81)$ & $(0.76)$ & $(0.82)$ & $(0.65)$ & $(1.00)$ & $(0.70)$ & $(1.00)$ \\
\hline \multirow{2}{*}{$T_{s, t-2}^{B 90}$} & -1.98 & -1.17 & -0.86 & $-2.24^{*}$ & -0.85 & -1.32 & $-1.84^{*}$ & -1.19 & $-1.86^{*}$ & $-2.80^{*}$ & $-2.84^{*}$ & $-2.58^{*}$ \\
\hline & $(1.25)$ & (1.10) & $(0.87)$ & $(1.19)$ & $(1.22)$ & $(1.18)$ & $(1.03)$ & $(1.33)$ & $(0.93)$ & $(1.43)$ & $(1.42)$ & $(1.35)$ \\
\hline \multirow[t]{2}{*}{$T_{s, t}^{T 10}$} & 0.52 & 0.33 & 0.22 & 0.32 & 0.32 & 0.29 & 0.32 & 0.33 & 0.29 & 0.56 & 0.55 & 0.48 \\
\hline & $(0.45)$ & $(0.32)$ & $(0.32)$ & $(0.36)$ & $(0.28)$ & $(0.32)$ & $(0.32)$ & $(0.36)$ & $(0.36)$ & $(0.46)$ & $(0.44)$ & $(0.48)$ \\
\hline \multirow[t]{2}{*}{$T_{s, t-1}^{T 10}$} & -0.24 & -0.43 & -0.19 & -0.56 & -0.30 & -0.49 & -0.55 & -0.38 & -0.55 & -0.28 & -0.26 & -0.29 \\
\hline & $(0.60)$ & $(0.44)$ & $(0.46)$ & $(0.50)$ & $(0.36)$ & $(0.46)$ & $(0.46)$ & $(0.39)$ & $(0.43)$ & $(0.65)$ & $(0.55)$ & $(0.63)$ \\
\hline \multirow[t]{2}{*}{$T_{s, t-2}^{T 10}$} & -0.61 & -0.66 & -0.59 & -0.92 & -0.62 & -0.74 & $-0.83^{*}$ & -0.58 & $-0.82^{*}$ & -0.74 & -0.69 & -0.67 \\
\hline & $(0.67)$ & $(0.46)$ & $(0.56)$ & $(0.56)$ & $(0.42)$ & $(0.47)$ & $(0.49)$ & $(0.36)$ & $(0.42)$ & $(0.72)$ & $(0.62)$ & $(0.69)$ \\
\hline \multirow[t]{2}{*}{ B90 Sum: $\beta_{t}+\beta_{t-1}+\beta_{t-2}$} & -3.52 & -2.23 & -2.17 & $-3.80^{* *}$ & -1.04 & -2.57 & $-3.71^{* *}$ & -2.06 & $-3.79^{* *}$ & $-5.20^{* *}$ & $-5.58^{* *}$ & $-5.57 * *$ \\
\hline & $(2.28)$ & $(2.07)$ & $(1.81)$ & $(1.87)$ & $(2.11)$ & $(2.22)$ & $(1.71)$ & $(2.60)$ & $(1.66)$ & $(2.52)$ & $(2.05)$ & $(2.73)$ \\
\hline \multirow[t]{2}{*}{ T10 Sum: $\beta_{t}+\beta_{t-1}+\beta_{t-2}$} & -0.33 & -0.76 & -0.56 & -1.17 & -0.60 & -0.94 & -1.06 & -0.62 & -1.08 & -0.46 & -0.40 & -0.48 \\
\hline & $(1.57)$ & $(1.07)$ & $(1.17)$ & $(1.21)$ & $(0.85)$ & $(1.08)$ & $(1.10)$ & $(0.81)$ & $(0.96)$ & $(1.67)$ & $(1.34)$ & $(1.65)$ \\
\hline \multirow[t]{2}{*}{ Bottom - Top: } & -3.19 & -1.47 & -1.61 & -2.63 & -0.44 & -1.63 & -2.64 & -1.43 & -2.71 & -4.74 & $-5.18^{*}$ & -5.10 \\
\hline & $(3.14)$ & $(2.13)$ & $(2.43)$ & $(2.36)$ & $(2.06)$ & $(2.26)$ & $(2.17)$ & $(2.73)$ & $(2.02)$ & $(3.48)$ & $(2.78)$ & $(3.63)$ \\
\hline \multicolumn{13}{|c|}{ Panel B: Two-Year Changes } \\
\hline \multirow[t]{2}{*}{ Bottom 90} & $-3.42^{* *}$ & $-2.58^{*}$ & $-2.58^{*}$ & $-3.58^{* * *}$ & -1.55 & $-2.68^{*}$ & $-3.45^{* * *}$ & -2.45 & $-3.37^{* *}$ & $-4.25^{* *}$ & $-4.44^{* *}$ & $-4.69^{* *}$ \\
\hline & $(1.54)$ & $(1.31)$ & $(1.33)$ & $(1.28)$ & $(1.35)$ & $(1.38)$ & $(1.16)$ & $(1.77)$ & $(1.35)$ & $(1.71)$ & $(1.57)$ & $(1.80)$ \\
\hline \multirow{2}{*}{ Top 10} & 0.22 & -0.00 & -0.05 & -0.24 & -0.01 & -0.02 & -0.11 & 0.10 & -0.14 & 0.31 & 0.24 & 0.15 \\
\hline & $(0.90)$ & $(0.65)$ & $(0.61)$ & $(0.66)$ & $(0.49)$ & $(0.63)$ & $(0.59)$ & $(0.54)$ & $(0.57)$ & $(0.88)$ & $(0.72)$ & $(0.93)$ \\
\hline P-Value (Bottom $90=$ Top 10) & 0.06 & 0.04 & 0.12 & 0.02 & 0.22 & 0.04 & 0.01 & 0.20 & 0.06 & 0.03 & 0.04 & 0.03 \\
\hline \multicolumn{13}{|l|}{ Controls } \\
\hline 1) Baseline Cyclicality & $\mathrm{Y}$ & $\mathrm{N}$ & $\mathrm{N}$ & $\mathrm{N}$ & $\mathrm{N}$ & $\mathrm{N}$ & $\mathrm{N}$ & $\mathrm{N}$ & $\mathrm{N}$ & $\mathrm{Y}$ & $\mathrm{Y}$ & $\mathrm{Y}$ \\
\hline 2) Year & $\mathrm{N}$ & $\mathrm{Y}$ & $\mathrm{N}$ & $\mathrm{N}$ & $\mathrm{N}$ & $\mathrm{Y}$ & $\mathrm{Y}$ & $\mathrm{Y}$ & Y & $\mathrm{N}$ & $\mathrm{N}$ & $\mathrm{N}$ \\
\hline 3) $\sigma_{G D P P C}$ Cyclicality & $\mathrm{N}$ & $\mathrm{N}$ & $\mathrm{Y}$ & $\mathrm{N}$ & $\mathrm{N}$ & $\mathrm{N}$ & $\mathrm{N}$ & $\mathrm{N}$ & $\mathrm{N}$ & $\mathrm{N}$ & $\mathrm{N}$ & $\mathrm{N}$ \\
\hline 4) Alternate $\beta$-diff Control \#1 & $\mathrm{N}$ & $\mathrm{N}$ & $\mathrm{N}$ & $\mathrm{Y}$ & $\mathrm{N}$ & $\mathrm{N}$ & $\mathrm{N}$ & $\mathrm{N}$ & $\mathrm{N}$ & $\mathrm{N}$ & $\mathrm{N}$ & $\mathrm{N}$ \\
\hline 5) Alternate $\beta$-diff Control \#2 & $\mathrm{N}$ & $\mathrm{N}$ & $\mathrm{N}$ & $\mathrm{N}$ & $\mathrm{Y}$ & $\mathrm{N}$ & $\mathrm{N}$ & $\mathrm{N}$ & $\mathrm{N}$ & $\mathrm{N}$ & $\mathrm{N}$ & $\mathrm{N}$ \\
\hline 6) Oil Price x State & $\mathrm{N}$ & $\mathrm{N}$ & $\mathrm{N}$ & $\mathrm{N}$ & $\mathrm{N}$ & $\mathrm{Y}$ & $\mathrm{N}$ & $\mathrm{N}$ & $\mathrm{N}$ & $\mathrm{Y}$ & $\mathrm{N}$ & $\mathrm{N}$ \\
\hline 7) Real Interest Rate x State & $\mathrm{N}$ & $\mathrm{N}$ & $\mathrm{N}$ & $\mathrm{N}$ & $\mathrm{N}$ & $\mathrm{N}$ & $\mathrm{Y}$ & $\mathrm{N}$ & $\mathrm{N}$ & $\mathrm{Y}$ & $\mathrm{N}$ & $\mathrm{N}$ \\
\hline 8) Oil Price x State + Region & $\mathrm{Y}$ & $\mathrm{N}$ & $\mathrm{N}$ & $\mathrm{N}$ & $\mathrm{N}$ & $\mathrm{N}$ & $\mathrm{N}$ & $\mathrm{Y}$ & $\mathrm{N}$ & $\mathrm{N}$ & Y & $\mathrm{N}$ \\
\hline 9) Real Interest Rate $x$ State + Region & $\mathrm{N}$ & $\mathrm{N}$ & $\mathrm{N}$ & $\mathrm{N}$ & $\mathrm{N}$ & $\mathrm{N}$ & $\mathrm{N}$ & $\mathrm{N}$ & $\mathrm{Y}$ & $\mathrm{N}$ & $\mathrm{Y}$ & $\mathrm{N}$ \\
\hline 10) State Trends & $\mathrm{N}$ & $\mathrm{N}$ & $\mathrm{N}$ & $\mathrm{N}$ & $\mathrm{N}$ & $\mathrm{N}$ & $\mathrm{N}$ & $\mathrm{N}$ & $\mathrm{N}$ & $\mathrm{N}$ & $\mathrm{N}$ & $\mathrm{Y}$ \\
\hline
\end{tabular}

Notes: Each specification is the same as column 1 in Table 1 other than the controls. The first five columns present different ways to account for state-specific cyclicality (see section 2.1.1 or appendix B.1 for details); (1) baseline specification with cyclicality-quintile by year fixed effects, (2) year fixed effects, (3) cyclicality-quintile by year fixed effects where the quintiles are defined based on the standard deviation in state GDP per capita, (4) cyclicality-decile by year fixed effects, and (5) cyclicality-quintile by year fixed effects that group states only using the years before the sample (i.e., before 1980). The next five columns show controls for state-specific sensitivity to other shocks and trends; (6) controls for oil price interacted with state dummies, (7) controls for real interest rate interacted with state dummies, (8) and (9) add region fixed effects to (6) and (7), and (10) includes state-specific trends. Standard errors are clustered by state $\left({ }^{* * *} \mathrm{p}<0.01,{ }^{* *} \mathrm{p}<0.05,{ }^{*} \mathrm{p}<0.1\right)$ in all specifications other than $(8)$ and $(9)$, which are clustered by region. The sample period is 1980-2007. See appendix A.2 for data definitions and sources. 
Table 3: State-level Effects of Tax Changes by Income Group on Employment: Policy Robustness

\begin{tabular}{|c|c|c|c|c|c|c|c|c|c|c|c|c|}
\hline & $(1)$ & $(2)$ & $(3)$ & $(4)$ & $(5)$ & (6) & $(7)$ & $(8)$ & (9) & $(10)$ & $(11)$ & $(12)$ \\
\hline \multicolumn{13}{|c|}{ Panel A: Distributed Lag Model of Tax Changes for Different Income Groups } \\
\hline$T_{s, t}^{B 90}$ & $\begin{array}{c}0.26 \\
(1.13)\end{array}$ & $\begin{array}{c}0.26 \\
(1.19)\end{array}$ & $\begin{array}{c}0.32 \\
(1.22)\end{array}$ & $\begin{array}{l}-0.11 \\
(1.19)\end{array}$ & $\begin{array}{c}0.21 \\
(1.14)\end{array}$ & $\begin{array}{c}0.18 \\
(1.16)\end{array}$ & $\begin{array}{c}0.18 \\
(1.14)\end{array}$ & $\begin{array}{c}0.50 \\
(1.16)\end{array}$ & $\begin{array}{c}0.36 \\
(1.22)\end{array}$ & $\begin{array}{c}0.09 \\
(1.15)\end{array}$ & $\begin{array}{c}0.36 \\
(1.22)\end{array}$ & $\begin{array}{c}-0.32 \\
(1.03)\end{array}$ \\
\hline$T_{s, t-1}^{B 90}$ & $\begin{array}{c}-2.01^{* *} \\
(0.83)\end{array}$ & $\begin{array}{c}-1.86^{* *} \\
(0.88)\end{array}$ & $\begin{array}{c}-1.83^{* *} \\
(0.91)\end{array}$ & $\begin{array}{l}-1.58 \\
(0.96)\end{array}$ & $\begin{array}{l}-1.67^{*} \\
(0.92)\end{array}$ & $\begin{array}{c}-1.86^{* *} \\
(0.87)\end{array}$ & $\begin{array}{c}-1.90^{* *} \\
(0.87)\end{array}$ & $\begin{array}{l}-1.69^{*} \\
(0.86)\end{array}$ & $\begin{array}{c}-1.85^{* *} \\
(0.90)\end{array}$ & $\begin{array}{c}-2.46^{* *} \\
(0.94)\end{array}$ & $\begin{array}{c}-1.85^{* *} \\
(0.89)\end{array}$ & $\begin{array}{c}-1.86^{* *} \\
(0.84)\end{array}$ \\
\hline$T_{s, t-2}^{B 90}$ & $\begin{array}{l}-1.92 \\
(1.16)\end{array}$ & $\begin{array}{l}-1.99 \\
(1.25)\end{array}$ & $\begin{array}{l}-1.93 \\
(1.29)\end{array}$ & $\begin{array}{l}-1.39 \\
(1.31)\end{array}$ & $\begin{array}{l}-1.96 \\
(1.34)\end{array}$ & $\begin{array}{l}-1.87 \\
(1.16)\end{array}$ & $\begin{array}{l}-2.07 \\
(1.27)\end{array}$ & $\begin{array}{l}-1.86 \\
(1.32)\end{array}$ & $\begin{array}{l}-2.00 \\
(1.25)\end{array}$ & $\begin{array}{c}-2.29^{* *} \\
(1.07)\end{array}$ & $\begin{array}{l}-1.95 \\
(1.24)\end{array}$ & $\begin{array}{l}-1.67 \\
(1.12)\end{array}$ \\
\hline$T_{s, t}^{T 10}$ & $\begin{array}{c}0.43 \\
(0.46)\end{array}$ & $\begin{array}{c}0.52 \\
(0.45)\end{array}$ & $\begin{array}{l}0.53 \\
(0.44)\end{array}$ & $\begin{array}{c}0.47 \\
(0.45)\end{array}$ & $\begin{array}{c}0.54 \\
(0.48)\end{array}$ & $\begin{array}{l}0.67^{*} \\
(0.38)\end{array}$ & $\begin{array}{c}0.51 \\
(0.47)\end{array}$ & $\begin{array}{c}0.49 \\
(0.41)\end{array}$ & $\begin{array}{c}0.53 \\
(0.45)\end{array}$ & $\begin{array}{c}0.48 \\
(0.39)\end{array}$ & $\begin{array}{c}0.54 \\
(0.44)\end{array}$ & $\begin{array}{c}0.44 \\
(0.36)\end{array}$ \\
\hline$T_{s, t-1}^{T 10}$ & $\begin{array}{l}-0.21 \\
(0.56)\end{array}$ & $\begin{array}{l}-0.25 \\
(0.60)\end{array}$ & $\begin{array}{l}-0.24 \\
(0.60)\end{array}$ & $\begin{array}{l}-0.25 \\
(0.58)\end{array}$ & $\begin{array}{l}-0.19 \\
(0.58)\end{array}$ & $\begin{array}{l}-0.13 \\
(0.50)\end{array}$ & $\begin{array}{l}-0.27 \\
(0.62)\end{array}$ & $\begin{array}{l}-0.22 \\
(0.55)\end{array}$ & $\begin{array}{l}-0.23 \\
(0.60)\end{array}$ & $\begin{array}{l}-0.21 \\
(0.50)\end{array}$ & $\begin{array}{l}-0.25 \\
(0.60)\end{array}$ & $\begin{array}{l}-0.14 \\
(0.40)\end{array}$ \\
\hline$T_{s, t-2}^{T 10}$ & $\begin{array}{l}-0.52 \\
(0.61)\end{array}$ & $\begin{array}{l}-0.62 \\
(0.67)\end{array}$ & $\begin{array}{l}-0.62 \\
(0.68)\end{array}$ & $\begin{array}{l}-0.63 \\
(0.66)\end{array}$ & $\begin{array}{l}-0.54 \\
(0.64)\end{array}$ & $\begin{array}{l}-0.59 \\
(0.56)\end{array}$ & $\begin{array}{l}-0.64 \\
(0.68)\end{array}$ & $\begin{array}{l}-0.57 \\
(0.63)\end{array}$ & $\begin{array}{l}-0.60 \\
(0.67)\end{array}$ & $\begin{array}{l}-0.69 \\
(0.56)\end{array}$ & $\begin{array}{l}-0.63 \\
(0.67)\end{array}$ & $\begin{array}{l}-0.55 \\
(0.45)\end{array}$ \\
\hline B90 Sum: $\beta_{t}+\beta_{t-1}+\beta_{t-2}$ & $\begin{array}{l}-3.67^{*} \\
(2.09)\end{array}$ & $\begin{array}{l}-3.59 \\
(2.25)\end{array}$ & $\begin{array}{l}-3.44 \\
(2.32)\end{array}$ & $\begin{array}{l}-3.08 \\
(2.40)\end{array}$ & $\begin{array}{l}-3.42 \\
(2.38)\end{array}$ & $\begin{array}{l}-3.54 \\
(2.17)\end{array}$ & $\begin{array}{l}-3.79^{*} \\
(2.21)\end{array}$ & $\begin{array}{l}-3.05 \\
(2.23)\end{array}$ & $\begin{array}{l}-3.49 \\
(2.30)\end{array}$ & $\begin{array}{c}-4.66^{* *} \\
(2.12)\end{array}$ & $\begin{array}{l}-3.45 \\
(2.29)\end{array}$ & $\begin{array}{l}-3.86^{*} \\
(1.98)\end{array}$ \\
\hline T10 Sum: $\beta_{t}+\beta_{t-1}+\beta_{t-2}$ & $\begin{array}{l}-0.30 \\
(1.47)\end{array}$ & $\begin{array}{l}-0.35 \\
(1.58)\end{array}$ & $\begin{array}{l}-0.33 \\
(1.57)\end{array}$ & $\begin{array}{l}-0.41 \\
(1.55)\end{array}$ & $\begin{array}{l}-0.20 \\
(1.57)\end{array}$ & $\begin{array}{l}-0.05 \\
(1.27)\end{array}$ & $\begin{array}{l}-0.41 \\
(1.63)\end{array}$ & $\begin{array}{l}-0.31 \\
(1.44)\end{array}$ & $\begin{array}{l}-0.31 \\
(1.57)\end{array}$ & $\begin{array}{l}-0.42 \\
(1.29)\end{array}$ & $\begin{array}{l}-0.33 \\
(1.57)\end{array}$ & $\begin{array}{l}-0.25 \\
(1.05)\end{array}$ \\
\hline Bottom - Top: & $\begin{array}{l}-3.37 \\
(2.93)\end{array}$ & $\begin{array}{l}-3.23 \\
(3.14)\end{array}$ & $\begin{array}{l}-3.11 \\
(3.17)\end{array}$ & $\begin{array}{l}-2.67 \\
(3.19)\end{array}$ & $\begin{array}{l}-3.22 \\
(3.23)\end{array}$ & $\begin{array}{l}-3.49 \\
(2.81)\end{array}$ & $\begin{array}{l}-3.38 \\
(3.16)\end{array}$ & $\begin{array}{l}-2.74 \\
(2.96)\end{array}$ & $\begin{array}{l}-3.18 \\
(3.16)\end{array}$ & $\begin{array}{l}-4.24 \\
(2.89)\end{array}$ & $\begin{array}{l}-3.12 \\
(3.13)\end{array}$ & $\begin{array}{l}-3.60 \\
(2.58)\end{array}$ \\
\hline \multicolumn{13}{|c|}{ Panel B: Two-Year Changes } \\
\hline Bottom 90 & $\begin{array}{c}-3.18^{* *} \\
(1.52)\end{array}$ & $\begin{array}{c}-3.35^{* *} \\
(1.51)\end{array}$ & $\begin{array}{c}-3.42^{* *} \\
(1.54)\end{array}$ & $\begin{array}{c}-3.42^{* *} \\
(1.53)\end{array}$ & $\begin{array}{c}-3.62^{* *} \\
(1.53)\end{array}$ & $\begin{array}{c}-3.42^{* *} \\
(1.53)\end{array}$ & $\begin{array}{c}-3.48^{* *} \\
(1.48)\end{array}$ & $\begin{array}{c}-3.37^{* *} \\
(1.53)\end{array}$ & $\begin{array}{c}-3.43^{* *} \\
(1.53)\end{array}$ & $\begin{array}{c}-3.47^{* *} \\
(1.52)\end{array}$ & $\begin{array}{c}-3.42^{* *} \\
(1.54)\end{array}$ & $\begin{array}{c}-3.64^{* *} \\
(1.45)\end{array}$ \\
\hline Top 10 & $\begin{array}{c}0.28 \\
(0.82)\end{array}$ & $\begin{array}{c}0.23 \\
(0.88)\end{array}$ & $\begin{array}{c}0.23 \\
(0.90)\end{array}$ & $\begin{array}{c}0.18 \\
(0.88)\end{array}$ & $\begin{array}{c}0.25 \\
(0.87)\end{array}$ & $\begin{array}{c}0.22 \\
(0.90)\end{array}$ & $\begin{array}{c}0.21 \\
(0.90)\end{array}$ & $\begin{array}{c}0.17 \\
(0.83)\end{array}$ & $\begin{array}{c}0.21 \\
(0.89)\end{array}$ & $\begin{array}{c}0.19 \\
(0.87)\end{array}$ & $\begin{array}{c}0.22 \\
(0.90)\end{array}$ & $\begin{array}{c}0.19 \\
(0.81)\end{array}$ \\
\hline P-Value (Bottom $90=$ Top 10) & 0.07 & 0.06 & 0.06 & 0.06 & 0.04 & 0.06 & 0.05 & 0.06 & 0.06 & 0.06 & 0.06 & 0.04 \\
\hline \multicolumn{13}{|l|}{ Controls } \\
\hline 1) Government Transfers Per Capita & $\mathrm{Y}$ & $\mathrm{N}$ & $\mathrm{N}$ & $\mathrm{N}$ & $\mathrm{N}$ & $\mathrm{N}$ & $\mathrm{N}$ & $\mathrm{N}$ & $\mathrm{N}$ & $\mathrm{N}$ & $\mathrm{N}$ & $\mathrm{N}$ \\
\hline 2) Federal IG Spending Per Capita & $\mathrm{N}$ & $\mathrm{Y}$ & $\mathrm{N}$ & $\mathrm{N}$ & $\mathrm{N}$ & $\mathrm{N}$ & $\mathrm{N}$ & $\mathrm{N}$ & $\mathrm{N}$ & $\mathrm{N}$ & $\mathrm{N}$ & $\mathrm{N}$ \\
\hline 3) Minimum Wage & $\mathrm{N}$ & $\mathrm{N}$ & $\mathrm{Y}$ & $\mathrm{N}$ & $\mathrm{N}$ & $\mathrm{N}$ & $\mathrm{N}$ & $\mathrm{N}$ & $\mathrm{N}$ & $\mathrm{N}$ & $\mathrm{N}$ & $\mathrm{Y}$ \\
\hline 4) OASDI & $\mathrm{N}$ & $\mathrm{N}$ & $\mathrm{N}$ & $\mathrm{Y}$ & $\mathrm{N}$ & $\mathrm{N}$ & $\mathrm{N}$ & $\mathrm{N}$ & $\mathrm{N}$ & $\mathrm{N}$ & $\mathrm{N}$ & $\mathrm{Y}$ \\
\hline 5) Supplemental Security Income & $\mathrm{N}$ & $\mathrm{N}$ & $\mathrm{N}$ & $\mathrm{N}$ & $\mathrm{Y}$ & $\mathrm{N}$ & $\mathrm{N}$ & $\mathrm{N}$ & $\mathrm{N}$ & $\mathrm{N}$ & $\mathrm{N}$ & $\mathrm{Y}$ \\
\hline 6) Max SNAP Benefits & $\mathrm{N}$ & $\mathrm{N}$ & $\mathrm{N}$ & $\mathrm{N}$ & $\mathrm{N}$ & $\mathrm{Y}$ & $\mathrm{N}$ & $\mathrm{N}$ & $\mathrm{N}$ & $\mathrm{N}$ & $\mathrm{N}$ & $\mathrm{Y}$ \\
\hline 7) Medicaid Benefits & $\mathrm{N}$ & $\mathrm{N}$ & $\mathrm{N}$ & $\mathrm{N}$ & $\mathrm{N}$ & $\mathrm{N}$ & $\mathrm{Y}$ & $\mathrm{N}$ & $\mathrm{N}$ & $\mathrm{N}$ & $\mathrm{N}$ & $\mathrm{Y}$ \\
\hline 8) AFDC + TANF Benefits & $\mathrm{N}$ & $\mathrm{N}$ & $\mathrm{N}$ & $\mathrm{N}$ & $\mathrm{N}$ & $\mathrm{N}$ & $\mathrm{N}$ & $\mathrm{Y}$ & $\mathrm{N}$ & $\mathrm{N}$ & $\mathrm{N}$ & $\mathrm{Y}$ \\
\hline 9) Mechanical Change in AFDC \& TANF & $\mathrm{N}$ & $\mathrm{N}$ & $\mathrm{N}$ & $\mathrm{N}$ & $\mathrm{N}$ & $\mathrm{N}$ & $\mathrm{N}$ & $\mathrm{N}$ & $\mathrm{Y}$ & $\mathrm{N}$ & $\mathrm{N}$ & $\mathrm{Y}$ \\
\hline 10) Mechanical Change in SNAP \& SSI & $\mathrm{N}$ & $\mathrm{N}$ & $\mathrm{N}$ & $\mathrm{N}$ & $\mathrm{N}$ & $\mathrm{N}$ & $\mathrm{N}$ & $\mathrm{N}$ & $\mathrm{N}$ & $\mathrm{Y}$ & $\mathrm{N}$ & $\mathrm{Y}$ \\
\hline 11) Mechanical Change in Medicaid & $\mathrm{N}$ & $\mathrm{N}$ & $\mathrm{N}$ & $\mathrm{N}$ & $\mathrm{N}$ & $\mathrm{N}$ & $\mathrm{N}$ & $\mathrm{N}$ & $\mathrm{N}$ & $\mathrm{N}$ & $\mathrm{Y}$ & $\mathrm{Y}$ \\
\hline
\end{tabular}

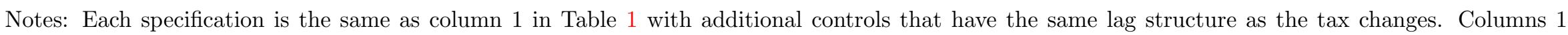

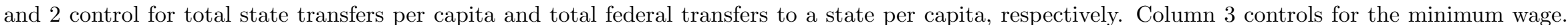

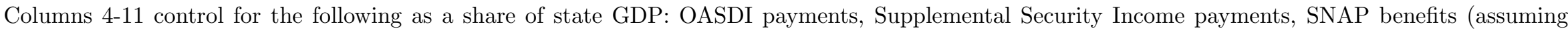

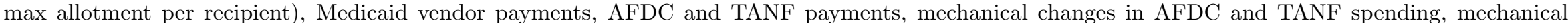

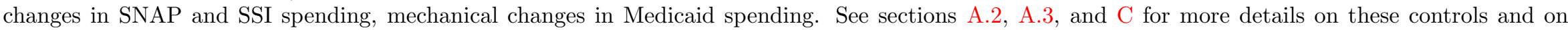

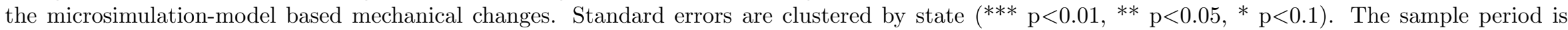
1980-2007. 
Table 4: National Effects of Tax Changes for Different Income Groups

\begin{tabular}{lcccccc}
\hline \hline & GDP & $\underline{\mathrm{I}}$ & $\underline{\text { Res I }}$ & $\underline{\mathrm{C}}$ & $\underline{\text { Dur C }}$ & Non-Dur C \\
& 0.66 & -1.16 & -15.01 & -0.53 & -2.62 & -0.20 \\
B90 & $(1.61)$ & $(7.68)$ & $(11.33)$ & $(1.41)$ & $(5.55)$ & $(1.41)$ \\
& -3.24 & $-15.00^{*}$ & -16.54 & -1.87 & -8.64 & -0.86 \\
B90 2-Year Lag & $(2.17)$ & $(8.54)$ & $(14.49)$ & $(1.69)$ & $(5.83)$ & $(1.41)$ \\
& -1.21 & -11.15 & 1.50 & -0.41 & -4.92 & -0.52 \\
T10 & $(1.99)$ & $(8.41)$ & $(13.51)$ & $(1.82)$ & $(6.75)$ & $(1.42)$ \\
& 1.78 & 6.89 & 2.47 & -0.24 & -0.41 & -1.25 \\
T10 1-Year Lag & $(2.61)$ & $(8.10)$ & $(12.27)$ & $(1.95)$ & $(6.40)$ & $(1.69)$ \\
& -2.13 & -7.77 & -4.53 & -2.28 & -6.31 & -2.45 \\
T10 2-Year Lag & $(2.54)$ & $(11.39)$ & $(12.84)$ & $(2.23)$ & $(8.73)$ & $(2.06)$ \\
& -0.76 & 1.24 & 11.83 & -0.66 & 3.76 & -1.40 \\
B90 Sum: $\beta_{t}+\beta_{t-1}+\beta_{t-2}$ & $(1.26)$ & $(5.34)$ & $(10.08)$ & $(1.25)$ & $(5.41)$ & $(1.41)$ \\
& -3.78 & $-27.30^{*}$ & -30.04 & -2.80 & -16.19 & -1.58 \\
T10 Sum: $\beta_{t}+\beta_{t-1}+\beta_{t-2}$ & $-1.33)$ & $(15.55)$ & $(19.40)$ & $(2.74)$ & $(10.98)$ & $(2.72)$ \\
& $(4.64)$ & $(18.84)$ & $(24.93)$ & -3.18 & -2.96 & -5.11 \\
Bottom - Top: & -2.67 & -27.66 & -39.80 & 0.38 & -13.45 & $(4.23)$ \\
& $(6.64)$ & $(29.24)$ & $(33.39)$ & $(5.77)$ & $(22.45)$ & $(6.53$ \\
\hline \hline
\end{tabular}

Notes: This table presents estimates of the effects of tax changes for different groups $g \in$ \{Bottom 90, Top 10\} at different lags $m$ at the national-level from the following specification: $y_{t}-y_{t-1}=$ $\sum_{m=\underline{m}}^{\bar{m}}\left(\gamma^{B 90, m} T_{t-m}^{B 90}+\gamma^{T 10, m} T_{t-m}^{T 10}+\mathbf{X}_{t-m}^{\prime} \boldsymbol{\Gamma}_{m}\right)+\nu_{t}$, where $y_{t}$ is the log outcome, $T_{t}^{B 90}$ is an exogenous tax shock as a share of national GDP for taxpayers in the bottom $90 \%$ of AGI nationally, and $T_{t}^{B 90}$ is defined analogously. $\mathbf{X}_{t}=\left[T_{N O N I N C, t}\right]$ includes non-income and non-payroll tax changes that Romer and Romer (2010) classify as exogenous. Robust standard errors are reported in parentheses $\left({ }^{* * *} \mathrm{p}<0.01,{ }^{* *} \mathrm{p}<0.05,{ }^{*} \mathrm{p}<0.1\right)$. The sample period is 1950-2007. See section A.2 for data sources. 


\section{Appendices for Online Publication}

This appendix contains several sections. Section A.1 discusses how I measure tax changes in the years before NBER's TAXSIM is available. It also enumerates all of the tax changes and how they are classified. Section A.2 defines all economic variables used in the paper and documents sources. Similarly, section A.3 defines and provides sources for all of the policy and social insurance variables. Section B describes how I construct adjustments for state-specific cyclicality, namely, how I construct $\beta$-differencing cyclicality groups. Section $\mathrm{C}$ describes the social insurance microsimulation models and how they are used to estimate annual state-specific policy-induced changes in social insurance spending.

\section{A Data}

\section{A.1 Tax Data}


Table A1: Post-War Tax Changes

\begin{tabular}{|c|c|c|c|c|}
\hline Legislation & Year & Motivation & Endogeneity & Size (\% GDP) \\
\hline Revenue Act of 1948 & 1948 & Long run & Exogenous & -1.86 \\
\hline Social Security Amendments of 1947 & 1950 & Deficit & Exogenous & 0.26 \\
\hline Internal Revenue Code of 1954 & 1954 & Long run & Exogenous & -0.37 \\
\hline Social Security Amendments of 1958 & 1960 & Deficit & Exogenous & 0.36 \\
\hline Social Security Amendments of 1961 & 1963 & Deficit & Exogenous & 0.86 \\
\hline Revenue Act of 1964 & 1964 & Long run & Exogenous & -1.27 \\
\hline Social Security Amendment of 1967 & 1971 & Deficit & Exogenous & -0.02 \\
\hline Revenue Act of 1971 & 1972 & Long run & Exogenous & -0.73 \\
\hline Tax Reform Act of 1976 & 1976 & Long run & Exogenous & 0.13 \\
\hline Tax Reduction and Simplification Act 1977 & 1977 & Long run & Endogenous & -0.38 \\
\hline 1972 Changes to Social Security & 1978 & Deficit & Exogenous & 0.13 \\
\hline Revenue Act of 1978 & 1979 & Long run & Exogenous & -0.39 \\
\hline Social Security Amendment of 1977 & 1981 & Long run & Exogenous & 0.40 \\
\hline Economic Recovery Tax Act of 1981 & 1982 & Long run & Exogenous & -1.33 \\
\hline Economic Recovery Tax Act of 1981 & 1983 & Long run & Exogenous & -0.87 \\
\hline Social Security Amendments of 1983 & 1984 & Deficit & Exogenous & -0.41 \\
\hline Social Security Amendments of 1983 & 1985 & Deficit & Exogenous & 0.21 \\
\hline Tax Reform Act of 1986 & 1986 & Long run & Exogenous & 0.60 \\
\hline Tax Reform Act of 1986 & 1987 & Long run & Exogenous & -0.57 \\
\hline Social Security Amendments of 1983 & 1988 & Deficit & Exogenous & 0.37 \\
\hline Social Security Amendments of 1983 & 1990 & Deficit & Exogenous & 0.18 \\
\hline Omnibus Budget Reconciliation Act of 1990 & 1991 & Deficit & Endogenous & 0.00 \\
\hline Omnibus Budget Reconciliation Act of 1993 & 1993 & Deficit & Exogenous & 0.42 \\
\hline Omnibus Budget Reconciliation Act of 1993 & 1994 & Deficit & Exogenous & 0.19 \\
\hline Economic Growth and Tax Relief Reconciliation Act of 2001 & 2002 & Long run & Exogenous & -0.77 \\
\hline Jobs and Growth Tax Relief Reconciliation Act of 2003 & 2003 & Long run & Exogenous & -1.13 \\
\hline Jobs and Growth Tax Relief Reconciliation Act of 2003 & 2004 & Long run & Endogenous & 0.00 \\
\hline Jobs and Growth Tax Relief Reconciliation Act of 2003 & 2005 & Long run & Exogenous & 0.54 \\
\hline
\end{tabular}

Notes: This table lists the Romer and Romer (2010) tax changes in the post-war period that are included in the study. The first column provides the legislation for each change. The second provides the year in which the tax change altered tax liabilities. The third column provides the policy motivation from Romer and Romer (2010). The fourth column lists whether the tax change is classified as exogenous. Exogenous is defined as a year in which Romer and Romer (2010) show a nonzero tax change where more than half the revenue was from an exogenous change. Endogenous tax changes are set to zero. The final column reports the size of the tax change as a share of GDP as measured by Romer and Romer (2010). 


\section{A.1.1 Pre-NBER Tax Changes}

Only four exogenous changes, affecting tax liabilities in 1948, 1950, 1954, and 1960, took place in a time preceding the coverage of TAXSIM. For each of these changes, I manually calculated tax changes by income group using the SOI data. ${ }^{43}$ The SOI reports provide data on the number of taxable returns and the amount of taxable income for groups created by size of adjusted gross income. With many AGI brackets, one can form a rough idea of how taxes changed across the income distribution. For each income bracket, I created a representative taxpayer by dividing the amount of taxable income by the number of taxable returns. I then calculated this representative person's change in payroll or federal income tax liability using her income in the year prior to the tax change, the old schedule and the new schedule. Data from the tax schedule were from (2) and (3) for the income tax changes and from (5) for the payroll rate and base changes. For instance, in 1960, any representative taxpayer whose earnings were below the payroll tax base of $\$ 4,800$ had to pay $1 \%$ of their income extra since rates increased from $5 \%$ to $6 \%$. Note that Barrow and Sahasakul (1983) used a somewhat similar approach to calculate average marginal rates.

In general, the following sources were helpful for constructing these tax change measures: (1) the Brooking Institution's "Individual Income Tax Brackets, 1945-2010," (2) the Tax Foundation's "U.S. Federal Individual Income Tax Rates History, 1913-2010," (3) the Internal Revenue Service's annual individual income tax return reports, and (4) the Tax Policy Center's Historical Payroll Tax Rates report. ${ }^{44}$

\section{A.1.2 Tax Change Calculation for Each Tax Return: 1993 Example}

This section provides an example of the tax liability change calculation described in 1.1.1 for 1993. Recall the 1993 Omnibus Budget Reconciliation Act, which raised rates on high-income taxpayers by adding new brackets in 1993 according to the schedule in Table A2. For every taxpayer, my measure subtracts how much she paid in 1992 from how much she would have paid in 1992 if the 1993 tax schedule had been in place. Figure A6 plots the results for 1993. ${ }^{45}$ Many individuals with adjusted gross income above $\$ 100,000$, and especially those with adjusted gross income exceeding $\$ 150,000$, faced a roughly thousand-dollar tax increase based on this measure.

\footnotetext{
43 The 1948 change was from the Revenue Act of 1948, the 1950 change was from the 1947 Social Security Amendment, the 1954 change was from the 1950 Social Security Amendment and the Internal Revenue Code of 1954, and the 1960 change was from the 1958 Social Security Amendment (Romer \& Romer (2009)).

${ }^{44}$ Note that the Tax Policy Center data on the payroll base and rates come from the following two Social Security Administration sites: http://www.ssa.gov/OACT/COLA/cbb.html and http://www.ssa.gov/OACT/ ProgData/taxRates.html.

${ }^{45}$ Note that the 1993 results are based on the sample of 1992 tax returns and the 1992 and 1993 tax schedules.
} 
Table A2: Example of Tax Schedule Change in 1993

\begin{tabular}{|c|c|c|c|c|c|}
\hline \multicolumn{3}{|c|}{1992 Schedule } & \multicolumn{3}{|c|}{1993 Schedule } \\
\hline Tax Rate & Bracket Min & Bracket Max & Marginal Tax Rate & Bracket Min & Bracket Max \\
\hline $15 \%$ & $\$ 0$ & $\$ 35,800$ & $15 \%$ & $\$ 0$ & $\$ 36,900$ \\
\hline $28 \%$ & $\$ 35,800$ & $\$ 86,500$ & $28 \%$ & $\$ 36,900$ & $\$ 89,150$ \\
\hline $31 \%$ & $\$ 86,500$ & - & $31 \%$ & $\$ 89,150$ & $\$ 140,000$ \\
\hline & & & $36 \%$ & $\$ 140,000$ & $\$ 250,000$ \\
\hline & & & $39.6 \%$ & $\$ 250,000$ & - \\
\hline
\end{tabular}

Notes: This table shows the tax schedule in 1992 and 1993 for married taxpayers filing jointly. Extra top brackets were added in 1993. These new brackets mechanically increased tax liabilities for higher-income taxpayers as shown in Figure A6. Tax schedule data are from the Tax Foundation.

\section{A.2 Data on Economic Activity}

1. ACCRA Price Index $P_{s, t}^{A C C R A}$ is the average state price index. Source: The Council for Community and Economic Research; ACCRA Cost of Living Index, 1990-2014. American Chamber of Commerce Researchers Association Index Report, 1980-1989.

2. BLS Price Index. Source: Bureau of Labor Statistics (BLS); Dataset: Consumer Price Index; Variable: Consumer Price Index - All Urban Consumers; Note: Not available for all states. I used population data to allocate city price indexes in cases when a state contained multiple cities with CPI data (e.g., LA and San Francisco for CA's price index).

3. Consumption. Source for state data: U.S. Department of Commerce, Bureau of Economic Analysis; Category: Personal Consumption Expenditures by State, 1997-2014. Source for national data: NIPA Table 1.1.3. Real Gross Domestic Product, Quantity Indexes [Index numbers, $2009=100]$.

4. Dividends, Interest, and Rent. Source: U.S. Department of Commerce, Bureau of Economic Analysis; Category: Regional Economic Accounts; Dataset: State Personal Income Accounts, Annual state personal income and employment, Table SA4.

5. Dividends Income. This variable is the mean pre-tax income received from stocks and mutual funds for those ages 16 or over in a given state-year; see Ruggles et al. (2010). Source: U.S. Census Bureau; Dataset: Current Population Survey, Annual Social and Economic Supplement (ASEC); Variable: incdivid.

6. Disability Benefits Income. This variable is the mean pre-tax income received from disability income for those ages 16 or over in a given state-year; see Ruggles et al. (2010). Source: U.S. Census Bureau; Dataset: Current Population Survey, Annual Social and Economic Supplement (ASEC); Variable: incdisab. 
7. Durable Consumption. Source: NIPA Table 1.1.3. Real Gross Domestic Product, Quantity Indexes [Index numbers, 2009=100].

8. Employment: This variable indicates the number of people employed in a given state-year. Source: Bureau of Labor Statistics, Local Area Unemployment Statistics.

9. Employment Rate. This variable is the share of people, ages 16 or over, in the labor force who report employment status 10 "At work" or 12 "Has job, not at work last week" in the CPS; see Ruggles et al. (2010). Source: U.S. Census Bureau; Dataset: Current Population Survey, Annual Social and Economic Supplement (ASEC).

10. Employment-to-Population Ratio. This variable is the share of people, ages 16 or over, who report employment status 10 "At work" or 12 "Has job, not at work last week" in the CPS; see Ruggles et al. (2010). Source: U.S. Census Bureau; Dataset: Current Population Survey, Annual Social and Economic Supplement (ASEC).

11. FHFA HPI Index. This is a broad measure of the movement of single-family house prices. It measures the average price changes in repeat sales or refinancing on the same properties. Source: Federal Housing Finance Agency House Price Index Datasets, Purchase-Only Indexes (Estimated using Sales Price Data).

12. GDP. Source: NIPA Table 1.1.3. Real Gross Domestic Product, Quantity Indexes [Index numbers, 2009=100].

13. Hours. This variable is the mean hours worked by employed residents in a given state-year given that they worked at least 48 weeks that year and are at least 16 years of age. This variable is constructed using data drawn from the U.S. Census Bureau; Dataset: Current Population Survey, Annual Social and Economic Supplement (ASEC); see Ruggles et al. (2010). I follow Moretti (2013) by restricting the sample to workers aged between 25 and 60 and by using uhrsworkly, wkswork1, and wkswork2 to create a proxy for the number of weeks worked by taking the mean value of wkswork2 in cases where wkswork1 is missing, and call this proxy wkswork. Hours is the product of wkswork and uhrsworkly. I additionally restrict the sample to those who work at least 48 weeks (as determined by the proxy wkswork, described above).

14. Interest Income. This variable is the mean pre-tax income received from interest on savings accounts, certificates of deposit, money market funds, bonds, treasury notes, IRAs, and/or other investments which paid interest for those ages 16 or over in a given state-year; see Ruggles et al. (2010). Source: U.S. Census Bureau; Dataset: Current Population Survey, Annual Social and Economic Supplement (ASEC); Variable: incint.

15. Investment. Source: NIPA Table 1.1.3. Real Gross Domestic Product, Quantity Indexes [Index numbers, 2009=100]. 
16. Labor Force Participation Rate. This variable is the share of persons, ages 16 or over, participating in the labor force; see Ruggles et al. (2010). Source: U.S. Census Bureau; Dataset: Current Population Survey, Annual Social and Economic Supplement (ASEC). This variable is constructed simply from the given indicator "labforce," which is an indicator for whether that person is in the labor force. Those coded "yes" were either: at work; held a job but were temporarily absent due to factors like vacation or illness; seeking work; or were temporarily laid off during the reference period.

17. Moretti CPI Price Index $P_{s, t}^{C P I}$. This variable is a state-specific price index that is constructed following Moretti (2013):

(a) I draw gross monthly rental cost of housing (rentgrs) from the Current Population Survey, Annual Social and Economic Supplement (ASEC).

(b) Housing consumption weights $w_{t}$ are provided by Moretti (2013)\& Yagan (2016). These weights estimate the portion of non-housing costs that vary systematically with housing costs. For reference, this weight is approximately .35 in 2000.

(c) Define $p_{s, t}$ as average gross monthly rental cost of housing by state-year.

(d) Define $r_{s, 1980}$ the average gross monthly rental cost of housing by state in 1980 .

(e) Define $c p i_{t}$ as national CPI from FRED, anchored to 1 in 1980.

(f) Define rental CPI $c p i_{s, t}^{r}=\frac{p_{s, t}}{r_{s, 1980}}$. Let $c p i_{t}^{r}$ be the annual mean of $c p i_{s, t}^{r}$.

(g) Then define $c p i_{t}^{a d j}=\frac{c p i_{t}}{\left(1-w_{t}\right)}-\frac{w_{t}}{\left(1-w_{t}\right)} c p i_{t}^{r}$.

(h) Finally, let $P_{s, t}^{C P I}=\left(1-w_{t}\right)\left(c p i_{t}^{a d j}\right)+w\left(c p i_{s, t}^{r}\right)$.

As noted in Moretti (2013), this measure includes local variation in housing and nonhousing costs, but is limited in that non-housing costs come from national cpi and so that portion of the price index does not vary by state.

18. Moretti HPI Price Index $P_{s, t}^{M o r e t t i}$. This variable is a state-specific price index that is constructed following Moretti (2013). The construction of this variable follows the same steps as "Moretti CPI" above, except I utilize a Housing Price Index (FHFA HPI Index) in place of rentgrs. HPI is drawn from Federal Housing Finance Agency House Price Index Datasets, Purchase-Only Indexes (Estimated using Sales Price Data). See FHFA HPI Index above for a short description of this variable.

19. Net Earnings. Source: U.S. Department of Commerce, Bureau of Economic Analysis; Category: Regional Economic Accounts; Dataset: State Personal Income Accounts, Annual state personal income and employment, Table SA4.

20. Nominal GDP. Source: NIPA Table 1.1.5. 
21. Oil Price. This variable is the average spot price of West Texas Intermediate. Source: St. Louis Federal Reserve FRED database.

22. Part-time Employment Rate. This variable is the share of persons, ages 16 or over, participating in the labor force who report employment status 10 "At work" or 12 "Has job, not at work last week" in the CPS, and also worked fewer than 48 weeks in the past year. I use wkswork1 and wkswork2 to create a proxy for the number of weeks worked by taking the mean value of wkswork 2 in cases where wkswork1 is missing. Each of these variable is drawn from the CPS; see Ruggles et al. (2010). Source: U.S. Census Bureau; Dataset: Current Population Survey, Annual Social and Economic Supplement (ASEC).

23. Payroll. This variable is the total state payroll in a given year. Source: Quarterly Census of Employment and Wages (QCEW) - Statewide.

24. Personal Income. Source: U.S. Department of Commerce, Bureau of Economic Analysis; Category: Regional Economic Accounts; Dataset: State Personal Income Accounts, Annual state personal income and employment, Table SA4.

25. Personal Transfer Receipts. Source: U.S. Department of Commerce, Bureau of Economic Analysis; Category: Regional Economic Accounts; Dataset: State Personal Income Accounts, Annual state personal income and employment, Table SA4.

26. Real Interest Rate. This variable is generated through the Federal Funds Rate less national CPI inflation. Source: St. Louis Federal Reserve FRED database.

27. Rent Income. This variable is the mean pre-tax income received from rent (after expenses) for those ages 16 or over in a given state-year; see Ruggles et al. (2010). Source: U.S. Census Bureau; Dataset: Current Population Survey, Annual Social and Economic Supplement (ASEC); Variable: incrent.

28. Residential Investment. Source: NIPA Table 1.1.3. Real Gross Domestic Product, Quantity Indexes [Index numbers, 2009=100].

29. State GDP. This variable indicates the Gross Domestic Product by state-year. Source: U.S. Department of Commerce, Bureau of Economic Analysis; Category: Regional Economic Accounts; Dataset: Annual Gross Domestic Product (GDP) by State; Series: SIC All GDP Components \& NAICS All GDP Components.

30. State Population. This variable indicates the number of residents in a state-year. Source: Federal Reserve Bank of St. Louis, FRED; Series: Resident Population in state $s$.

31. State GDP/Capita. This variable is state GDP divided by State Population; sources above. 
32. Total Income. This variable is the mean total pre-tax personal income or losses from all sources for those ages 16 or over in a given state-year; see Ruggles et al. (2010). Source: U.S. Census Bureau; Dataset: Current Population Survey, Annual Social and Economic Supplement (ASEC); Variable: inctot.

33. Unemployment Benefit Income. This variable is the mean pre-tax income received from state or federal unemployment compensation, Supplemental Unemployment Benefits (SUB), or union unemployment or strike benefits for those ages 16 or over in a given state-year. Source: U.S. Census Bureau; Dataset: Current Population Survey, Annual Social and Economic Supplement (ASEC); Variable: incunemp.

34. Wage. This variable is the mean wage of full-time workers in a given state-year. This is built utilizing variables from the U.S. Census Bureau; Dataset: Current Population Survey, Annual Social and Economic Supplement (ASEC); see Ruggles et al. (2010). I follow Moretti (2013) in terms of sample restrictions. Specifically, I take wage to be incwage/hours, where incwage comes directly from the CPS and hours is constructed as noted in the item above. In cases in which workers work fewer than 48 weeks per year, as estimated by the wkswork proxy also noted above, I set the wage value to missing so that the state-year measure reflects the average wages of full-time workers as in Moretti (2013). Finally, I restrict the sample to workers aged between 25 and 60 .

35. Welfare Income. This variable is the mean pre-tax income received from various public assistant programs (welfare) for those ages 16 or over in a given state-year; see Ruggles et al. (2010). Source: U.S. Census Bureau; Dataset: Current Population Survey, Annual Social and Economic Supplement (ASEC); Variable: incwelfr.

36. Worker's Compensation Income. This variable is the mean pre-tax income received from worker's compensation payments or other payments as a result of job-related injury or illness for those ages 16 or over in a given state-year; see Ruggles et al. (2010). Source: U.S. Census Bureau; Dataset: Current Population Survey, Annual Social and Economic Supplement (ASEC); Variable: incwkcom.

37. Composition-Constant Wage. I use Ruggles et al. (2010) data on age, sex, education, state, and wages (defined above) from the Integrated Public Use Microdata Series (IPUMS) Annual Social and Economic Supplement (ASEC) of the Current Population Survey (CPS) spanning 1975-2007. I follow the approach of Busso et al. (2013) and Suárez Serrato and Zidar (2016) to construct composition-constant wages in two steps. First, I restrict the sample to full-time workers (i.e., those working at least 48 weeks) who are aged between 25 and 60 and then de-mean wages and worker characteristics (i.e., age, sex, years of education) relative to the whole sample of these workers from 1975-2007 to create a constant reference group across states and years. Second, weighting each observation 
by the supplement weight provided by the CPS, I then estimate the coefficients of the following linear regression model of hourly wages:

$$
\dot{w}_{i, s, t}=\beta_{1} \dot{A} g e_{i, s, t}+\beta_{2} \dot{E} d u c_{i, s, t}+\beta_{3} \dot{M} a l e_{i, s, t}+\mu_{s, t}+u_{i, s, t},
$$

where $i, s$, and $t$ index individuals, states, and years respectively; $\dot{x}$ denotes the demeaned value of the variable $x$; Age is age in years; Educ is approximate ${ }^{46}$ years of education; Male is an indicator for being male; and $\mu_{s, t}$ is a state by year fixed effect. The compositionconstant wage state is the sum of the average wage in the entire sample and the estimated state-year specific average wage, i.e., $\bar{w}_{i, s, t}+\hat{\mu}_{s, t}$.

\section{A.2.1 Real Series}

Real outcomes are the nominal outcomes divided by a specified pricing index. I use the following indices throughout the paper:

1. ACCRA

2. BLS Price Index

\section{Moretti CPI}

\section{Moretti HPI}

The construction and sources of these indices are described in section A.2.

\section{A.2.2 Demographic Groups}

In the appendix of this paper, I present estimates of the effects of tax changes on certain demographic groups. ${ }^{47}$ I only determine outcomes by demographic group if the data originate from the Integrated Public Use Microdata Series (IPUMS) Annual Social and Economic Supplement (ASEC) of the Current Population Survey (CPS); see section A.2. I define these groups as follows:

1. Skilled. Indicates working age people that have at least some college; i.e., educ takes value $80,81,90,91,92,100,110,111,120,121,122,123,124$, or 125.

2. Unskilled. Indicates working-age people with no college, or with education unreported.

3. Aged 25-45. Indicates working-age people aged 25 to 45, exclusive.

\footnotetext{
${ }^{46}$ Specifically, Educ is defined as follows: 0 if educ is $2,2.5$ if educ is 10,1 if educ is 11,2 if educ is 12,3 if educ is 13,4 if educ is $14,5.5$ if educ is 20,5 if educ is 21,6 if educ is $22,7.5$ if educ is 30,7 if educ is 31,8 if educ is 32,9 if educ is 40, 10 if educ is 50, 11 if educ is 60, 12 if inlist(educ, 70, 71, 72, 73), 13 if inlist(educ, 80, 81), 14 if inlist(educ, 90, 91, 92), 15 if educ is 100, 16 if inlist(educ, 110, 111), 17 if inlist(educ, 120, 121), 18 if inlist(educ, 122, 123, 124), 20 if educ is 125, . if inlist(educ, 1, 999).

${ }^{47}$ See appendix Figures A15, A16, A17, A18, A19, A20, and Table A4.
} 
4. Aged 45-60. Indicates working-age people aged 45 to 60 , inclusive.

5. Men. Indicates working-age men. Determined by sex.

6. Women. Indicates working-age women. Determined by sex.

7. White. Indicates working-age people who report their race as white (i.e., race takes value $100)$.

8. Non-White. Indicates working-age people who do not report their race as white.

Note that "working age people" are ages 16 or over, as that is the full sample of reported individuals in the Integrated Public Use Microdata Series (IPUMS) Annual Social and Economic Supplement (ASEC) of the Current Population Survey (CPS).

\section{A.3 Data on Social Insurance}

\section{A.3.1 Controls}

This subsection lists and describes the social insurance variables directly controlled for in regressions.

1. Government Transfers Per Capita. This variable is the total state transfers per capita by state-year. Source: U.S. Department of Commerce, Bureau of Economic Analysis; Category: Regional Economic Accounts; Dataset: State Personal Income Accounts, Annual State Personal Income and Employment, all tables and areas; Series: SA4 19292015 ALL.

2. Federal IG Spending Per Capita. This variable is the total federal transfers to a state per capita by state-year. Source: U.S. Census Bureau's Historical Database on Individual Government Finances.

3. Minimum Wage. This variable is the minimum wage by state-year. Data are from replication files provided by Autor et al. (2016).

4. OASDI. This variable is the ratio of total Old-Age, Survivors, and Disability Insurance (OASDI) payments in a state to that state's GDP. Source: Annual Statistical Supplement to the Social Security Bulletin 1980-2015.

5. Supplemental Security Income. This variable is the ratio of total Supplemental Security Income (SSI) payments in a state to that state's GDP. The total SSI payment in a state is constructed by taking the average federal SSI payment and multiplying that by the number of recipients in a state. Data on federal SSI payments and state recipients are drawn from the Social Security Administration (SSA) - Annual Statistical Supplement to the Social Security Bulletin 1980-2015. 
6. COLA. This variable is the annual cost of living adjustment (COLA) interacted with state dummies. Data on COLA are drawn from the Social Security Administration Database. See: https://www.ssa.gov/oact/cola/SSIamts.html.

7. SNAP Benefits $x$ State. This variable is the ratio of total Supplemental Nutrition Assistance Program (SNAP) Benefits to National GDP. This amount is then interacted with state dummies. Data on SNAP benefits is drawn from the United States Department of Agriculture. See: http://www.fns.usda.gov/pd/supplemental-nutritionassistance-program-snap.

8. Max SNAP Benefits. This variable is the maximum Supplemental Nutrition Assistance Program (SNAP) allotment for families of size 4 multiplied by the number of recipients in that state three years prior and then divided by that state's GDP. Data on SNAP benefits are drawn from the United States Department of Agriculture. See: http://www.fns. usda.gov/pd/supplemental-nutrition-assistance-program-snap.

9. SNAP Benefits Per Household. This variable is the ratio of total Supplemental Nutrition Assistance Program (SNAP) benefits in a state to that state's GDP. Data on SNAP benefits are drawn from the United States Department of Agriculture. See: http://www . fns.usda.gov/pd/supplemental-nutrition-assistance-program-snap.

10. FPL $x$ State. This variable is the federal poverty level for a family of size 4 interacted with state dummies. Source: Social Security Administration, 2015 Annual Statistical Supplement, Data on Social Welfare and the Economy Table 3.E8.

11. FMAP. This variable is the Federal Medical Assistance Percentage (FMAP) for each state. Source: Federal Medical Assistance Percentages, U.S. Department of Health and Human Services.

12. Medicaid Benefits. This variable is the ratio of total Medicaid vendor payments in a state to that state's GDP. Data on state-level recipients and vendor payments is drawn from HFCA-2082 Medicaid State Reports for 1975-1998 and MSIS-2082 Medicaid State Reports for 1999-2012. See: https://www.cms.gov/Research-Statistics-Data-and-Systems/ Computer-Data-and-Systems/MedicaidDataSourcesGenInfo/MSIS-Tables .html.

13. AFDC + TANF Benefits. This variable is the ratio of total AFDC payments in a state to that state's GDP in years prior to 1997. In 1997 and later, this variable takes the ratio of total TANF payments in a state to that state's GDP. Data on AFDC and TANF payments come from the U.S. Department of Health and Human Services Office of Family Assistance. See: http://www.acf.hhs.gov/ofa/resource/afdc-caseload-data1960-1995 and http://www.acf.hhs.gov/ofa/programs/tanf/data-reports. 
14. Max AFDC + TANF Benefits. This variable is the maximum AFDC payment for families with two children multiplied by the number of recipients in that state three years prior and then divided by that state's GDP in years prior to 1997. In 1997 and later, this variable takes the maximum AFDC payment for families of size 3, multiplies this by lagged recipients in a state, and then divides it by that state's GDP. Data on AFDC and TANF payments come from the U.S. Department of Health and Human Services Office of Family Assistance. See: http://www.acf.hhs.gov/ofa/resource/afdc-caseloaddata-1960-1995 and http://www.acf .hhs.gov/ofa/programs/tanf/data-reports.

\section{A.3.2 Policy Parameters for Spending Simulations}

This subsection lists the policy parameters used to simulate social insurance spending.

\section{Aid to Families with Dependent Children (AFDC)}

1. Need Standard, for all family sizes from 1 to 12 . This variable comes from the Transfer Income Model (TRIM3) project website. See: http://trim3.urban.org.

2. Payment Standard, for family sizes from 1 to 12 . This variable comes from the Transfer Income Model (TRIM3) project website. See: http://trim3.urban.org.

3. Maximum Benefit, for family sizes from 1 to 12 . This variable comes from the Transfer Income Model (TRIM3) project website. See: http://trim3.urban.org.

4. Earnings Disregard. This formula is drawn from welfare legislation, namely, the Omnibus Budget Reconciliation Act of 1981, the Deficit Reduction Act of 1984, and the Family Support Act of 1988 .

\section{Temporary Assistance for Needy Families (TANF)}

1. A number of state-specific need standards, payment standards, and maximum benefits, for all family sizes from 1 to 12. These income standards include the Allowable Payment, the Assistance Standard, the Benefit Amount, the Budgetary Adjustment, the Budgetary Standards, the Cash Assistance Monthly Standard, the Consolidated Need Standard, the Family Allowance, the Family Maximum, the Family Size Allowance, the Family Wage Level, the Flat Grant Amount, the Grant Standard, the Maximum Aid Payment, the Maximum Benefit, the Maximum Benefit Payment Schedule, the Maximum Financial Assistance Payment, the Maximum Grant, the Maximum Payment, the Maximum Payment Level, the Maximum Payment Amount, the Need Standard, the Net Income Standard, the Payment Allowance, the Payment Benefit, the Payment Level, the Payment Maximum, the Payment Standard, the Standard of Assistance, the Standard of Need, the TEEM Standard of Need, the Transitional Standard, and the Work Incentive 
Payment. These variables come from the Urban Institute's Welfare Rules Database. See: http://wrd.urban.org/wrd/Query/query.cfm.

2. A number of state-specific variables used as a threshold for the gross income test, for all family sizes from 1 to 12 . These include the Adjusted Standard Needs Budget, the Assistance Standard, the Budgetary Needs Standard, the Budgetary Standards, the Consolidated Need Standard, the Countable Income Limit, the Gross Income Test, the Maximum Benefit Payment Schedule, the Minimum Basic Standard of Adequate Care, the Need Standard, the Net Monthly Income Standard, the Standard of Assistance, the Standard of Need, and the TEEM Standard of Need. These variables come from the Urban Institute's Welfare Rules Database. See: http://wrd.urban.org/wrd/Query/query.cfm.

3. A number of state-specific variables used as a threshold for the net income test, for all family sizes from 1 to 12. These include the Adjusted Income Standard, the Adjusted Standard Needs Budget, the Allocation Allowance Standard, the Allowable Payment, the Benefit Standard, the Budgetary Needs Standard, the Budgetary Standards, the Family Size Allowance, the Flat Grant Amount, the Income Eligibility Standard, the Maximum Benefit, the Minimum Basic Standard of Adequate Care, the Need Standard, the Net Monthly Income Standard, the Payment Level, the Payment Standard, the Recognizable Needs, the Standard of Assistance, the Standard of Need, and the Transitional Standard. These variables come from the Urban Institute's Welfare Rules Database. See: http: //wrd.urban.org/wrd/Query/query.cfm.

4. Maximum Gross Earned Income Limit, which is used as a threshold for the gross earnings test. This variable is available for all family sizes from 1 to 12 and comes from the Urban Institute's Welfare Rules Database. See: http://wrd.urban.org/wrd/Query/ query. cfm.

5. Payment Standard and Standard of Assistance, which are used as a threshold for the unearned income test. These variables are available for all family sizes from 1 to 12 and come from the Urban Institute's Welfare Rules Database. See: http://wrd.urban.org/ wrd/Query/query. cfm.

6. Earnings Disregard for the net income test and benefit computation. These formulae are drawn from the Urban Institute's Welfare Rules Database. See: http://wrd.urban.org/ wrd/Query/query.cfm.

7. Federal Poverty Level (FPL), as defined by the U.S. Department of Health and Human Services. Source: Social Security Administration, 2015 Annual Statistical Supplement, Data on Social Welfare and the Economy Table 3.E8. 


\section{Supplemental Nutrition Assistance Program (SNAP)}

1. Net Income Limit and Gross Income Limit. These variables are multiples (100\% and $130 \%$, respectively) of the Federal Poverty Level, as defined by the Department of Health and Human Services. Source: Social Security Administration, 2015 Annual Statistical Supplement, Data on Social Welfare and the Economy Table 3.E8.

2. Maximum Coupon Allotment. This parameter is set by the U.S. Department of Agriculture. See: https://www.fns.usda.gov/snap/fact-sheet-resources-income-andbenefits.

3. Standard Deduction. This parameter is set by the U.S. Department of Agriculture. See: https://www.fns.usda.gov/snap/fact-sheet-resources-income-and-benefits.

4. Excess Shelter Deduction. This parameter is set by the U.S. Department of Agriculture. See: https://www.fns.usda.gov/snap/fact-sheet-resources-income-andbenefits.

5. Earnings Disregard. Source: U.S. Department of Agriculture. See: https://www.fns . usda.gov/snap/fact-sheet-resources-income-and-benefits.

\section{Supplemental Security Income (SSI)}

1. Monthly Federal Standard for Individuals and Couples. These parameters are set by the Social Security Administration. See: https://www.ssa.gov/oact/cola/SSIamts.html.

2. Earnings and Gross Income Disregards. Source: Social Security Administration. See: https://www.ssa.gov/pubs/EN-05-11015.pdf.

\section{Medicaid}

1. Federal Poverty Level (FPL), as defined by the U.S. Department of Health and Human Services. Source: Social Security Administration, 2015 Annual Statistical Supplement, Data on Social Welfare and the Economy Table 3.E8.

2. Earnings Disregard, which is used to compute countable income for Medicaid from 1997 onwards. This formula comes from the Transfer Income Model (TRIM3) project website. See: http://trim3.urban.org.

3. Income Limit for Children, Elderly, and (section 1931) Parents, as a percentage of the Federal Poverty Level. These parameters are drawn from the Transfer Income Model (TRIM3) project website. See: http://trim3.urban.org. 
4. Age Limit for Children. This parameter is drawn from the Transfer Income Model (TRIM3) project website. See: http://trim3.urban.org.

5. All AFDC parameters, which are used to assess eligibility for low-income families until 1996.

6. All SSI parameters, which are used to assess eligibility for the elderly.

\section{B Empirical Appendix}

\section{B.1 $\beta$-Differences as Cyclicality Controls}

I use $\beta$-differencing for cyclical controls primarily following Blanchard and Katz (1992). I run the following regression for each state $s$ :

$$
\Delta G D P P C_{s, t}=\mu_{s}+\beta_{s} \Delta G D P P C_{t}+\varepsilon_{s, t}
$$

where $G D P P C_{s, t}$ is the logarithm of GDP per capita in state $s$ at time $t$ and $G D P P C_{t}$ is the logarithm of the aggregate national GDP per capita at time $t$. I run this regression on both 19632015. ${ }^{48}$ This produces cyclicality coefficients $\hat{\beta}_{s}$ for each state that measure how responsive the state's economic activity is to changes in national conditions. I then group states into categories based on these coefficients. Specifically, the function $q(s):\{A L, A K, \ldots, W Y\} \rightarrow\{1, \ldots, 5\}$ gives the quintile of the state's sensitivity to national changes in economic conditions. I use these quintiles in the baseline specification but also show results using deciles instead of quintiles in Table 2. Finally, I also show results in Table 2 using quintiles of each state's standard deviation in real GDP per capita $\sigma_{s, 1963-1979}$ in the years preceding the sample period 1980-2007.

\section{Social Insurance Microsimulation Models}

\section{C.1 Overview}

This section describes the social insurance microsimulation models ${ }^{49}$ and how I use them to estimate annual policy-induced changes in social insurance spending for each state. First, I draw individual- and household-level data from IPUMS-CPS and simulate each person's entitlement (if any) to a number of programs, namely, Aid to Families with Dependent Children (AFDC), Temporary Assistance for Needy Families (TANF), Supplemental Nutrition Assistance Program (SNAP), Supplemental Security Income (SSI), and Medicaid. Second, I aggregate individual benefits at the state level and estimate each program's annual spending. Subsequently, for

\footnotetext{
${ }^{48}$ I also present rules only using 1963-1979, i.e., the years the precede the state analysis sample.

${ }^{49}$ Francesco Ruggieri provided extraordinary research assistance on the microsimulation models.
} 
each year and program I perform the same simulation using lagged inputs and current policy parameters, i.e., I estimate each state's spending per program holding constant financial and demographic characteristics, and letting only policy parameters vary. Finally, I construct the one-year, mechanical change in social insurance spending by comparing each program's expenditure in the year preceding a policy rule change to what the state-level spending would have been if the new policy parameters had been in place.

\section{C.1.1 Aid to Families with Dependent Children (AFDC)}

Aid to Families with Dependent Children (AFDC) was the main cash assistance program for lowincome, one-parent families with dependent children. It was replaced by Temporary Assistance for Needy Families (TANF) in 1996, following the enactment of the Personal Responsibility and Work Opportunity Reconciliation Act (PRWORA). My simulation exploits most policy parameters used to determine eligibility, namely, each state's need standard, payment standard, and maximum benefit. For each household, I test whether gross income, i.e., earned and unearned income, and net income are below the threshold for eligibility. Then, I compute the earnings disregard assuming that each family is newly potentially eligible and that child care expense disregards are fully utilized.

\section{C.1.2 Temporary Assistance for Needy Families (TANF)}

Temporary Assistance for Needy Families (TANF) is the cash assistance program for low-income families with dependent children. Following President Clinton's welfare reform in 1996, states currently have broader flexibility - within federal limits - in setting policy parameters and rules, including various income and asset tests for eligibility. My simulation tests whether each household passes a gross income test (if any), a net income test (if any), a gross earnings test (if any), and an unearned income test (if any). Then, I estimate earnings disregards (if any) for the net income test, for TANF benefit computation, or both, assuming that each family has not received TANF benefits before. ${ }^{50}$

\section{C.1.3 Supplemental Nutrition Assistance Program (SNAP)}

The Supplemental Nutrition Assistance Program (SNAP), formerly known as the Food Stamps program, provides coupons to eligible low-income households to help them buy a nutritionally adequate low-cost diet. SNAP policy parameters are set by the U.S. Department of Agriculture, so program rules have little between-state variation. My simulation tests whether gross income, i.e., unearned and earned income, is below the threshold for eligibility. Then, I estimate net ("countable") income by subtracting earnings disregards, a standard deduction, and an excess

\footnotetext{
${ }^{50}$ Because earnings disregards are usually decreasing in the number of months a family has already received cash assistance, this assumption is likely to overstate the true earnings disregard and, subsequently, the TANF monthly benefit.
} 
shelter deduction. In doing so, I assume that households living in non-owned properties pay $30 \%$ of their monthly earnings in rentals. Finally, I compare countable income to the threshold for net income eligibility and determine whether each household is entitled to a positive benefit.

\section{C.1.4 Supplemental Security Income (SSI)}

Supplemental Security Income (SSI) provides cash benefits to aged, blind, or disabled persons with limited income and assets. The main policy parameters are set by the Social Security Administration (SSA), but states can provide supplemental payments and impose additional requirements for benefits other than federal SSI. My simulation follows the definition of "household" as provided by SSI policy rules. Income tests and benefit computation rules are defined for one-person or two-person households (individuals and couples), so my simulation excludes household income not directly accruing to potential SSI recipients. I estimate net ("countable") income by subtracting an earnings disregard from gross income. I test whether this is below the threshold for eligibility and then compute SSI monthly benefit.

\section{C.1.5 Medicaid}

Medicaid provides health insurance for low-income families, children, parents, disabled individuals, and the elderly. Because observations in this paper range from 1980 to 2007, the expansion of Medicaid eligibility to a large number of non-disabled adults provided for by the Affordable Care Act is not taken into account. For each state and year, I estimate the number of individuals eligible for Medicaid through one (or more) of the following channels:

- Aid to Families with Dependent Children (AFDC): until 1996, eligibility for AFDC automatically implied that all family members were entitled to health care coverage under Medicaid. President Clinton's welfare reform delinked Medicaid from eligibility for welfare cash assistance;

- Supplemental Security Income (SSI): elderly and disabled persons eligible for SSI are automatically entitled to Medicaid;

- eligibility for children whose family income is below a state-specific multiple of the federal poverty level;

- eligibility for parents whose family income is below a state-specific multiple of the federal poverty level.

Subsequently, I estimate the state-year level of spending for Medicaid by multiplying the number of eligible adults, elderly, and children by a state- and category-specific average cost provided by the Transfer Income Model (TRIM) from the Urban Institute. 
For all of the social insurance programs described above, I do not test whether countable assets are below the threshold for eligibility because this variable is not available in IPUMS-CPS.

\section{C.2 Policy Parameters and Spending Formulae}

\section{C.2.1 Aid to Families with Dependent Children (AFDC)}

Although the key features of the program did not change between 1980 and 1996, some policy rules were modified following the implementation of three acts: the Omnibus Budget Reconciliation Act of 1981, the Deficit Reduction Act of 1984, and the Family Support Act of 1988. The list of policy rules below applied to AFDC programs in every state in July 1996, when AFDC was replaced by TANF.

\section{Policy Parameters}

- Dependent Children (DC): AFDC was not available for needy families without dependent children.

- Gross Monthly Income (GMI): all of a family's earned and unearned income, after applicable disregards, such as $\$ 50$ a month for child support and optional earned income disregards for certain students.

- Net Monthly Income (NMI): a household's Gross Monthly Income minus the following deductions:

- the Earned Income Tax Credit (EITC);

- \$90 per month for work expenses for individuals employed full- or part-time;

- for an individual who received AFDC in at least one of the prior four months:

* all monthly earned income of a child who is a full-time student or who is a part-time student and not employed full-time;

* \$30 and 1/3 of such person's remaining income for the first four consecutive months, and $\$ 30$ for each of the eight subsequent months;

- for full-time workers:

* actual expenses for dependent care up to $\$ 175$ per month for each dependent child who is at least age 2 or each incapacitated adult;

* up to $\$ 200$ per month for each dependent child who is under age 2 ;

- for part-time workers: a lesser amount could be applicable at state option. 
- Countable Assets (CA): all of a family's assets, excluding the home, one automobile (provided the family member's ownership interest did not exceed a limit chosen by the Secretary of Health and Human Services), burial plots and (up to \$1,500) funeral agreements for each member of the assistance unit.

- Asset Limit (AL): the state-specific threshold for countable assets.

- Need Standard (NS): the income level each State considered essential for basic consumption items. It was increasing in household size.

- Payment Standard (PS): the income level each State used as a threshold for AFDC payments. It was increasing in household size.

- Maximum Monthly Benefit (MMB): the maximum monthly payment, which several states set below the payment standard. It was increasing in household size.

- Household Size (HS).

\section{Spending Estimate}

As of July 1996, AFDC spending per household in a given month in a given state could be expressed as:

$$
\begin{aligned}
A F D C_{h s m}= & I\left[D C_{h s m} \geq 1\right] \\
& I\left[G M I_{h s m} \leq 1.85 \cdot N S_{s m}(H S)\right] . \\
& I\left[N M I_{h s m} \leq N S_{s m}(H S)\right] \\
& I\left[C A_{h s m} \leq A L_{s m}\right] \\
& m i n\left\{P S_{s m}(H S)-N M I_{h s m} ; M M B(H S)\right\},
\end{aligned}
$$

where $I[\cdot]$ is the indicator function, $h$ denotes household, $s$ denotes state of residence, $m$ denotes month, and $y$ denotes year. Thus, AFDC spending in month $m$ in state $s$ can be computed as follows:

$$
A F D C_{s m}=\sum_{h=1}^{H_{s}} A F D C_{h s m}
$$

where $H_{s}$ is the number of households residing in state $s$. It follows that AFDC spending in state $s$ in year $y$ can be expressed as:

$$
A F D C_{s y}=\sum_{m=1}^{12} A F D C_{s m}=\sum_{m=1}^{12} \sum_{h=1}^{H_{s}} A F D C_{h s m}
$$

\section{C.2.2 Temporary Assistance for Needy Families (TANF)}

The Personal Responsibility and Work Opportunity Reconciliation Act (PRWORA) of 1996 gave states broader flexibility in designing their cash assistance programs for families with de- 
pendent children. Matching funds were replaced by a block grant, and states were required to establish a number of job programs in order to smooth the transition between welfare and work.

\section{Policy Parameters}

- Dependent Children (DC): TANF is not available for needy families without dependent children.

- Months of Assistance (MA): federal law prohibits states from providing TANF-funded assistance to individuals in families with an adult who has received assistance for 60 months; states can set lower limits.

- Countable Assets (CA): all of a family's liquid financial assets and other forms of property, excluding the home value. Most states fully or partially disregard the value of vehicles.

- Asset Limit (AL): each state sets a limit on countable assets in order to determine eligibility for TANF.

- Gross Monthly Income (GMI): all of a household's earned and unearned income.

- Net Monthly Income (NMI): a household's gross monthly income minus a number of deductions and/or disregards specified by each State.

- Income Standard (IS), which - depending upon States - is called Need Standard (NS), Payment Standard (PS), Benefit Standard (BS), Income Standard (IS), Transitional Standard (TS), Allowable Payment (AP), Countable Income Limit (CIL), Adjusted Income Standard (AIS), Family Size Allowance (FSA), Standard of Assistance (SA), or Grant Standard (GS). These income thresholds are generally increasing in household size and are set by States in order to:

- determine eligibility based on gross income and/or net income;

- compute benefit amount.

- Federal Poverty Level (FPL), a measure of income issued every year by the Department of Health and Human Services.

- Multiplier for Gross Income Eligibility $\left(\mathrm{M}_{\mathrm{GIE}}\right)$ : the multiplier of each income threshold used to determine gross income eligibility.

- Multiplier for Net Income Eligibility $\left(\mathrm{M}_{\mathrm{NIE}}\right)$ : the multiplier of each income threshold used to determine gross income eligibility. 
- Multiplier for Benefit Computation $\left(\mathbf{M}_{\mathbf{B C}}\right)$ : the multiplier of each income threshold used to compute benefit amount.

- Maximum Monthly Benefit (MMB): the maximum monthly payment, which is adopted by a few states only. It is increasing in household size.

- Flat Benefit (FB): some states provide flat cash assistance benefits, irrespective of household size.

\section{Spending Estimate}

Given the large degree of state flexibility in designing the cash assistance program, TANF spending per household in a given month in a given state can be summarized using three different formulas:

1. Income Standard minus Net Income:

$$
\begin{aligned}
T A N F_{h s m}= & I\left[D C_{h s m} \geq 1\right] . \\
& I\left[M A_{h} \leq 60\right] . \\
& I\left[G M I_{h s m} \leq M_{G I E} \cdot I S_{s m}(H S)\right] \\
& I\left[N M I_{h s m} \leq M_{N I E} \cdot I S_{s m}(H S)\right] . \\
& I\left[C A_{h s m} \leq A L_{s m}\right] \cdot \\
& \left(M_{B C} \cdot I S_{s m}(H S)-N M I_{h s m}\right)
\end{aligned}
$$

2. Income Standard minus Net Income, within Maximum Monthly Benefit:

$$
\begin{aligned}
T A N F_{h s m}= & I\left[D C_{h s m} \geq 1\right] \cdot \\
& I\left[M A_{h} \leq 60\right] \cdot \\
& I\left[G M I_{h s m} \leq M_{G I E} \cdot I S_{s m}(H S)\right] \cdot \\
& I\left[N M I_{h s m} \leq M_{N I E} \cdot I S_{s m}(H S)\right] \cdot \\
& I\left[C A_{h s m} \leq A L_{s m}\right] \cdot \\
& \min \left\{M_{B C} \cdot I S_{s m}(H S)-N M I_{h s m} ; M M B(H S)\right\}
\end{aligned}
$$

3. Flat Benefit:

$$
\begin{aligned}
T A N F_{h s m}= & I\left[D C_{h s m} \geq 1\right] . \\
& I\left[M A_{h} \leq 60\right] . \\
& I\left[G M I_{h s m} \leq M_{G I E} \cdot I S_{s m}(H S)\right] \cdot \\
& I\left[N M I_{h s m} \leq M_{N I E} \cdot I S_{s m}(H S)\right] \cdot \\
& I\left[C A_{h s m} \leq A L_{s m}\right] .
\end{aligned}
$$$$
F B
$$ 
where $I[\cdot]$ is the indicator function, $h$ denotes household, $s$ denotes state of residence, $m$ denotes month, and $y$ denotes year. Thus, TANF spending in month $m$ in state $s$ can be computed as follows:

$$
T A N F_{s m}=\sum_{h=1}^{H_{s}} T A N F_{h s m},
$$

where $H_{s}$ is the number of households residing in state $s$. It follows that TANF spending in state $s$ in year $y$ can be expressed as:

$$
T A N F_{s y}=\sum_{m=1}^{12} T A N F_{s m}=\sum_{m=1}^{12} \sum_{h=1}^{H_{s}} T A N F_{h s m}
$$

\section{C.2.3 Supplemental Nutrition Assistance Program (SNAP)}

SNAP policy rules and parameters were almost left unchanged between 1980 and 2007. A gross income test was required for eligibility starting in 1983 and the dependent care deduction was capped starting in 1986. Policy parameters as of July 2007 are described below.

\section{Policy Parameters}

- Gross Monthly Income (GMI): all of a household's cash income except a number of disregards.

- Net Monthly Income (NMI) : a household's Gross Monthly Income minus the following deductions:

- Standard Deduction: a "standard" monthly deduction which varies by household size and is indexed for inflation;

- Earned Income Deduction: 20\% of any earned income, in recognition of taxes and work expenses;

- Child Support Deduction: any amounts paid out as legally obligated child support;

- Dependent Care Deduction: out-of-pocket dependent care expenses, when related to work or training;

- Excess Shelter Deduction: shelter expenses (including utility costs) that exceed $50 \%$ of net income after all other deductions, typically expenses that exceed about onethird of gross monthly income. The excess shelter deduction does not vary upon household size.

- Countable Assets (CA): a household's assets, including cash on hand, checking and savings accounts, savings certificates, stocks and bonds, a portion of the value of vehicles.

- Asset Limit (AL): the threshold for countable assets. 
- Maximum Monthly Allotment (MMA): this is increasing in household size and is based upon the level of the U.S. Department of Agriculture's lowest-cost food plan.

- Federal Poverty Level (FPL): a measure of income issued every year by the Department of Health and Human Services. This is higher in Alaska and Hawaii.

- Household Size (HS).

\section{Spending Estimate}

As of 2007, SNAP spending per household in a given month in a given state can be expressed as:

$$
\begin{aligned}
S N A P_{h s m}= & I\left[G M I_{h s m} \leq 1.3 \cdot F P L_{s y}(H S)\right] \\
& I\left[N M I_{h s m} \leq F P L_{s y}(H S)\right] \\
& I\left[C A_{h s m} \leq A L_{s m}\right] \\
& \left(M M A_{s y}(H S)-0.3 \cdot N M I_{h s m}\right)
\end{aligned}
$$

where $I[\cdot]$ is the indicator function, $h$ denotes household, $s$ denotes state of residence, $m$ denotes month, and $y$ denotes year. Thus, SNAP spending in month $m$ in state $s$ can be computed as follows:

$$
S N A P_{s m}=\sum_{h=1}^{H_{s}} S N A P_{h s m},
$$

where $H_{s}$ is the number of households residing in state $s$. It follows that SNAP spending in state $s$ in year $y$ can be expressed as:

$$
S N A P_{s y}=\sum_{m=1}^{12} S N A P_{s m}=\sum_{m=1}^{12} \sum_{h=1}^{H_{s}} S N A P_{h s m}
$$

\section{C.2.4 Supplemental Security Income (SSI)}

SSI policy rules and parameters underwent no change in the time period considered in this paper.

\section{Policy Parameters}

- Household Size (HS): this can take value 1 or 2, because SSI benefits are available for individuals or couples.

- Gross Monthly Income (GMI): all of a household's cash income, consisting of both earnings and unearned income (such as other social insurance payments).

- Net Monthly Income (NMI): a household's Gross Monthly Income minus the following deductions: 
- the first $\$ 20$ of non-needs-based monthly income from virtually any source;

- the first $\$ 32.5$ in monthly earnings;

- $50 \%$ of the remaining monthly earnings: this income disregard is provided as an incentive to undertake work activities.

- Countable Assets (CA): a household's assets, excluding an individual's home, the entire value of an automobile used for essential transportation, any property essential to income-producing activity, and household goods and personal effects totaling $\$ 2,000$ or less.

- Asset Limit (AL): the threshold for countable assets; this is higher for couples than for individuals.

- Maximum Net Monthly Income (MNMI): this is increasing in household size and is based upon the Federal Poverty Level, issued every year by the Department of Health and Human Services. Because some states provide supplemental payments to SSI, the effective maximum net monthly income varies across states.

\section{Spending Estimate}

SSI spending per household in a given month in a given state can be expressed as:

$$
\begin{aligned}
S S I_{h s m}= & I\left[N M I_{h s m} \leq M N M I_{s y}(H S)\right] \\
& I\left[C A_{h s m} \leq A L_{s m}\right] . \\
& \left(M N M I_{s y}(H S)-N M I_{h s m}\right),
\end{aligned}
$$

where $I[\cdot]$ is the indicator function, $h$ denotes household, $s$ denotes state of residence, $m$ denotes month, and $y$ denotes year. Thus, SSI spending in month $m$ in state $s$ can be computed as follows:

$$
S S I_{s m}=\sum_{h=1}^{H_{s}} S S I_{h s m}
$$

where $H_{s}$ is the number of households residing in state $s$. It follows that SSI spending in state $s$ in year $y$ can be expressed as:

$$
S S I_{s y}=\sum_{m=1}^{12} S S I_{s m}=\sum_{m=1}^{12} \sum_{h=1}^{H_{s}} S S I_{h s m}
$$

\section{C.2.5 Medicaid}

Because Medicaid does not provide recipients with cash benefits, the policy parameters described below are used to determine one's eligibility for Medicaid through each of the paths set by federal and state law. 


\section{Policy Parameters}

\section{Eligibility through Aid to Families with Dependent Children (until 1996):}

- Dependent Children (DC): AFDC was not available for needy families without dependent children.

- Gross Monthly Income (GMI): all of a family's earned and unearned income, after applicable disregards, such as $\$ 50$ a month for child support and optional earned income disregards for certain students.

- Net Monthly Income (NMI): a household's Gross Monthly Income minus the following deductions:

- the Earned Income Tax Credit (EITC);

- \$90 per month for work expenses for individuals employed full- or part-time;

- for an individual who received AFDC in at least one of the prior four months:

* all monthly earned income of a child who is a full-time student or who is a part-time student and not employed full-time;

* $\$ 30$ and $1 / 3$ of such person's remaining income for the first four consecutive months, and $\$ 30$ for each of the eight subsequent months;

- for full-time workers:

* actual expenses for dependent care up to $\$ 175$ per month for each dependent child who is at least age 2 or each incapacitated adult;

* up to $\$ 200$ per month for each dependent child who is under age 2;

- for part-time workers: a lesser amount could be applicable at state option.

- Countable Assets (CA): all of a family's assets, excluding the home, one automobile (provided the family member's ownership interest did not exceed a limit chosen by the Secretary of Health and Human Services), burial plots and (up to $\$ 1,500$ ) funeral agreements for each member of the assistance unit.

- Asset Limit (AL): the state-specific threshold for countable assets.

- Need Standard (NS): the income level each State considered essential for basic consumption items. It was increasing in household size.

- Household Size (HS).

\section{Eligibility through Supplemental Security Income:}

- Household Size (HS): this can take value 1 or 2, because SSI benefits are available for individuals or couples.

- Gross Monthly Income (GMI): all of a household's cash income, consisting of both earnings and unearned income (such as other social insurance payments). 
- Net Monthly Income (NMI): a household's Gross Monthly Income minus the following deductions:

- the first $\$ 20$ of non-needs-based monthly income from virtually any source;

- the first $\$ 32.5$ in monthly earnings;

- $50 \%$ of the remaining monthly earnings: this income disregard is provided as an incentive to undertake work activities.

- Countable Assets (CA): a household's assets, excluding an individual's home, the entire value of an automobile used for essential transportation, any property essential to income-producing activity, and household goods and personal effects totaling $\$ 2,000$ or less.

- Asset Limit (AL): the threshold for countable assets; this is higher for couples than for individuals.

- Maximum Net Monthly Income (MNMI): this is increasing in household size and is based upon the Federal Poverty Level, issued every year by the Department of Health and Human Services. Because some states provide supplemental payments to SSI, the effective maximum net monthly income varies across states.

\section{Eligibility for Children and Parents:}

- Gross Monthly Income (GMI): all of a household's earnings and unearned income.

- Net Monthly Income (NMI): until 1996, Net Monthly Income for Medicaid used to be determined according to AFDC rules. Following the Personal Responsibility and Work Opportunity Reconciliation Act (PRWORA), which delinked AFDC eligibility from Medicaid, Net Monthly Income calculation rules involved a state-specific earnings disregard as well as a deduction in recognition of child care expenses and a child support deduction.

- Countable Assets (CA): all of a household's countable resources, as defined by federal and state law.

- Asset Limit (AL): the state-specific threshold for countable assets.

- Federal Poverty Level (FPL): a measure of income issued every year by the Department of Health and Human Services. This is higher in Alaska and Hawaii.

- Children's Income Limit Multiplier $\left(\mathbf{M}_{\mathbf{C H}}\right)$ : the Federal Poverty Level multiplier used to determine income eligibility for children.

- Parents' Income Limit Multiplier $\left(\mathbf{M}_{\mathbf{P A}}\right)$ : the Federal Poverty Level multiplier used to determine income eligibility for parents.

- Household Size (HS). 


\section{Spending Estimate}

Medicaid is a dummy variable which takes value 1 if all conditions for eligibility are met.

1. Eligibility through Aid to Families with Dependent Children (until 1996). As of July 1996, Medicaid eligibility through AFDC can be expressed as:

$$
\begin{aligned}
M E D_{h s m}^{A F D C}= & I\left[D C_{h s m} \geq 1\right] . \\
& I\left[G M I_{h s m} \leq 1.85 \cdot N S_{s m}(H S)\right] . \\
& I\left[N M I_{h s m} \leq N S_{s m}(H S)\right] . \\
& I\left[C A_{h s m} \leq A L_{s m}\right],
\end{aligned}
$$

where $I[\cdot]$ is the indicator function, $h$ denotes household, $s$ denotes state of residence, $m$ denotes month, and $y$ denotes year.

2. Eligibility through Supplemental Security Income. Medicaid eligibility through SSI can be expressed as:

$$
\begin{aligned}
M E D_{h s m}^{S S I}= & I\left[N M I_{h s m} \leq M N M I_{s y}(H S)\right] \\
& I\left[C A_{h s m} \leq A L_{s m}\right]
\end{aligned}
$$

where $I[\cdot]$ is the indicator function, $h$ denotes household, $s$ denotes state of residence, $m$ denotes month, and $y$ denotes year.

\section{Eligibility for Children}

$$
\begin{aligned}
M E D_{h s m}^{C H}= & I\left[N M I_{h s m} \leq M_{C H} \cdot F P L_{s y}(H S)\right] \\
& I\left[C A_{h s m} \leq A L_{s m}\right]
\end{aligned}
$$

where $I[\cdot]$ is the indicator function, $h$ denotes household, $s$ denotes state of residence, $m$ denotes month, and $y$ denotes year.

\section{Eligibility for Parents}

$$
\begin{aligned}
M E D_{h s m}^{P A}= & I\left[N M I_{h s m} \leq M_{P A} \cdot F P L_{s y}(H S)\right] \\
& I\left[C A_{h s m} \leq A L_{s m}\right]
\end{aligned}
$$

where $I[\cdot]$ is the indicator function, $h$ denotes household, $s$ denotes state of residence, $m$ denotes month, and $y$ denotes year.

Medicaid spending in month $m$ in state $s$ can be estimated by multiplying the number of eligible individuals by the average health care expense per Medicaid recipient (labeled as AVG):

$$
M E D_{s m}=A V G_{s m} \cdot \sum_{h=1}^{H_{s}} M E D_{h s m}
$$


where $H_{s}$ is the number of households residing in state $s$. It follows that Medicaid spending in state $s$ in year $y$ can be expressed as:

$$
M E D_{s y}=\sum_{m=1}^{12} M E D_{s m}=\sum_{m=1}^{12} A V G_{s m} \cdot \sum_{h=1}^{H_{s}} M E D_{h s m} .
$$

\section{C.3 Actual and Simulated Spending for Social Insurance Programs}

This section shows how simulated social insurance spending at the state level compares to actual data. All states and the District of Columbia are included, and observations range from 1980 to 2007. 
Figure A1: Actual vs. Simulated Spending for AFDC

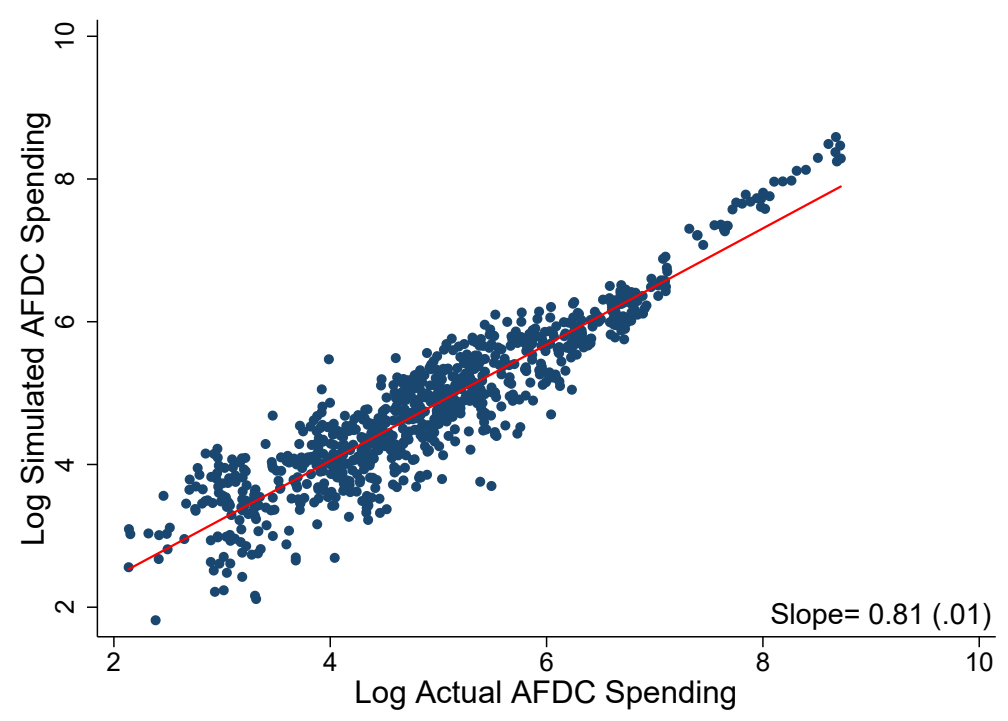

Notes: This figure shows the log of actual AFDC spending against the log of simulated AFDC spending. The data are at the state-year level from 1980 to 1996. See appendix C for more details on the construction of these spending estimates.

Figure A2: Actual vs. Simulated Spending for TANF

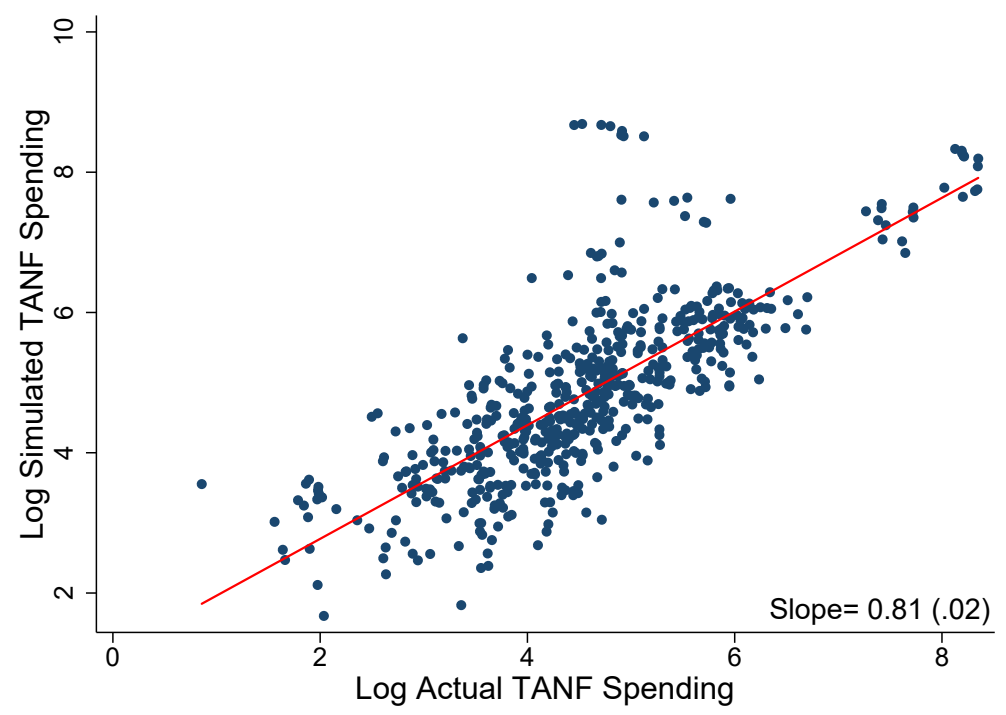

Notes: This figure shows the log of actual TANF spending against the log of simulated TANF spending. The data are at the state-year level from 1997 to 2007. See appendix C for more details on the construction of these spending estimates. 
Figure A3: Actual vs. Simulated Spending for SSI

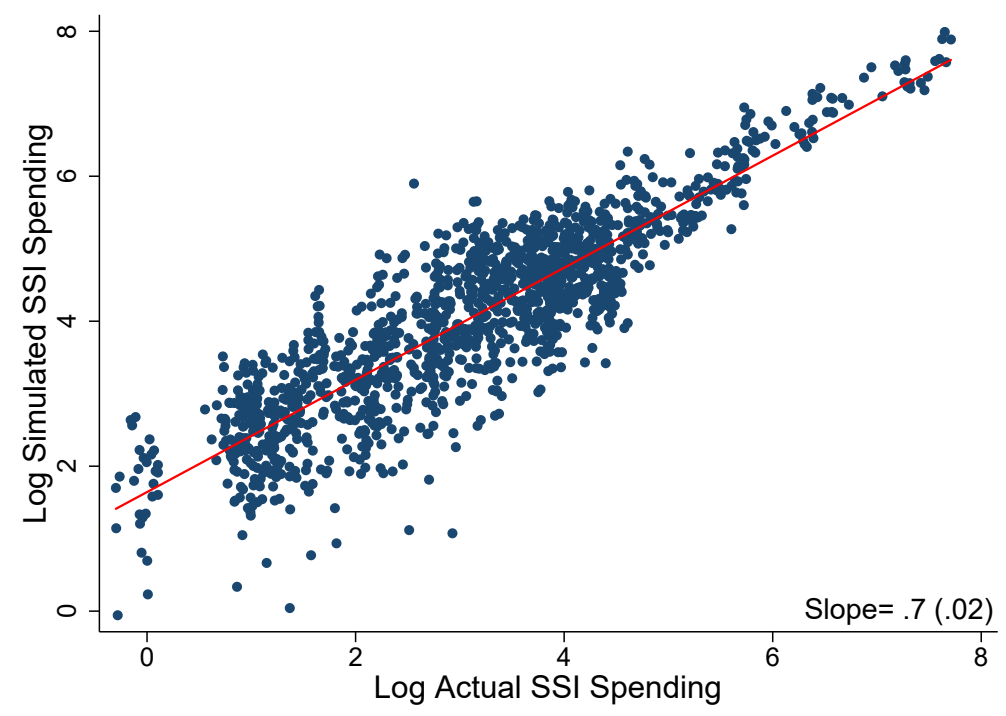

Notes: This figure shows the log of actual SSI spending against the log of simulated SSI spending. The data are at the state-year level from 1980 to 2007. See appendix C for more details on the construction of these spending estimates.

Figure A4: Actual vs. Simulated Spending for SNAP

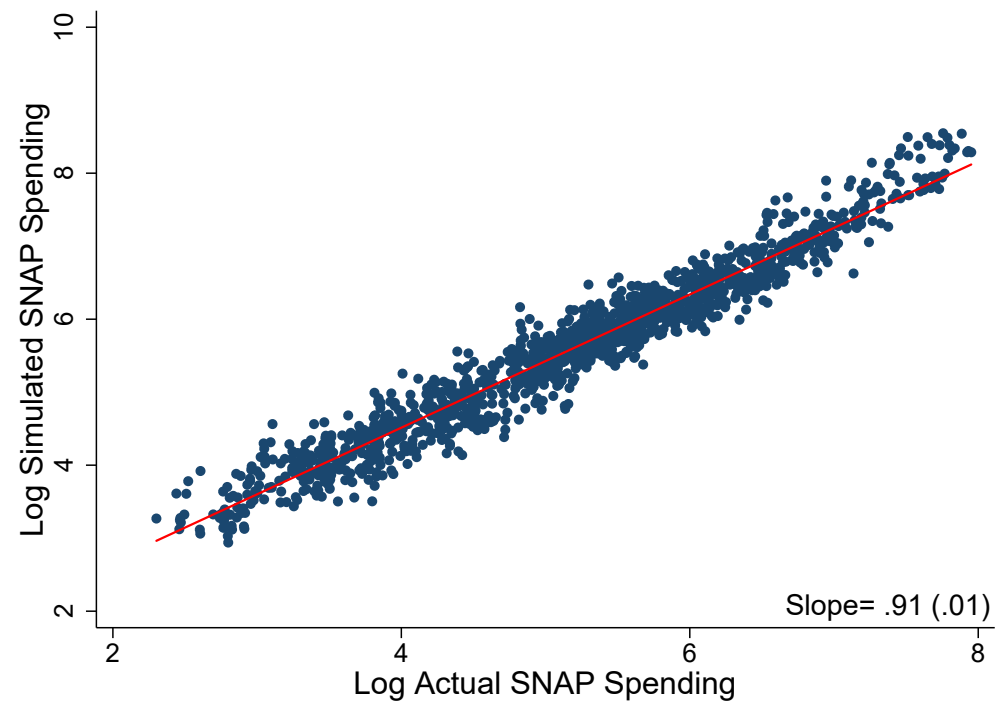

Notes: This figure shows the log of actual SNAP spending against the log of simulated SNAP spending. The data are at the state-year level from 1980 to 2007. See appendix C for more details on the construction of these spending estimates. 
Figure A5: Actual vs. Simulated Spending for Medicaid

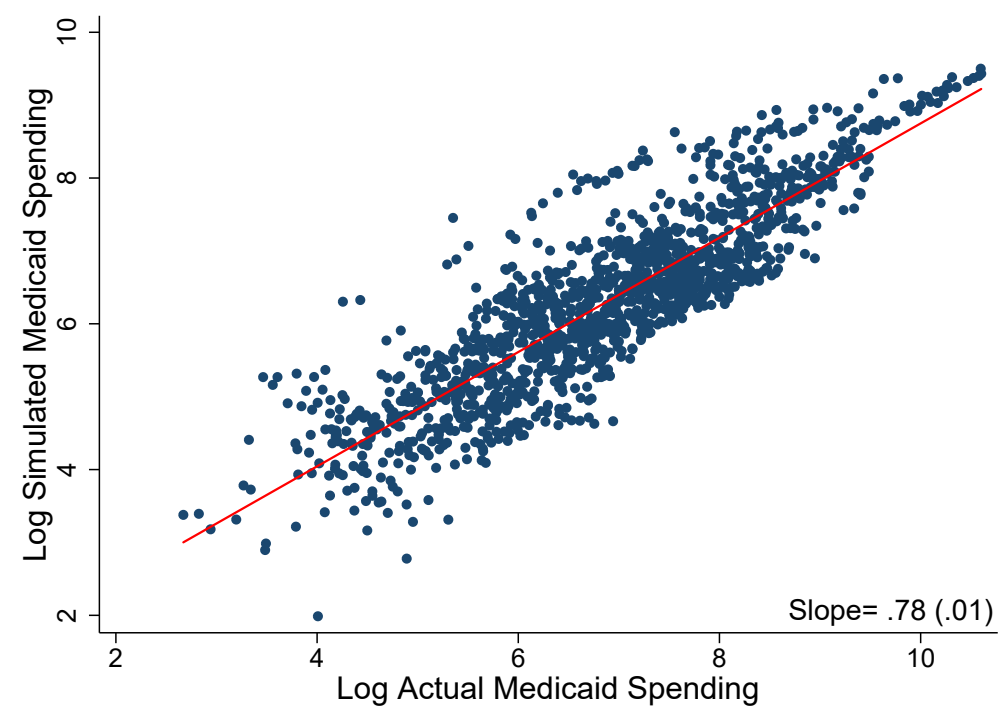

Notes: This figure shows the log of actual Medicaid spending against the log of simulated Medicaid spending. The data are at the state-year level from 1980 to 2007. See appendix C for more details on the construction of these spending estimates. 
Figure A6: Tax Change Calculation for Each Tax Return: 1993 Example

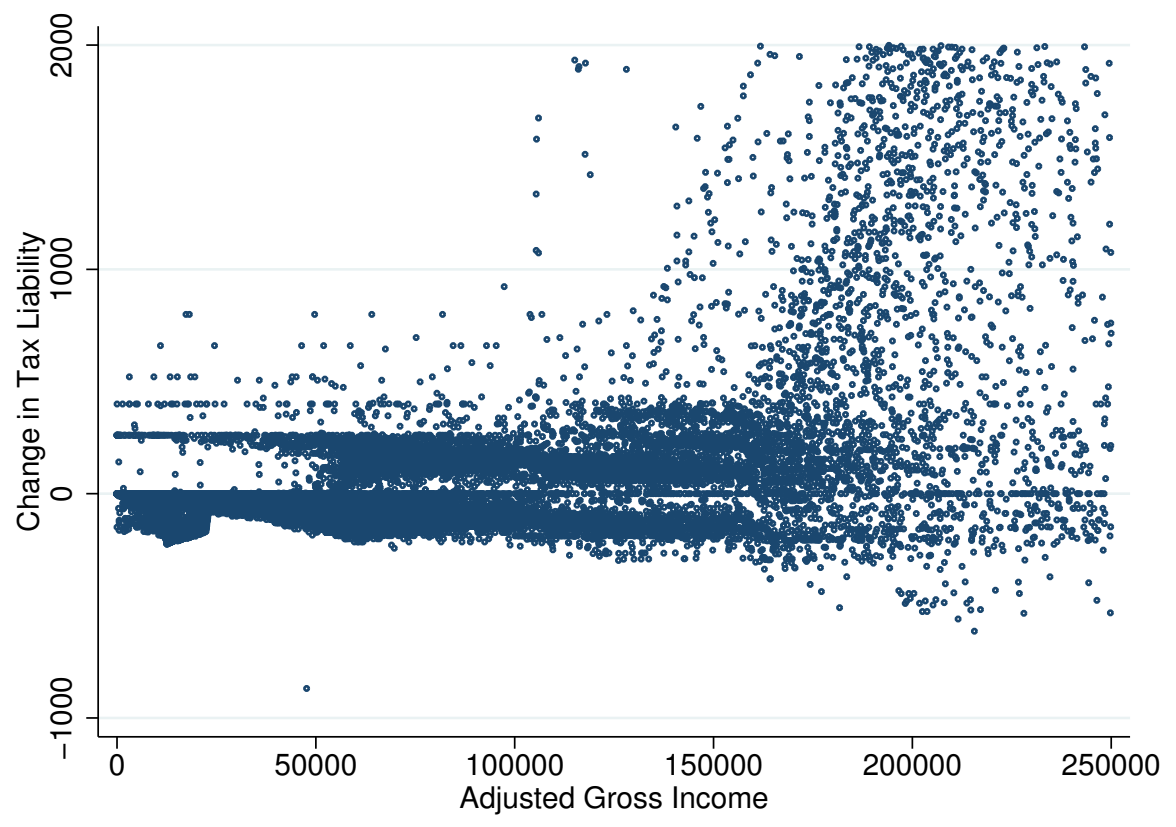

Notes: This figure displays the mechanical change in income and payroll tax liability for each tax return in TAXSIM from tax schedule changes in 1993 by AGI. For display purposes, it shows results for tax changes for $0<A G I<250 K$ and $|\Delta \operatorname{Tax}|<2,000$. 
Figure A7: Comparison of Aggregate Tax Changes with Romer \& Romer Changes

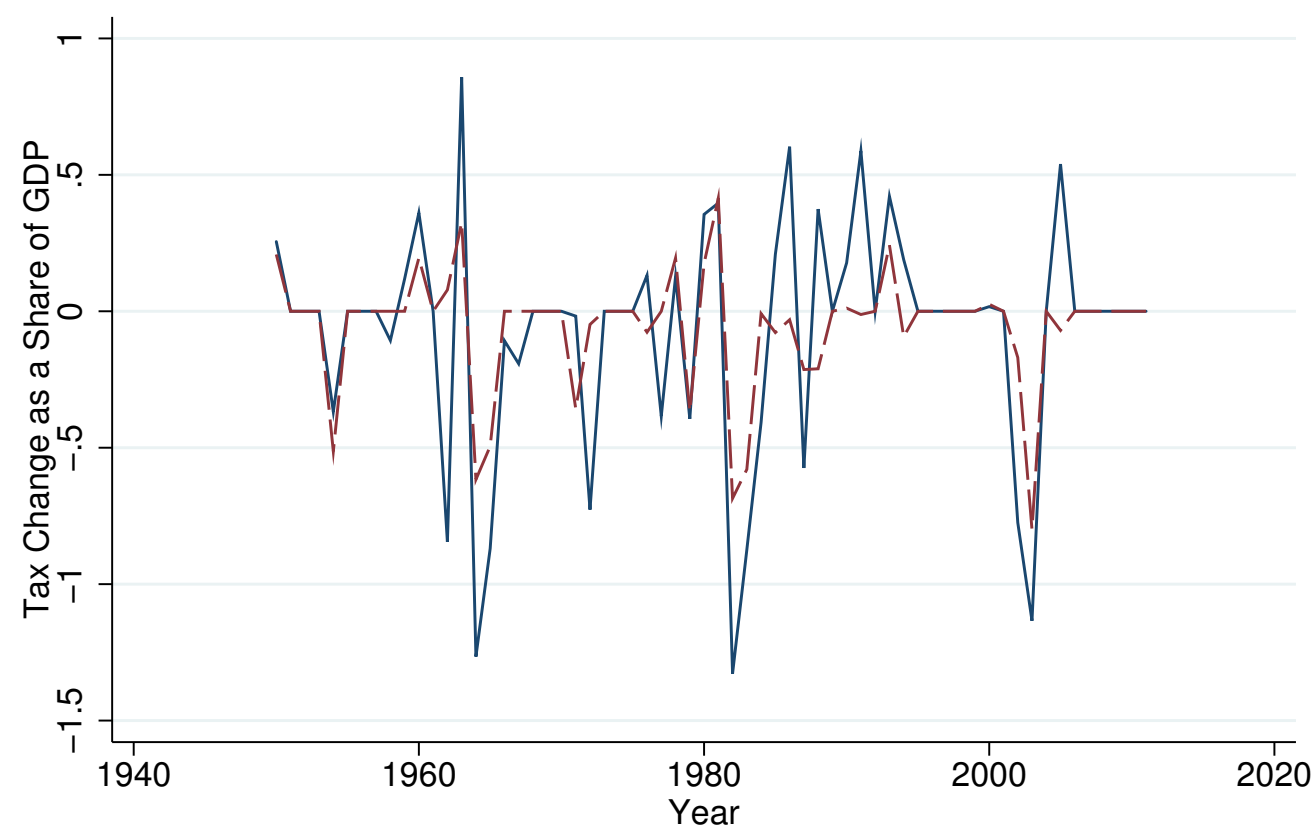

Romer Tax Measure $\quad---$ Income and Payroll Tax Changes

Notes: This figure shows two postwar time series of tax changes: (1) the sum of all income and payroll tax changes that Romer and Romer (2010) classify as exogenous and (2) the exogenous tax change measures of Romer and Romer (2010). Both series are as a share of GDP. Some of the Romer and Romer (2010) tax changes affect corporate taxes and other revenue sources, but the two series track each other fairly closely. 
Figure A8: Favero and Giavazzi Orthogonality Test for Both Tax Change Series

\section{A. Tax Changes for Top $10 \%$}

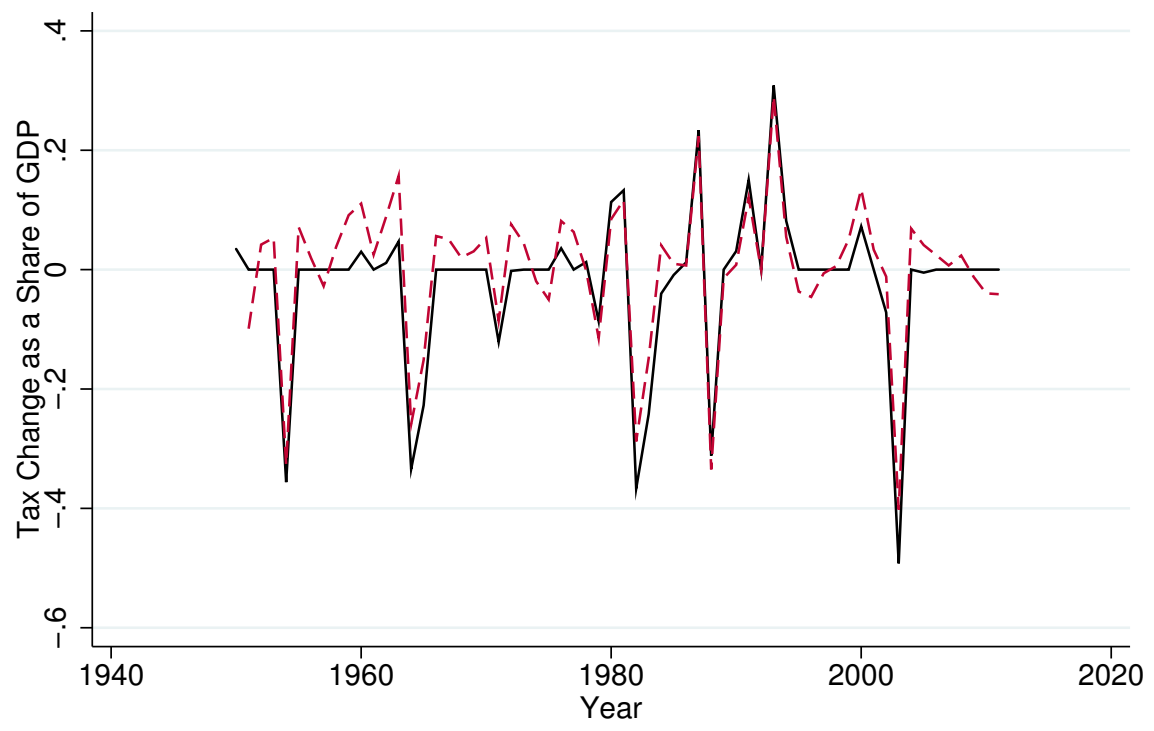

Top 10\% Tax Shock - - - Orthogonalized Top 10\% Tax Shock

B. Tax Changes for Bottom 90\%

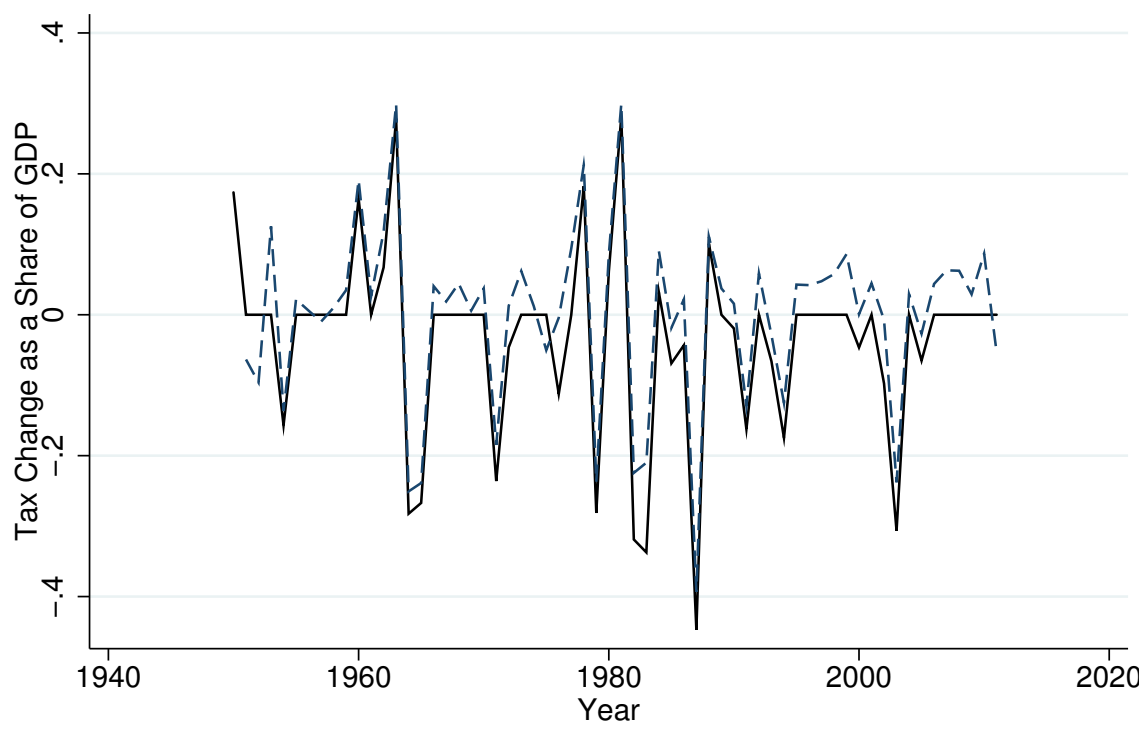

Bot. 90\% Tax Shock - - - Orthogonalized Bot. 90\% Tax Shock

Notes: This figure plots the raw time series of federal income and payroll tax changes as a share of GDP as well as an orthogonalized time series of the residual of the tax change measure after partialling out lagged macro aggregates, which are annual log changes in employment, inflation, government transfers as a share of GDP, and federal debt as a share of GDP. The graphs show that the orthogonalized version is quite similar to the raw time series, suggesting that these federal tax shock series for the top $10 \%$ and bottom $90 \%$ both pass the Favero and Giavazzi (2012) orthogonality test. See data section for sources and section 3.4 for additional discussion. 
Figure A9: Frisch Waugh Regression: Tax Changes for Top versus Bottom

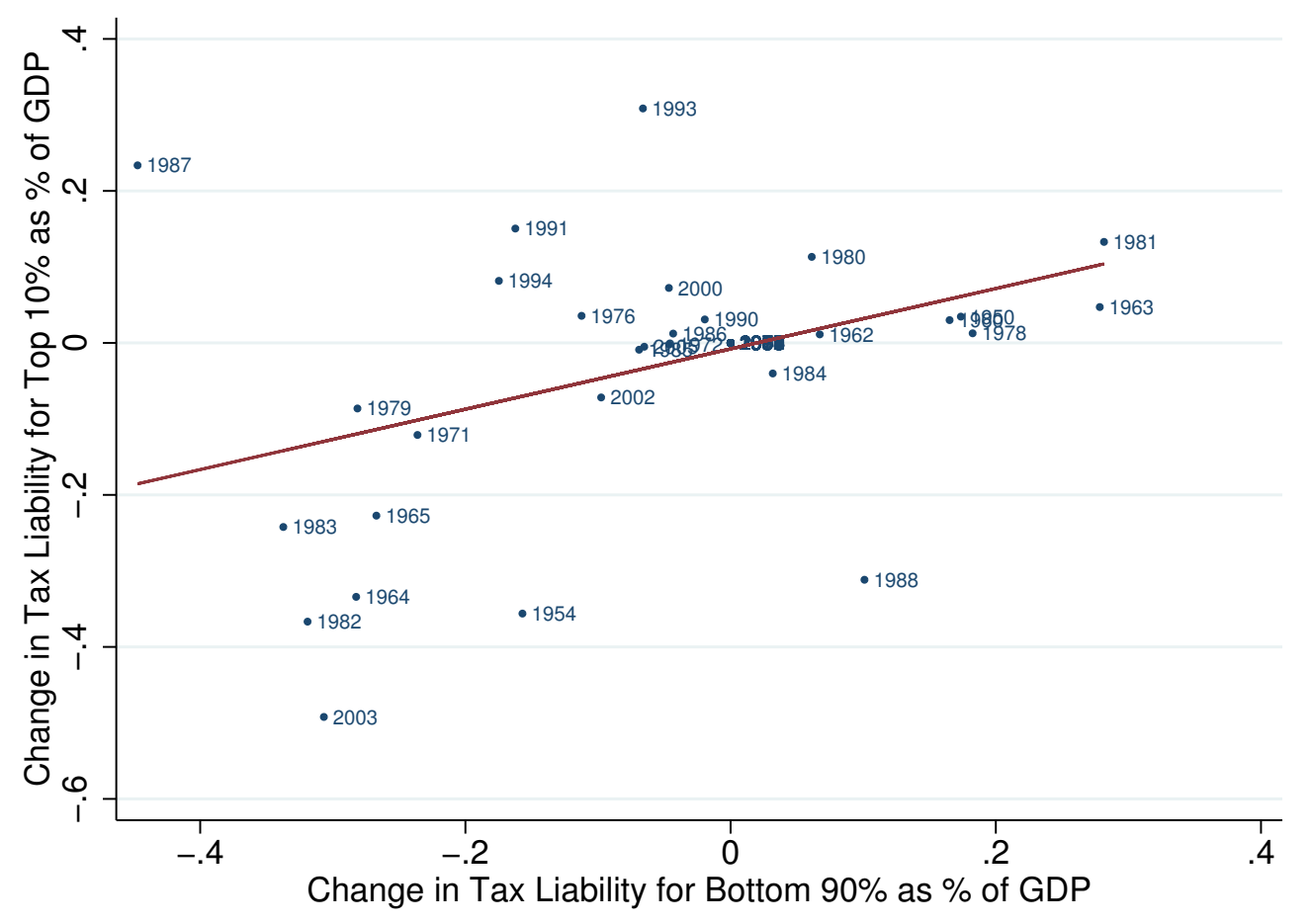

Notes: This figure plots exogenous tax changes for those with AGI in top $10 \%$ by those for the bottom $90 \%$. Both tax changes are as a share of output. The figure also plots the predicted value of exogenous tax changes for those in the top $10 \%$ from a simple bivariate regression on exogenous tax changes for those with AGI in the bottom $90 \%$. Years that fall below the best fit line had tax changes that went disproportionately to the top $10 \%$ (given the magnitude of tax changes for the bottom $90 \%$ as a share of output). 
Figure A10: Cumulative Growth in Emp-to-Pop Ratio and Employment: Lagged Tax Changes as Controls

A. Employment/Population

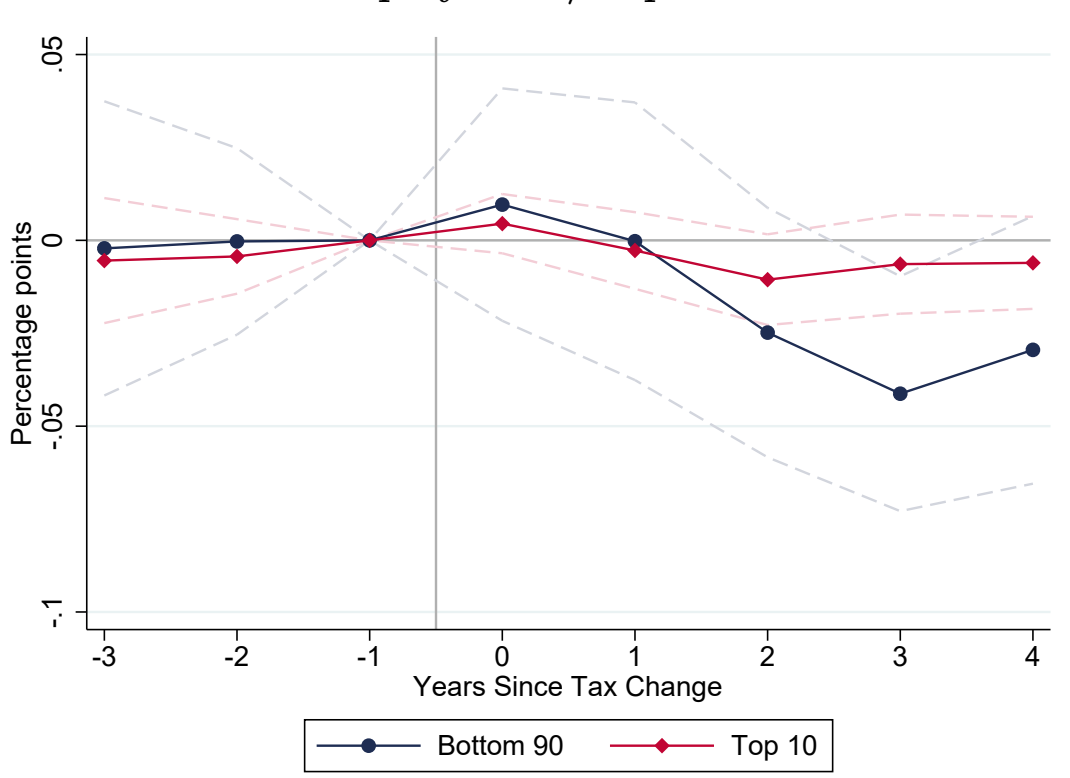

B. Employment

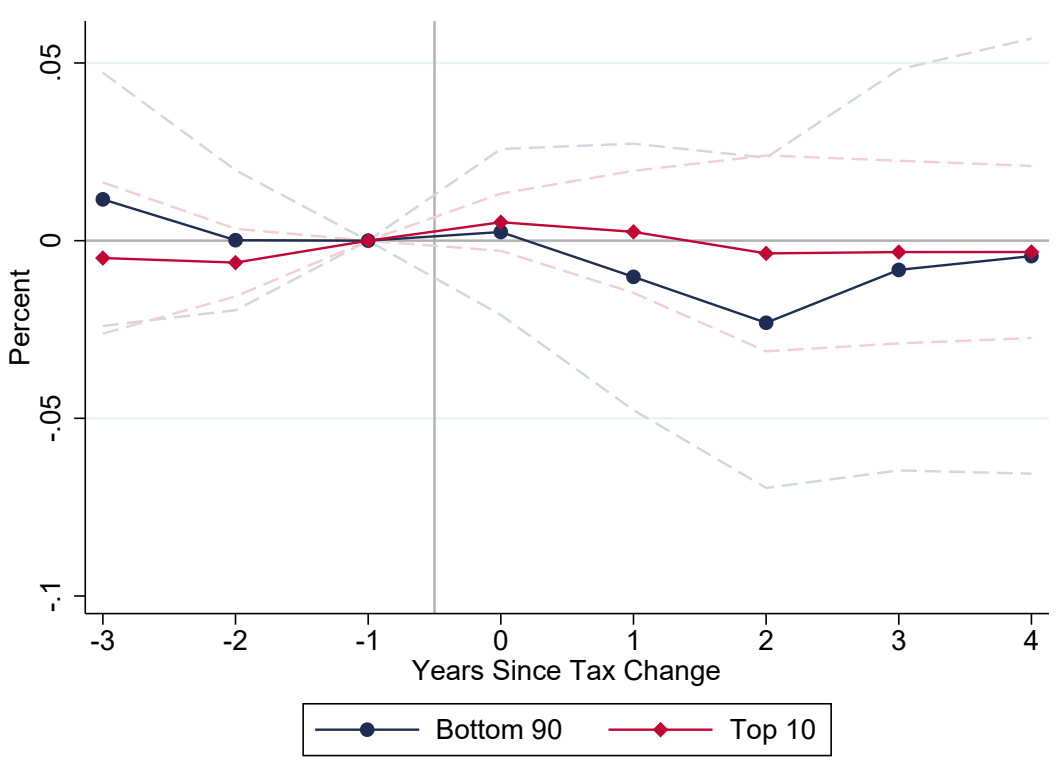

Notes: This figure shows event studies of a $1 \%$ of GDP tax increase on the state employment-to-population ratio and employment for those with AGI in the bottom $90 \%$ nationally in blue and for those with AGI in the top $10 \%$ nationally in red. Specifically, the figure plots the estimates from the baseline specification of equation 2 for the impact of tax changes in year $h$ for the bottom $90 \%, \hat{\alpha}_{h}^{B 90}$, and the top $10 \%, \hat{\alpha}_{h}^{T 10}$. The baseline specification includes controls for mechanical changes in AFDC, TANF, SNAP, SSI, and Medicaid spending as a percentage of state GDP, as well as cyclicality-quintile year fixed effects. See section 2 for details. One and two year lags of tax changes and spending controls are also included. Standard errors are robust and clustered by state; $95 \%$ confidence intervals are shown as dotted lines. The sample period is 1980-2007. 
Figure A11: Cumulative Growth in Prices, GDP, and Earnings: Lagged Tax Changes as Controls
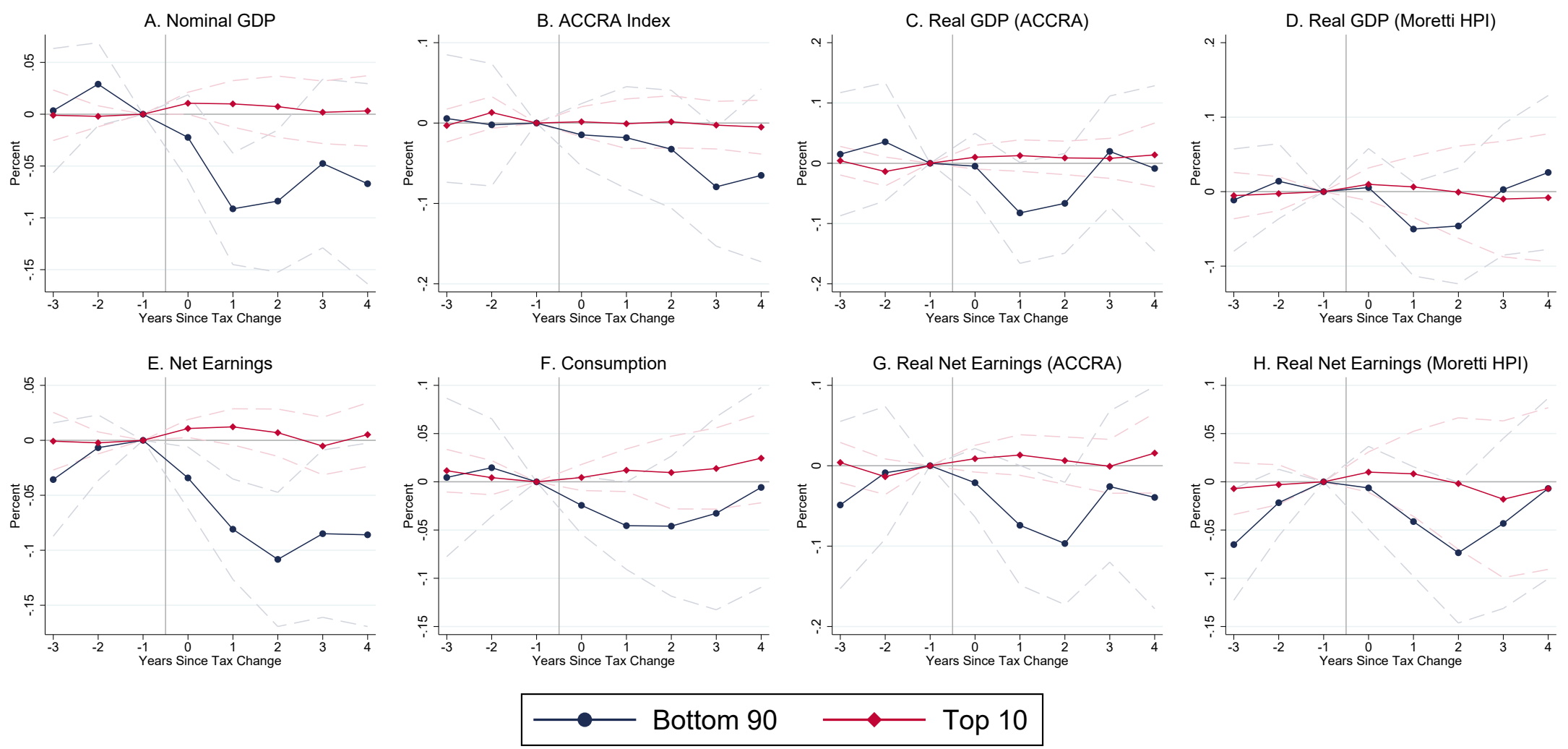

Notes: This figure shows event studies of a $1 \%$ of GDP tax increase on outcomes for those with AGI in the bottom $90 \%$ nationally in blue and for those with AGI in the top 10\% nationally in red. The outcomes are (a) nominal state GDP, (b) the ACCRA state price index $P_{s, t}^{A C C R A}$, (c) real state GDP using $P_{s, t}^{A C C R A}$, (d) real state GDP using $P_{s, t}^{M o r e t t i}$, (e) nominal net earnings, (f) consumption, (g) real net earnings using $P_{s, t}^{A C C R A}$, and (h) real net earnings using $P_{s, t}^{M o r e t t i}$. Specifically, the figure plots the estimates from the baseline specification of equation 2 for the impact of tax changes in year $h$ for the bottom $90 \%, \hat{\alpha}_{h}^{B 90}$, and the top $10 \%, \hat{\alpha}_{h}^{T 10}$. The baseline specification includes controls for mechanical changes in AFDC, TANF, SNAP, SSI, and Medicaid spending as a percentage of state GDP, as well as cyclicality-quintile year fixed effects. See section 2 for details. One and two year lags of tax changes and spending controls are also included. Standard errors are robust and clustered by state; $95 \%$ confidence intervals are shown as dotted lines. The sample period is 1980-2007 for (a)-(e) and (g)-(h). However, state consumption is only available since 1997, so the sample period for (f) is 1997-2007. 
Figure A12: Cumulative Growth in State-level Labor Market Outcomes: Lagged Tax Changes as Controls
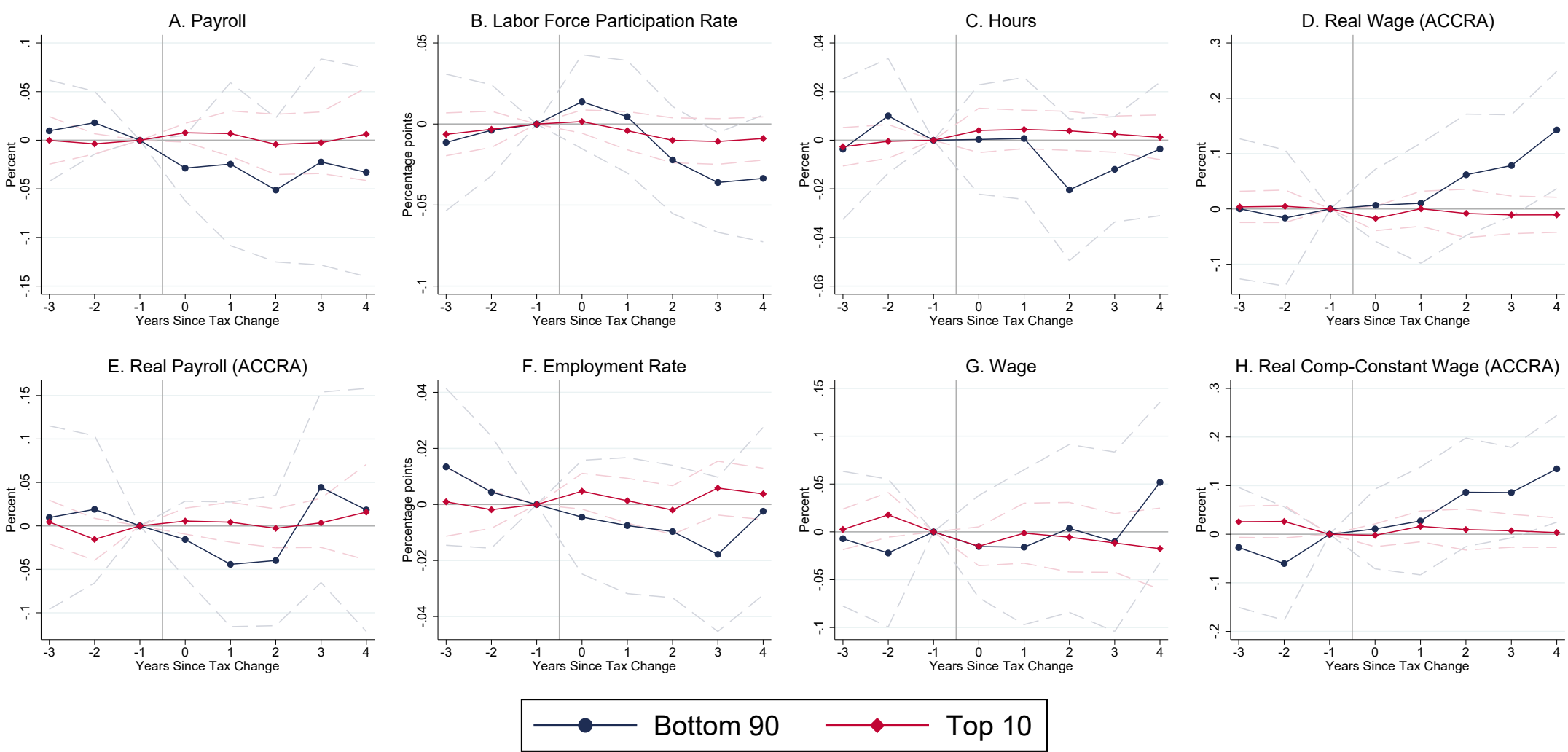

Notes: This figure shows event studies of a $1 \%$ of GDP tax increase on outcomes for those with AGI in the bottom $90 \%$ nationally in blue and for those with AGI in the top $10 \%$ nationally in red. These outcomes are (a) nominal state payroll, (b) labor force participation rate, (c) mean hours worked among those who worked at least 48 weeks in the past year, (d) mean real wages using $P_{s, t}^{A C C R A}$, (e) real state payroll using $P_{s, t}^{A C C R A}$, (f) employment rate, (g) mean wages, and (h) real composition-constant average wages using $P_{s, t}^{A C C R A}$. Specifically, the figure plots the estimates from the baseline specification of equation 2 for the impact of tax changes in year $h$ for the bottom $90 \%, \hat{\alpha}_{h}^{B 90}$, and the top $10 \%, \hat{\alpha}_{h}^{T 10}$. The baseline specification includes controls for mechanical changes in AFDC, TANF, SNAP, SSI, and Medicaid spending as a percentage of state GDP, as well as cyclicality-quintile year fixed effects. See section 2 for details. One and two year lags of tax changes and spending controls are also included. Standard errors are robust and clustered by state; $95 \%$ confidence intervals are shown as dotted lines. The sample period is 1980-2007. 
Figure A13: Cumulative Growth in Prices

A. BLS Price Index

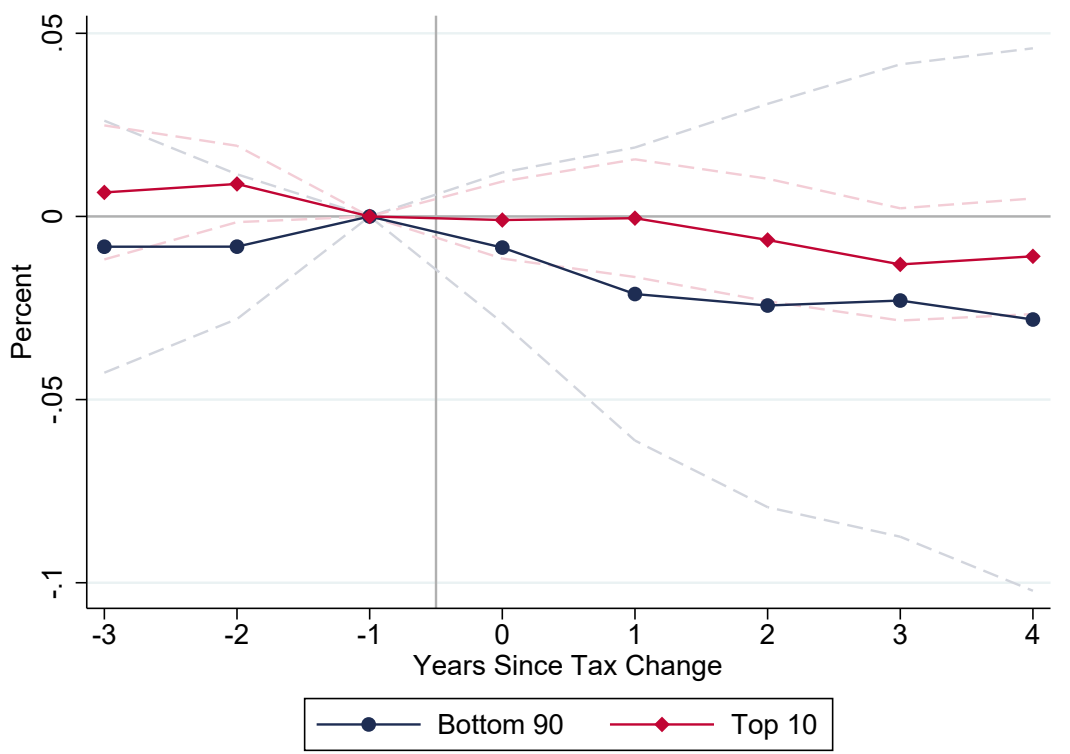

B. Moretti HPI Index

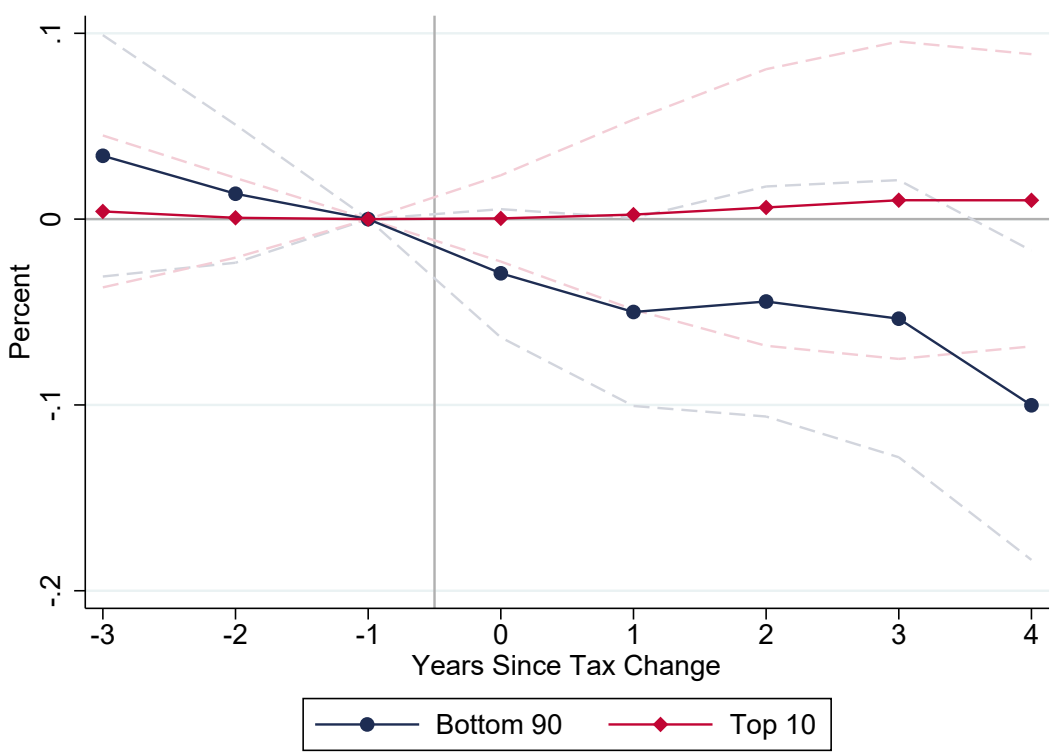

Notes: This figure shows event studies of a $1 \%$ of GDP tax increase on the BLS price index and Moretti HPI index $P_{s, t}^{M o r e t t i}$ for those with AGI in the bottom $90 \%$ nationally in blue and for those with AGI in the top $10 \%$ nationally in red. Specifically, the figure plots the estimates from the baseline specification of equation 2 for the impact of tax changes in year $h$ for the bottom $90 \%, \hat{\alpha}_{h}^{B 90}$, and the top 10\%, $\hat{\alpha}_{h}^{T 10}$. The baseline specification includes controls for mechanical changes in AFDC, TANF, SNAP, SSI, and Medicaid spending as a percentage of state GDP, as well as cyclicality-quintile year fixed effects. See section 2 for details. Standard errors are robust and clustered by state; $95 \%$ confidence intervals are shown as dotted lines. The sample period is $1980-2007$. 
Figure A14: Cumulative Growth in State-level Real Wages

A. Real Wage (BLS)

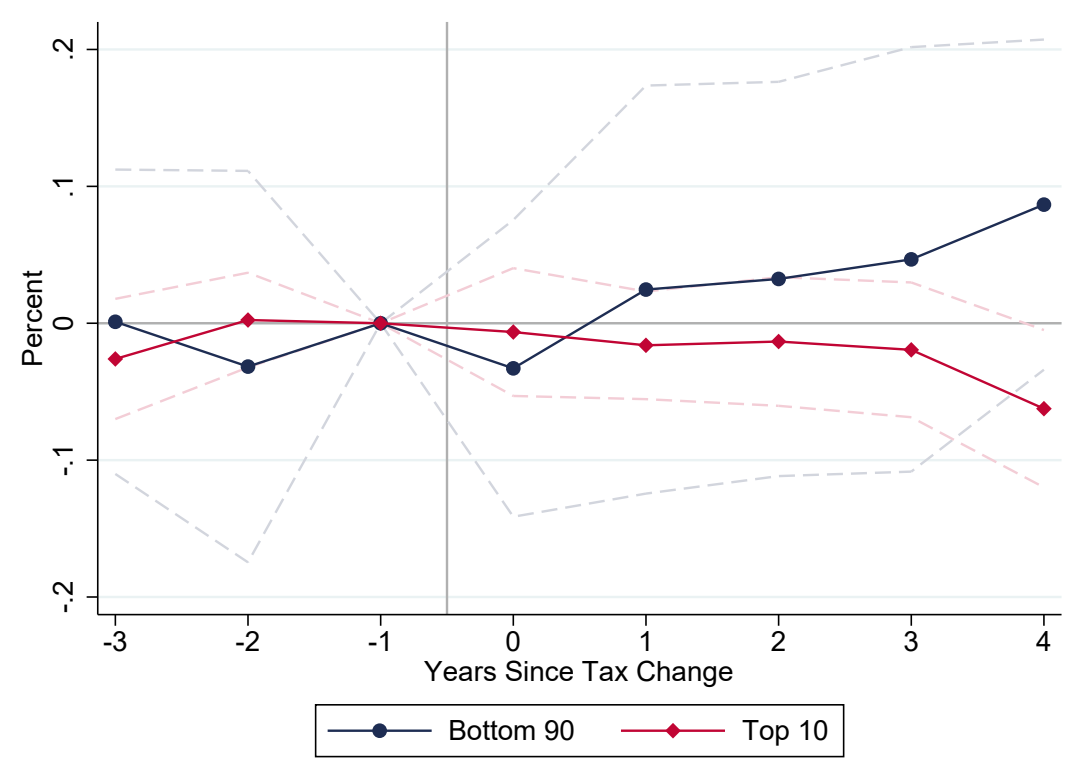

B. Real Wage (Moretti HPI)

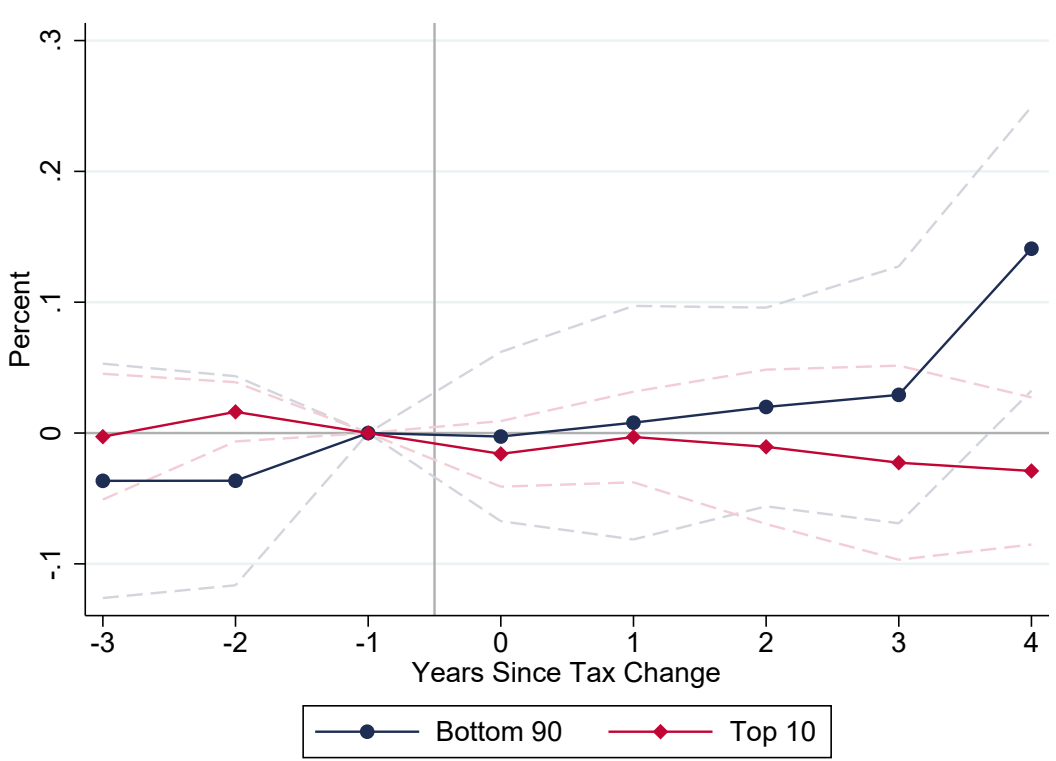

Notes: This figure shows event studies of a $1 \%$ of GDP tax increase on real wages using the BLS price index and Moretti HPI price index $P_{s, t}^{M o r e t t i}$, for those with AGI in the bottom $90 \%$ nationally in blue and for those with AGI in the top $10 \%$ nationally in red. Specifically, the figure plots the estimates from the baseline specification of equation 2 for the impact of tax changes in year $h$ for the bottom $90 \%, \hat{\alpha}_{h}^{B 90}$, and the top 10\%, $\hat{\alpha}_{h}^{T 10}$. The baseline specification includes controls for mechanical changes in AFDC, TANF, SNAP, SSI, and Medicaid spending as a percentage of state GDP, as well as cyclicality-quintile year fixed effects. See section 2 for details. Standard errors are robust and clustered by state; $95 \%$ confidence intervals are shown as dotted lines. The sample period is $1980-2007$. 
Figure A15: Cumulative Growth in Employment-to-Population Ratio by Demographic Split
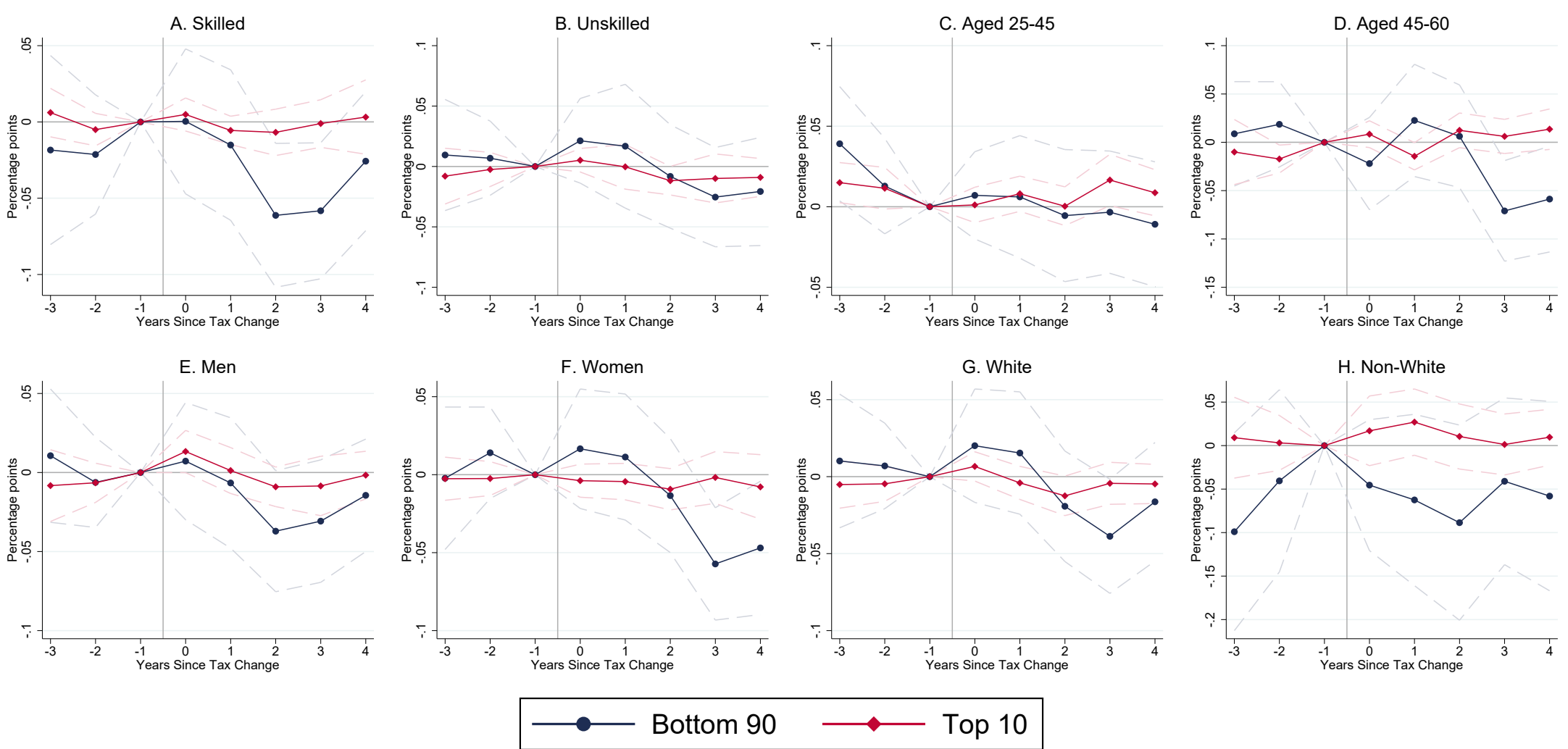

Notes: This figure shows event studies of a $1 \%$ of GDP tax increase on the state employment-to-population ratio by demographic splits for those with AGI in the bottom $90 \%$ nationally in blue and for those with AGI in the top $10 \%$ nationally in red. Specifically, the figure plots the estimates from the baseline specification of equation 2 for the impact of tax changes in year $h$ for the bottom $90 \%, \hat{\alpha}_{h}^{B 90}$, and the top $10 \%, \hat{\alpha}_{h}^{T 10}$. The baseline specification includes controls for mechanical changes in AFDC, TANF, SNAP, SSI, and Medicaid spending as a percentage of state GDP, as well as cyclicality-quintile year fixed effects. See section 2 for details. See section A.2.2 for details on each demographic split. Standard errors are robust and clustered by state; $95 \%$ confidence intervals are shown as dotted lines. The sample period is 1980-2007. 
Figure A16: Cumulative Growth in Employment Rate by Demographic Split
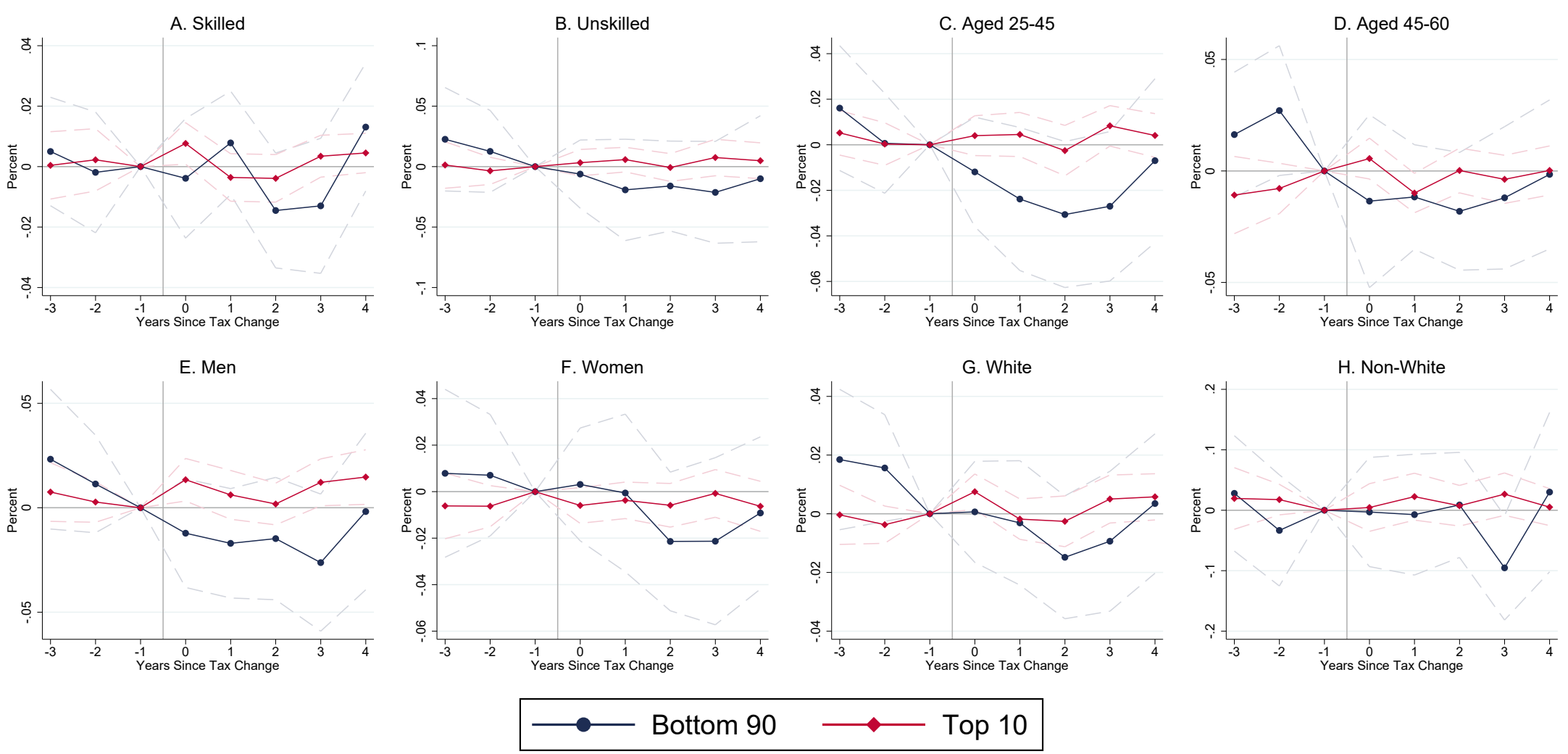

Notes: This figure shows event studies of a $1 \%$ of GDP tax increase on the state employment rate by demographic splits for those with AGI in the bottom $90 \%$ nationally in blue and for those with AGI in the top 10\% nationally in red. Specifically, the figure plots the estimates from the baseline specification of equation 2 for the impact of tax changes in year $h$ for the bottom $90 \%, \hat{\alpha}_{h}^{B 90}$, and the top $10 \%, \hat{\alpha}_{h}^{T 10}$. The baseline specification includes controls for mechanical changes in AFDC, TANF, SNAP, SSI, and Medicaid spending as a percentage of state GDP, as well as cyclicality-quintile year fixed effects. See section 2 for details. See section A.2.2 for details on each demographic split. Standard errors are robust and clustered by state; $95 \%$ confidence intervals are shown as dotted lines. The sample period is 1980-2007. 
Figure A17: Cumulative Growth in Labor Force Participation Rate by Demographic Split
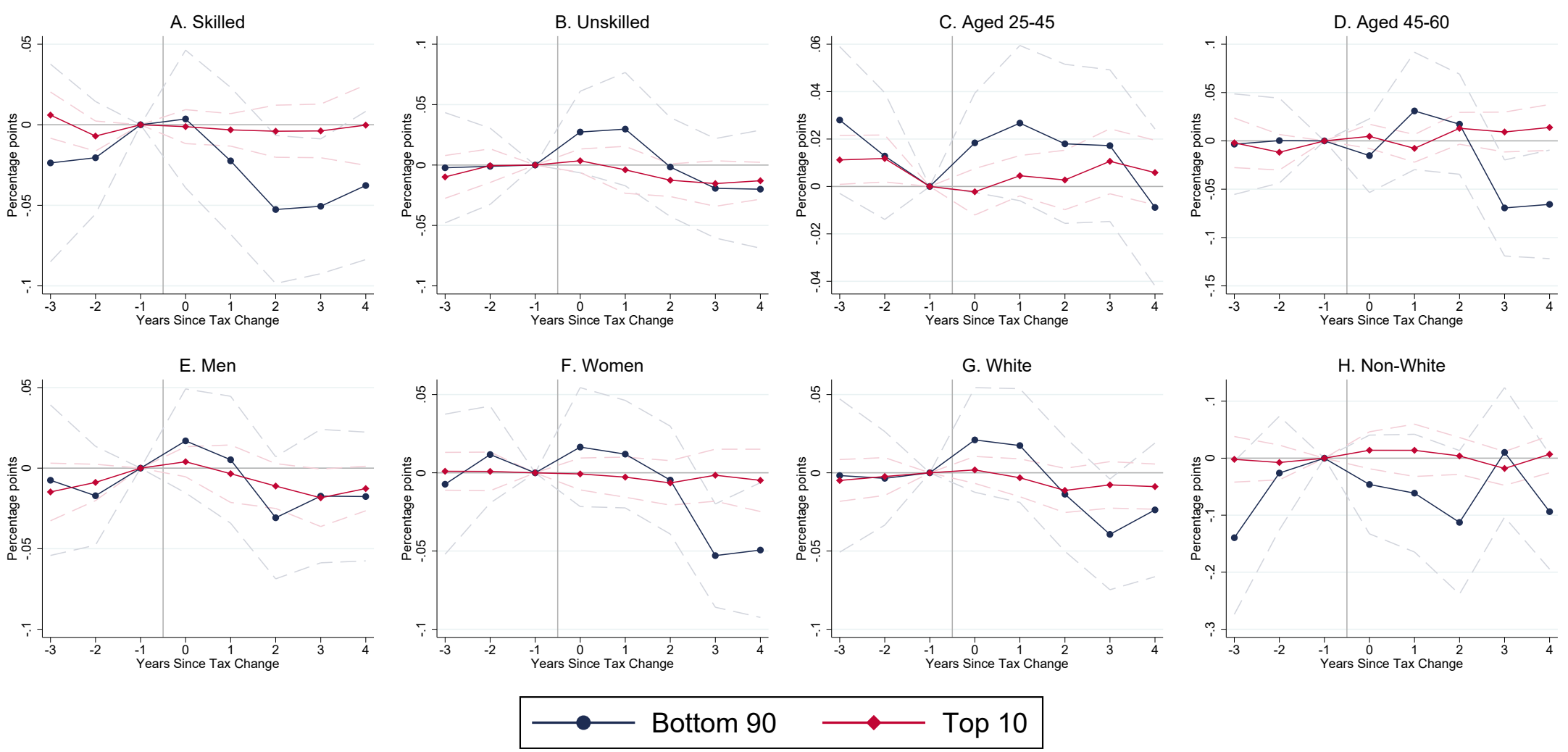

Notes: This figure shows event studies of a $1 \%$ of GDP tax increase on the state labor force participation rate by demographic splits for those with AGI in the bottom $90 \%$ nationally in blue and for those with AGI in the top 10\% nationally in red. Specifically, the figure plots the estimates from the baseline specification of equation 2 for the impact of tax changes in year $h$ for the bottom $90 \%, \hat{\alpha}_{h}^{B 90}$, and the top $10 \%, \hat{\alpha}_{h}^{T 10}$. The baseline specification includes controls for mechanical changes in AFDC, TANF, SNAP, SSI, and Medicaid spending as a percentage of state GDP, as well as cyclicality-quintile year fixed effects. See section 2 for details. See section A.2.2 for details on each demographic split. Standard errors are robust and clustered by state; $95 \%$ confidence intervals are shown as dotted lines. The sample period is 1980-2007. 
Figure A18: Cumulative Growth in Hours by Demographic Split
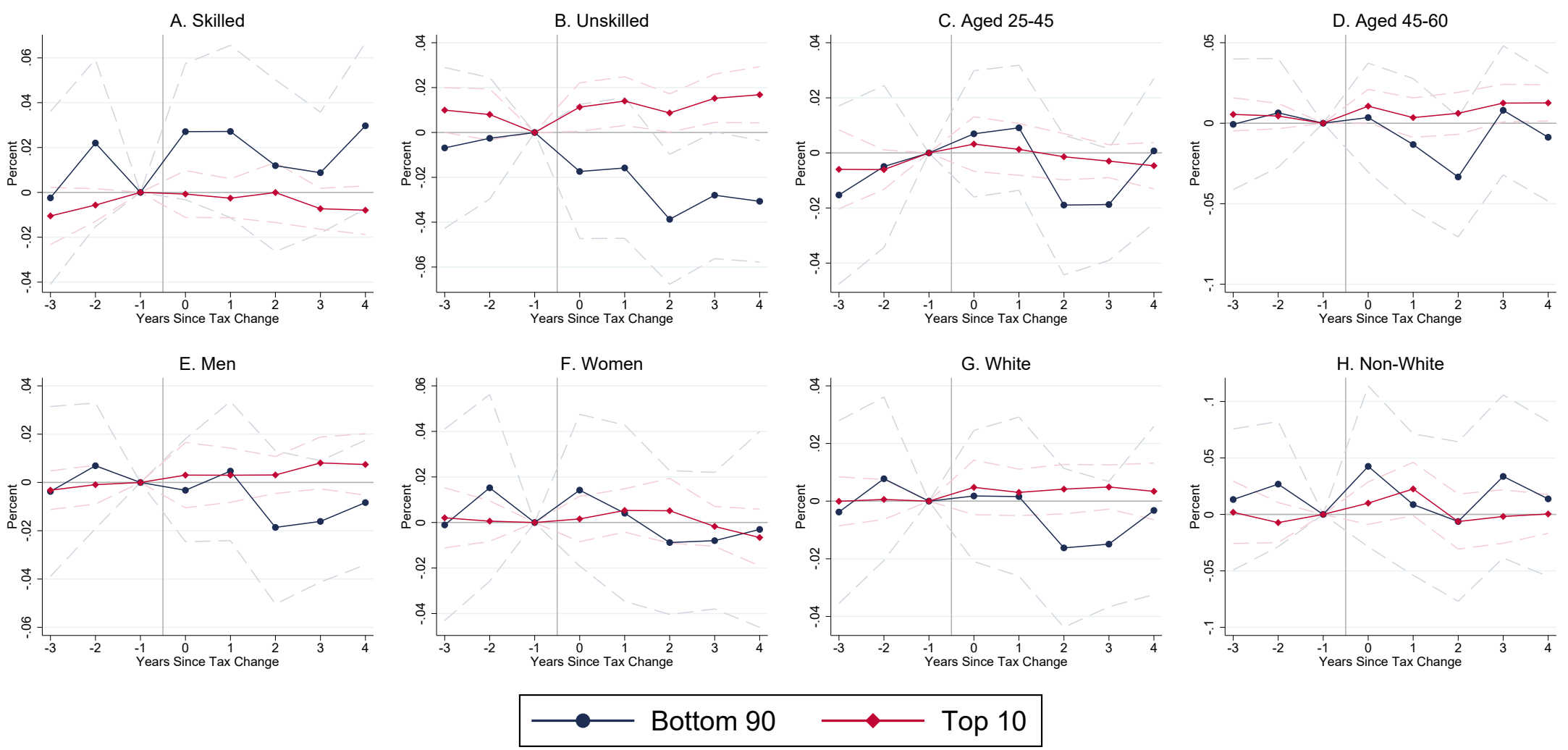

Notes: This figure shows event studies of a $1 \%$ of GDP tax increase on hours worked (if at least 48 weeks were worked in the past year) by demographic splits for those with AGI in the bottom $90 \%$ nationally in blue and for those with AGI in the top 10\% nationally in red. Specifically, the figure plots the estimates from the baseline specification of equation 2 for the impact of tax changes in year $h$ for the bottom $90 \%, \hat{\alpha}_{h}^{B 90}$, and the top $10 \%, \hat{\alpha}_{h}^{T 10}$. The baseline specification includes controls for mechanical changes in AFDC, TANF, SNAP, SSI, and Medicaid spending as a percentage of state GDP, as well as cyclicality-quintile year fixed effects. See section 2 for details. See section A.2.2 for details on each demographic split. Standard errors are robust and clustered by state; $95 \%$ confidence intervals are shown as dotted lines. The sample period is 1980-2007. 
Figure A19: Cumulative Growth in Wage by Demographic Split
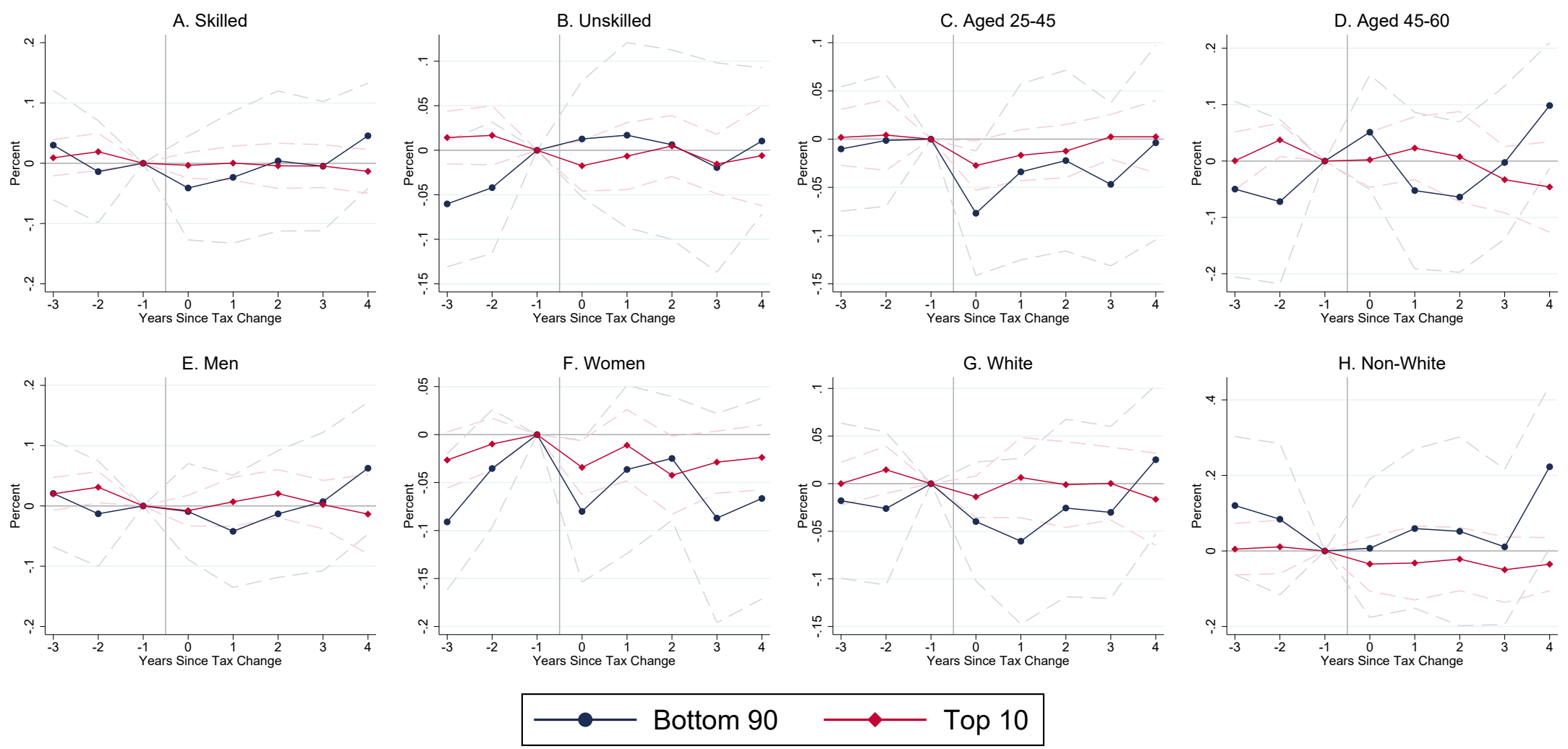

Notes: This figure shows event studies of a $1 \%$ of GDP tax increase on wages by demographic splits for those with AGI in the bottom $90 \%$ nationally in blue and for those with AGI in the top $10 \%$ nationally in red. Specifically, the figure plots the estimates from the baseline specification of equation 2 for the impact of tax changes in year $h$ for the bottom $90 \%, \hat{\alpha}_{h}^{B 90}$, and the top $10 \%, \hat{\alpha}_{h}^{T 10}$. The baseline specification includes controls for mechanical changes in AFDC, TANF, SNAP, SSI, and Medicaid spending as a percentage of state GDP, as well as cyclicality-quintile year fixed effects. See section 2 for details. See section A.2.2 for details on each demographic split. Standard errors are robust and clustered by state; $95 \%$ confidence intervals are shown as dotted lines. The sample period is 1980-2007. 
Figure A20: Cumulative Growth in Real Wage by Demographic Split
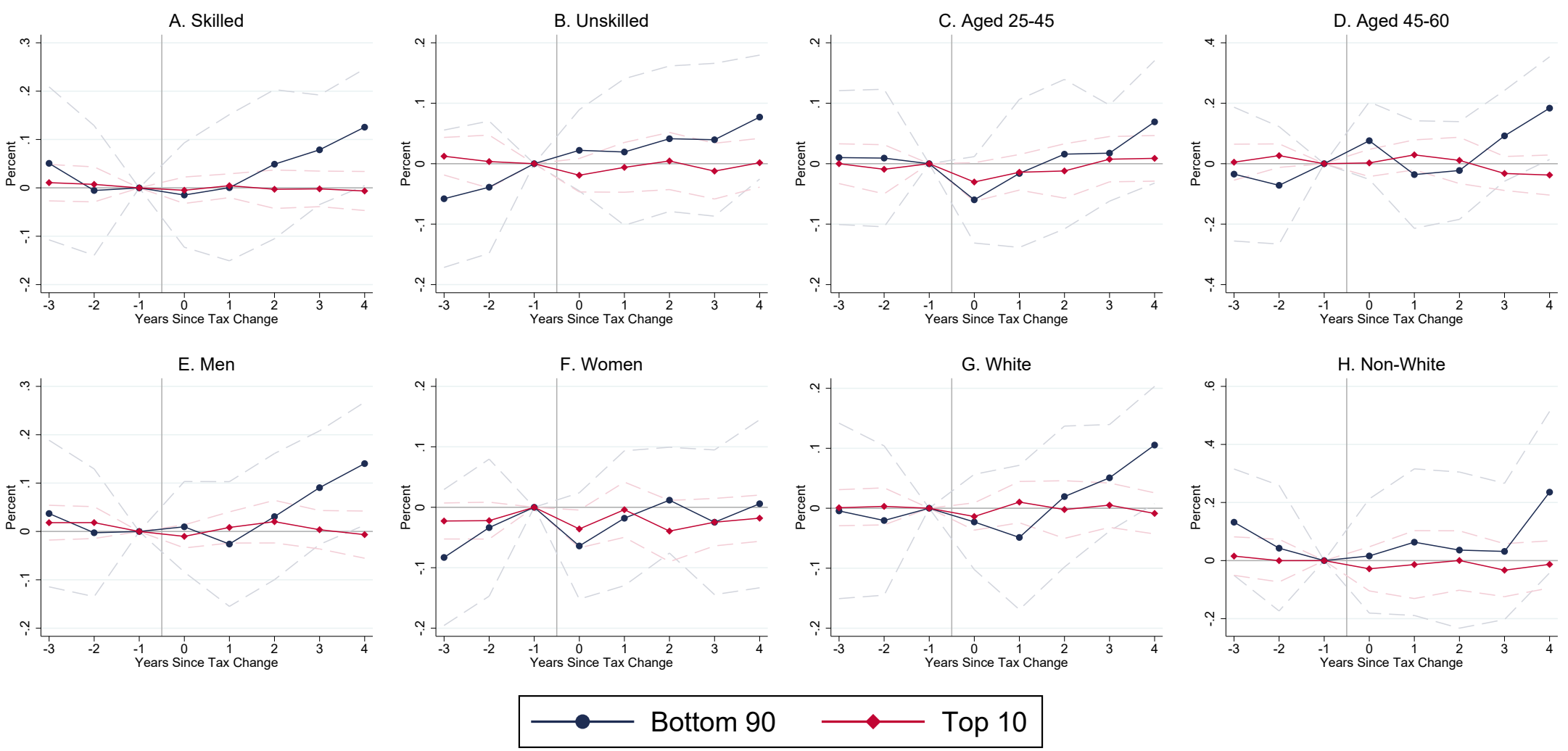

Notes: This figure shows event studies of a $1 \%$ of GDP tax increase on real wages using $P_{s, t}^{A C R A}$ by demographic splits for those with AGI in the bottom $90 \%$ nationally in blue and for those with AGI in the top $10 \%$ nationally in red. Specifically, the figure plots the estimates from the baseline specification of equation 2 for the impact of tax changes in year $h$ for the bottom $90 \%, \hat{\alpha}_{h}^{B 90}$, and the top $10 \%, \hat{\alpha}_{h}^{T 10}$. The baseline specification includes controls for mechanical changes in AFDC, TANF, SNAP, SSI, and Medicaid spending as a percentage of state GDP, as well as cyclicality-quintile year fixed effects. See section 2 for details. See section A.2.2 for details on each demographic split. Standard errors are robust and clustered by state; $95 \%$ confidence intervals are shown as dotted lines. The sample period is 1980-2007. 
Figure A21: Cumulative Growth in Income by Type of Income

A. Total Income

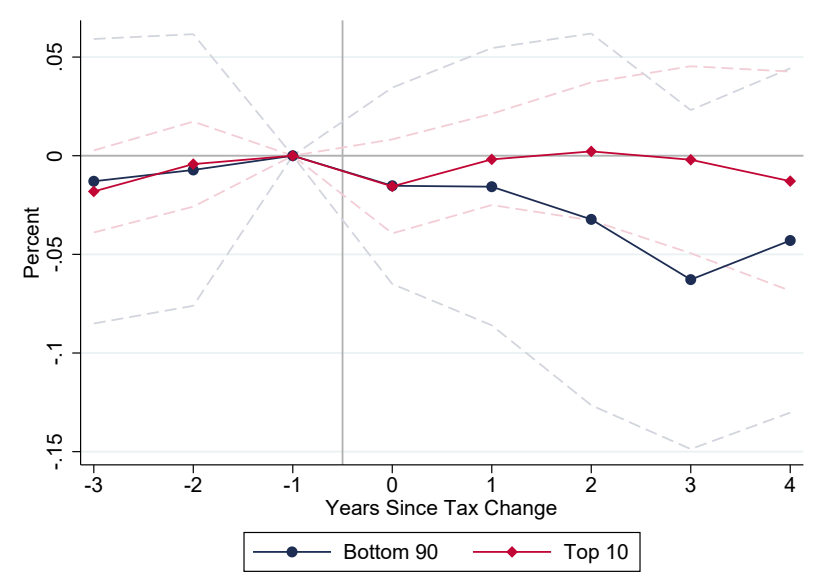

C. Rent Income

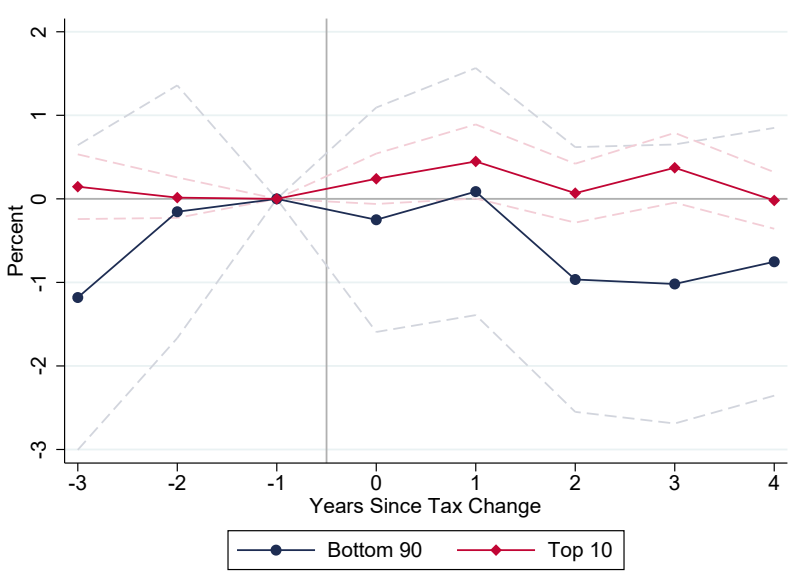

B. Dividends Income

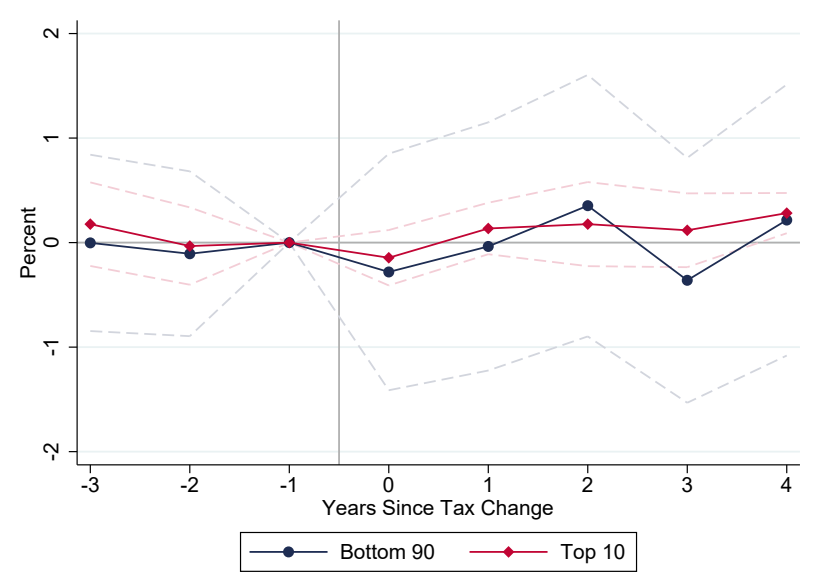

D. Interest Income

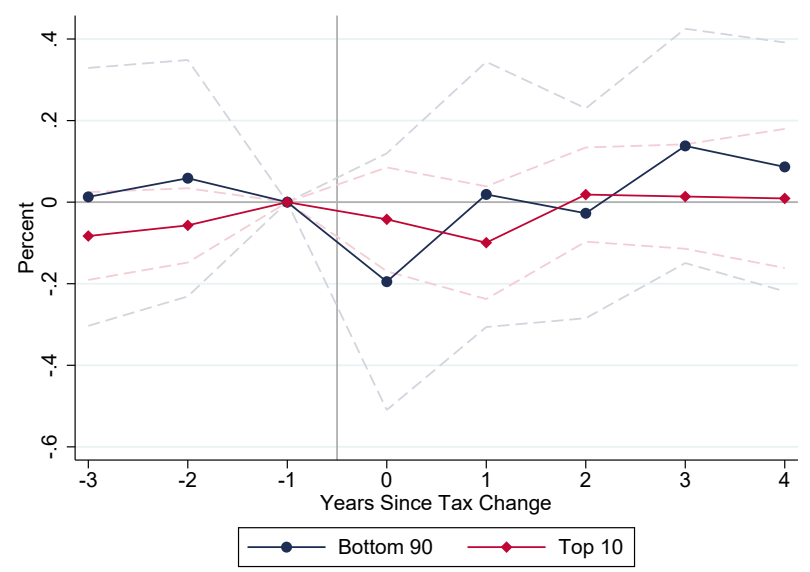

Notes: This figure shows event studies of a $1 \%$ of GDP tax increase on outcomes for those with AGI in the bottom $90 \%$ nationally in blue and for those with AGI in the top $10 \%$ nationally in red. These outcomes are (a) total income, (b) dividends income, (c) rent income, and (d) interest income. Specifically, the figure plots the estimates from the baseline specification of equation 2 for the impact of tax changes in year $h$ for the bottom $90 \%$, $\hat{\alpha}_{h}^{B 90}$, and the top $10 \%$, $\hat{\alpha}_{h}^{T 10}$. The baseline specification includes controls for mechanical changes in AFDC, TANF, SNAP, SSI, and Medicaid spending as a percentage of state GDP, as well as cyclicality-quintile year fixed effects. See section 2 for details. Standard errors are robust and clustered by state; $95 \%$ confidence intervals are shown as dotted lines. The sample period is 1980-2007. 
Figure A22: Cumulative Growth in Payrolls and Earnings
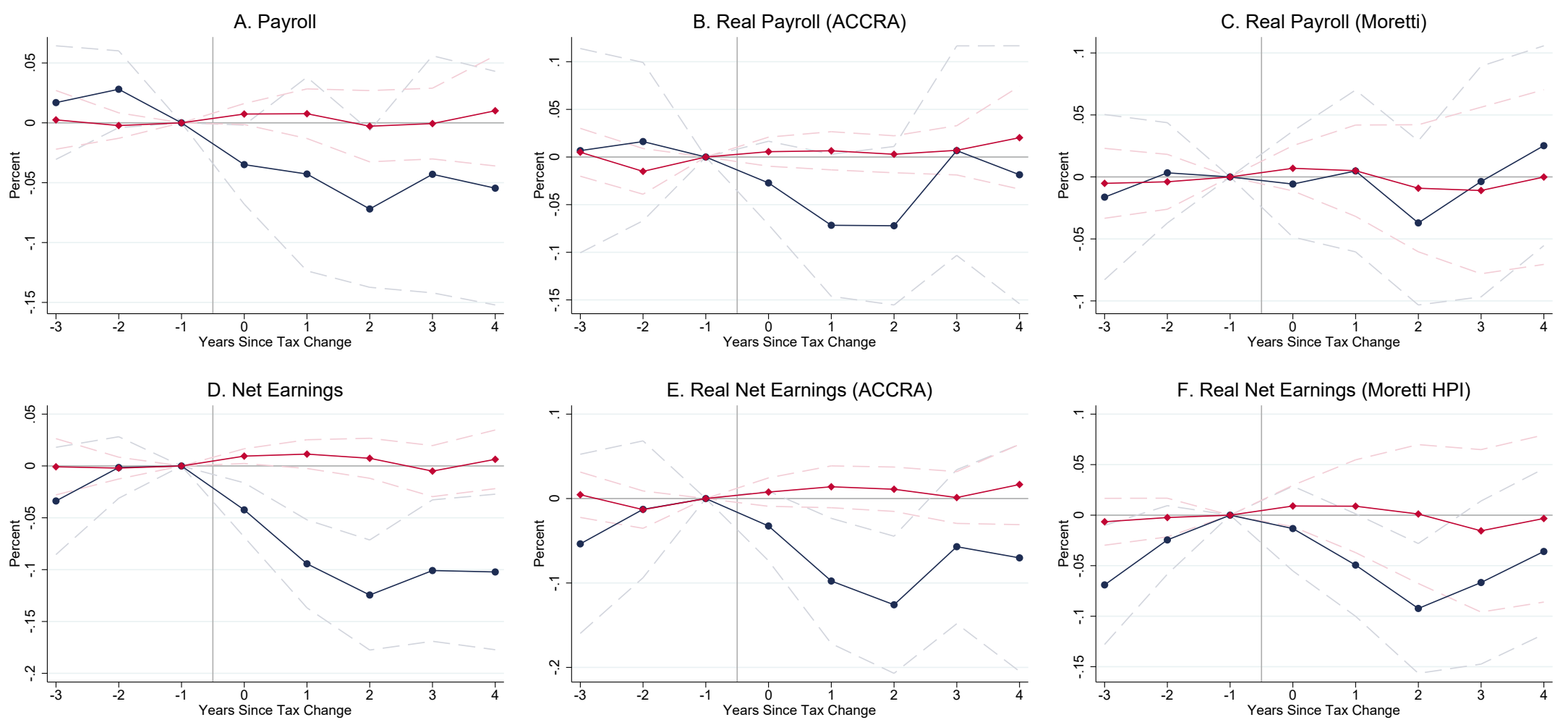

\section{Bottom 90}

Top 10

Notes: This figure shows event studies of a 1\% of GDP tax increase on outcomes for those with AGI in the bottom 90\% nationally in blue and for those with AGI in the top $10 \%$ nationally in red. These outcomes are (a) nominal state payrolls, (b) real state payrolls using $P_{s, t}^{A C C R A}$, (c) real state payrolls using $P_{s, t}^{M o r e t t i},(\mathrm{~d})$ nominal earnings net of contributions for social insurance and dividends, interest, and rental income, (e) real net earnings using $P_{s, t}^{A C C R A}$, and (f) real net earnings using $P_{s, t}^{M o r e t t i}$. Specifically, the figure plots the estimates from the baseline specification of equation 2 for the impact of tax changes in year $h$ for the bottom $90 \%, \hat{\alpha}_{h}^{B 90}$, and the top $10 \%, \hat{\alpha}_{h}^{T 10}$. The baseline specification includes controls for mechanical changes in AFDC, TANF, SNAP, SSI, and Medicaid spending as a percentage of state GDP, as well as cyclicality-quintile year fixed effects. See section 2 for details. Standard errors are robust and clustered by state; $95 \%$ confidence intervals are shown as dotted lines. The sample period is 1980-2007. 
Figure A23: Cumulative Growth in State Wages

\section{A. Nominal Wages}

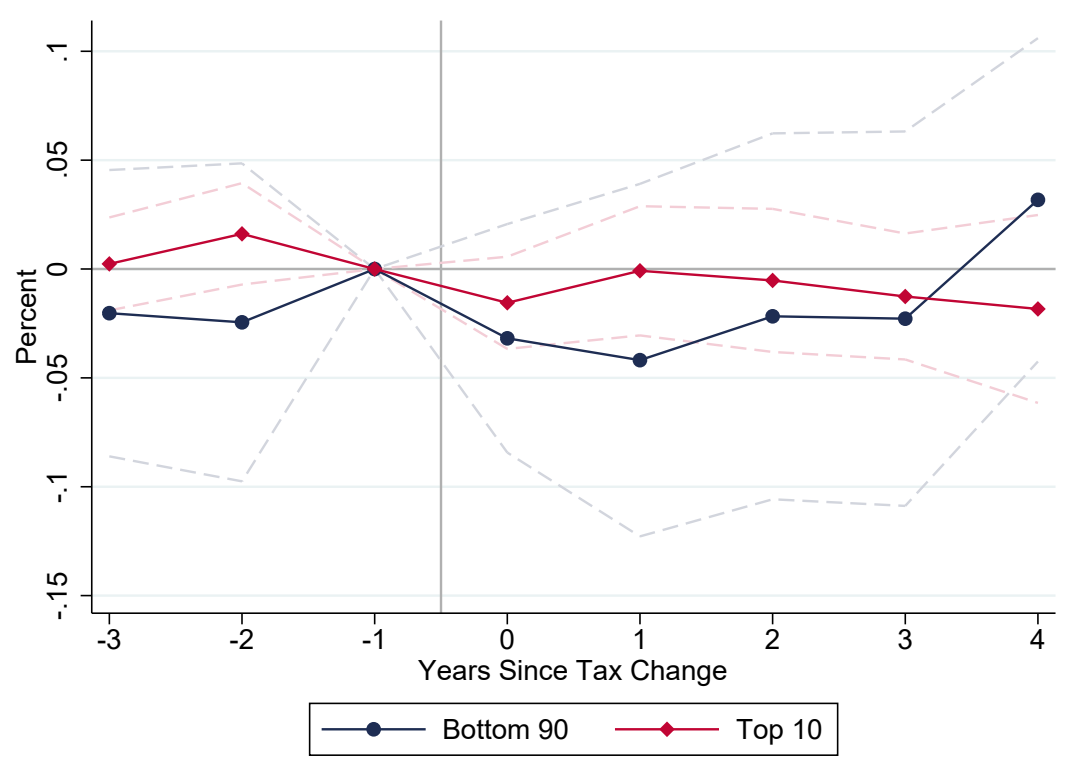

B. Real Wages (ACCRA)

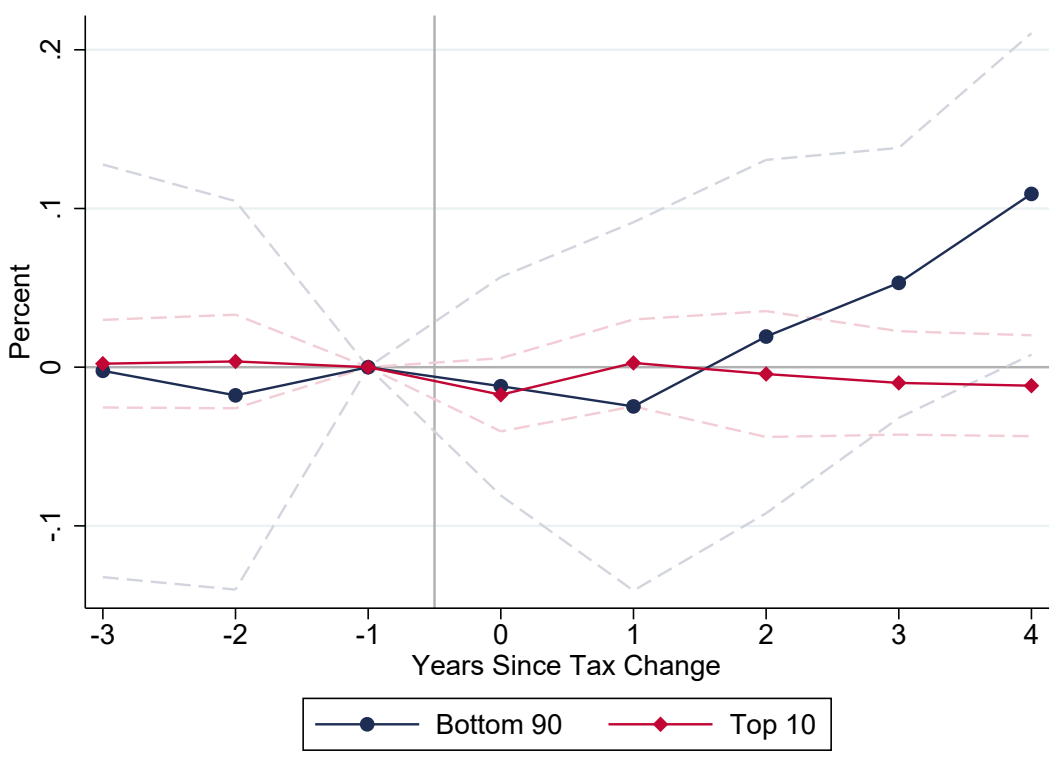

Notes: This figure shows event studies of a $1 \%$ of GDP tax increase on wages and real wages using $P_{s, t}^{A C C R A}$ for those with AGI in the bottom $90 \%$ nationally in blue and for those with AGI in the top $10 \%$ nationally in red. Specifically, the figure plots the estimates from the baseline specification of equation 2 for the impact of tax changes in year $h$ for the bottom $90 \%, \hat{\alpha}_{h}^{B 90}$, and the top $10 \%, \hat{\alpha}_{h}^{T 10}$. The baseline specification includes controls for mechanical changes in AFDC, TANF, SNAP, SSI, and Medicaid spending as a percentage of state GDP, as well as cyclicality-quintile year fixed effects. See section 2 for details. Standard errors are robust and clustered by state; $95 \%$ confidence intervals are shown as dotted lines. Standard errors are robust and clustered by state; 95\% confidence intervals are shown as dotted lines. The sample period is 1980-2007. 
Figure A24: Cumulative Growth in Part-time Employment Rate

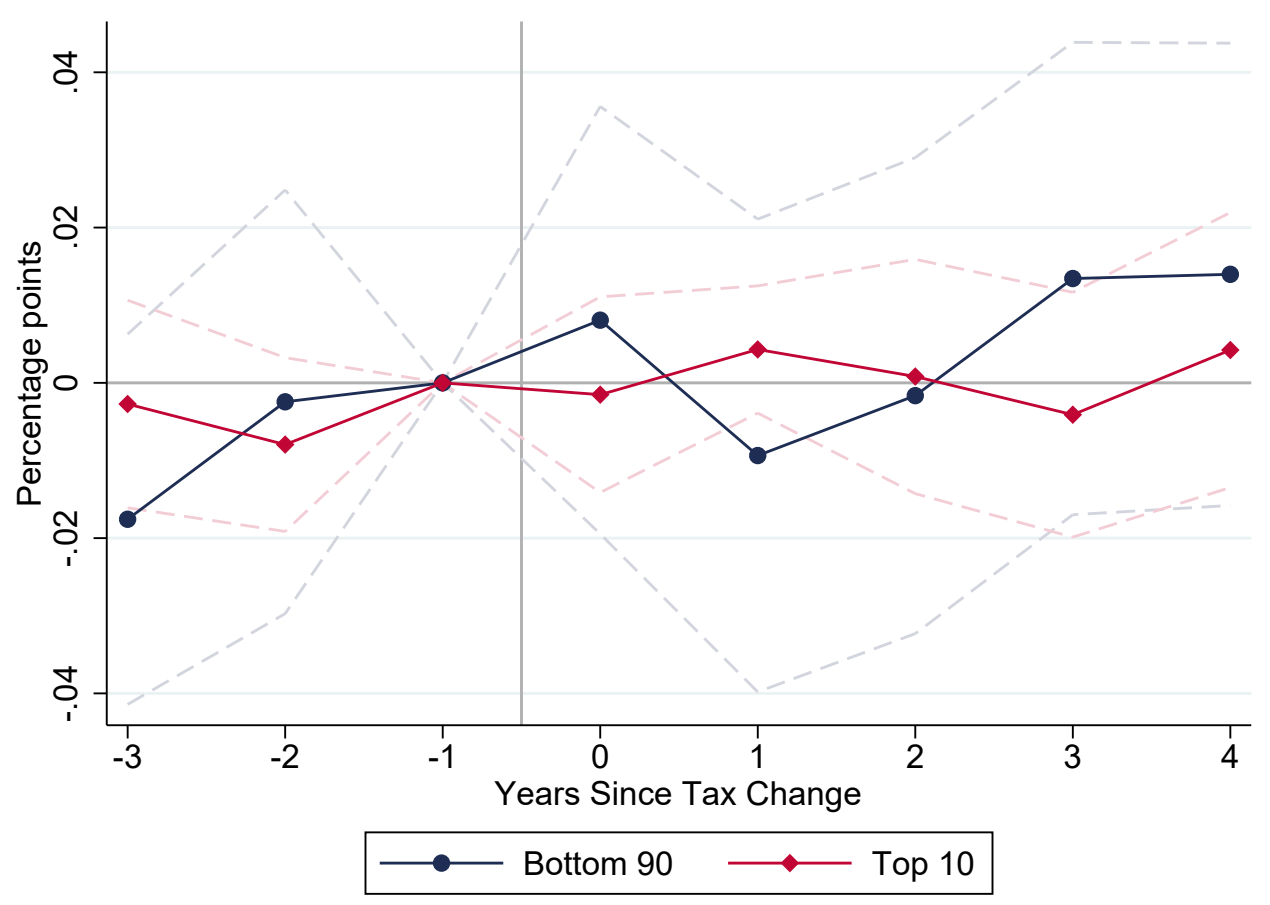

Notes: This figure shows event studies of a $1 \%$ of GDP tax increase on the part-time employment rate for those with AGI in the bottom $90 \%$ nationally in blue and for those with AGI in the top $10 \%$ nationally in red. Specifically, the figure plots the estimates from the baseline specification of equation 2 for the impact of tax changes in year $h$ for the bottom $90 \%, \hat{\alpha}_{h}^{B 90}$, and the top $10 \%, \hat{\alpha}_{h}^{T 10}$. The baseline specification includes controls for mechanical changes in AFDC, TANF, SNAP, SSI, and Medicaid spending as a percentage of state GDP, as well as cyclicality-quintile year fixed effects. See section 2 for details. Standard errors are robust and clustered by state; $95 \%$ confidence intervals are shown as dotted lines. The sample period is 1980-2007. 
Figure A25: Cumulative Growth in State Emp-to-Pop Ratio and Employment: Includes Non-Personal Income Taxes in Top Decile

\section{A. Employment/Population}

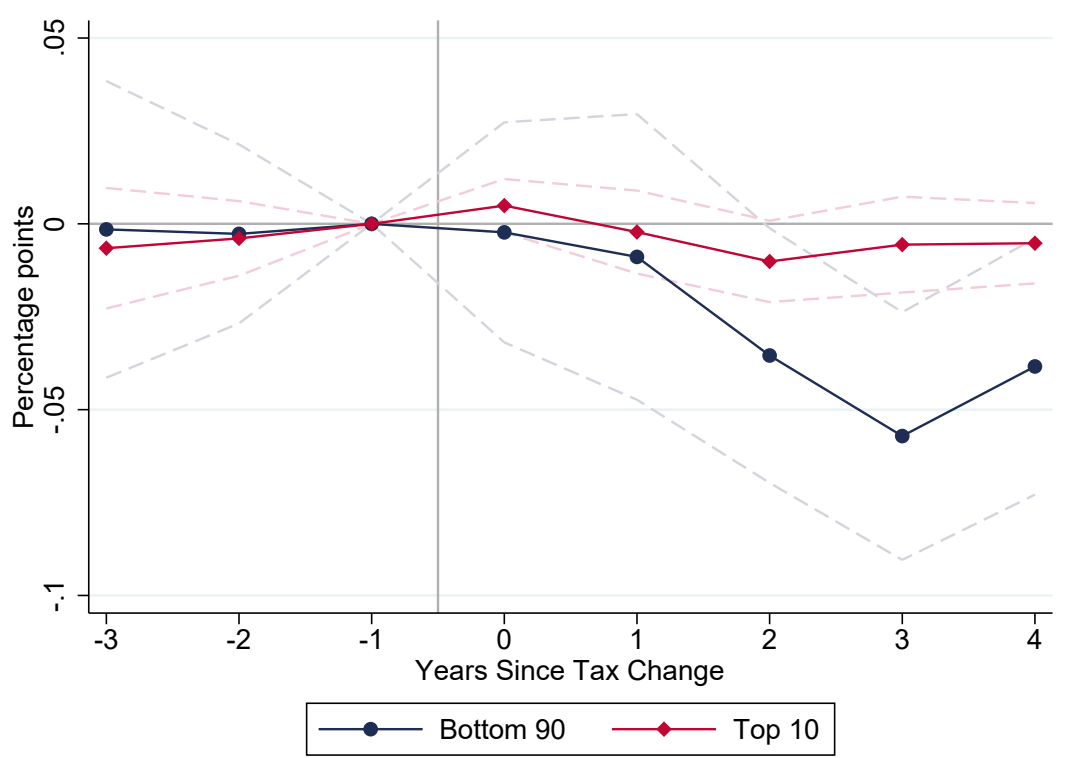

B. Employment

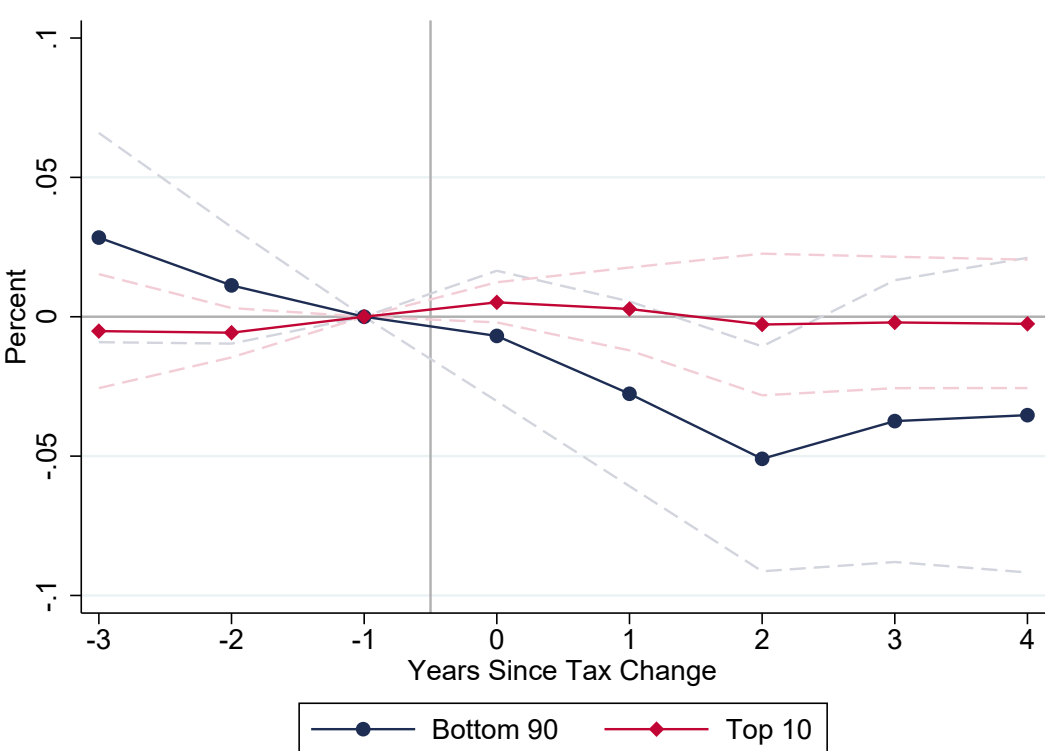

Notes: This figure shows event studies of a 1\% of GDP tax increase on the state employment-to-population ratio and employment for those with AGI in the bottom $90 \%$ nationally in blue and for those with AGI in the top $10 \%$ nationally in red. Specifically, the figure plots the estimates from the specification of equation 2 for the impact of tax changes in year $h$ for the bottom $90 \%, \hat{\alpha}_{h}^{B 90}$, and the top $10 \%, \hat{\alpha}_{h}^{T 10}$. However, unlike the baseline specification definition for tax changes for the top 10\%, I also allocate the non-personal income tax changes to top earners in the same proportion as the top $10 \%$ shares are allocated. This is done in an attempt to resolve potential issues with exclusions of non-personal income taxes (corporate taxes, etc.) biasing estimates for the Top 10\% group. The baseline specification includes controls for mechanical changes in AFDC, TANF, SNAP, SSI, and Medicaid spending as a percentage of state GDP, as well as cyclicality-quintile year fixed effects. See section 2 for details. Standard errors are robust and clustered by state; $95 \%$ confidence intervals are shown as dotted lines. The sample period is 1980-2007. 
Figure A26: Cumulative Growth in Emp-to-Pop Ratio and Employment: Bottom 80\% and Top 20\%

A. Employment-to-Population Ratio

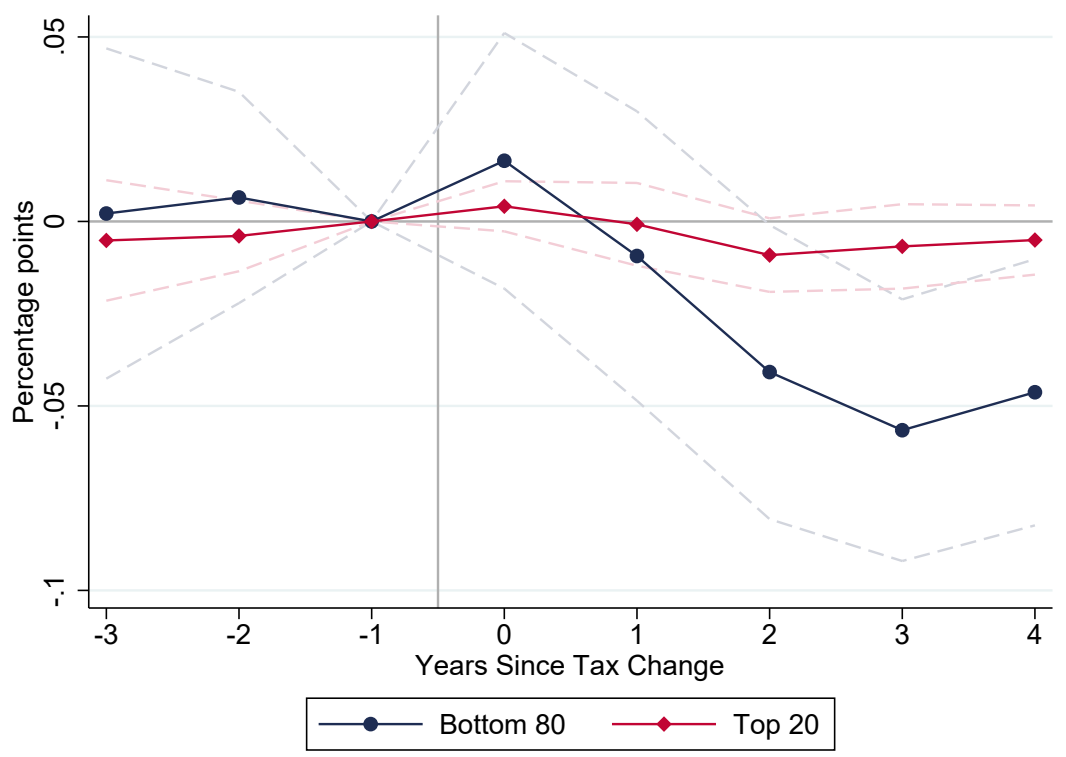

B. Employment

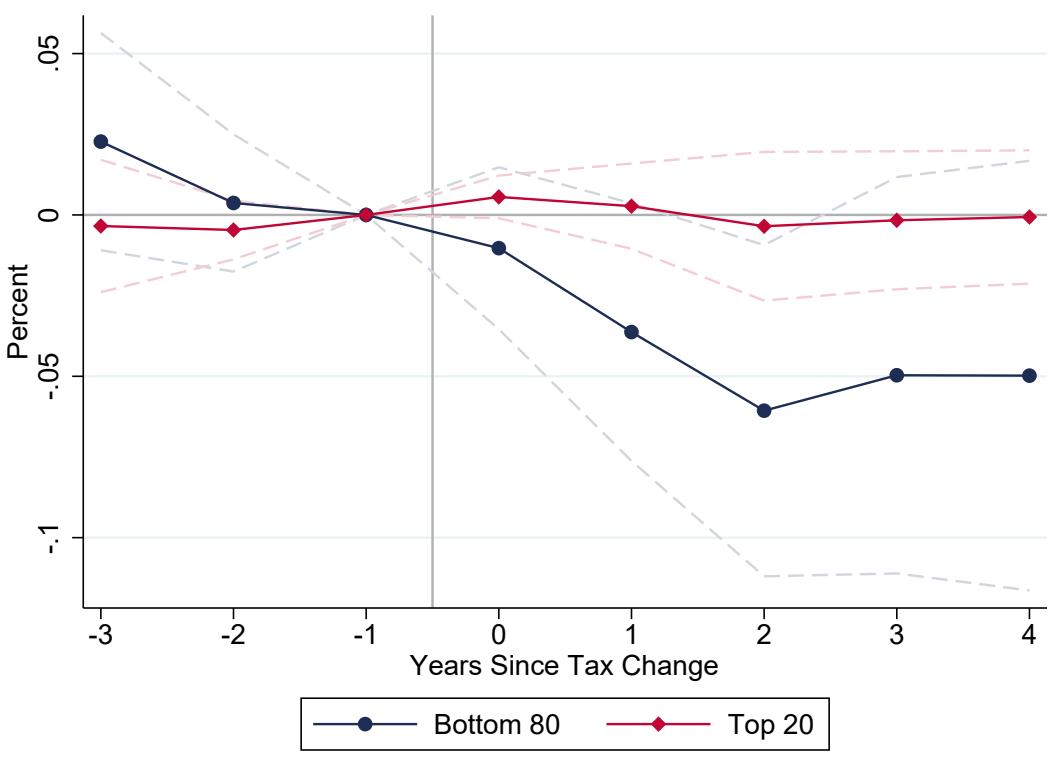

Notes: This figure shows event studies of a 1\% of GDP tax increase on the state employment-to-population ratio and employment for those with AGI in the bottom $80 \%$ nationally in blue and for those with AGI in the top $20 \%$ nationally in red. Specifically, the figure plots the estimates from equation 2 for the impact of tax changes in year $h$ for the bottom $80 \%, \hat{\alpha}_{h}^{B 80}$, and the top $20 \%, \hat{\alpha}_{h}^{T 20}$. The baseline specification includes controls for mechanical changes in AFDC, TANF, SNAP, SSI, and Medicaid spending as a percentage of state GDP, as well as cyclicality-quintile year fixed effects. See section 2 for details. Standard errors are robust and clustered by state; $95 \%$ confidence intervals are shown as dotted lines. The sample period is 1980-2007. 
Table A3: Summary Statistics

\begin{tabular}{|c|c|c|c|c|c|}
\hline \multicolumn{6}{|c|}{ Panel A: State Summary Statistics } \\
\hline Variable & Mean & Std. Dev. & Min. & Max & $\mathbf{N}$ \\
\hline Year & & & 1980 & 2007 & 1400 \\
\hline Log Employment & 15.151 & 0.879 & 12.04 & 16.64 & 1400 \\
\hline Log State GDP & 26.585 & 0.976 & 23.36 & 28.43 & 1400 \\
\hline Employment Rate & 93.520 & 2.111 & 81.23 & 97.94 & 1400 \\
\hline Emp/Pop & 60.145 & 4.175 & 39.72 & 73.45 & 1400 \\
\hline LFP Rate & 64.277 & 3.676 & 46.27 & 76.74 & 1400 \\
\hline Part-Time Emp Rate & 18.747 & 3.655 & 10.06 & 37.94 & 1400 \\
\hline Log Payroll & 25.763 & 0.989 & 22.61 & 27.53 & 1400 \\
\hline Log Hours & 7.657 & 0.017 & 7.58 & 7.72 & 1400 \\
\hline Log Wages & 3.071 & 0.137 & 2.49 & 3.46 & 1400 \\
\hline Log Comp-Constant Wages & 2.996 & 0.122 & 2.45 & 3.36 & 1400 \\
\hline Employment Growth & 1.388 & 1.632 & -6.77 & 10.35 & 1350 \\
\hline GDP Growth & 2.758 & 2.933 & -32.89 & 25.76 & 1350 \\
\hline Real GDP Growth (ACCRA) & 2.655 & 3.692 & -59.01 & 27.77 & 1246 \\
\hline Real GDP Growth (Moretti) & 2.670 & 3.273 & -29.48 & 22.26 & 1350 \\
\hline$T_{s, t}^{B 90}$ & -0.075 & 0.186 & -1.08 & 0.46 & 1400 \\
\hline$T_{s, t}^{T 10}$ & -0.013 & 0.171 & -1.27 & 1.57 & 1400 \\
\hline \multicolumn{6}{|c|}{ Panel B: National Summary Statistics } \\
\hline Variable & Mean & Std. Dev. & Min. & Max & $\mathbf{N}$ \\
\hline Year & & & 1950 & 2007 & 58 \\
\hline GDP Growth & 3.366 & 2.144 & -1.93 & 7.75 & 57 \\
\hline Investment Growth & 3.855 & 8.326 & -17.67 & 24.13 & 57 \\
\hline Residential Investment Growth & 2.141 & 11.791 & -23.47 & 35.05 & 57 \\
\hline Consumption Growth & 3.507 & 1.653 & -0.83 & 7.12 & 57 \\
\hline Durable Consumption Growth & 4.956 & 6.192 & -8.68 & 19.33 & 57 \\
\hline Non-Durable Consumption Growth & 2.653 & 1.422 & -2.46 & 5.41 & 57 \\
\hline$T_{t}^{B 90}$ & -0.038 & 0.139 & -0.45 & 0.28 & 58 \\
\hline$T_{t}^{T 10}$ & -0.023 & 0.135 & -0.49 & 0.31 & 58 \\
\hline
\end{tabular}


Table A4: 2-Year Change - Demographic Robustness

\begin{tabular}{|c|c|c|c|c|c|}
\hline \multicolumn{6}{|c|}{ Panel A: Skill } \\
\hline Skilled & LFP Rate & Emp Rate & Hours & Wage & Real Wage \\
\hline Bottom 90 & $\begin{array}{l}-2.21^{*} \\
(1.20)\end{array}$ & $\begin{array}{l}-0.56 \\
(0.45)\end{array}$ & $\begin{array}{c}0.24 \\
(0.93)\end{array}$ & $\begin{array}{l}-1.05 \\
(3.51)\end{array}$ & $\begin{array}{c}1.91 \\
(4.53)\end{array}$ \\
\hline Top 10 & $\begin{array}{c}0.03 \\
(0.40)\end{array}$ & $\begin{array}{l}-0.33^{*} \\
(0.19)\end{array}$ & $\begin{array}{c}0.08 \\
(0.32)\end{array}$ & $\begin{array}{l}-0.87 \\
(1.34)\end{array}$ & $\begin{array}{l}-0.43 \\
(0.96)\end{array}$ \\
\hline$\underline{\text { Unskilled }}$ & & & & & \\
\hline$\overline{\text { Bottom } 90}$ & $\begin{array}{c}0.74 \\
(1.21)\end{array}$ & $\begin{array}{l}-2.12^{*} \\
(1.20)\end{array}$ & $\begin{array}{c}-2.11^{* * *} \\
(0.79)\end{array}$ & $\begin{array}{c}0.69 \\
(2.59)\end{array}$ & $\begin{array}{c}2.31 \\
(3.01)\end{array}$ \\
\hline Top 10 & $\begin{array}{l}-0.53^{*} \\
(0.32)\end{array}$ & $\begin{array}{c}0.29 \\
(0.28)\end{array}$ & $\begin{array}{c}0.48^{* * *} \\
(0.17)\end{array}$ & $\begin{array}{l}-0.76 \\
(0.96)\end{array}$ & $\begin{array}{l}-0.36 \\
(0.99)\end{array}$ \\
\hline \multicolumn{6}{|c|}{ Panel B: Age } \\
\hline Aged 25-45 & LFP Rate & Emp Rate & Hours & Wage & Real Wage \\
\hline$\overline{\text { Bottom } 90}$ & $\begin{array}{c}0.53 \\
(0.98)\end{array}$ & $\begin{array}{c}-2.52^{* *} \\
(0.94)\end{array}$ & $\begin{array}{l}-0.49 \\
(0.63)\end{array}$ & $\begin{array}{l}-2.85 \\
(2.84)\end{array}$ & $\begin{array}{l}-0.33 \\
(3.66)\end{array}$ \\
\hline Top 10 & $\begin{array}{l}-0.17 \\
(0.35)\end{array}$ & $\begin{array}{c}0.08 \\
(0.28)\end{array}$ & $\begin{array}{c}0.20 \\
(0.23)\end{array}$ & $\begin{array}{l}-1.33 \\
(1.06)\end{array}$ & $\begin{array}{l}-0.91 \\
(0.97)\end{array}$ \\
\hline Aged 45-60 & & & & & \\
\hline$\overline{\text { Bottom } 90}$ & $\begin{array}{c}0.65 \\
(1.48)\end{array}$ & $\begin{array}{c}-2.17^{* * *} \\
(0.69)\end{array}$ & $\begin{array}{c}-2.31^{* *} \\
(0.87)\end{array}$ & $\begin{array}{l}-1.92 \\
(3.44)\end{array}$ & $\begin{array}{c}0.09 \\
(4.69)\end{array}$ \\
\hline Top 10 & $\begin{array}{c}0.58 \\
(0.46)\end{array}$ & $\begin{array}{l}-0.03 \\
(0.22)\end{array}$ & $\begin{array}{c}0.17 \\
(0.33)\end{array}$ & $\begin{array}{l}-0.21 \\
(2.01)\end{array}$ & $\begin{array}{c}0.46 \\
(1.62)\end{array}$ \\
\hline \multicolumn{6}{|c|}{ Panel C: Sex } \\
\hline Men & LFP Rate & Emp Rate & Hours & Wage & Real Wage \\
\hline 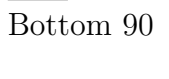 & $\begin{array}{l}-0.52 \\
(0.98)\end{array}$ & $\begin{array}{c}-1.95^{* *} \\
(0.83)\end{array}$ & $\begin{array}{l}-0.91 \\
(0.78)\end{array}$ & $\begin{array}{l}\overline{-2.38} \\
(2.92)\end{array}$ & $\begin{array}{c}0.26 \\
(3.95)\end{array}$ \\
\hline Top 10 & $\begin{array}{l}-0.21 \\
(0.34)\end{array}$ & $\begin{array}{c}0.20 \\
(0.27)\end{array}$ & $\begin{array}{c}0.26 \\
(0.22)\end{array}$ & $\begin{array}{l}-0.23 \\
(1.45)\end{array}$ & $\begin{array}{c}0.15 \\
(1.09)\end{array}$ \\
\hline Women & & & & & \\
\hline$\overline{\text { Bottom } 90}$ & $\begin{array}{l}-0.50 \\
(0.94)\end{array}$ & $\begin{array}{l}-1.44 \\
(0.97)\end{array}$ & $\begin{array}{l}-1.15 \\
(0.92)\end{array}$ & $\begin{array}{l}-2.13 \\
(2.27)\end{array}$ & $\begin{array}{l}-0.00 \\
(2.80)\end{array}$ \\
\hline Top 10 & $\begin{array}{l}-0.30 \\
(0.39)\end{array}$ & $\begin{array}{l}-0.15 \\
(0.23)\end{array}$ & $\begin{array}{c}0.29 \\
(0.32)\end{array}$ & $\begin{array}{l}-1.71 \\
(1.39)\end{array}$ & $\begin{array}{l}-1.14 \\
(1.49)\end{array}$ \\
\hline \multicolumn{6}{|c|}{ Panel D: Race } \\
\hline White & LFP Rate & Emp Rate & Hours & Wage & Real Wage \\
\hline Bottom 90 & $\begin{array}{c}0.03 \\
(0.89)\end{array}$ & $\begin{array}{c}-1.68 * * \\
(0.75)\end{array}$ & $\begin{array}{l}-1.00 \\
(0.64)\end{array}$ & $\begin{array}{l}-3.10 \\
(2.57)\end{array}$ & $\begin{array}{l}-0.73 \\
(3.41)\end{array}$ \\
\hline Top 10 & $\begin{array}{l}-0.38 \\
(0.40)\end{array}$ & $\begin{array}{l}-0.02 \\
(0.22)\end{array}$ & $\begin{array}{c}0.20 \\
(0.23)\end{array}$ & $\begin{array}{l}-0.45 \\
(1.62)\end{array}$ & $\begin{array}{l}-0.11 \\
(1.28)\end{array}$ \\
\hline Non-White & & & & & \\
\hline$\overline{\text { Bottom } 90}$ & $\begin{array}{c}-6.25^{* *} \\
(3.08)\end{array}$ & $\begin{array}{c}0.01 \\
(2.20)\end{array}$ & $\begin{array}{l}-2.54 \\
(1.78)\end{array}$ & $\begin{array}{c}5.54 \\
(5.82)\end{array}$ & $\begin{array}{c}7.52 \\
(7.10)\end{array}$ \\
\hline Top 10 & $\begin{array}{c}0.89 \\
(1.05)\end{array}$ & $\begin{array}{c}0.40 \\
(0.88)\end{array}$ & $\begin{array}{c}0.93 \\
(0.69)\end{array}$ & $\begin{array}{l}-3.16 \\
(2.43)\end{array}$ & $\begin{array}{l}-1.51 \\
(3.01)\end{array}$ \\
\hline
\end{tabular}

Notes: This table presents state-level estimates of two-year tax changes for different demographic groups. Each specification is the same as column 1 in Table 1. The subsample (demographic group) of outcomes drawn from the CPS varies, as specified in the first column. In the cases of the labor force participation rate and employment rate, the outcomes are the simple difference, i.e., $Y_{s, t}-Y_{s, t-2}$, rather than the ratio described in equation 3. Hours are restricted to those working at least 48 weeks in the past year. See section A.2.2 for details on each demographic split. In each specification, I absorb state-specific effects and cluster standard errors by state $(* * *$ $\left.\mathrm{p}<0.01,{ }^{* *} \mathrm{p}<0.05,{ }^{*} \mathrm{p}<0.1\right)$. The sample period is $1980-2007$. 
Table A5: 2-Year Change - Policy Robustness (Additional)

\begin{tabular}{|c|c|c|c|c|c|c|}
\hline & $(1)$ & $(2)$ & $(3)$ & $(4)$ & $(5)$ & $(6)$ \\
\hline \multicolumn{7}{|l|}{ Employment } \\
\hline Bottom 90 & $\begin{array}{c}-4.74^{* *} \\
(1.79)\end{array}$ & $\begin{array}{c}-3.21^{* *} \\
(1.54)\end{array}$ & $\begin{array}{c}-3.61^{* *} \\
(1.50)\end{array}$ & $\begin{array}{c}-4.74^{* *} \\
(1.79)\end{array}$ & $\begin{array}{c}-3.15^{* *} \\
(1.49)\end{array}$ & $\begin{array}{c}-3.43^{* *} \\
(1.55)\end{array}$ \\
\hline Top 10 & $\begin{array}{c}0.16 \\
(0.93)\end{array}$ & $\begin{array}{l}-0.10 \\
(0.71)\end{array}$ & $\begin{array}{c}0.29 \\
(0.83)\end{array}$ & $\begin{array}{c}0.16 \\
(0.93)\end{array}$ & $\begin{array}{c}0.22 \\
(0.88)\end{array}$ & $\begin{array}{c}0.21 \\
(0.89)\end{array}$ \\
\hline \multicolumn{7}{|l|}{ State GDP } \\
\hline$\overline{\text { Bottom } 90}$ & $\begin{array}{c}-12.12^{\text {*** }} \\
(2.19)\end{array}$ & $\begin{array}{c}-11.65^{* * *} \\
(2.22)\end{array}$ & $\begin{array}{c}-12.28^{* * *} \\
(2.22)\end{array}$ & $\begin{array}{c}-12.11^{* * *} \\
(2.19)\end{array}$ & $\begin{array}{c}-11.08^{* * *} \\
(1.99)\end{array}$ & $\begin{array}{c}-11.98^{* * *} \\
(2.21)\end{array}$ \\
\hline Top 10 & $\begin{array}{c}0.40 \\
(1.03)\end{array}$ & $\begin{array}{c}0.39 \\
(0.91)\end{array}$ & $\begin{array}{c}0.87 \\
(0.89)\end{array}$ & $\begin{array}{c}0.40 \\
(1.03)\end{array}$ & $\begin{array}{c}0.75 \\
(0.89)\end{array}$ & $\begin{array}{c}0.75 \\
(0.97)\end{array}$ \\
\hline \multicolumn{7}{|l|}{ Employment Rate } \\
\hline Bottom 90 & $\begin{array}{l}-1.98^{*} \\
(0.99)\end{array}$ & $\begin{array}{c}-1.79^{* *} \\
(0.82)\end{array}$ & $\begin{array}{c}-1.76^{* *} \\
(0.78)\end{array}$ & $\begin{array}{l}-1.98^{*} \\
(0.99)\end{array}$ & $\begin{array}{c}-1.62^{* *} \\
(0.77)\end{array}$ & $\begin{array}{c}-1.72^{* *} \\
(0.79)\end{array}$ \\
\hline Top 10 & $\begin{array}{c}0.05 \\
(0.22)\end{array}$ & $\begin{array}{c}0.06 \\
(0.22)\end{array}$ & $\begin{array}{c}0.05 \\
(0.21)\end{array}$ & $\begin{array}{c}0.05 \\
(0.22)\end{array}$ & $\begin{array}{c}0.05 \\
(0.21)\end{array}$ & $\begin{array}{c}0.07 \\
(0.22)\end{array}$ \\
\hline \multicolumn{7}{|l|}{ Emp/Pop } \\
\hline$\overline{\text { Bottom } 90}$ & $\begin{array}{l}-1.76 \\
(1.19)\end{array}$ & $\begin{array}{l}-1.66 \\
(1.00)\end{array}$ & $\begin{array}{l}-1.59 \\
(0.95)\end{array}$ & $\begin{array}{l}-1.76 \\
(1.19)\end{array}$ & $\begin{array}{l}-1.43 \\
(0.94)\end{array}$ & $\begin{array}{l}-1.52 \\
(0.96)\end{array}$ \\
\hline Top 10 & $\begin{array}{l}-0.26 \\
(0.35)\end{array}$ & $\begin{array}{l}-0.31 \\
(0.34)\end{array}$ & $\begin{array}{l}-0.22 \\
(0.32)\end{array}$ & $\begin{array}{l}-0.26 \\
(0.35)\end{array}$ & $\begin{array}{l}-0.24 \\
(0.33)\end{array}$ & $\begin{array}{l}-0.23 \\
(0.34)\end{array}$ \\
\hline \multicolumn{7}{|l|}{ Payroll } \\
\hline$\overline{\text { Bottom } 90}$ & $\begin{array}{c}-8.78^{* * *} \\
(2.95)\end{array}$ & $\begin{array}{c}-8.36^{* * *} \\
(2.55)\end{array}$ & $\begin{array}{c}-8.72^{* * *} \\
(2.54)\end{array}$ & $\begin{array}{c}-8.80 * * * \\
(2.95)\end{array}$ & $\begin{array}{c}-7.49^{* * *} \\
(2.38)\end{array}$ & $\begin{array}{c}-8.36^{* * *} \\
(2.61)\end{array}$ \\
\hline Top 10 & $\begin{array}{c}0.09 \\
(1.10)\end{array}$ & $\begin{array}{l}-0.13 \\
(0.83)\end{array}$ & $\begin{array}{c}0.45 \\
(0.90)\end{array}$ & $\begin{array}{c}0.09 \\
(1.10)\end{array}$ & $\begin{array}{c}0.32 \\
(0.95)\end{array}$ & $\begin{array}{c}0.34 \\
(1.03)\end{array}$ \\
\hline \multicolumn{7}{|l|}{ Net Earnings } \\
\hline Bottom 90 & $\begin{array}{c}-11.58^{* * *} \\
(2.11)\end{array}$ & $\begin{array}{c}-10.34^{* * *} \\
(1.96)\end{array}$ & $\begin{array}{c}-10.86^{* * *} \\
(1.99)\end{array}$ & $\begin{array}{c}-11.57^{* * *} \\
(2.11)\end{array}$ & $\begin{array}{c}-9.88^{* * *} \\
(1.77)\end{array}$ & $\begin{array}{c}-10.56^{* * *} \\
(1.94)\end{array}$ \\
\hline Top 10 & $\begin{array}{c}0.59 \\
(0.73)\end{array}$ & $\begin{array}{c}0.57 \\
(0.79)\end{array}$ & $\begin{array}{c}0.83 \\
(0.64)\end{array}$ & $\begin{array}{c}0.59 \\
(0.73)\end{array}$ & $\begin{array}{c}0.72 \\
(0.64)\end{array}$ & $\begin{array}{c}0.75 \\
(0.72)\end{array}$ \\
\hline \multicolumn{7}{|l|}{ Controls } \\
\hline 1) COLA & $\mathrm{Y}$ & $\mathrm{N}$ & $\mathrm{N}$ & $\mathrm{N}$ & $\mathrm{N}$ & $\mathrm{N}$ \\
\hline 2) SNAP Benefits $x$ State & $\mathrm{N}$ & Y & $\mathrm{N}$ & $\mathrm{N}$ & $\mathrm{N}$ & $\mathrm{N}$ \\
\hline 3) SNAP Benefits Per Household & $\mathrm{N}$ & $\mathrm{N}$ & Y & $\mathrm{N}$ & $\mathrm{N}$ & $\mathrm{N}$ \\
\hline 4) FPL $x$ State & $\mathrm{N}$ & $\mathrm{N}$ & $\mathrm{N}$ & Y & $\mathrm{N}$ & $\mathrm{N}$ \\
\hline 5) FMAP & $\mathrm{N}$ & $\mathrm{N}$ & $\mathrm{N}$ & $\mathrm{N}$ & $\mathrm{Y}$ & $\mathrm{N}$ \\
\hline 6) Max AFDC + TANF Benefits & $\mathrm{N}$ & $\mathrm{N}$ & $\mathrm{N}$ & $\mathrm{N}$ & $\mathrm{N}$ & $\mathrm{Y}$ \\
\hline
\end{tabular}

Notes: This table presents state-level estimates of two-year changes in taxes for different groups on economic activity using a variety of ways to account for sensitivity to state-specific policies. Each specification is the same as column 1 in Table 1 with additional controls. Column 1 controls for the annual cost of living adjustment (COLA). Columns 2 and 3 control for the ratio of total Supplemental Nutrition Assistance Program (SNAP) benefits to GDP, calculated in different ways. Column 4 controls for the Federal Poverty Level (FPL) interacted with state dummies. Column 5 controls for the Federal Medical Assistance Percentage (FMAP). Column 6 controls for total AFDC and TANF payments, as determined by the maximum payment for the modal households. See sections A.2 and A.3 for more details on these controls. Standard errors are clustered by state $\left(* * * \mathrm{p}<0.01,{ }^{* *}\right.$ $\mathrm{p}<0.05, * \mathrm{p}<0.1)$. The sample period is $1980-2007$. 
Table A6: State-level Effects of Tax Changes by Income Group on Economic Activity: Cyclical Robustness

\begin{tabular}{|c|c|c|c|c|c|c|c|c|c|c|c|c|}
\hline & $\overline{~(1)}$ & $(2)$ & $(3)$ & $\overline{(4)}$ & $(5)$ & 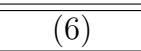 & 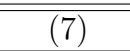 & 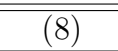 & $\overline{(9)}$ & (10) & (11) & $(12)$ \\
\hline \multicolumn{13}{|l|}{ Employment Rate } \\
\hline Bottom 90 & $\begin{array}{c}-1.74^{* *} \\
(0.79)\end{array}$ & $\begin{array}{c}-2.39^{* * *} \\
(0.73)\end{array}$ & $\begin{array}{c}-1.80^{* *} \\
(0.73)\end{array}$ & $\begin{array}{c}-1.89^{* *} \\
(0.80)\end{array}$ & $\begin{array}{c}-1.42^{* *} \\
(0.56)\end{array}$ & $\begin{array}{c}-2.33^{* * *} \\
(0.78)\end{array}$ & $\begin{array}{c}-2.44^{* * *} \\
(0.83)\end{array}$ & $\begin{array}{c}-2.26^{* *} \\
(0.79)\end{array}$ & $\begin{array}{c}-2.54^{* *} \\
(0.81)\end{array}$ & $\begin{array}{l}-1.70^{*} \\
(0.95)\end{array}$ & $\begin{array}{c}-2.01^{* *} \\
(0.72)\end{array}$ & $\begin{array}{l}-1.95^{*} \\
(0.99)\end{array}$ \\
\hline Top 10 & $\begin{array}{c}0.05 \\
(0.21)\end{array}$ & $\begin{array}{c}0.14 \\
(0.21)\end{array}$ & $\begin{array}{c}0.14 \\
(0.22)\end{array}$ & $\begin{array}{l}-0.32 \\
(0.23)\end{array}$ & $\begin{array}{c}0.07 \\
(0.18)\end{array}$ & $\begin{array}{c}0.19 \\
(0.24)\end{array}$ & $\begin{array}{c}0.06 \\
(0.22)\end{array}$ & $\begin{array}{c}0.16 \\
(0.25)\end{array}$ & $\begin{array}{c}0.08 \\
(0.21)\end{array}$ & $\begin{array}{l}-0.01 \\
(0.23)\end{array}$ & $\begin{array}{l}-0.03 \\
(0.28)\end{array}$ & $\begin{array}{c}0.05 \\
(0.22)\end{array}$ \\
\hline \multicolumn{13}{|l|}{ Emp/Pop } \\
\hline$\overline{\text { Bottom } 90}$ & $\begin{array}{l}-1.53 \\
(0.96)\end{array}$ & $\begin{array}{l}-1.62^{*} \\
(0.89)\end{array}$ & $\begin{array}{l}-1.03 \\
(0.99)\end{array}$ & $\begin{array}{l}-1.08 \\
(0.97)\end{array}$ & $\begin{array}{l}-0.49 \\
(0.89)\end{array}$ & $\begin{array}{l}-1.59^{*} \\
(0.94)\end{array}$ & $\begin{array}{l}-1.54 \\
(0.94)\end{array}$ & $\begin{array}{l}-1.64 \\
(0.95)\end{array}$ & $\begin{array}{l}-1.88 \\
(1.05)\end{array}$ & $\begin{array}{l}-1.39 \\
(1.08)\end{array}$ & $\begin{array}{l}-1.73 \\
(1.45)\end{array}$ & $\begin{array}{l}-1.78 \\
(1.18)\end{array}$ \\
\hline Top 10 & $\begin{array}{l}-0.24 \\
(0.33)\end{array}$ & $\begin{array}{l}-0.12 \\
(0.33)\end{array}$ & $\begin{array}{c}0.02 \\
(0.39)\end{array}$ & $\begin{array}{l}-0.45 \\
(0.33)\end{array}$ & $\begin{array}{l}-0.24 \\
(0.31)\end{array}$ & $\begin{array}{l}-0.06 \\
(0.36)\end{array}$ & $\begin{array}{l}-0.20 \\
(0.34)\end{array}$ & $\begin{array}{l}-0.05 \\
(0.35)\end{array}$ & $\begin{array}{c}-0.11 \\
(0.36)\end{array}$ & $\begin{array}{l}-0.26 \\
(0.32)\end{array}$ & $\begin{array}{l}-0.25 \\
(0.38)\end{array}$ & $\begin{array}{l}-0.27 \\
(0.34)\end{array}$ \\
\hline \multicolumn{13}{|l|}{$\underline{\text { Payroll }}$} \\
\hline$\overline{\text { Bottom } 90}$ & $\begin{array}{c}-8.37^{* * * *} \\
(2.61)\end{array}$ & $\begin{array}{c}-7.45^{* *} \\
(3.10)\end{array}$ & $\begin{array}{l}-4.93^{*} \\
(2.55)\end{array}$ & $\begin{array}{c}-7.95^{* * *} \\
(2.20)\end{array}$ & $\begin{array}{l}-5.24^{*} \\
(2.80)\end{array}$ & $\begin{array}{c}-7.09^{* *} \\
(3.27)\end{array}$ & $\begin{array}{c}-7.56^{* *} \\
(2.91)\end{array}$ & $\begin{array}{l}-6.18 \\
(4.62)\end{array}$ & $\begin{array}{c}-7.71^{*} \\
(3.74)\end{array}$ & $\begin{array}{c}-8.17^{* *} \\
(3.06)\end{array}$ & $\begin{array}{l}-8.38^{*} \\
(3.80)\end{array}$ & $\begin{array}{c}-8.79 * * * \\
(2.94)\end{array}$ \\
\hline Top 10 & $\begin{array}{c}0.32 \\
(1.01)\end{array}$ & $\begin{array}{c}0.47 \\
(0.83)\end{array}$ & $\begin{array}{l}-0.07 \\
(0.85)\end{array}$ & $\begin{array}{l}-0.25 \\
(0.81)\end{array}$ & $\begin{array}{c}0.11 \\
(0.72)\end{array}$ & $\begin{array}{c}0.34 \\
(0.85)\end{array}$ & $\begin{array}{l}-0.12 \\
(0.70)\end{array}$ & $\begin{array}{c}0.34 \\
(0.84)\end{array}$ & $\begin{array}{l}-0.05 \\
(0.75)\end{array}$ & $\begin{array}{l}-0.09 \\
(1.03)\end{array}$ & $\begin{array}{l}-0.12 \\
(0.81)\end{array}$ & $\begin{array}{c}0.08 \\
(1.11)\end{array}$ \\
\hline \multicolumn{13}{|l|}{ Net Earnings } \\
\hline Bottom 90 & $\begin{array}{c}-10.59^{* * *} \\
(1.95)\end{array}$ & $\begin{array}{c}-7.99^{* *} \\
(3.30)\end{array}$ & $\begin{array}{c}-5.10^{*} \\
(2.56)\end{array}$ & $\begin{array}{c}-10.84^{* * *} \\
(1.91)\end{array}$ & $\begin{array}{c}-6.73^{* *} \\
(2.75)\end{array}$ & $\begin{array}{c}-7.79^{* *} \\
(3.39)\end{array}$ & $\begin{array}{c}-7.89^{* *} \\
(3.25)\end{array}$ & $\begin{array}{l}-6.28 \\
(4.50)\end{array}$ & $\begin{array}{c}-8.00^{*} \\
(3.86)\end{array}$ & $\begin{array}{c}-10.15^{* * *} \\
(2.13)\end{array}$ & $\begin{array}{c}-9.94^{* * *} \\
(2.21)\end{array}$ & $\begin{array}{c}-11.47^{* * *} \\
(2.11)\end{array}$ \\
\hline Top 10 & $\begin{array}{c}0.73 \\
(0.70)\end{array}$ & $\begin{array}{c}0.89 \\
(0.87)\end{array}$ & $\begin{array}{c}0.19 \\
(0.85)\end{array}$ & $\begin{array}{l}-0.13 \\
(0.63)\end{array}$ & $\begin{array}{c}0.55 \\
(0.83)\end{array}$ & $\begin{array}{c}0.65 \\
(0.78)\end{array}$ & $\begin{array}{c}0.49 \\
(0.79)\end{array}$ & $\begin{array}{c}0.63 \\
(0.84)\end{array}$ & $\begin{array}{c}0.40 \\
(0.80)\end{array}$ & $\begin{array}{c}0.52 \\
(0.71)\end{array}$ & $\begin{array}{c}0.40 \\
(0.44)\end{array}$ & $\begin{array}{c}0.58 \\
(0.73)\end{array}$ \\
\hline \multicolumn{13}{|l|}{ Controls } \\
\hline 1) Baseline Cyclicality & $\mathrm{Y}$ & $\mathrm{N}$ & $\mathrm{N}$ & $\mathrm{N}$ & $\mathrm{N}$ & $\mathrm{N}$ & $\mathrm{N}$ & $\mathrm{N}$ & $\mathrm{N}$ & $\mathrm{Y}$ & $\mathrm{Y}$ & $\mathrm{Y}$ \\
\hline 2) Year & $\mathrm{N}$ & $\mathrm{Y}$ & $\mathrm{N}$ & $\mathrm{N}$ & $\mathrm{N}$ & $\mathrm{Y}$ & $\mathrm{Y}$ & $\mathrm{Y}$ & $\mathrm{Y}$ & $\mathrm{N}$ & $\mathrm{N}$ & $\mathrm{N}$ \\
\hline 3) $\sigma_{G D P P C}$ Cyclicality & $\mathrm{N}$ & $\mathrm{N}$ & $\mathrm{Y}$ & $\mathrm{N}$ & $\mathrm{N}$ & $\mathrm{N}$ & $\mathrm{N}$ & $\mathrm{N}$ & $\mathrm{N}$ & $\mathrm{N}$ & $\mathrm{N}$ & $\mathrm{N}$ \\
\hline 4) Alternate $\beta$-diff Control \#1 & $\mathrm{N}$ & $\mathrm{N}$ & $\mathrm{N}$ & $\mathrm{Y}$ & $\mathrm{N}$ & $\mathrm{N}$ & $\mathrm{N}$ & $\mathrm{N}$ & $\mathrm{N}$ & $\mathrm{N}$ & $\mathrm{N}$ & $\mathrm{N}$ \\
\hline 5) Alternate $\beta$-diff Control \#2 & $\mathrm{N}$ & $\mathrm{N}$ & $\mathrm{N}$ & $\mathrm{N}$ & $\mathrm{Y}$ & $\mathrm{N}$ & $\mathrm{N}$ & $\mathrm{N}$ & $\mathrm{N}$ & $\mathrm{N}$ & $\mathrm{N}$ & $\mathrm{N}$ \\
\hline 6) Oil Price $\mathrm{x}$ State & $\mathrm{N}$ & $\mathrm{N}$ & $\mathrm{N}$ & $\mathrm{N}$ & $\mathrm{N}$ & $\mathrm{Y}$ & $\mathrm{N}$ & $\mathrm{N}$ & $\mathrm{N}$ & $\mathrm{Y}$ & $\mathrm{N}$ & $\mathrm{N}$ \\
\hline 7) Real Interest Rate x State & $\mathrm{N}$ & $\mathrm{N}$ & $\mathrm{N}$ & $\mathrm{N}$ & $\mathrm{N}$ & $\mathrm{N}$ & $\mathrm{Y}$ & $\mathrm{N}$ & $\mathrm{N}$ & $\mathrm{Y}$ & $\mathrm{N}$ & $\mathrm{N}$ \\
\hline 8) Oil Price $x$ State + Region & $\mathrm{Y}$ & $\mathrm{N}$ & $\mathrm{N}$ & $\mathrm{N}$ & $\mathrm{N}$ & $\mathrm{N}$ & $\mathrm{N}$ & $\mathrm{Y}$ & $\mathrm{N}$ & $\mathrm{N}$ & $\mathrm{Y}$ & $\mathrm{N}$ \\
\hline 9) Real Interest Rate x State + Region & $\mathrm{N}$ & $\mathrm{N}$ & $\mathrm{N}$ & $\mathrm{N}$ & $\mathrm{N}$ & $\mathrm{N}$ & $\mathrm{N}$ & $\mathrm{N}$ & $\mathrm{Y}$ & $\mathrm{N}$ & $\mathrm{Y}$ & $\mathrm{N}$ \\
\hline 10) State Trends & $\mathrm{N}$ & $\mathrm{N}$ & $\mathrm{N}$ & $\mathrm{N}$ & $\mathrm{N}$ & $\mathrm{N}$ & $\mathrm{N}$ & $\mathrm{N}$ & $\mathrm{N}$ & $\mathrm{N}$ & $\mathrm{N}$ & $\mathrm{Y}$ \\
\hline
\end{tabular}

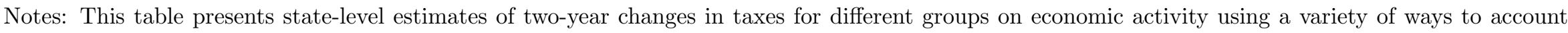

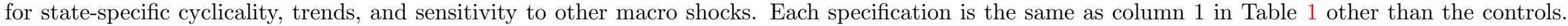

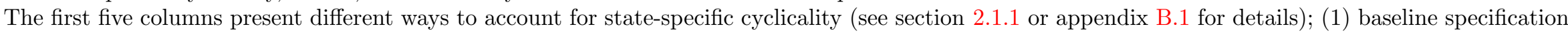

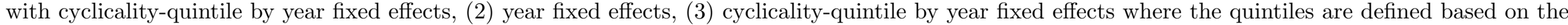

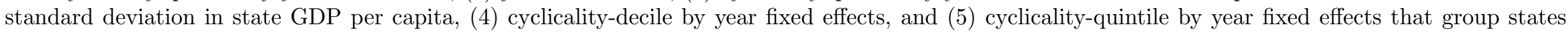

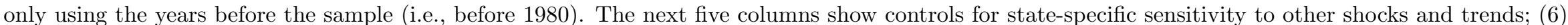

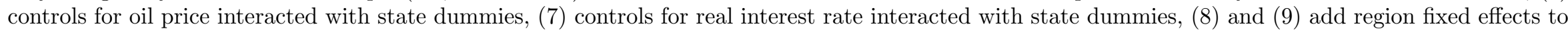

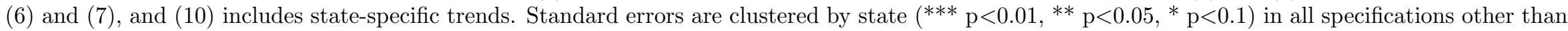
(8) and (9), which are clustered by region. The sample period is 1980-2007. See appendix A.2 for data definitions and sources. 
Table A7: State-level Effects of Tax Changes by Income Group on Economic Activity: Policy Robustness

\begin{tabular}{|c|c|c|c|c|c|c|c|c|c|c|c|c|}
\hline & $\overline{(1)}$ & (2) & (3) & $(4)$ & $(5)$ & (6) & (7) & $(8)$ & 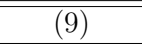 & 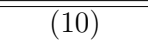 & (11) & $\overline{(12)}$ \\
\hline \multicolumn{13}{|l|}{ Employment Rate } \\
\hline Bottom 90 & $\begin{array}{c}-1.68^{* *} \\
(0.80)\end{array}$ & $\begin{array}{c}-1.77^{* *} \\
(0.79)\end{array}$ & $\begin{array}{c}-1.74^{* *} \\
(0.79)\end{array}$ & $\begin{array}{c}-1.74^{* *} \\
(0.79)\end{array}$ & $\begin{array}{c}-1.78^{* *} \\
(0.78)\end{array}$ & $\begin{array}{c}-1.74^{* *} \\
(0.79)\end{array}$ & $\begin{array}{c}-1.68^{* *} \\
(0.81)\end{array}$ & $\begin{array}{c}-1.75^{* *} \\
(0.80)\end{array}$ & $\begin{array}{c}-1.74^{* *} \\
(0.79)\end{array}$ & $\begin{array}{c}-1.78^{* *} \\
(0.79)\end{array}$ & $\begin{array}{c}-1.75^{* *} \\
(0.80)\end{array}$ & $\begin{array}{c}-1.78^{* *} \\
(0.80)\end{array}$ \\
\hline Top 10 & $\begin{array}{c}0.06 \\
(0.20)\end{array}$ & $\begin{array}{c}0.04 \\
(0.21)\end{array}$ & $\begin{array}{c}0.04 \\
(0.21)\end{array}$ & $\begin{array}{c}0.04 \\
(0.21)\end{array}$ & $\begin{array}{c}0.05 \\
(0.21)\end{array}$ & $\begin{array}{c}0.05 \\
(0.21)\end{array}$ & $\begin{array}{c}0.05 \\
(0.21)\end{array}$ & $\begin{array}{c}0.05 \\
(0.22)\end{array}$ & $\begin{array}{c}0.05 \\
(0.21)\end{array}$ & $\begin{array}{c}0.04 \\
(0.21)\end{array}$ & $\begin{array}{c}0.05 \\
(0.21)\end{array}$ & $\begin{array}{c}0.06 \\
(0.21)\end{array}$ \\
\hline \multicolumn{13}{|l|}{ Emp/Pop } \\
\hline$\overline{\text { Bottom } 90}$ & $\begin{array}{l}-1.35 \\
(0.95)\end{array}$ & $\begin{array}{l}-1.52 \\
(0.97)\end{array}$ & $\begin{array}{l}-1.53 \\
(0.96)\end{array}$ & $\begin{array}{l}-1.53 \\
(0.96)\end{array}$ & $\begin{array}{l}-1.59^{*} \\
(0.95)\end{array}$ & $\begin{array}{l}-1.53 \\
(0.96)\end{array}$ & $\begin{array}{l}-1.48 \\
(0.98)\end{array}$ & $\begin{array}{l}-1.52 \\
(0.96)\end{array}$ & $\begin{array}{l}-1.53 \\
(0.96)\end{array}$ & $\begin{array}{l}-1.52 \\
(0.98)\end{array}$ & $\begin{array}{l}-1.53 \\
(0.96)\end{array}$ & $\begin{array}{l}-1.53 \\
(0.98)\end{array}$ \\
\hline Top 10 & $\begin{array}{l}-0.20 \\
(0.30)\end{array}$ & $\begin{array}{l}-0.24 \\
(0.34)\end{array}$ & $\begin{array}{l}-0.24 \\
(0.33)\end{array}$ & $\begin{array}{l}-0.26 \\
(0.33)\end{array}$ & $\begin{array}{l}-0.23 \\
(0.33)\end{array}$ & $\begin{array}{l}-0.24 \\
(0.33)\end{array}$ & $\begin{array}{l}-0.24 \\
(0.33)\end{array}$ & $\begin{array}{l}-0.25 \\
(0.33)\end{array}$ & $\begin{array}{l}-0.24 \\
(0.33)\end{array}$ & $\begin{array}{l}-0.24 \\
(0.33)\end{array}$ & $\begin{array}{l}-0.24 \\
(0.33)\end{array}$ & $\begin{array}{l}-0.23 \\
(0.31)\end{array}$ \\
\hline \multicolumn{13}{|l|}{ Payroll } \\
\hline 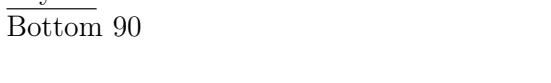 & $\begin{array}{c}-7.82^{* * *} \\
(2.55)\end{array}$ & $\begin{array}{c}-8.54^{* * *} \\
(2.62)\end{array}$ & $\begin{array}{c}-8.38^{* * *} \\
(2.61)\end{array}$ & $\begin{array}{c}-8.37^{* * *} \\
(2.61)\end{array}$ & $\begin{array}{c}-8.60 * * * \\
(2.53)\end{array}$ & $\begin{array}{c}-8.37^{* * * *} \\
(2.60)\end{array}$ & $\begin{array}{c}-8.54^{* * *} \\
(2.61)\end{array}$ & $\begin{array}{c}-8.30^{* * *} \\
(2.63)\end{array}$ & $\begin{array}{c}-8.38^{* * * *} \\
(2.61)\end{array}$ & $\begin{array}{c}-8.46^{* * *} \\
(2.61)\end{array}$ & $\begin{array}{c}-8.39 * * * \\
(2.62)\end{array}$ & $\begin{array}{c}-8.72^{* * *} \\
(2.58)\end{array}$ \\
\hline Top 10 & $\begin{array}{c}0.47 \\
(0.88)\end{array}$ & $\begin{array}{c}0.28 \\
(1.03)\end{array}$ & $\begin{array}{c}0.29 \\
(1.01)\end{array}$ & $\begin{array}{c}0.29 \\
(1.00)\end{array}$ & $\begin{array}{c}0.36 \\
(0.98)\end{array}$ & $\begin{array}{c}0.33 \\
(1.02)\end{array}$ & $\begin{array}{c}0.31 \\
(1.03)\end{array}$ & $\begin{array}{c}0.25 \\
(0.92)\end{array}$ & $\begin{array}{c}0.32 \\
(1.01)\end{array}$ & $\begin{array}{c}0.26 \\
(0.96)\end{array}$ & $\begin{array}{c}0.33 \\
(1.01)\end{array}$ & $\begin{array}{c}0.20 \\
(0.90)\end{array}$ \\
\hline \multicolumn{13}{|l|}{ Net Earnings } \\
\hline Bottom 90 & $\begin{array}{c}-10.21^{* * *} \\
(1.95)\end{array}$ & $\begin{array}{c}-10.72^{* * *} \\
(1.97)\end{array}$ & $\begin{array}{c}-10.59^{* * *} \\
(1.95)\end{array}$ & $\begin{array}{c}-10.59^{* * *} \\
(1.94)\end{array}$ & $\begin{array}{c}-10.65^{* * *} \\
(1.92)\end{array}$ & $\begin{array}{c}-10.59^{* * *} \\
(1.97)\end{array}$ & $\begin{array}{c}-10.55^{* * *} \\
(1.97)\end{array}$ & $\begin{array}{c}-10.53^{* * *} \\
(1.97)\end{array}$ & $\begin{array}{c}-10.59^{* * *} \\
(1.96)\end{array}$ & $\begin{array}{c}-10.65^{* * *} \\
(1.96)\end{array}$ & $\begin{array}{c}-10.59^{* * *} \\
(1.96)\end{array}$ & $\begin{array}{c}-10.57^{* * *} \\
(1.99)\end{array}$ \\
\hline Top 10 & $\begin{array}{c}0.83 \\
(0.63)\end{array}$ & $\begin{array}{c}0.69 \\
(0.69)\end{array}$ & $\begin{array}{c}0.75 \\
(0.72)\end{array}$ & $\begin{array}{c}0.69 \\
(0.68)\end{array}$ & $\begin{array}{c}0.74 \\
(0.69)\end{array}$ & $\begin{array}{c}0.73 \\
(0.70)\end{array}$ & $\begin{array}{c}0.73 \\
(0.69)\end{array}$ & $\begin{array}{c}0.67 \\
(0.67)\end{array}$ & $\begin{array}{c}0.73 \\
(0.70)\end{array}$ & $\begin{array}{c}0.69 \\
(0.68)\end{array}$ & $\begin{array}{c}0.73 \\
(0.70)\end{array}$ & $\begin{array}{c}0.67 \\
(0.65)\end{array}$ \\
\hline \multicolumn{13}{|l|}{ Controls } \\
\hline 1) Government Transfers Per Capita & Y & $\mathrm{N}$ & $\mathrm{N}$ & $\mathrm{N}$ & $\mathrm{N}$ & $\mathrm{N}$ & $\mathrm{N}$ & $\mathrm{N}$ & $\mathrm{N}$ & $\mathrm{N}$ & $\mathrm{N}$ & $\mathrm{N}$ \\
\hline 2) Federal IG Spending Per Capita & $\mathrm{N}$ & $\mathrm{Y}$ & $\mathrm{N}$ & $\mathrm{N}$ & $\mathrm{N}$ & $\mathrm{N}$ & $\mathrm{N}$ & $\mathrm{N}$ & $\mathrm{N}$ & $\mathrm{N}$ & $\mathrm{N}$ & $\mathrm{N}$ \\
\hline 3) Minimum Wage & $\mathrm{N}$ & $\mathrm{N}$ & $\mathrm{Y}$ & $\mathrm{N}$ & $\mathrm{N}$ & $\mathrm{N}$ & $\mathrm{N}$ & $\mathrm{N}$ & $\mathrm{N}$ & $\mathrm{N}$ & $\mathrm{N}$ & Y \\
\hline 4) OASDI & $\mathrm{N}$ & $\mathrm{N}$ & $\mathrm{N}$ & $\mathrm{Y}$ & $\mathrm{N}$ & $\mathrm{N}$ & $\mathrm{N}$ & $\mathrm{N}$ & $\mathrm{N}$ & $\mathrm{N}$ & $\mathrm{N}$ & $\mathrm{Y}$ \\
\hline 5) Supplemental Security Income & $\mathrm{N}$ & $\mathrm{N}$ & $\mathrm{N}$ & $\mathrm{N}$ & Y & $\mathrm{N}$ & $\mathrm{N}$ & $\mathrm{N}$ & $\mathrm{N}$ & $\mathrm{N}$ & $\mathrm{N}$ & $\mathrm{Y}$ \\
\hline 6) Max SNAP Benefits & $\mathrm{N}$ & $\mathrm{N}$ & $\mathrm{N}$ & $\mathrm{N}$ & $\mathrm{N}$ & $\mathrm{Y}$ & $\mathrm{N}$ & $\mathrm{N}$ & $\mathrm{N}$ & $\mathrm{N}$ & $\mathrm{N}$ & Y \\
\hline 7) Medicaid Benefits & $\mathrm{N}$ & $\mathrm{N}$ & $\mathrm{N}$ & $\mathrm{N}$ & $\mathrm{N}$ & $\mathrm{N}$ & $\mathrm{Y}$ & $\mathrm{N}$ & $\mathrm{N}$ & $\mathrm{N}$ & $\mathrm{N}$ & Y \\
\hline 8) AFDC + TANF Benefits & $\mathrm{N}$ & $\mathrm{N}$ & $\mathrm{N}$ & $\mathrm{N}$ & $\mathrm{N}$ & $\mathrm{N}$ & $\mathrm{N}$ & $\mathrm{Y}$ & $\mathrm{N}$ & $\mathrm{N}$ & $\mathrm{N}$ & $\mathrm{Y}$ \\
\hline 9) Mechanical Change in AFDC \& TANF & $\mathrm{N}$ & $\mathrm{N}$ & $\mathrm{N}$ & $\mathrm{N}$ & $\mathrm{N}$ & $\mathrm{N}$ & $\mathrm{N}$ & $\mathrm{N}$ & $\mathrm{Y}$ & $\mathrm{N}$ & $\mathrm{N}$ & $\mathrm{Y}$ \\
\hline 10) Mechanical Change in SNAP \& SSI & $\mathrm{N}$ & $\mathrm{N}$ & $\mathrm{N}$ & $\mathrm{N}$ & $\mathrm{N}$ & $\mathrm{N}$ & $\mathrm{N}$ & $\mathrm{N}$ & $\mathrm{N}$ & $\mathrm{Y}$ & $\mathrm{N}$ & $\mathrm{Y}$ \\
\hline 11) Mechanical Change in Medicaid & $\mathrm{N}$ & $\mathrm{N}$ & $\mathrm{N}$ & $\mathrm{N}$ & $\mathrm{N}$ & $\mathrm{N}$ & $\mathrm{N}$ & $\mathrm{N}$ & $\mathrm{N}$ & $\mathrm{N}$ & Y & $\mathrm{Y}$ \\
\hline
\end{tabular}

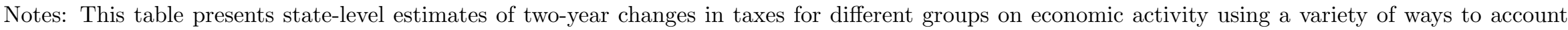

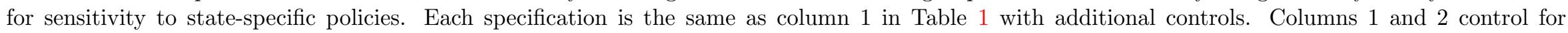

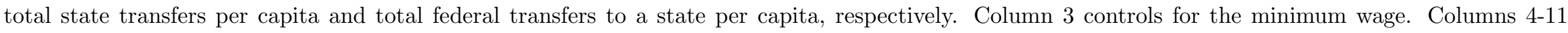

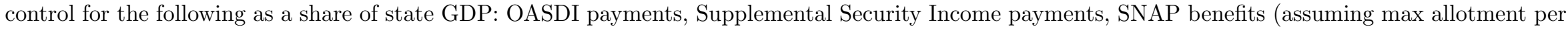

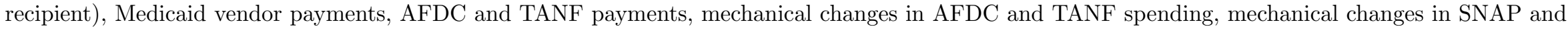

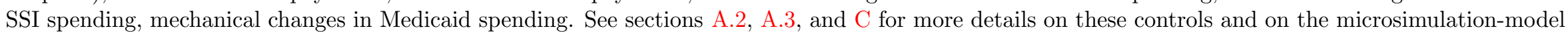
based mechanical changes. Standard errors are clustered by state $\left(* * * \mathrm{p}<0.01,{ }^{* *} \mathrm{p}<0.05,{ }^{*} \mathrm{p}<0.1\right)$. The sample period is $1980-2007$. 
Table A8: State-level Effects of Tax Changes by Income Group on State GDP: Cyclical Robustness

\begin{tabular}{|c|c|c|c|c|c|c|c|c|c|c|c|c|}
\hline & $(1)$ & $(2)$ & $(3)$ & $(4)$ & $(5)$ & $(6)$ & $(7)$ & $(8)$ & $(9)$ & $(10)$ & $(11)$ & $(12)$ \\
\hline \multicolumn{13}{|c|}{ Panel A: Distributed Lag Model of Tax Changes for Different Income Groups } \\
\hline$T_{s, t}^{B 90}$ & $\begin{array}{l}-2.05 \\
(2.18)\end{array}$ & $\begin{array}{l}-1.60 \\
(2.44)\end{array}$ & $\begin{array}{c}0.63 \\
(1.74)\end{array}$ & $\begin{array}{l}-1.76 \\
(2.33)\end{array}$ & $\begin{array}{l}-0.69 \\
(1.98)\end{array}$ & $\begin{array}{l}-1.91 \\
(2.75)\end{array}$ & $\begin{array}{l}-0.13 \\
(1.90)\end{array}$ & $\begin{array}{l}-1.25 \\
(3.81)\end{array}$ & $\begin{array}{l}-0.07 \\
(2.72)\end{array}$ & $\begin{array}{l}-1.06 \\
(2.36)\end{array}$ & $\begin{array}{l}-1.15 \\
(2.64)\end{array}$ & $\begin{array}{l}-1.65 \\
(2.48)\end{array}$ \\
\hline$T_{s, t-1}^{B 90}$ & $\begin{array}{c}-7.39 * * * \\
(1.34)\end{array}$ & $\begin{array}{c}-8.15^{* * *} \\
(1.95)\end{array}$ & $\begin{array}{c}-5.24^{* * *} \\
(1.30)\end{array}$ & $\begin{array}{c}-6.69 * * * \\
(1.15)\end{array}$ & $\begin{array}{c}-6.71^{* * *} \\
(1.50)\end{array}$ & $\begin{array}{c}-7.95^{* * *} \\
(2.11)\end{array}$ & $\begin{array}{c}-7.54^{* * *} \\
(1.83)\end{array}$ & $\begin{array}{c}-7.51^{* * *} \\
(2.82)\end{array}$ & $\begin{array}{c}-7.51^{* * *} \\
(2.23)\end{array}$ & $\begin{array}{c}-6.64^{* * *} \\
(1.32)\end{array}$ & $\begin{array}{c}-6.83^{* * *} \\
(1.61)\end{array}$ & $\begin{array}{c}-7.29^{* * *} \\
(1.32)\end{array}$ \\
\hline$T_{s, t-2}^{B 90}$ & $\begin{array}{c}0.25 \\
(1.44)\end{array}$ & $\begin{array}{l}-1.09 \\
(1.71)\end{array}$ & $\begin{array}{l}-0.85 \\
(1.34)\end{array}$ & $\begin{array}{l}-0.25 \\
(1.55)\end{array}$ & $\begin{array}{c}0.71 \\
(1.71)\end{array}$ & $\begin{array}{l}-0.75 \\
(1.80)\end{array}$ & $\begin{array}{l}-0.97 \\
(1.65)\end{array}$ & $\begin{array}{l}-0.56 \\
(2.39)\end{array}$ & $\begin{array}{l}-0.98 \\
(2.31)\end{array}$ & $\begin{array}{c}0.65 \\
(1.72)\end{array}$ & $\begin{array}{c}0.53 \\
(2.18)\end{array}$ & $\begin{array}{c}0.55 \\
(1.77)\end{array}$ \\
\hline$T_{s, t}^{T 110}$ & $\begin{array}{l}1.05^{*} \\
(0.58)\end{array}$ & $\begin{array}{c}0.96 \\
(0.60)\end{array}$ & $\begin{array}{c}0.55 \\
(0.64)\end{array}$ & $\begin{array}{c}0.53 \\
(0.63)\end{array}$ & $\begin{array}{l}1.02 \\
(0.64)\end{array}$ & $\begin{array}{c}0.90 \\
(0.61)\end{array}$ & $\begin{array}{c}0.66 \\
(0.52)\end{array}$ & $\begin{array}{c}0.85 \\
(0.60)\end{array}$ & $\begin{array}{c}0.74 \\
(0.54)\end{array}$ & $\begin{array}{c}0.95 \\
(0.61)\end{array}$ & $\begin{array}{c}0.90^{* * *} \\
(0.20)\end{array}$ & $\begin{array}{c}0.84 \\
(0.65)\end{array}$ \\
\hline$T_{s, t-1}^{T 10}$ & $\begin{array}{c}0.10 \\
(0.70)\end{array}$ & $\begin{array}{l}-0.08 \\
(0.58)\end{array}$ & $\begin{array}{l}-0.53 \\
(0.67)\end{array}$ & $\begin{array}{l}-0.11 \\
(0.62)\end{array}$ & $\begin{array}{l}0.03 \\
(0.57)\end{array}$ & $\begin{array}{l}-0.32 \\
(0.56)\end{array}$ & $\begin{array}{l}-0.59 \\
(0.61)\end{array}$ & $\begin{array}{l}-0.24 \\
(0.51)\end{array}$ & $\begin{array}{l}-0.48 \\
(0.53)\end{array}$ & $\begin{array}{l}-0.33 \\
(0.74)\end{array}$ & $\begin{array}{l}-0.25 \\
(0.52)\end{array}$ & $\begin{array}{l}-0.18 \\
(0.76)\end{array}$ \\
\hline$T_{s, t-2}^{T 10}$ & $\begin{array}{l}-0.12 \\
(0.57)\end{array}$ & $\begin{array}{l}-0.08 \\
(0.57)\end{array}$ & $\begin{array}{l}-0.65 \\
(0.57)\end{array}$ & $\begin{array}{l}-0.44 \\
(0.65)\end{array}$ & $\begin{array}{c}0.09 \\
(0.56)\end{array}$ & $\begin{array}{l}-0.47 \\
(0.54)\end{array}$ & $\begin{array}{l}-0.51 \\
(0.53)\end{array}$ & $\begin{array}{l}-0.24 \\
(0.36)\end{array}$ & $\begin{array}{l}-0.46 \\
(0.42) \\
\end{array}$ & $\begin{array}{l}-0.67 \\
(0.62)\end{array}$ & $\begin{array}{l}-0.59 \\
(0.36)\end{array}$ & $\begin{array}{l}-0.42 \\
(0.59)\end{array}$ \\
\hline B90 Sum: $\beta_{t}+\beta_{t-1}+\beta_{t-2}$ & $\begin{array}{c}-9.19^{* * *} \\
(3.40)\end{array}$ & $\begin{array}{c}-10.84^{* *} \\
(5.09)\end{array}$ & $\begin{array}{l}-5.45^{*} \\
(2.95)\end{array}$ & $\begin{array}{c}-8.70^{* *} \\
(3.44)\end{array}$ & $\begin{array}{l}-6.69^{*} \\
(3.94)\end{array}$ & $\begin{array}{c}-10.62^{*} \\
(5.69)\end{array}$ & $\begin{array}{c}-8.64^{* *} \\
(3.85)\end{array}$ & $\begin{array}{l}-9.31 \\
(7.66)\end{array}$ & $\begin{array}{l}-8.55 \\
(5.34)\end{array}$ & $\begin{array}{l}-7.04^{*} \\
(3.91)\end{array}$ & $\begin{array}{l}-7.45 \\
(4.50)\end{array}$ & $\begin{array}{l}-8.39^{*} \\
(4.27)\end{array}$ \\
\hline T10 Sum: $\beta_{t}+\beta_{t-1}+\beta_{t-2}$ & $\begin{array}{c}1.03 \\
(1.56)\end{array}$ & $\begin{array}{c}0.81 \\
(1.44)\end{array}$ & $\begin{array}{l}-0.64 \\
(1.52)\end{array}$ & $\begin{array}{l}-0.02 \\
(1.48)\end{array}$ & $\begin{array}{l}1.14 \\
(1.50)\end{array}$ & $\begin{array}{c}0.12 \\
(1.36)\end{array}$ & $\begin{array}{l}-0.44 \\
(1.29)\end{array}$ & $\begin{array}{c}0.37 \\
(1.13)\end{array}$ & $\begin{array}{l}-0.21 \\
(1.13)\end{array}$ & $\begin{array}{l}-0.05 \\
(1.68)\end{array}$ & $\begin{array}{c}0.06 \\
(0.75)\end{array}$ & $\begin{array}{c}0.24 \\
(1.71)\end{array}$ \\
\hline Bottom - Top: & $\begin{array}{c}-10.22^{* *} \\
(3.96)\end{array}$ & $\begin{array}{c}-11.65^{* *} \\
(5.48)\end{array}$ & $\begin{array}{l}-4.81 \\
(3.50)\end{array}$ & $\begin{array}{l}-8.69^{* *} \\
(3.75)\end{array}$ & $\begin{array}{l}-7.83^{*} \\
(4.45)\end{array}$ & $\begin{array}{c}-10.73^{*} \\
(5.98)\end{array}$ & $\begin{array}{l}-8.20^{*} \\
(4.42)\end{array}$ & $\begin{array}{l}-9.68 \\
(8.18)\end{array}$ & $\begin{array}{l}-8.35 \\
(6.02)\end{array}$ & $\begin{array}{l}-6.99 \\
(4.45)\end{array}$ & $\begin{array}{l}-7.51 \\
(4.88)\end{array}$ & $\begin{array}{l}-8.63^{*} \\
(4.84)\end{array}$ \\
\hline \multicolumn{13}{|c|}{ Panel B: Two-Year Changes } \\
\hline Bottom 90 & $\begin{array}{c}-11.98^{* * *} \\
(2.21)\end{array}$ & $\begin{array}{c}-13.16^{* * *} \\
(4.17)\end{array}$ & $\begin{array}{c}-7.60^{* * *} \\
(2.37)\end{array}$ & $\begin{array}{c}-11.71^{* * *} \\
(2.21)\end{array}$ & $\begin{array}{c}-9.81^{* * *} \\
(3.05)\end{array}$ & $\begin{array}{c}-12.81^{* * *} \\
(4.46)\end{array}$ & $\begin{array}{c}-12.78^{* * *} \\
(3.79)\end{array}$ & $\begin{array}{c}-11.70^{*} \\
(5.89)\end{array}$ & $\begin{array}{c}-12.36^{* *} \\
(4.77)\end{array}$ & $\begin{array}{c}-11.64^{* * *} \\
(2.28)\end{array}$ & $\begin{array}{c}-11.58^{* * *} \\
(2.29)\end{array}$ & $\begin{array}{c}-11.98^{* * *} \\
(2.20)\end{array}$ \\
\hline Top 10 & $\begin{array}{c}0.75 \\
(0.96)\end{array}$ & $\begin{array}{c}0.90 \\
(1.07)\end{array}$ & $\begin{array}{l}-0.10 \\
(1.02)\end{array}$ & $\begin{array}{c}0.18 \\
(0.86)\end{array}$ & $\begin{array}{l}0.74 \\
(1.02)\end{array}$ & $\begin{array}{c}0.53 \\
(0.99)\end{array}$ & $\begin{array}{l}0.26 \\
(0.89) \\
\end{array}$ & $\begin{array}{c}0.65 \\
(1.04)\end{array}$ & $\begin{array}{l}0.32 \\
(0.98) \\
\end{array}$ & $\begin{array}{c}0.24 \\
(1.01) \\
\end{array}$ & $\begin{array}{c}0.31 \\
(0.60)\end{array}$ & $\begin{array}{c}0.38 \\
(1.04)\end{array}$ \\
\hline P-Value (Bottom $90=$ Top 10) & 0.00 & 0.00 & 0.01 & 0.00 & 0.00 & 0.01 & 0.00 & 0.08 & 0.04 & 0.00 & 0.00 & 0.00 \\
\hline \multicolumn{13}{|l|}{ Controls } \\
\hline 1) Baseline Cyclicality & Y & $\mathrm{N}$ & $\mathrm{N}$ & $\mathrm{N}$ & $\mathrm{N}$ & $\mathrm{N}$ & $\mathrm{N}$ & $\mathrm{N}$ & $\mathrm{N}$ & Y & $\mathrm{Y}$ & Y \\
\hline 2) Year & $\mathrm{N}$ & Y & $\mathrm{N}$ & $\mathrm{N}$ & $\mathrm{N}$ & Y & $\mathrm{Y}$ & Y & $\mathrm{Y}$ & $\mathrm{N}$ & $\mathrm{N}$ & $\mathrm{N}$ \\
\hline 3) $\sigma_{G D P P C}$ Cyclicality & $\mathrm{N}$ & $\mathrm{N}$ & Y & $\mathrm{N}$ & $\mathrm{N}$ & $\mathrm{N}$ & $\mathrm{N}$ & $\mathrm{N}$ & $\mathrm{N}$ & $\mathrm{N}$ & $\mathrm{N}$ & $\mathrm{N}$ \\
\hline 4) Alternate $\beta$-diff Control \#1 & $\mathrm{N}$ & $\mathrm{N}$ & $\mathrm{N}$ & Y & $\mathrm{N}$ & $\mathrm{N}$ & $\mathrm{N}$ & $\mathrm{N}$ & $\mathrm{N}$ & $\mathrm{N}$ & $\mathrm{N}$ & $\mathrm{N}$ \\
\hline 5) Alternate $\beta$-diff Control \#2 & $\mathrm{N}$ & $\mathrm{N}$ & $\mathrm{N}$ & $\mathrm{N}$ & Y & $\mathrm{N}$ & $\mathrm{N}$ & $\mathrm{N}$ & $\mathrm{N}$ & $\mathrm{N}$ & $\mathrm{N}$ & $\mathrm{N}$ \\
\hline 6) Oil Price $x$ State & $\mathrm{N}$ & $\mathrm{N}$ & $\mathrm{N}$ & $\mathrm{N}$ & $\mathrm{N}$ & Y & $\mathrm{N}$ & $\mathrm{N}$ & $\mathrm{N}$ & Y & $\mathrm{N}$ & $\mathrm{N}$ \\
\hline 7) Real Interest Rate $x$ State & $\mathrm{N}$ & $\mathrm{N}$ & $\mathrm{N}$ & $\mathrm{N}$ & $\mathrm{N}$ & $\mathrm{N}$ & Y & $\mathrm{N}$ & $\mathrm{N}$ & Y & $\mathrm{N}$ & $\mathrm{N}$ \\
\hline 8) Oil Price $x$ State + Region & Y & $\mathrm{N}$ & $\mathrm{N}$ & $\mathrm{N}$ & $\mathrm{N}$ & $\mathrm{N}$ & $\mathrm{N}$ & Y & $\mathrm{N}$ & $\mathrm{N}$ & $\mathrm{Y}$ & $\mathrm{N}$ \\
\hline 9) Real Interest Rate $x$ State + Region & $\mathrm{N}$ & $\mathrm{N}$ & $\mathrm{N}$ & $\mathrm{N}$ & $\mathrm{N}$ & $\mathrm{N}$ & $\mathrm{N}$ & $\mathrm{N}$ & Y & $\mathrm{N}$ & Y & $\mathrm{N}$ \\
\hline 10) State Trends & $\mathrm{N}$ & $\mathrm{N}$ & $\mathrm{N}$ & $\mathrm{N}$ & $\mathrm{N}$ & $\mathrm{N}$ & $\mathrm{N}$ & $\mathrm{N}$ & $\mathrm{N}$ & $\mathrm{N}$ & $\mathrm{N}$ & Y \\
\hline
\end{tabular}

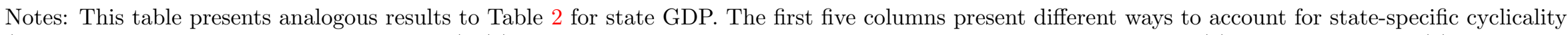

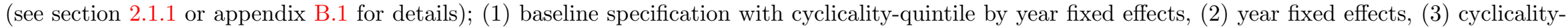

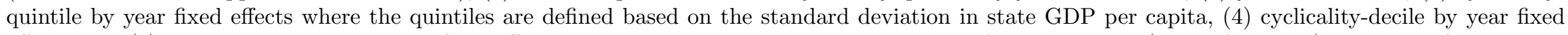

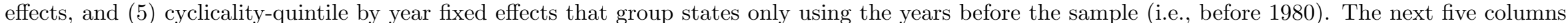

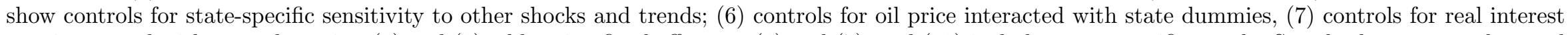

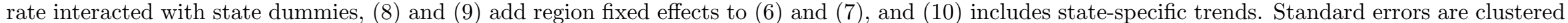

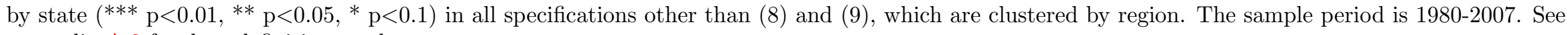
appendix A.2 for data definitions and sources. 
Table A9: State-level Effects of Tax Changes by Income Group on State GDP: Policy Robustness

\begin{tabular}{|c|c|c|c|c|c|c|c|c|c|c|c|c|}
\hline & $(1)$ & $(2)$ & $(3)$ & $(4)$ & $(5)$ & 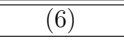 & $(7)$ & $(8)$ & $(9)$ & $(10)$ & $(\overline{l 11)}$ & $(12)$ \\
\hline \multicolumn{13}{|c|}{ Panel A: Distributed Lag Model of Tax Changes for Different Income Groups } \\
\hline$T_{s, t}^{B 90}$ & $\begin{array}{l}-2.06 \\
(2.11)\end{array}$ & $\begin{array}{l}-2.27 \\
(2.17)\end{array}$ & $\begin{array}{l}-2.07 \\
(2.18)\end{array}$ & $\begin{array}{l}-2.58 \\
(2.13)\end{array}$ & $\begin{array}{l}-1.41 \\
(1.81)\end{array}$ & $\begin{array}{l}-3.07 \\
(2.00)\end{array}$ & $\begin{array}{l}-2.11 \\
(2.08)\end{array}$ & $\begin{array}{l}-1.57 \\
(2.18)\end{array}$ & $\begin{array}{l}-2.10 \\
(2.20)\end{array}$ & $\begin{array}{l}-2.31 \\
(2.15)\end{array}$ & $\begin{array}{l}-2.03 \\
(2.19)\end{array}$ & $\begin{array}{l}-2.12 \\
(1.85)\end{array}$ \\
\hline$T_{s, t-1}^{B 90}$ & $\begin{array}{c}-7.54^{* * *} \\
(1.48)\end{array}$ & $\begin{array}{c}-7.45^{* * *} \\
(1.36)\end{array}$ & $\begin{array}{c}-7.31^{* * *} \\
(1.34)\end{array}$ & $\begin{array}{c}-6.39^{* * *} \\
(1.33)\end{array}$ & $\begin{array}{c}-5.14^{* * *} \\
(1.20)\end{array}$ & $\begin{array}{c}-6.59^{* * *} \\
(1.30)\end{array}$ & $\begin{array}{c}-7.19^{* * *} \\
(1.37)\end{array}$ & $\begin{array}{c}-6.91^{* * *} \\
(1.26)\end{array}$ & $\begin{array}{c}-7.28^{* * *} \\
(1.33)\end{array}$ & $\begin{array}{c}-7.91 * * * \\
(1.41)\end{array}$ & $\begin{array}{c}-7.36^{* * *} \\
(1.35)\end{array}$ & $\begin{array}{c}-4.13^{* * *} \\
(1.34)\end{array}$ \\
\hline$T_{s, t-2}^{B 90}$ & $\begin{array}{c}0.38 \\
(1.37)\end{array}$ & $\begin{array}{c}0.11 \\
(1.44)\end{array}$ & $\begin{array}{c}0.30 \\
(1.43)\end{array}$ & $\begin{array}{c}2.15 \\
(1.48)\end{array}$ & $\begin{array}{c}0.43 \\
(1.35)\end{array}$ & $\begin{array}{c}0.15 \\
(1.44)\end{array}$ & $\begin{array}{l}-0.16 \\
(1.42)\end{array}$ & $\begin{array}{c}0.54 \\
(1.42)\end{array}$ & $\begin{array}{c}0.19 \\
(1.45)\end{array}$ & $\begin{array}{c}0.30 \\
(1.40)\end{array}$ & $\begin{array}{c}0.28 \\
(1.44)\end{array}$ & $\begin{array}{c}1.12 \\
(1.24)\end{array}$ \\
\hline$T_{s, t}^{T 10}$ & $\begin{array}{c}0.94 \\
(0.57)\end{array}$ & $\begin{array}{l}1.03^{*} \\
(0.59)\end{array}$ & $\begin{array}{l}1.04^{*} \\
(0.58)\end{array}$ & $\begin{array}{l}0.97^{*} \\
(0.56)\end{array}$ & $\begin{array}{c}0.98 \\
(0.68)\end{array}$ & $\begin{array}{c}1.39^{* * *} \\
(0.42)\end{array}$ & $\begin{array}{c}0.86 \\
(0.58)\end{array}$ & $\begin{array}{l}1.00^{*} \\
(0.57)\end{array}$ & $\begin{array}{l}1.05^{*} \\
(0.58)\end{array}$ & $\begin{array}{l}1.02^{* *} \\
(0.49)\end{array}$ & $\begin{array}{l}1.07^{*} \\
(0.58)\end{array}$ & $\begin{array}{l}0.77^{*} \\
(0.46)\end{array}$ \\
\hline$T_{s, t-1}^{T 10}$ & $\begin{array}{c}0.15 \\
(0.62)\end{array}$ & $\begin{array}{c}0.06 \\
(0.70)\end{array}$ & $\begin{array}{c}0.11 \\
(0.71)\end{array}$ & $\begin{array}{c}0.12 \\
(0.65)\end{array}$ & $\begin{array}{c}0.30 \\
(0.54)\end{array}$ & $\begin{array}{c}0.18 \\
(0.52)\end{array}$ & $\begin{array}{c}0.07 \\
(0.70)\end{array}$ & $\begin{array}{c}0.16 \\
(0.64)\end{array}$ & $\begin{array}{c}0.09 \\
(0.71)\end{array}$ & $\begin{array}{c}0.08 \\
(0.66)\end{array}$ & $\begin{array}{c}0.08 \\
(0.70)\end{array}$ & $\begin{array}{c}0.26 \\
(0.40)\end{array}$ \\
\hline$T_{s, t-2}^{T 10}$ & $\begin{array}{c}0.05 \\
(0.53)\end{array}$ & $\begin{array}{l}-0.16 \\
(0.57)\end{array}$ & $\begin{array}{l}-0.10 \\
(0.56)\end{array}$ & $\begin{array}{l}-0.15 \\
(0.54)\end{array}$ & $\begin{array}{c}0.17 \\
(0.52)\end{array}$ & $\begin{array}{l}-0.15 \\
(0.43)\end{array}$ & $\begin{array}{l}-0.17 \\
(0.55)\end{array}$ & $\begin{array}{l}-0.02 \\
(0.53)\end{array}$ & $\begin{array}{l}-0.13 \\
(0.57)\end{array}$ & $\begin{array}{l}-0.22 \\
(0.53)\end{array}$ & $\begin{array}{l}-0.13 \\
(0.56)\end{array}$ & $\begin{array}{c}0.24 \\
(0.34)\end{array}$ \\
\hline B90 Sum: $\beta_{t}+\beta_{t-1}+\beta_{t-2}$ & $\begin{array}{c}-9.22^{* * *} \\
(3.03)\end{array}$ & $\begin{array}{c}-9.60^{* * *} \\
(3.43)\end{array}$ & $\begin{array}{c}-9.09^{* *} \\
(3.41)\end{array}$ & $\begin{array}{l}-6.82^{*} \\
(3.48)\end{array}$ & $\begin{array}{c}-6.13^{* *} \\
(2.63)\end{array}$ & $\begin{array}{c}-9.50^{* * *} \\
(3.18)\end{array}$ & $\begin{array}{c}-9.46^{* * *} \\
(3.33)\end{array}$ & $\begin{array}{c}-7.94^{* *} \\
(3.32)\end{array}$ & $\begin{array}{c}-9.18^{* * *} \\
(3.42)\end{array}$ & $\begin{array}{c}-9.92^{* * *} \\
(3.31)\end{array}$ & $\begin{array}{c}-9.11^{* *} \\
(3.42)\end{array}$ & $\begin{array}{c}-5.14^{* *} \\
(2.50)\end{array}$ \\
\hline T10 Sum: $\beta_{t}+\beta_{t-1}+\beta_{t-2}$ & $\begin{array}{c}1.14 \\
(1.35)\end{array}$ & $\begin{array}{c}0.93 \\
(1.58)\end{array}$ & $\begin{array}{l}1.05 \\
(1.56)\end{array}$ & $\begin{array}{c}0.95 \\
(1.48)\end{array}$ & $\begin{array}{c}1.45 \\
(1.56)\end{array}$ & $\begin{array}{c}1.43 \\
(1.04)\end{array}$ & $\begin{array}{l}0.76 \\
(1.55)\end{array}$ & $\begin{array}{c}1.14 \\
(1.43)\end{array}$ & $\begin{array}{l}1.01 \\
(1.56)\end{array}$ & $\begin{array}{c}0.89 \\
(1.39)\end{array}$ & $\begin{array}{c}1.02 \\
(1.56)\end{array}$ & $\begin{array}{c}1.27 \\
(0.96)\end{array}$ \\
\hline Bottom - Top: & $\begin{array}{c}-10.36^{* * * *} \\
(3.46)\end{array}$ & $\begin{array}{c}-10.54^{* *} \\
(4.03)\end{array}$ & $\begin{array}{c}-10.14^{* *} \\
(3.97)\end{array}$ & $\begin{array}{r}-7.77^{*} \\
(3.96)\end{array}$ & $\begin{array}{c}-7.58^{* *} \\
(3.09)\end{array}$ & $\begin{array}{c}-10.93^{* * *} \\
(3.39)\end{array}$ & $\begin{array}{c}-10.22^{* *} \\
(3.93)\end{array}$ & $\begin{array}{c}-9.08^{* *} \\
(3.77)\end{array}$ & $\begin{array}{c}-10.20^{* *} \\
(3.97)\end{array}$ & $\begin{array}{c}-10.82^{* * *} \\
(3.81)\end{array}$ & $\begin{array}{c}-10.13^{* *} \\
(3.97)\end{array}$ & $\begin{array}{c}-6.41^{* *} \\
(2.68)\end{array}$ \\
\hline \multicolumn{13}{|c|}{ Panel B: Two-Year Changes } \\
\hline Bottom 90 & $\begin{array}{c}-11.43^{* * *} \\
(2.17)\end{array}$ & $\begin{array}{c}-12.23^{* * *} \\
(2.23)\end{array}$ & $\begin{array}{c}-11.98^{* * *} \\
(2.21)\end{array}$ & $\begin{array}{c}-11.97^{* * *} \\
(2.18)\end{array}$ & $\begin{array}{c}-12.01^{* * *} \\
(2.14)\end{array}$ & $\begin{array}{c}-11.97^{* * *} \\
(2.22)\end{array}$ & $\begin{array}{c}-11.85^{* * *} \\
(2.21)\end{array}$ & $\begin{array}{c}-11.91^{* * *} \\
(2.23)\end{array}$ & $\begin{array}{c}-11.99^{* * *} \\
(2.21)\end{array}$ & $\begin{array}{c}-12.09^{* * *} \\
(2.19)\end{array}$ & $\begin{array}{c}-11.98^{* * *} \\
(2.21)\end{array}$ & $\begin{array}{c}-11.94^{* * *} \\
(2.16)\end{array}$ \\
\hline Top 10 & $\begin{array}{c}0.90 \\
(0.85)\end{array}$ & $\begin{array}{c}0.69 \\
(0.98)\end{array}$ & $\begin{array}{c}0.80 \\
(0.98)\end{array}$ & $\begin{array}{c}0.66 \\
(0.93)\end{array}$ & $\begin{array}{c}0.76 \\
(0.96)\end{array}$ & $\begin{array}{c}0.77 \\
(0.97)\end{array}$ & $\begin{array}{c}0.76 \\
(0.94)\end{array}$ & $\begin{array}{c}0.69 \\
(0.90)\end{array}$ & $\begin{array}{l}0.75 \\
(0.96)\end{array}$ & $\begin{array}{c}0.69 \\
(0.92)\end{array}$ & $\begin{array}{l}0.76 \\
(0.96)\end{array}$ & $\begin{array}{c}0.66 \\
(0.86)\end{array}$ \\
\hline P-Value (Bottom $90=$ Top 10) & 0.00 & 0.00 & 0.00 & 0.00 & 0.00 & 0.00 & 0.00 & 0.00 & 0.00 & 0.00 & 0.00 & 0.00 \\
\hline \multicolumn{13}{|l|}{ Controls } \\
\hline 1) Government Transfers Per Capita & Y & $\mathrm{N}$ & $\mathrm{N}$ & $\mathrm{N}$ & $\mathrm{N}$ & $\mathrm{N}$ & $\mathrm{N}$ & $\mathrm{N}$ & $\mathrm{N}$ & $\mathrm{N}$ & $\mathrm{N}$ & $\mathrm{N}$ \\
\hline 2) Federal IG Spending Per Capita & $\mathrm{N}$ & Y & $\mathrm{N}$ & $\mathrm{N}$ & $\mathrm{N}$ & $\mathrm{N}$ & $\mathrm{N}$ & $\mathrm{N}$ & $\mathrm{N}$ & $\mathrm{N}$ & $\mathrm{N}$ & $\mathrm{N}$ \\
\hline 3) Minimum Wage & $\mathrm{N}$ & $\mathrm{N}$ & $\mathrm{Y}$ & $\mathrm{N}$ & $\mathrm{N}$ & $\mathrm{N}$ & $\mathrm{N}$ & $\mathrm{N}$ & $\mathrm{N}$ & $\mathrm{N}$ & $\mathrm{N}$ & Y \\
\hline 4) OASDI & $\mathrm{N}$ & $\mathrm{N}$ & $\mathrm{N}$ & Y & $\mathrm{N}$ & $\mathrm{N}$ & $\mathrm{N}$ & $\mathrm{N}$ & $\mathrm{N}$ & $\mathrm{N}$ & $\mathrm{N}$ & Y \\
\hline 5) Supplemental Security Income & $\mathrm{N}$ & $\mathrm{N}$ & $\mathrm{N}$ & $\mathrm{N}$ & Y & $\mathrm{N}$ & $\mathrm{N}$ & $\mathrm{N}$ & $\mathrm{N}$ & $\mathrm{N}$ & $\mathrm{N}$ & Y \\
\hline 6) Max SNAP Benefits & $\mathrm{N}$ & $\mathrm{N}$ & $\mathrm{N}$ & $\mathrm{N}$ & $\mathrm{N}$ & Y & $\mathrm{N}$ & $\mathrm{N}$ & $\mathrm{N}$ & $\mathrm{N}$ & $\mathrm{N}$ & Y \\
\hline 7) Medicaid Benefits & $\mathrm{N}$ & $\mathrm{N}$ & $\mathrm{N}$ & $\mathrm{N}$ & $\mathrm{N}$ & $\mathrm{N}$ & Y & $\mathrm{N}$ & $\mathrm{N}$ & $\mathrm{N}$ & $\mathrm{N}$ & Y \\
\hline 8) AFDC + TANF Benefits & $\mathrm{N}$ & $\mathrm{N}$ & $\mathrm{N}$ & $\mathrm{N}$ & $\mathrm{N}$ & $\mathrm{N}$ & $\mathrm{N}$ & Y & $\mathrm{N}$ & $\mathrm{N}$ & $\mathrm{N}$ & Y \\
\hline 9) Mechanical Change in AFDC \& TANF & $\mathrm{N}$ & $\mathrm{N}$ & $\mathrm{N}$ & $\mathrm{N}$ & $\mathrm{N}$ & $\mathrm{N}$ & $\mathrm{N}$ & $\mathrm{N}$ & Y & $\mathrm{N}$ & $\mathrm{N}$ & Y \\
\hline 10) Mechanical Change in SNAP \& SSI & $\mathrm{N}$ & $\mathrm{N}$ & $\mathrm{N}$ & $\mathrm{N}$ & $\mathrm{N}$ & $\mathrm{N}$ & $\mathrm{N}$ & $\mathrm{N}$ & $\mathrm{N}$ & Y & $\mathrm{N}$ & Y \\
\hline 11) Mechanical Change in Medicaid & $\mathrm{N}$ & $\mathrm{N}$ & $\mathrm{N}$ & $\mathrm{N}$ & $\mathrm{N}$ & $\mathrm{N}$ & $\mathrm{N}$ & $\mathrm{N}$ & $\mathrm{N}$ & $\mathrm{N}$ & $\mathrm{Y}$ & $\mathrm{Y}$ \\
\hline
\end{tabular}

Notes: This table presents analogous results to Table 3 for state GDP. Columns 1 and 2 control for total state transfers per capita and total federal transfers to a state per capita, respectively. Column 3 controls for the minimum wage. Columns 4-11 control for the following as a share of state GDP: OASDI payments, Supplemental Security Income payments, SNAP benefits (assuming max allotment per recipient), Medicaid vendor payments, AFDC and TANF payments, mechanical changes in AFDC and TANF spending, mechanical changes in SNAP and SSI spending, mechanical changes in Medicaid spending. See sections A.2, A.3, and C for more details on these controls and on the microsimulation-model based mechanical changes. Standard errors are clustered by state $(* * * \mathrm{p}<0.01, * * \mathrm{p}<0.05, * \mathrm{p}<0.1)$. The sample period is $1980-2007$. 
Table A10: State-level Effects of Tax Changes by Income Group on Real State GDP: Cyclical Robustness

\begin{tabular}{|c|c|c|c|c|c|c|c|c|c|c|c|c|}
\hline & $(1)$ & $(2)$ & $(3)$ & $(4)$ & $(5)$ & $(6)$ & $(7)$ & $(8)$ & $(9)$ & $(10)$ & $(11)$ & $(12)$ \\
\hline \multicolumn{13}{|c|}{ Panel A: Distributed Lag Model of Tax Changes for Different Income Groups } \\
\hline$T_{s, t}^{B 90}$ & $\begin{array}{l}-0.29 \\
(2.83)\end{array}$ & $\begin{array}{c}0.02 \\
(2.52)\end{array}$ & $\begin{array}{c}3.44 \\
(2.21)\end{array}$ & $\begin{array}{l}-0.24 \\
(3.54)\end{array}$ & $\begin{array}{c}1.61 \\
(2.54)\end{array}$ & $\begin{array}{c}0.06 \\
(2.84)\end{array}$ & $\begin{array}{c}0.06 \\
(1.67)\end{array}$ & $\begin{array}{l}-0.12 \\
(4.03)\end{array}$ & $\begin{array}{c}0.24 \\
(1.91)\end{array}$ & $\begin{array}{c}0.17 \\
(3.37)\end{array}$ & $\begin{array}{l}-0.38 \\
(3.68)\end{array}$ & $\begin{array}{l}-1.46 \\
(3.39)\end{array}$ \\
\hline$T_{s, t-1}^{B 90}$ & $\begin{array}{c}-8.40 * * * \\
(2.85)\end{array}$ & $\begin{array}{c}-10.85^{* * *} \\
(2.87)\end{array}$ & $\begin{array}{c}-7.74^{* * *} \\
(1.95)\end{array}$ & $\begin{array}{c}-6.80^{* * *} \\
(2.36)\end{array}$ & $\begin{array}{c}-8.35 * * * \\
(2.74)\end{array}$ & $\begin{array}{c}-10.71^{* * *} \\
(2.97)\end{array}$ & $\begin{array}{c}-10.86^{* * * *} \\
(3.37)\end{array}$ & $\begin{array}{c}-10.65^{* *} \\
(4.20)\end{array}$ & $\begin{array}{c}-11.16^{* *} \\
(4.20)\end{array}$ & $\begin{array}{c}-8.19^{* *} \\
(3.18)\end{array}$ & $\begin{array}{c}-8.91^{* *} \\
(3.81)\end{array}$ & $\begin{array}{c}-9.11^{* * *} \\
(2.97)\end{array}$ \\
\hline$T_{s, t-2}^{B 90}$ & $\begin{array}{c}2.11 \\
(2.11)\end{array}$ & $\begin{array}{c}0.08 \\
(1.65)\end{array}$ & $\begin{array}{l}-0.33 \\
(1.99)\end{array}$ & $\begin{array}{c}3.52 \\
(2.66)\end{array}$ & $\begin{array}{c}2.36 \\
(2.09)\end{array}$ & $\begin{array}{c}-0.10 \\
(1.78)\end{array}$ & $\begin{array}{l}-1.09 \\
(2.69)\end{array}$ & $\begin{array}{c}-0.24 \\
(1.21)\end{array}$ & $\begin{array}{l}-1.09 \\
(1.45)\end{array}$ & $\begin{array}{l}1.17 \\
(2.64)\end{array}$ & $\begin{array}{l}1.08 \\
(2.40)\end{array}$ & $\begin{array}{l}1.64 \\
(2.65)\end{array}$ \\
\hline$T_{s, t}^{T 10}$ & $\begin{array}{c}0.91 \\
(0.99)\end{array}$ & $\begin{array}{c}1.49 \\
(1.12)\end{array}$ & $\begin{array}{c}0.58 \\
(1.03)\end{array}$ & $\begin{array}{c}1.49 \\
(0.97)\end{array}$ & $\begin{array}{c}1.33 \\
(1.07)\end{array}$ & $\begin{array}{c}1.48 \\
(1.17)\end{array}$ & $\begin{array}{c}1.02 \\
(0.96)\end{array}$ & $\begin{array}{c}1.36 \\
(1.15)\end{array}$ & $\begin{array}{c}1.12 \\
(0.95)\end{array}$ & $\begin{array}{c}0.62 \\
(1.04)\end{array}$ & $\begin{array}{c}0.67 \\
(0.91)\end{array}$ & $\begin{array}{c}0.68 \\
(0.96)\end{array}$ \\
\hline$T_{s, t-1}^{T 10}$ & $\begin{array}{c}0.88 \\
(0.61)\end{array}$ & $\begin{array}{c}0.91 \\
(0.78)\end{array}$ & $\begin{array}{c}0.40 \\
(0.70)\end{array}$ & $\begin{array}{l}1.37^{*} \\
(0.71)\end{array}$ & $\begin{array}{c}0.79 \\
(0.68)\end{array}$ & $\begin{array}{c}0.81 \\
(0.79)\end{array}$ & $\begin{array}{c}0.18 \\
(0.86)\end{array}$ & $\begin{array}{c}0.71 \\
(0.77)\end{array}$ & $\begin{array}{c}0.35 \\
(0.71)\end{array}$ & $\begin{array}{c}0.32 \\
(0.69)\end{array}$ & $\begin{array}{c}0.50 \\
(0.56)\end{array}$ & $\begin{array}{c}0.63 \\
(0.61)\end{array}$ \\
\hline$T_{s, t-2}^{T 10}$ & $\begin{array}{l}-0.12 \\
(0.77)\end{array}$ & $\begin{array}{l}-0.00 \\
(0.81)\end{array}$ & $\begin{array}{l}-0.37 \\
(0.89)\end{array}$ & $\begin{array}{l}-0.99 \\
(1.06)\end{array}$ & $\begin{array}{c}0.14 \\
(0.76)\end{array}$ & $\begin{array}{l}-0.21 \\
(0.84)\end{array}$ & $\begin{array}{l}-0.68 \\
(1.04)\end{array}$ & $\begin{array}{l}-0.19 \\
(0.75)\end{array}$ & $\begin{array}{l}-0.59 \\
(1.00) \\
\end{array}$ & $\begin{array}{l}-0.85 \\
(0.84) \\
\end{array}$ & $\begin{array}{l}-0.69 \\
(0.55) \\
\end{array}$ & $\begin{array}{l}-0.42 \\
(0.79) \\
\end{array}$ \\
\hline B90 Sum: $\beta_{t}+\beta_{t-1}+\beta_{t-2}$ & $\begin{array}{l}-6.59 \\
(4.97)\end{array}$ & $\begin{array}{c}-10.75^{* *} \\
(4.27)\end{array}$ & $\begin{array}{l}-4.62 \\
(3.88)\end{array}$ & $\begin{array}{l}-3.52 \\
(6.03)\end{array}$ & $\begin{array}{l}-4.39 \\
(4.85)\end{array}$ & $\begin{array}{c}-10.76^{* *} \\
(4.84)\end{array}$ & $\begin{array}{c}-11.89^{*} \\
(6.01)\end{array}$ & $\begin{array}{l}-11.01 \\
(6.73)\end{array}$ & $\begin{array}{c}-12.01^{* *} \\
(5.05)\end{array}$ & $\begin{array}{l}-6.85 \\
(6.66)\end{array}$ & $\begin{array}{l}-8.21 \\
(7.58)\end{array}$ & $\begin{array}{l}-8.92 \\
(6.68)\end{array}$ \\
\hline T10 Sum: $\beta_{t}+\beta_{t-1}+\beta_{t-2}$ & $\begin{array}{c}1.67 \\
(1.33)\end{array}$ & $\begin{array}{c}2.40 \\
(1.83)\end{array}$ & $\begin{array}{c}0.61 \\
(1.59)\end{array}$ & $\begin{array}{c}1.87 \\
(1.51)\end{array}$ & $\begin{array}{c}2.27 \\
(1.75)\end{array}$ & $\begin{array}{c}2.09 \\
(1.87)\end{array}$ & $\begin{array}{c}0.52 \\
(1.81)\end{array}$ & $\begin{array}{c}1.88 \\
(1.72)\end{array}$ & $\begin{array}{c}0.89 \\
(1.57)\end{array}$ & $\begin{array}{c}0.09 \\
(1.45)\end{array}$ & $\begin{array}{c}0.47 \\
(1.12)\end{array}$ & $\begin{array}{c}0.89 \\
(1.26)\end{array}$ \\
\hline Bottom - Top: & $\begin{array}{l}-8.26 \\
(5.10)\end{array}$ & $\begin{array}{c}-13.14^{* *} \\
(5.17)\end{array}$ & $\begin{array}{l}-5.23 \\
(4.33)\end{array}$ & $\begin{array}{l}-5.39 \\
(6.19)\end{array}$ & $\begin{array}{l}-6.66 \\
(5.42)\end{array}$ & $\begin{array}{c}-12.85^{* *} \\
(5.69)\end{array}$ & $\begin{array}{c}-12.41^{* *} \\
(5.74)\end{array}$ & $\begin{array}{r}-12.90 \\
(7.42)\end{array}$ & $\begin{array}{c}-12.90^{* *} \\
(5.29)\end{array}$ & $\begin{array}{l}-6.94 \\
(6.67)\end{array}$ & $\begin{array}{l}-8.68 \\
(7.29)\end{array}$ & $\begin{array}{l}-9.81 \\
(6.79)\end{array}$ \\
\hline \multicolumn{13}{|c|}{ Panel B: Two-Year Changes } \\
\hline Bottom 90 & $\begin{array}{c}-9.70^{* * *} \\
(3.46)\end{array}$ & $\begin{array}{c}-13.18^{* * *} \\
(3.53)\end{array}$ & $\begin{array}{c}-6.96^{* * *} \\
(2.36)\end{array}$ & $\begin{array}{c}-8.98^{* *} \\
(3.63)\end{array}$ & $\begin{array}{c}-8.05^{* *} \\
(3.39)\end{array}$ & $\begin{array}{c}-13.27^{* * *} \\
(3.82)\end{array}$ & $\begin{array}{c}-14.28^{* * *} \\
(3.78)\end{array}$ & $\begin{array}{c}-12.54^{*} \\
(5.66)\end{array}$ & $\begin{array}{c}-14.15^{* *} \\
(4.55)\end{array}$ & $\begin{array}{c}-10.22^{* *} \\
(4.06)\end{array}$ & $\begin{array}{c}-10.87^{* *} \\
(4.51)\end{array}$ & $\begin{array}{c}-11.32^{* * *} \\
(3.81)\end{array}$ \\
\hline Top 10 & $\begin{array}{l}1.44^{*} \\
(0.85)\end{array}$ & $\begin{array}{c}2.09 \\
(1.38)\end{array}$ & $\begin{array}{c}0.66 \\
(0.95)\end{array}$ & $\begin{array}{c}2.30^{* *} \\
(1.09)\end{array}$ & $\begin{array}{c}1.57 \\
(1.10)\end{array}$ & $\begin{array}{c}1.83 \\
(1.33)\end{array}$ & $\begin{array}{c}1.03 \\
(1.05)\end{array}$ & $\begin{array}{c}1.86 \\
(1.53)\end{array}$ & $\begin{array}{c}1.17 \\
(1.12)\end{array}$ & $\begin{array}{c}0.49 \\
(0.86)\end{array}$ & $\begin{array}{c}0.88 \\
(0.81)\end{array}$ & $\begin{array}{c}1.08 \\
(0.77)\end{array}$ \\
\hline P-Value (Bottom $90=$ Top 10) & 0.00 & 0.00 & 0.01 & 0.00 & 0.01 & 0.00 & 0.00 & 0.04 & 0.02 & 0.01 & 0.03 & 0.00 \\
\hline \multicolumn{13}{|l|}{ Controls } \\
\hline 1) Baseline Cyclicality & $\mathrm{Y}$ & $\mathrm{N}$ & $\mathrm{N}$ & $\mathrm{N}$ & $\mathrm{N}$ & $\mathrm{N}$ & $\mathrm{N}$ & $\mathrm{N}$ & $\mathrm{N}$ & $\mathrm{Y}$ & Y & $\mathrm{Y}$ \\
\hline 2) Year & $\mathrm{N}$ & Y & $\mathrm{N}$ & $\mathrm{N}$ & $\mathrm{N}$ & Y & Y & $\mathrm{Y}$ & $\mathrm{Y}$ & $\mathrm{N}$ & $\mathrm{N}$ & $\mathrm{N}$ \\
\hline 3) $\sigma_{G D P P C}$ Cyclicality & $\mathrm{N}$ & $\mathrm{N}$ & Y & $\mathrm{N}$ & $\mathrm{N}$ & $\mathrm{N}$ & $\mathrm{N}$ & $\mathrm{N}$ & $\mathrm{N}$ & $\mathrm{N}$ & $\mathrm{N}$ & $\mathrm{N}$ \\
\hline 4) Alternate $\beta$-diff Control \#1 & $\mathrm{N}$ & $\mathrm{N}$ & $\mathrm{N}$ & $\mathrm{Y}$ & $\mathrm{N}$ & $\mathrm{N}$ & $\mathrm{N}$ & $\mathrm{N}$ & $\mathrm{N}$ & $\mathrm{N}$ & $\mathrm{N}$ & $\mathrm{N}$ \\
\hline 5) Alternate $\beta$-diff Control \#2 & $\mathrm{N}$ & $\mathrm{N}$ & $\mathrm{N}$ & $\mathrm{N}$ & $\mathrm{Y}$ & $\mathrm{N}$ & $\mathrm{N}$ & $\mathrm{N}$ & $\mathrm{N}$ & $\mathrm{N}$ & $\mathrm{N}$ & $\mathrm{N}$ \\
\hline 6) Oil Price $x$ State & $\mathrm{N}$ & $\mathrm{N}$ & $\mathrm{N}$ & $\mathrm{N}$ & $\mathrm{N}$ & Y & $\mathrm{N}$ & $\mathrm{N}$ & $\mathrm{N}$ & Y & $\mathrm{N}$ & $\mathrm{N}$ \\
\hline 7) Real Interest Rate $x$ State & $\mathrm{N}$ & $\mathrm{N}$ & $\mathrm{N}$ & $\mathrm{N}$ & $\mathrm{N}$ & $\mathrm{N}$ & Y & $\mathrm{N}$ & $\mathrm{N}$ & Y & $\mathrm{N}$ & $\mathrm{N}$ \\
\hline 8) Oil Price $x$ State + Region & $\mathrm{Y}$ & $\mathrm{N}$ & $\mathrm{N}$ & $\mathrm{N}$ & $\mathrm{N}$ & $\mathrm{N}$ & $\mathrm{N}$ & Y & $\mathrm{N}$ & $\mathrm{N}$ & Y & $\mathrm{N}$ \\
\hline 9) Real Interest Rate $x$ State + Region & $\mathrm{N}$ & $\mathrm{N}$ & $\mathrm{N}$ & $\mathrm{N}$ & $\mathrm{N}$ & $\mathrm{N}$ & $\mathrm{N}$ & $\mathrm{N}$ & Y & $\mathrm{N}$ & Y & $\mathrm{N}$ \\
\hline 10) State Trends & $\mathrm{N}$ & $\mathrm{N}$ & $\mathrm{N}$ & $\mathrm{N}$ & $\mathrm{N}$ & $\mathrm{N}$ & $\mathrm{N}$ & $\mathrm{N}$ & $\mathrm{N}$ & $\mathrm{N}$ & $\mathrm{N}$ & $\mathrm{Y}$ \\
\hline
\end{tabular}

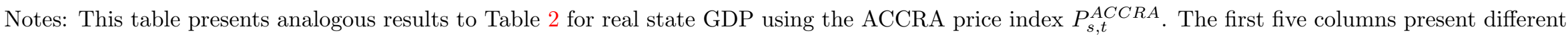

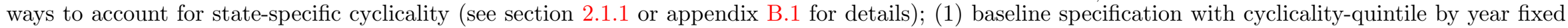

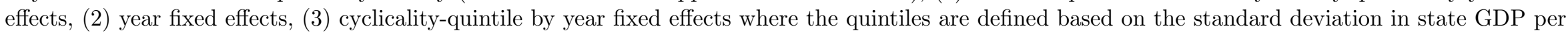

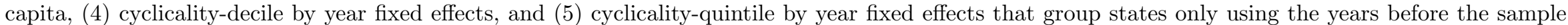

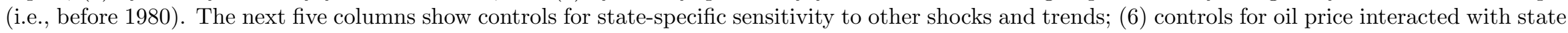

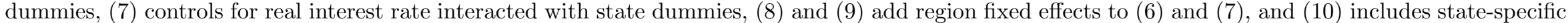

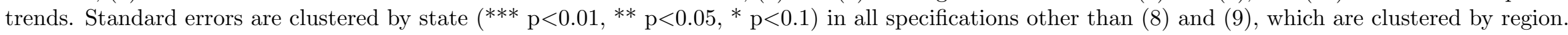
The sample period is 1980-2007. See appendix A.2 for data definitions and sources. 
Table A11: State-level Effects of Tax Changes by Income Group on Real State GDP: Policy Robustness

\begin{tabular}{|c|c|c|c|c|c|c|c|c|c|c|c|c|}
\hline & $(1)$ & $(2)$ & $(3)$ & $(4)$ & $(5)$ & $(6)$ & $(7)$ & $(8)$ & $(9)$ & $(10)$ & $(11)$ & $(12)$ \\
\hline \multicolumn{13}{|c|}{ Panel A: Distributed Lag Model of Tax Changes for Different Income Groups } \\
\hline$T_{s, t}^{B 90}$ & $\begin{array}{l}-0.32 \\
(2.83)\end{array}$ & $\begin{array}{l}-0.66 \\
(2.85)\end{array}$ & $\begin{array}{l}-0.66 \\
(2.92)\end{array}$ & $\begin{array}{l}-0.53 \\
(2.89)\end{array}$ & $\begin{array}{c}0.32 \\
(2.65)\end{array}$ & $\begin{array}{l}-1.09 \\
(2.81)\end{array}$ & $\begin{array}{l}-0.15 \\
(2.83)\end{array}$ & $\begin{array}{c}0.62 \\
(2.85)\end{array}$ & $\begin{array}{l}-0.42 \\
(2.83)\end{array}$ & $\begin{array}{l}-0.69 \\
(2.87)\end{array}$ & $\begin{array}{l}-0.50 \\
(2.85)\end{array}$ & $\begin{array}{l}-0.61 \\
(2.89)\end{array}$ \\
\hline$T_{s, t-1}^{B 90}$ & $\begin{array}{c}-8.61^{* * * *} \\
(2.97)\end{array}$ & $\begin{array}{c}-8.33^{* * *} \\
(2.97)\end{array}$ & $\begin{array}{c}-8.29 * * * \\
(2.89)\end{array}$ & $\begin{array}{c}-7.66^{* *} \\
(2.88)\end{array}$ & $\begin{array}{c}-6.28^{* *} \\
(2.52)\end{array}$ & $\begin{array}{c}-7.65^{* * *} \\
(2.71)\end{array}$ & $\begin{array}{c}-8.24^{* * *} \\
(2.90)\end{array}$ & $\begin{array}{c}-7.58^{* * *} \\
(2.68)\end{array}$ & $\begin{array}{c}-8.23^{* * *} \\
(2.85)\end{array}$ & $\begin{array}{c}-9.24^{* * *} \\
(3.00)\end{array}$ & $\begin{array}{c}-8.38^{* * *} \\
(2.86)\end{array}$ & $\begin{array}{c}-6.22^{* *} \\
(2.86)\end{array}$ \\
\hline$T_{s, t-2}^{B 90}$ & $\begin{array}{c}2.19 \\
(2.09)\end{array}$ & $\begin{array}{l}1.92 \\
(2.18)\end{array}$ & $\begin{array}{l}2.91 \\
(2.22)\end{array}$ & $\begin{array}{l}3.91^{*} \\
(2.01)\end{array}$ & $\begin{array}{c}2.21 \\
(1.93)\end{array}$ & $\begin{array}{l}1.97 \\
(2.08)\end{array}$ & $\begin{array}{c}1.87 \\
(2.12)\end{array}$ & $\begin{array}{c}2.58 \\
(1.96)\end{array}$ & $\begin{array}{c}2.09 \\
(2.11)\end{array}$ & $\begin{array}{c}2.36 \\
(2.05)\end{array}$ & $\begin{array}{c}2.22 \\
(2.08)\end{array}$ & $\begin{array}{l}3.29^{*} \\
(1.76)\end{array}$ \\
\hline$T_{s, t}^{T 10}$ & $\begin{array}{c}0.92 \\
(1.01)\end{array}$ & $\begin{array}{c}0.96 \\
(1.00)\end{array}$ & $\begin{array}{c}1.10 \\
(0.97)\end{array}$ & $\begin{array}{c}0.84 \\
(0.96)\end{array}$ & $\begin{array}{c}0.89 \\
(0.86)\end{array}$ & $\begin{array}{c}1.29 \\
(1.12)\end{array}$ & $\begin{array}{c}0.81 \\
(1.01)\end{array}$ & $\begin{array}{c}0.82 \\
(1.07)\end{array}$ & $\begin{array}{c}0.92 \\
(0.99)\end{array}$ & $\begin{array}{c}0.92 \\
(1.06)\end{array}$ & $\begin{array}{c}0.96 \\
(1.00)\end{array}$ & $\begin{array}{l}1.11 \\
(1.04)\end{array}$ \\
\hline$T_{s, t-1}^{T 10}$ & $\begin{array}{c}0.79 \\
(0.63)\end{array}$ & $\begin{array}{c}0.91 \\
(0.60)\end{array}$ & $\begin{array}{l}1.03^{*} \\
(0.58)\end{array}$ & $\begin{array}{c}0.86 \\
(0.59)\end{array}$ & $\begin{array}{l}1.10^{*} \\
(0.57)\end{array}$ & $\begin{array}{c}1.01 \\
(0.67)\end{array}$ & $\begin{array}{c}0.91 \\
(0.59)\end{array}$ & $\begin{array}{c}0.97 \\
(0.59)\end{array}$ & $\begin{array}{c}0.88 \\
(0.62)\end{array}$ & $\begin{array}{c}0.85 \\
(0.65)\end{array}$ & $\begin{array}{c}0.82 \\
(0.62)\end{array}$ & $\begin{array}{l}1.14^{*} \\
(0.66)\end{array}$ \\
\hline$T_{s, t-2}^{T 10}$ & $\begin{array}{l}-0.04 \\
(0.75)\end{array}$ & $\begin{array}{l}-0.12 \\
(0.76)\end{array}$ & $\begin{array}{l}-0.12 \\
(0.77)\end{array}$ & $\begin{array}{l}-0.21 \\
(0.76)\end{array}$ & $\begin{array}{c}0.14 \\
(0.83)\end{array}$ & $\begin{array}{l}-0.14 \\
(0.74)\end{array}$ & $\begin{array}{l}-0.08 \\
(0.77)\end{array}$ & $\begin{array}{c}0.01 \\
(0.78) \\
\end{array}$ & $\begin{array}{l}-0.15 \\
(0.76) \\
\end{array}$ & $\begin{array}{c}-0.21 \\
(0.71) \\
\end{array}$ & $\begin{array}{l}-0.16 \\
(0.76) \\
\end{array}$ & $\begin{array}{c}0.12 \\
(0.72) \\
\end{array}$ \\
\hline B90 Sum: $\beta_{t}+\beta_{t-1}+\beta_{t-2}$ & $\begin{array}{l}-6.74 \\
(4.93)\end{array}$ & $\begin{array}{l}-7.07 \\
(5.12)\end{array}$ & $\begin{array}{l}-6.03 \\
(5.15)\end{array}$ & $\begin{array}{l}-4.28 \\
(5.04)\end{array}$ & $\begin{array}{l}-3.76 \\
(4.27)\end{array}$ & $\begin{array}{l}-6.78 \\
(4.67)\end{array}$ & $\begin{array}{l}-6.51 \\
(5.04)\end{array}$ & $\begin{array}{l}-4.38 \\
(4.62)\end{array}$ & $\begin{array}{l}-6.56 \\
(4.98)\end{array}$ & $\begin{array}{l}-7.57 \\
(4.92)\end{array}$ & $\begin{array}{l}-6.65 \\
(5.00)\end{array}$ & $\begin{array}{l}-3.54 \\
(4.41)\end{array}$ \\
\hline T10 Sum: $\beta_{t}+\beta_{t-1}+\beta_{t-2}$ & $\begin{array}{c}1.67 \\
(1.34)\end{array}$ & $\begin{array}{c}1.75 \\
(1.36)\end{array}$ & $\begin{array}{c}2.01 \\
(1.34)\end{array}$ & $\begin{array}{l}1.48 \\
(1.26)\end{array}$ & $\begin{array}{l}2.13 \\
(1.32)\end{array}$ & $\begin{array}{c}2.16 \\
(1.62)\end{array}$ & $\begin{array}{c}1.63 \\
(1.36)\end{array}$ & $\begin{array}{l}1.80 \\
(1.37)\end{array}$ & $\begin{array}{l}1.65 \\
(1.35)\end{array}$ & $\begin{array}{c}1.56 \\
(1.39)\end{array}$ & $\begin{array}{c}1.63 \\
(1.33)\end{array}$ & $\begin{array}{c}2.37 \\
(1.49)\end{array}$ \\
\hline Bottom - Top: & $\begin{array}{l}-8.41 \\
(5.05)\end{array}$ & $\begin{array}{l}-8.83^{*} \\
(5.18)\end{array}$ & $\begin{array}{l}-8.04 \\
(5.31)\end{array}$ & $\begin{array}{l}-5.76 \\
(5.14)\end{array}$ & $\begin{array}{l}-5.89 \\
(4.59)\end{array}$ & $\begin{array}{l}-8.93^{*} \\
(4.90)\end{array}$ & $\begin{array}{l}-8.15 \\
(5.11)\end{array}$ & $\begin{array}{l}-6.18 \\
(4.84)\end{array}$ & $\begin{array}{l}-8.21 \\
(5.11)\end{array}$ & $\begin{array}{l}-9.13^{*} \\
(4.97)\end{array}$ & $\begin{array}{l}-8.28 \\
(5.12)\end{array}$ & $\begin{array}{l}-5.91 \\
(4.71)\end{array}$ \\
\hline \multicolumn{13}{|c|}{ Panel B: Two-Year Changes } \\
\hline Bottom 90 & $\begin{array}{c}-9.41^{* * *} \\
(3.48)\end{array}$ & $\begin{array}{c}-9.87^{* * *} \\
(3.50)\end{array}$ & $\begin{array}{c}-9.70^{* * *} \\
(3.53)\end{array}$ & $\begin{array}{c}-9.71^{* * *} \\
(3.43)\end{array}$ & $\begin{array}{c}-9.71^{* * *} \\
(3.44)\end{array}$ & $\begin{array}{c}-9.67^{* * *} \\
(3.51)\end{array}$ & $\begin{array}{c}-9.64^{* * *} \\
(3.50)\end{array}$ & $\begin{array}{c}-9.67^{* * *} \\
(3.46)\end{array}$ & $\begin{array}{c}-9.70^{* * *} \\
(3.47)\end{array}$ & $\begin{array}{c}-9.83^{* * *} \\
(3.47)\end{array}$ & $\begin{array}{c}-9.72^{* * *} \\
(3.47)\end{array}$ & $\begin{array}{c}-9.76^{* * *} \\
(3.60)\end{array}$ \\
\hline Top 10 & $\begin{array}{l}1.52^{*} \\
(0.87)\end{array}$ & $\begin{array}{c}1.40 \\
(0.84)\end{array}$ & $\begin{array}{l}1.66^{* *} \\
(0.82)\end{array}$ & $\begin{array}{c}1.38 \\
(0.84)\end{array}$ & $\begin{array}{l}1.44^{*} \\
(0.85)\end{array}$ & $\begin{array}{l}1.47^{*} \\
(0.86)\end{array}$ & $\begin{array}{l}1.44^{*} \\
(0.86)\end{array}$ & $\begin{array}{c}1.39 \\
(0.90)\end{array}$ & $\begin{array}{l}1.44^{*} \\
(0.85)\end{array}$ & $\begin{array}{c}1.39 \\
(0.84)\end{array}$ & $\begin{array}{l}1.44^{*} \\
(0.85)\end{array}$ & $\begin{array}{l}1.55^{*} \\
(0.83)\end{array}$ \\
\hline P-Value (Bottom $90=$ Top 10) & 0.00 & 0.00 & 0.00 & 0.00 & 0.00 & 0.00 & 0.00 & 0.00 & 0.00 & 0.00 & 0.00 & 0.00 \\
\hline \multicolumn{13}{|l|}{ Controls } \\
\hline 1) Government Transfers Per Capita & Y & $\mathrm{N}$ & $\mathrm{N}$ & $\mathrm{N}$ & $\mathrm{N}$ & $\mathrm{N}$ & $\mathrm{N}$ & $\mathrm{N}$ & $\mathrm{N}$ & $\mathrm{N}$ & $\mathrm{N}$ & $\mathrm{N}$ \\
\hline 2) Federal IG Spending Per Capita & $\mathrm{N}$ & Y & $\mathrm{N}$ & $\mathrm{N}$ & $\mathrm{N}$ & $\mathrm{N}$ & $\mathrm{N}$ & $\mathrm{N}$ & $\mathrm{N}$ & $\mathrm{N}$ & $\mathrm{N}$ & $\mathrm{N}$ \\
\hline 3) Minimum Wage & $\mathrm{N}$ & $\mathrm{N}$ & $\mathrm{Y}$ & $\mathrm{N}$ & $\mathrm{N}$ & $\mathrm{N}$ & $\mathrm{N}$ & $\mathrm{N}$ & $\mathrm{N}$ & $\mathrm{N}$ & $\mathrm{N}$ & Y \\
\hline 4) OASDI & $\mathrm{N}$ & $\mathrm{N}$ & $\mathrm{N}$ & $\mathrm{Y}$ & $\mathrm{N}$ & $\mathrm{N}$ & $\mathrm{N}$ & $\mathrm{N}$ & $\mathrm{N}$ & $\mathrm{N}$ & $\mathrm{N}$ & Y \\
\hline 5) Supplemental Security Income & $\mathrm{N}$ & $\mathrm{N}$ & $\mathrm{N}$ & $\mathrm{N}$ & Y & $\mathrm{N}$ & $\mathrm{N}$ & $\mathrm{N}$ & $\mathrm{N}$ & $\mathrm{N}$ & $\mathrm{N}$ & Y \\
\hline 6) Max SNAP Benefits & $\mathrm{N}$ & $\mathrm{N}$ & $\mathrm{N}$ & $\mathrm{N}$ & $\mathrm{N}$ & Y & $\mathrm{N}$ & $\mathrm{N}$ & $\mathrm{N}$ & $\mathrm{N}$ & $\mathrm{N}$ & Y \\
\hline 7) Medicaid Benefits & $\mathrm{N}$ & $\mathrm{N}$ & $\mathrm{N}$ & $\mathrm{N}$ & $\mathrm{N}$ & $\mathrm{N}$ & Y & $\mathrm{N}$ & $\mathrm{N}$ & $\mathrm{N}$ & $\mathrm{N}$ & Y \\
\hline 8) AFDC + TANF Benefits & $\mathrm{N}$ & $\mathrm{N}$ & $\mathrm{N}$ & $\mathrm{N}$ & $\mathrm{N}$ & $\mathrm{N}$ & $\mathrm{N}$ & $\mathrm{Y}$ & $\mathrm{N}$ & $\mathrm{N}$ & $\mathrm{N}$ & Y \\
\hline 9) Mechanical Change in AFDC \& TANF & $\mathrm{N}$ & $\mathrm{N}$ & $\mathrm{N}$ & $\mathrm{N}$ & $\mathrm{N}$ & $\mathrm{N}$ & $\mathrm{N}$ & $\mathrm{N}$ & Y & $\mathrm{N}$ & $\mathrm{N}$ & Y \\
\hline 10) Mechanical Change in SNAP \& SSI & $\mathrm{N}$ & $\mathrm{N}$ & $\mathrm{N}$ & $\mathrm{N}$ & $\mathrm{N}$ & $\mathrm{N}$ & $\mathrm{N}$ & $\mathrm{N}$ & $\mathrm{N}$ & Y & $\mathrm{N}$ & Y \\
\hline 11) Mechanical Change in Medicaid & $\mathrm{N}$ & $\mathrm{N}$ & $\mathrm{N}$ & $\mathrm{N}$ & $\mathrm{N}$ & $\mathrm{N}$ & $\mathrm{N}$ & $\mathrm{N}$ & $\mathrm{N}$ & $\mathrm{N}$ & $\mathrm{Y}$ & $\mathrm{Y}$ \\
\hline
\end{tabular}

Notes: This table presents analogous results to Table 3 for real state GDP using the ACCRA price index $P_{s, t}^{A C C R A}$. Columns 1 and 2 control for total state transfers per capita and total federal transfers to a state per capita, respectively. Column 3 controls for the minimum wage. Columns 4-11 control for the following as a share of state GDP: OASDI payments, Supplemental Security Income payments, SNAP benefits (assuming max allotment per recipient), Medicaid vendor payments, AFDC and TANF payments, mechanical changes in AFDC and TANF spending, mechanical changes in SNAP and SSI spending, mechanical changes in Medicaid spending. See sections A.2, A.3, and C for more details on these controls and on the microsimulation-model based mechanical changes. Standard errors are clustered by state $\left({ }^{* * *} \mathrm{p}<0.01,{ }^{* *} \mathrm{p}<0.05,{ }^{*} \mathrm{p}<0.1\right)$. The sample period is $1980-2007$. 